\title{
관광산업특수분류 개정안에 기초한 관광산업통계 생산방안 연구
}

권태일 



\section{관광산업특수분류 개정안에 기초한 관광산업통계 생산방안 연구}

Production Plan Study of Tourism Industry Statistics Based on the Revised Special Classification of Tourism Industry

권태일 

연구책임

권태일 한국문화관광연구원 연구위원 

관광산업특수분류 개정안에 기초한 관광산업통계 생산방안 연구

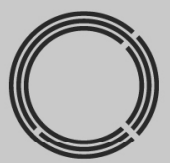

연구개요 



\section{1. 서론}

\section{1. 연구 배경 및 목적}

\section{가. 연구배경}

- 관광정책을 수립하기 위한 기초조사에 해당하는 관광사업체조사의 조사모집단 은 관광진흥법에 등록·허가·신고·지정되어 있는 사업체만을 대상으로 선정되어 있어 관광산업을 대표하지 못하는 한계점

- 관광의 활동과 범위가 확대되어지고 관광산업과 타산업간의 경계가 모호해짐을 반영하여 보다 포괄적 개념의 관광산업을 정의하고 최근 트렌드를 반영한 관광 산업특수분류 개정안에 기초한 조사방안 마련이 필요

\section{나. 연구목적}

- '관광산업특수분류' 3 차 개정(안) 도출

- '관광산업특수분류'를 적용한 단계별 조사모집단 도출

- '관광산업특수분류'를 적용한 관광산업통계 조사방안 마련

\section{2. 연구 범위 및 연구 방법}

- 대상적 범위

- 본 연구의 대상적 범위는 10차 한국표준산업분류(Korean Standard Industrial Classification, KSIC)'로 설정함

- 시간적 범위

- 본 연구 수행을 위한 시간적 범위는 가용 가능한 검토자료 생산 시기를 기준으 로 2018년 기준 제10차 한국표준산업분류, 2018년 기준 전국사업체조사1), 2018년 기준 관광사업체조사로 설정함

1) 국가와 지방자치단체의 정책수립에 필요한 기초자료를 제공하고, 사업체를 조사대상으로 하는 통계조사의 모집단을 제공하는데 있음 
[그림 1] 연구의 대상적 포괄범위

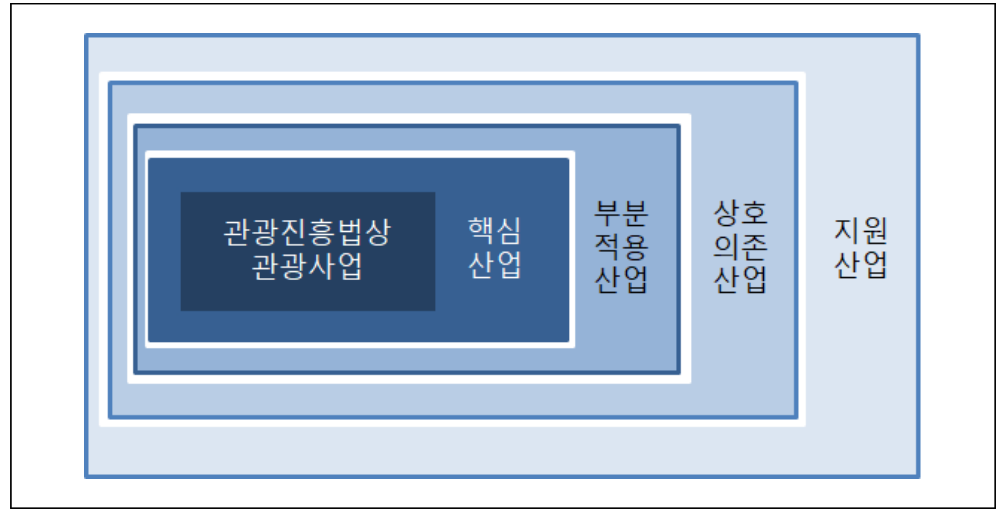

- 내용적 범위

- (관광산업특수분류 개정) 관광산업특수분류 3 차 개정의 경우 기존 2 차 개정 내용 및 한국표준산업분류 10 차 개정의 내용을 반영하여 전문가 델파이 조사 를 통해 개정안 마련 작업을 실시함

- (관광산업통계 생산방안) 관광산업통계 생산방안 마련을 위해 조사모집단을 통계청의『전국사업체조사』 데이터를 바탕으로 주사업과 부사업 중에서 관광 산업과 관광산업특수분류를 하나라도 영위하는 모든 사업체로 정의하고 관광 산업통계를 생산하기 위해 4단계의 설계방안을 제시함

\section{2. 현황분석}

\section{1. 해외사례}

- 본 연구를 위해 해외시례는 관광과 관련된 산업분류와 타 산업의 유사산업분류 를 검토함

- 관광관련 산업분류는 UN의 관광위성계정 관광상품분류, UNWTO의 관광활 동의 국제표준분류를 기준으로 관광상품과 관광활동 차원의 분류체계에 대한 내용을 정리함 
- 타 산업의 유사산업분류는 세계지적재산권기구의 저작권산업분류, 중국의 문 화산업분류, UNWTO의 MICE산업분류를 검토하였으며 이를 통해 관광산업 특수분류의 4 개 대분류(핵심, 상호의존, 부분적용, 지원산업) 체계의 적절성을 확인함

\section{2. 해외사례}

- 본 연구를 위해 국내사례는 관광사업체 조사의 핵심이 되는 관광진흥법상 관광 산업분류와 관광산업특수분류 및 문화체육관광 특수분류와 관련하여 현재 관련 산업통계에 활용되고 있는 저작권산업특수분류, 콘텐츠산업특수분류, 스포츠산 업특수분류에 대해 검토함

\section{3. 시사점}

- 현황 분석을 통해 다음 3가지의 관광산업특수분류를 활용한 관광산업통계 조사 확대 방안을 도출할 수 있다.

- 첫째, 기존의 관광산업특수분류의 4 개 대분류(핵심, 상호의존, 부분적용, 지원 산업)를 유지함

- 둘째, 관광산업특수분류는 관광진흥법상 관광산업분류와 연계될 수 있도록 구축함

- 셋째, 개정된 관광산업특수분류를 기준으로 실제 관광산업통계 조사까지 이어 질 수 있는 세부적인 조사방안을 제시함

\section{3. 관광산업특수분류 개정방안}

\section{1. 관광산업특수분류 개정방향}

- 관광산업특수분류 개정방향은 산업적 관점과 분류체계 관점에서 접근하여 방향 을 설정함 
- 산업적 관점은 기존 관광산업과 관광산업특수분류를 포괄하는 방안으로 설정하고 분류 체계적 관점을 위해 한국표준산업분류와의 연계 및 준용하는 방안을 검토함

\section{2. 관광산업특수분류 개정절차}

- 관광산업특수분류 개정(안)을 도출하기 위해 국내·외 시례분석 결과를 바탕으로 전문가 자문회의(1차)와 전문가 설문조사(2차) 진행을 통해 최종 개정안을 도출함

〈표 1〉 관광산업특수분류 개정 절차

\begin{tabular}{|c|c|c|}
\hline \multicolumn{2}{|r|}{ 구분 } & 내용 \\
\hline \multicolumn{2}{|c|}{ 관광산업특수분류 개정(안) 도출 } & 국내외 사례분석을 통해 관광산업특수분류 1차 개정(안) 도출 \\
\hline \multicolumn{2}{|c|}{ 1차 전문가 자문회의 } & $\begin{array}{l}1 \text { 차 개정(안)을 기준으로 전문가 자문회의 실시 } \\
1 \text { 차 개정(아)을 수ㅈㅓㅓ.보와하 } 2 \text { 차 개정(아) 도축 }\end{array}$ \\
\hline \multirow{4}{*}{$\begin{array}{l}\text { 전문가 } \\
\text { 의견조사 }\end{array}$} & 사전 준비 & 전문가 조사 전문가 패널 선정 \\
\hline & 1차 전문가 조사 & $\begin{array}{l}2 \text { 차 개정(안)을 기준으로 전문가 조사 진행 } \\
2 \text { 차 개정(안)을 수정.보완한 } 3 \text { 차 개정(안) 도출 }\end{array}$ \\
\hline & 2차 전문가 조사 & 3차 개정(안)을 기준으로 전문가 조사 진행 \\
\hline & 타당도 및 신뢰도 검증 & 도출된 분류에 대한 타당도 및 신뢰도 검증 \\
\hline \multicolumn{2}{|c|}{ 2차 전문가 자문회의 } & $\begin{array}{l}\text { 관광산업특수분류 개정(안) 최종 수정·보완 } \\
\text { 통계청과 문화체육관광부 의견 수렴 }\end{array}$ \\
\hline \multicolumn{2}{|c|}{ 관광산업특수분류 개정 } & 최종 관광산업특수분류 개정(안) 도출 및 개정 \\
\hline
\end{tabular}

\section{3. 주요 개정 내용}

- 관광산업특수분류 3 차 개정안은 앞서 제시한 주요 개정내용과 세부 개정 내용을 기준으로 다음과 같이 정리함

- 주요 개정 내용은 (1) 한국표준산업분류( KSIC) 10 차 개정과 (2) 관광진흥법상 관광산업의 신설 및 삭제, (3) 최근의 관광산업 변화에 따른 트렌드를 기준으로 전문가 인터뷰 및 의견조사 내용을 바탕으로 정리함 
〈표 2〉최종 분류체계

\begin{tabular}{|c|c|c|c|c|}
\hline \multicolumn{2}{|c|}{ 세분류 기준 } & 1차 결과 & 2차 결과 & 최종 결과 \\
\hline \multirow{30}{*}{$\begin{array}{l}\text { 핵심 } \\
\text { 관광 } \\
\text { 산업 }\end{array}$} & 면세점 & $\bigcirc$ & $\bigcirc$ & $\begin{array}{l}\text { 핵심산업유지(관광면세점과 } \\
\text { 일반면세점으로 세분류 구분) }\end{array}$ \\
\hline & 외국인전용 관광기념품 판매업 & $\bigcirc$ & $\bigcirc$ & $\begin{array}{c}\text { 핵심산업유지(관광진흥법상 삭제로 인해 } \\
\text { 관광기념품 판매업으로 분류명 변경) }\end{array}$ \\
\hline & 관광 인증 쇼핑업 & $\triangle$ & $\times$ & $\begin{array}{c}\text { 핵심관광산업 제외 부분관광산업으로 } \\
\text { 이동(인증관련 업종) }\end{array}$ \\
\hline & 관광 철도운송업 & $\bigcirc$ & $\bigcirc$ & $\begin{array}{c}\text { 핵심산업유지(KSIC 개정에 따라 철도 } \\
\text { 여객운송업만 포함) }\end{array}$ \\
\hline & 시내순환 관광업a & $\bigcirc$ & $\bigcirc$ & 핵심산업유지 \\
\hline & 전세버스 운송업 & O & $\bigcirc$ & 핵심산업유지 \\
\hline & 관광궤도업a & O & $\bigcirc$ & 핵심산업유지 \\
\hline & 관광 유람선업a & 0 & $\bigcirc$ & 핵심산업유지 \\
\hline & 크루즈업a & $\bigcirc$ & $\bigcirc$ & 핵심산업유지 \\
\hline & 관광 항공 정기운송업 & $\triangle$ & $\bigcirc$ & \multirow{2}{*}{$\begin{array}{c}\text { 핵심산업유지(KSIC 개정에 따라 } \\
\text { 항공여객운송업만 포함) }\end{array}$} \\
\hline & 관광 항공 부정기운송업 & 0 & O & \\
\hline & 관광 호텔업a & ○ & O & 핵심산업유지 \\
\hline & 수상관광 호텔업a & 0 & O & 핵심산업유지 \\
\hline & 한국전통 호텔업a & O & $\bigcirc$ & 핵심산업유지 \\
\hline & 가족 호텔업a & O & O & 핵심산업유지 \\
\hline & 호스텔업a & 0 & $\bigcirc$ & 핵심산업유지 \\
\hline & 휴양콘도미니엄업a & O & O & 핵심산업유지 \\
\hline & 관광 펜션업a & 0 & O & 핵심산업유지 \\
\hline & 산림휴양림업 & O & O & 핵심산업유지 \\
\hline & 게스트하우스 & 0 & $\bigcirc$ & 핵심산업유지 \\
\hline & 레지던스 호텔 & $\bigcirc$ & $\bigcirc$ & 핵심산업유지 \\
\hline & 관광 인증 모텔업 & $\bigcirc$ & $x$ & $\begin{array}{c}\text { 핵심관광산업 제외 부분관광산업으로 } \\
\text { 이동(인증관련 업종) }\end{array}$ \\
\hline & 민박업 & $\triangle$ & $\bigcirc$ & 핵심산업유지 \\
\hline & 외국인 관광 도시민박업a & $\bigcirc$ & O & 핵심산업유지 \\
\hline & 자동차 야영장업a & $\triangle$ & 0 & 핵심산업유지 \\
\hline & 한옥체험업 & 0 & $\bigcirc$ & 핵심산업유지 \\
\hline & 기타 관광 숙박시설 운영업 & O & O & 핵심산업유지 \\
\hline & 관광 식당업a & $\triangle$ & O & 핵심산업유지 \\
\hline & 관광 유흥음식점업a & $\triangle$ & 0 & 핵심산업유지 \\
\hline & 관광 극장유흥업a & $\triangle$ & O & 핵심산업유지 \\
\hline
\end{tabular}




\begin{tabular}{|c|c|c|c|c|}
\hline & 세분류 기준 & 1차 결과 & 2차 결과 & 최종 결과 \\
\hline & 관광 공연장업a & $\triangle$ & $\bigcirc$ & $\begin{array}{c}\text { 핵심산업유지(관광음식점 및 주점업-> } \\
\text { 문화오락 및 레져스모츠 산업 중분류 이동) }\end{array}$ \\
\hline & 외국인전용 유흥음식점업a & $\triangle$ & $\bigcirc$ & 핵심산업유지 \\
\hline & 일반 여행업 & 0 & 0 & \\
\hline & 국외 여행업a & $\bigcirc$ & $\bigcirc$ & $\begin{array}{c}\text { 액심산법뉴시 } \\
\text { (세부르에 국내외 여핵언 추가) }\end{array}$ \\
\hline & 국내 여행업a & $\bigcirc$ & $\bigcirc$ & \\
\hline & 여행보조 및 예약 서비스업 & O & $\bigcirc$ & 핵심산업유지 \\
\hline & 국제회의 기획업a & $\bigcirc$ & O & 핵심산업유지 \\
\hline & 국제회의 시설업 & $\bigcirc$ & $\bigcirc$ & 핵심산업유지 \\
\hline & 박물관 운영업(미술관 포함) & $\triangle$ & $x$ & 핵심산업 제외 \\
\hline & 사적지 관리 운영업 & $\triangle$ & $x$ & 핵심산업 제외 \\
\hline & 식물원, 동물원 운영업 & $\bigcirc$ & $\bigcirc$ & 핵심산업유지 \\
\hline & 자연공원 운영업 & 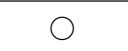 & 0 & 핵심산업유지 \\
\hline & 기타 관광지 운영업 & $\bigcirc$ & $\bigcirc$ & 핵심산업유지 \\
\hline & 종합유원시설업a & $\bigcirc$ & 0 & 핵심산업유지 \\
\hline & 일반유원시설업a & $\bigcirc$ & $\bigcirc$ & 핵심산업유지 \\
\hline & 기타유원시설업a & $\bigcirc$ & $\bigcirc$ & 핵심산업유지 \\
\hline & 농어촌 체험 및 생태 관광업 & O & O & 핵심산업유지 \\
\hline & 관광 공연장업a & O & O & 핵심산업유지 \\
\hline & 경주장 운영업 & $\triangle$ & $x$ & 핵심산업 제외 \\
\hline & 골프장 운영업 & $\triangle$ & $x$ & 핵심산업 제외 \\
\hline & 스키장 운영업 & $\bigcirc$ & $\bigcirc$ & 핵심산업유지 \\
\hline & 낚시장 운영업 & $\triangle$ & $x$ & 핵심산업 제외 \\
\hline & 수상 오락 서비스업 & $\triangle$ & $\bigcirc$ & 핵심산업유지 \\
\hline & 오락 및 관광체험시설 운영 & $\triangle$ & $\bigcirc$ & 핵심산업유지 \\
\hline & 외국인 전용 카지노업a & $\bigcirc$ & $\bigcirc$ & 핵심산업유지 \\
\hline & 내국인 출입 카지노업a & $\bigcirc$ & $\bigcirc$ & 핵심산업유지 \\
\hline & 상업 및 휴양건물 건설업 & $x$ & $x$ & 포함안됨 \\
\hline & 수송시설물 건설업(터미널) & $x$ & $x$ & 포함안됨 \\
\hline & 관광용지 개발조성 공사 & $x$ & $x$ & 포함안됨 \\
\hline $\begin{array}{l}\text { 상호 } \\
\text { 의존 } \\
\text { 과과 }\end{array}$ & $\begin{array}{c}\text { 관광지, 관광단지 또는 관광특구 } \\
\text { 조경 건설업 }\end{array}$ & $x$ & $x$ & 포함안됨 \\
\hline $\begin{array}{l}\text { 난형 } \\
\text { 산업 }\end{array}$ & $\begin{array}{c}\text { 관광 관련 기타 토목시설물 } \\
\text { 건설업 }\end{array}$ & $x$ & $x$ & 포함안됨 \\
\hline & 레저용 의복 소매업 & $x$ & $x$ & 포함안됨 \\
\hline & 레저 및 스포츠용품 소매업 & $x$ & $x$ & 포함안됨 \\
\hline & 자전거 및 기타 운송장비 소매업 & $x$ & $x$ & 포함안됨 \\
\hline
\end{tabular}




\begin{tabular}{|c|c|c|c|c|}
\hline \multicolumn{2}{|c|}{ 세분류 기준 } & \multirow{2}{*}{$\frac{1 \text { 차 결과 }}{x}$} & \multirow{2}{*}{$\begin{array}{c}\text { 2차 결과 } \\
\times\end{array}$} & \multirow{2}{*}{$\begin{array}{l}\text { 최종 결과 } \\
\text { 포함안됨 }\end{array}$} \\
\hline & $\begin{array}{c}\text { 관광용 가방 및 기타 가죽제품 } \\
\text { 소매업 }\end{array}$ & & & \\
\hline & 여행자 보험업 & $\triangle$ & 0 & 핵심산업 포함 \\
\hline & 여행자 수표 발행 & $x$ & $x$ & 포함안됨 \\
\hline & 환전소 & $x$ & $x$ & 포함안됨 \\
\hline & 사진기 및 사진용품 소매업 & $x$ & $x$ & 포함안됨 \\
\hline & 레저장비 임대업 & $\triangle$ & $x$ & 포함안됨 \\
\hline & 운송장비 임대업 & $x$ & $x$ & 포함안됨 \\
\hline & 캠핑카 임대업 & $\triangle$ & $\bigcirc$ & 핵심산업 포함 \\
\hline & 관광용 자동차 임대업 & $\triangle$ & O & 핵심산업 포함 \\
\hline & 일반 자동차 임대업 & $x$ & $x$ & 포함안됨 \\
\hline \multirow{19}{*}{$\begin{array}{l}\text { 부분 } \\
\text { 관광 } \\
\text { 산업 }\end{array}$} & 관광 비인증 쇼핑업 & $x$ & $x$ & 포함안됨 \\
\hline & 도시간 철도 운송업 & $x$ & $x$ & 포함안됨 \\
\hline & 도시내 철도 운송업 & $x$ & $x$ & 포함안됨 \\
\hline & 관광보조 버스 운송업 & $x$ & $x$ & 포함안됨 \\
\hline & 시내외버스 운송업 & $x$ & $x$ & 포함안됨 \\
\hline & 택시 운송업 & $x$ & $x$ & 포함안됨 \\
\hline & 수상운송업 & $x$ & $x$ & 포함안됨 \\
\hline & 내항-내륙 여객선 운송업 & $\times$ & $x$ & 포함안됨 \\
\hline & 청소년수련원 & $x$ & $x$ & 포함안됨 \\
\hline & 관광 비인증 모텔업 & $\times$ & $x$ & 포함안됨 \\
\hline & 관광 일반음식점업 & $x$ & $x$ & 포함안됨 \\
\hline & 비알콜 관광 음료점업 & $x$ & $x$ & 포함안됨 \\
\hline & 기타 관광 주점업 & $x$ & $x$ & 포함안됨 \\
\hline & 일반 공연시설 운영업 & $x$ & $x$ & 포함안됨 \\
\hline & 온라인상 여행정보제공 & $\triangle$ & $\bigcirc$ & 핵심산업 포함 \\
\hline & 관광지도 및 여행서적 출판업 & $\triangle$ & $x$ & 포함안됨 \\
\hline & 통역 서비스업 & $x$ & $x$ & 포함안됨 \\
\hline & 온천탕 & $\times$ & $x$ & 포함안됨 \\
\hline & 그 외 기타 관광서비스업 & $x$ & $x$ & 포함안됨 \\
\hline \multirow{3}{*}{$\begin{array}{l}\text { 신설 } \\
\text { 및 } \\
\text { 분류 } \\
\text { 이동 } \\
\text { 검토 }\end{array}$} & 소형호텔업 & $\bigcirc$ & $\bigcirc$ & $\begin{array}{l}\text { 관광진흥법 신설에 따른 포함 } \\
\text { (관광숙박업 중분류) }\end{array}$ \\
\hline & 의료관광호텔업 & $\bigcirc$ & $\bigcirc$ & $\begin{array}{c}\text { 관광진흥법 신설에 따른 포함 } \\
\text { (관광숙박업 중분류, 현재 운영업체 없음) }\end{array}$ \\
\hline & 일반야영장업 & O & $\bigcirc$ & $\begin{array}{c}\text { 관광진흥법 신설에 따른 } \\
\text { 포함(일반관광숙박업 중분류) }\end{array}$ \\
\hline
\end{tabular}




\begin{tabular}{c|c|c|c|c}
\hline \multicolumn{2}{|c|}{ 세분류 기준 } & 1차 결과 & 2차 결과 & 최종 결과 \\
\hline & 관광사진업 & $\triangle$ & $\bigcirc$ & $\begin{array}{c}\text { 부분관광산업에서->핵심관광산업으로 } \\
\text { 대분류 이동(여행사 및 여행보조 서비스업 } \\
\text { 중분류 포함) }\end{array}$ \\
\cline { 2 - 5 } & 전문휴양업 & $\bigcirc$ & $\bigcirc$ & $\begin{array}{c}\text { 관광진흥법 신설에 따른 포함 } \\
\text { (전문 및 종합휴양업 중분류 신설) }\end{array}$ \\
\cline { 2 - 5 } & 종합휴양업 & $\bigcirc$ & $\bigcirc$ & $\begin{array}{c}\text { 관광진흥법 신설에 따른 포함 } \\
\text { (전문 및 종합휴양업 중분류 신설) }\end{array}$ \\
\hline
\end{tabular}

\section{4. 관광산업통계 생산방안}

\section{1. 관광산업특수분류 모집단 정의}

- 목표모집단은 전국 17 개 지방자치단체의 관광산업과 관광산업특수분류코드 기 준 모든 사업체로 정의함

- 조사모집단은 통계청의『전국사업체조사』결과 중에서 주사업과 부사업 중에서 관광산업과 관광산업특수분류를 하나라도 영위하는 모든 사업체로 정의하고 관 광산업특수분류의 개정안에 따른 관광산업통계를 생산하기 위해 4단계의 조사 모집단을 구성함

[그림 2] 관광산업의 단계별 조사모집단 현황

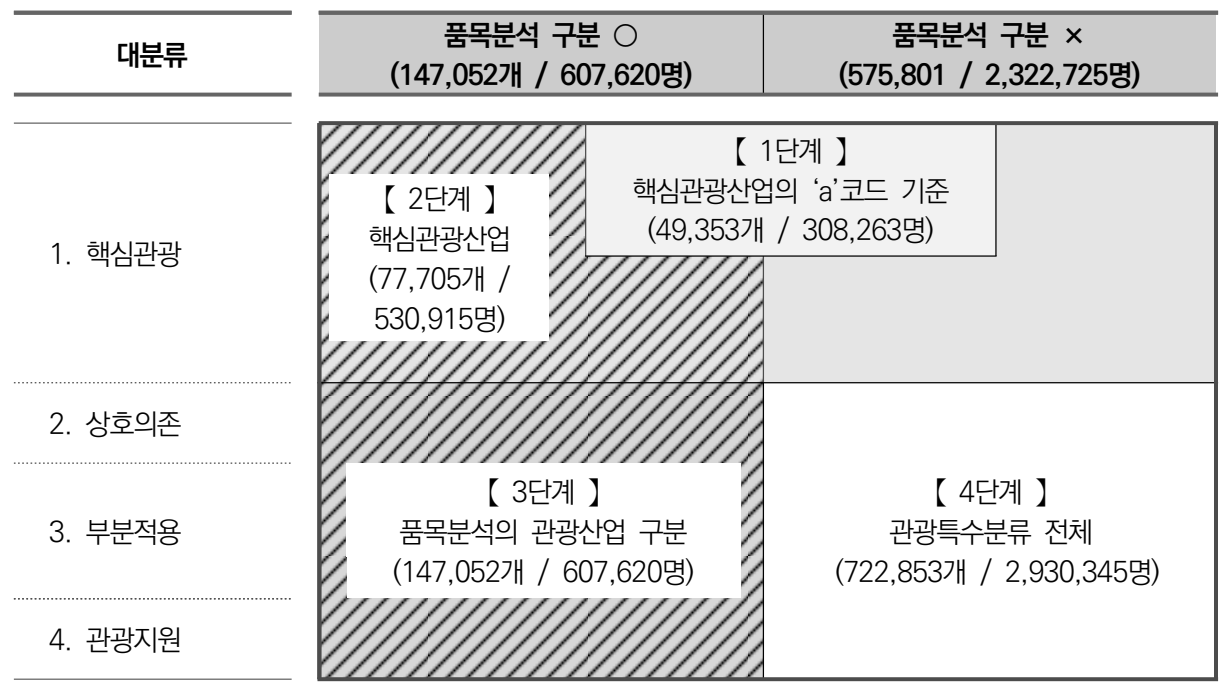




\section{2. 관광산업특수분류 적용 모집단 현황}

- 1 단계: 핵심관광산업의 'a'코드 기준

- 관광산업특수분류 > 핵심관광산업 > 'a' 코드 기준 (단, 부분적용산업의 3 개 사업체 포함) 사업체는 총 49,353 개소이며 관광 음식점 및 주점업이 24,675 개소로 전체의 $50.0 \%$ 를 차지함

- 다음으로 관광숙박업이 23,344개소로 25.01\%를 차지하여 전체의 $75.01 \%$ 를 차지하고 있으며 종사자수의 비중도 전체의 $78.17 \%$ 를 차지함

- 2단계: 핵심관광산업 전체

- 핵심관광산업의 사업체수는 모두 77,705개소이며 핵심관광산업의 'a' 코드 기 준의 사업체 현황과 마찬가지로 관광 음식점 및 주점업과 관광숙박업이 56,284 개소로 $72.43 \%$ 를 차지하고 있음

- 종사자수의 비중은 전체의 $54.11 \%$ 를 차지하고 있는 것으로 나타남

- 3 단계: 품목분석의 관광산업 기준

- 품목분석의 관광산업 기준 전체 사업체는 147,052 개 사업체임

- 핵심 관광산업과 부분적용 관광산업은 137,539 개로 $93.5 \%$ 를 차지하고 있고 종사자수는 565,808명으로 93.1\%를 차지하고 있음

- 상호의존 관광산업과 관광지원산업의 경우 사업체는 각각 8,933 개, 580 개이 고 종사자수는 25,434 명, 16,378 명을 나타내고 있음

- 4단계: 관광산업특수분류 전체 사업체

- 관광산업특수분류로 구분되는 모든 사업체는 총 722,853 개이며 총 종사자수 는 2,930,345명으로 나타남

\section{3. 관광산업특수분류기준 표본설계}

- 본 연구에서는 관광산업특수분류를 기준으로 조사를 위한 표본설계 방안을 제시 하고 표본배분방법론 및 설계된 층별로 조사를 위한 적정표본수를 도출함

- 적정 표본배분방법 도출 및 표본수 산출을 위해 3 가지 주요 표본추출방법론(비례 
배분법, 네이만배분법, 수정절사법)을 활용하여 상대허용오차수준별 시뮬레이션 을 수행하고 필요 표본수는 전수조사 사업체의 응답률을 $90 \%$ 로 가정하여 산출함

[그림 3] 관광산업특수분류기준에 따른 표본설계 절차

\begin{tabular}{|c|c|c|}
\hline 모집단 정의 & $\Rightarrow$ & $\begin{array}{l}\text { - 표본설계의 목표모집단과 조사모집단을 정의 } \\
\text { - 모집단의 가용한 정보수준을 파악 } \\
\text { (사업체 단위의 기준변수 활용, 층별 통계량 활용 가능성) }\end{array}$ \\
\hline \multicolumn{3}{|r|}{ 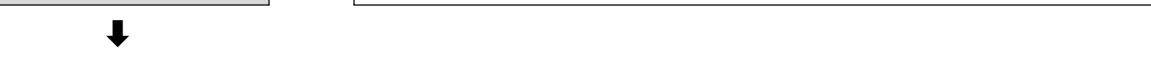 } \\
\hline $\begin{array}{l}\text { 층화여부 밈 } \\
\text { 층화변수 결정 }\end{array}$ & $\Rightarrow$ & $\begin{array}{l}\text { - 객관적인 층별 차이가 예상되는 경우는 층을 정의 } \\
\text { - 너무 세분화된 층은 오히련 표본수를 증가시키게 되어 부적절함 } \\
\text { ※ 단순임의추출 대비 적은 수의 표본이 되는지를 검토해야 함 }\end{array}$ \\
\hline \multicolumn{3}{|l|}{$\downarrow$} \\
\hline $\begin{array}{l}\text { 신뢰수준과 } \\
\text { 목요오차 수준 결정 }\end{array}$ & $\Rightarrow$ & $\begin{array}{l}\text { - 조사의 신뢰수준과 ㅁㅗㅗ표오차 수준을 결정 } \\
\text { - 본 연구에서는 신뢰수준 } 9 \% \text { 에서 목표오차수준을 } \pm 5 \% p \text { 내외 }\end{array}$ \\
\hline \multicolumn{3}{|l|}{$\downarrow$} \\
\hline $\begin{array}{l}\text { 표본배분방법론 } \\
\text { 결엉 }\end{array}$ & $\Rightarrow$ & $\begin{array}{l}\text { - 모집단의 가용 정보와 표본배분방법별 효율성을 고려하여 적정 표본배 } \\
\text { 분방법을 선정 } \\
\text { (예) 동일 목표오차수준에서 표본수가 가장 적거나 총분산이 최소화되 } \\
\text { 는 표본배분방법론 선정(본 연구는 최소 표본수 기준 활용) }\end{array}$ \\
\hline \multicolumn{3}{|l|}{$\downarrow$} \\
\hline $\begin{array}{l}\text { 최종 표본수 } \\
\text { 결정 }\end{array}$ & $\Rightarrow$ & $\begin{array}{l}\text { - ㅅㅓㅓ계된 층별로 최소한의 집계와 통계 산출을 위한 조사 표본수를 배분 } \\
\text { 하여 최종적인 표본수를 산출 }\end{array}$ \\
\hline
\end{tabular}

\section{4. 관광산업특수분류기준 설문 및 관광비 추정방안}

\section{가. 설문 설계}

- 본 연구에서는 기존 관광진흥법상 등록-허가-신고·지정된 사업체를 대상으로 진 행되고 있는 '관광사업체조사(승인번호 제113017호)' 항목을 기초로 하여 관광 산업특수분류 확대로 인해 새롭게 포함되는 신규 업종을 포괄할 수 있는 설문항 목 구성 방안을 중점적으로 검토

- 설문지 구성은 업종별 공통항목과 특수항목을 구분하여 설계하였으며 신규 업종 의 경우 상품판매 관련 업종, 운송 관련 업종, 숙박 관련 업종, 시설 운영 관련 업종, 레저/스포츠 관련 업종, 기타 업종으로 구분하여 구성함 
〈표 3〉 관광산업특수분류체계 기준 관광사업체조사 설문 항목(업종별 특수 항목) 구성안 (1)

\begin{tabular}{|c|c|c|}
\hline 구분 & 업종명(세분류) & 조사 항목 \\
\hline \multirow{34}{*}{$\begin{array}{l}\text { 관광 } \\
\text { 진흥법상 } \\
\text { 포함 업종 }\end{array}$} & 일반 여행업 & 세부 상품 유형별 매출액 \\
\hline & 국외 여행업 & 세부 상품 유형별 구매자 수 \\
\hline & 국내 여행업 & 패키지상품 판매 및 매출액 비중 \\
\hline & 관광 호텔업 & \multirow{8}{*}{$\begin{array}{l}\text { 내외국인별 객실/부대시설 매출액 } \\
\text { 내외국인별 이용객/판매객실 수 } \\
\text { 객실 현황, 근무 교대 주기 }\end{array}$} \\
\hline & 수상관광 호텔업 & \\
\hline & 한국전통 호텔업 & \\
\hline & 가족 호텔업 & \\
\hline & 호스텔업 & \\
\hline & 소형호텔업 & \\
\hline & 의료관광호텔업 & \\
\hline & 크루즈업 & \\
\hline & 휴양콘도미니엄업 & $\begin{array}{l}\text { 회원/비회원별 객실/부대시설 매출액 } \\
\text { 회원/비회원별 이용객/판매객실 수 } \\
\text { 객실 현황, 근무 교대 주기 }\end{array}$ \\
\hline & $\begin{array}{l}\text { 종합휴양업 } \\
\text { 전문휴양업 }\end{array}$ & 세부 유형별 매출액, 연간 이용객 수, 객실현황 \\
\hline & 일반야영장업 & 세부 유형별 매출액, 연간 이용객 수, 시설 유형별 보유 현황 \\
\hline & 관광 유람선업 & 세부 유형별 매출액, 연간 이용객 수, 선박 보유 현황 \\
\hline & 자동차 야영장업 & 세부 유형별 매출액, 연간 이용객 수, 시설 유형별 보유 현황 \\
\hline & 관광공연장업 & 세부 유형별 매출액, 연간 이용객 수 \\
\hline & 외국인 관광 도시민박업 & $\begin{array}{l}\text { 객실 현황, } \mathrm{BED} \text { 당 평균 가격, } \\
\text { 연간 객실 판매 현황, 주택 형태 및 주요 운영 형태 }\end{array}$ \\
\hline & 국제회의 기획업 & 해외/국내업체 계약건수 및 참가업체 수 \\
\hline & 국제회의 시설업 & $\begin{array}{l}\text { 내외국인별 연간 참가자 수 } \\
\text { 회의시설(좌석 수), 전시시설(좌석 수) } \\
\text { 연간개최일, 국제/국내행사 개최건수 및 참가업체 수 }\end{array}$ \\
\hline & 외국인 전용 카지노업 & \multirow{2}{*}{ 세부 유형별 매출액, 연간 이용객 수, 시설현황, 최대 수용력 } \\
\hline & 내국인 전용 카지노업 & \\
\hline & 종합유원시설업 & \multirow{3}{*}{$\begin{array}{l}\text { - 세부 유형별 매출액, 연간 이용객 수 } \\
\text { 유기시설 수, 안전검사 대상 유기시설 수 }\end{array}$} \\
\hline & 일반유원시설업 & \\
\hline & 기타유원시설업 & \\
\hline & 관광 유흥음식점업 & 연간 이용객 수, 수용 가능 좌석 수 \\
\hline & 관광 극장 유흥업 & 연간 이용객 수, 수용 가능 좌석 수 \\
\hline & 외국인전용 유흥음식점업 & 연간 이용객 수, 수용 가능 좌석 수 \\
\hline & 관광식당업 & 연간 이용객 수, 수용 가능 좌석 수 \\
\hline & 시내순환 관광업 & 연간 이용객 수, 수용 가능 좌석 수 \\
\hline & 관광사진업 & 연간 이용객 수 \\
\hline & 관광궤도업 & 연간 이용객 수 \\
\hline & 관광펜션업 & \multirow{2}{*}{$\begin{array}{l}\text { 연간 이용객 수, 객실 현황, 객실당 평균 가격, } \\
\text { 연간 객실 판매 현황 }\end{array}$} \\
\hline & 한옥체험업 & \\
\hline
\end{tabular}


〈표 4〉 관광산업특수분류체계 기준 관광사업체조사 설문 항목(업종별 특수 항목) 구성안 (2)

\begin{tabular}{|c|c|c|}
\hline 구분 & 업종명(세분류) & 조사 항목 \\
\hline \multirow{30}{*}{$\begin{array}{l}\text { 관광 } \\
\text { 진흥법상 } \\
\text { 비포함 업종 }\end{array}$} & 면세점 & \multirow{3}{*}{$\begin{array}{l}\text { 취급 품목, 취급 품목별 제조국, 판매 상품 } \\
\text { 조달 방법, 온라인상 홍보 및 판매 여부, 고객과 거래 시 } \\
\text { 주요 거래수단, 판매 촉진 방법, } \\
\text { 관광사업 운영 관련 지원정책 수요 }\end{array}$} \\
\hline & 관광 인증 쇼핑업 & \\
\hline & 외국인전용 관광기념품 판매업 & \\
\hline & 관광 철도운송업 & \multirow{4}{*}{$\begin{array}{l}\text { 보유 장비 수, 운송구간별 계약 형태(왕복계약/편도계약), } \\
\text { 운송거리, } 1 \text { 회 편도 운송비용, } 1 \text { 회 편도 운송시간 }\end{array}$} \\
\hline & 전세버스 운송업 & \\
\hline & 관광 항공 정기운송업 & \\
\hline & 관광 항공 부정기운송업 & \\
\hline & 산림휴양림업 & \multirow{6}{*}{$\begin{array}{l}\text { 내외국인별 객실/부대시설 매출액 } \\
\text { 내외국인별 이용객/판매객실 수 } \\
\text { 객실 현황, 근무 교대 주기 }\end{array}$} \\
\hline & 게스트하우스 & \\
\hline & 레지던스 호텔 & \\
\hline & 관광 인증 모텔업 & \\
\hline & 민박업 & \\
\hline & 기타 관광 숙박시설 운영업 & \\
\hline & 박물관 운영업 & \multirow{5}{*}{$\begin{array}{l}\text { 소장 자료 수 및 종류, 지정(등록) 문화재 수, } \\
\text { 기획/특별전 개최 횟수, 강좌/체험 프로그램 } \\
\text { 개최 종류 및 횟수 }\end{array}$} \\
\hline & 사적지 관리 운영업 & \\
\hline & 식물원, 동물원 운영업 & \\
\hline & 자연공원 운영업 & \\
\hline & 기타 관광지 운영업 & \\
\hline & 경주장 운영업 & \multirow{7}{*}{$\begin{array}{l}\text { 회원/비회원별 매출액, 이용객 수 } \\
\text { 회원/비회원 기준 이용료, } \\
\text { 이용객 대상 안전교육 실시 현황, } \\
\text { 안전 교육 인력 현황, 시설 안전점검 주기 }\end{array}$} \\
\hline & 골프장 운영업 & \\
\hline & 스키장 운영업 & \\
\hline & 낚시장 운영업 & \\
\hline & 수상 오락 서비스업 & \\
\hline & 오락 및 관광체험시설 운영업 & \\
\hline & 농어촌 체험 및 생태 관광업 & \\
\hline & 여행자 보험업 & $\begin{array}{l}\text { 세부 상품 유형별 매출액 } \\
\text { 세부 상품 유형별 구매자 수 }\end{array}$ \\
\hline & 캠핑카 임대업 & 연간 이용객 수, 캠핑카 보유 현황 \\
\hline & 관광용 자동차 임대업 & 연간 이용객 수, 자동차 보유 현황 \\
\hline & 온라인상 여행정보제공업 & \multirow{2}{*}{$\begin{array}{l}\text { 세부 상품 유형별 매출액 } \\
\text { 세부 상품 유형별 이용자 수 }\end{array}$} \\
\hline & 여행보조 및 예약 서비스업 & \\
\hline
\end{tabular}

xiv 관광산업특수분류 개정안에 기초한 관광산업통계 생산방안 연구 


\section{나. 관광비 추정방안}

- 업종간 관광비 산출 방안(업종 분류 간 중복 데이터 보정)

- 관광산업특수분류체계 기준 업종 2 개를 등록하고 사업활동을 하고 있는 사업 체를 조사할 때 개별 업종 단위 조사(업종별 분리조사)가 이루어지지 않고, 2 개 업종 실적을 합산하여 조사가 되었을 경우 이는 동일한 값이 각 업종별로 2 번 집계되는 것을 의미하며, 시장 규모 추정 시 심각한 오류의 원인(과다추 정)으로 작용

- 특히 복수 업종 등록 형태는 관광산업특수분류체계 기준 업종을 2 개 이상 중 복 등록하는 형태 뿐 만 아니라 관광산업특수분류체계 이외 업종을 중복 등록 한 경우도 상당수 존재하기 때문에 이러한 사업체 조사 시 관광산업특수분류 체계 기준 개별 업종단위 응답값을 확보하기 위한 구체적 방안이 반드시 마련 되어야 함

- 업종별 관광비 산출 방안(관광산업 요소 비중 적용)

- 보다 정확한 관광산업조사를 위해서는 조사 대상 업종별로 과연 관광산업과 얼마나 관련이 있는지에 대해 검토를 하는 것임

- 앞서 기술한 업종간 관광비 산출을 통해 중복 데이터가 보정됨과 동시에 각 업종별로 영위하고 있는 산업활동 중 '관광산업 요소가 차지하고 있는 비중' 이 함께 산출되어야 함

- 이를 위해 본 연구에서는 관광산업특수분류체계 기준 6 개 업종 19,237 개 사 업체(관광 인증 모텔업, 민박업, 게스트하우스, 레지던스호텔, 산림휴양림업, 기타 관광 숙박시설 운영업)에 대한 관광비 추정 시범조사를 실시함

- 이를 통해 향후 관광산업특수분류를 적용한 관광산업 조사시 관광비 산출 (Tourism Ratio)을 위한 조사방안에 및 활용에 대한 근거 마련 


\section{5. 결론}

- 국가 및 지역 차원에서 관광산업의 중요성이 강조되면서 다양한 관광산업 정책 을 적극적으로 추진하고 있지만 정책 대상이 되는 관광산업의 분류 및 범위 등에 대해서는 명확한 기준이 마련되어 있지 않은 상황임

- 이러한 한계를 보완하고자 본 연구에서는 관광환경 변화, 관광진흥법 개정, 한국 표준산업분류 변화 등을 고려한 관광산업특수분류 개정(안) 도출방안을 마련하 고 개정된 관광산업특수분류를 활용한 관광산업통계 생산가능성을 제안함

- 관광산업의 범위가 확장되고 타 산업과의 경계가 모호해 지는 등 앞으로도 관광 산업의 변화는 지속될 것으로 예상됨

- 이러한 변화 등을 고려할 때 관광진흥법에서 규정하고 있는 미시적인 관광산업 보다는 관광산업특수분류를 중심으로 한 거시적 차원의 관광산업의 범위를 설정 하는 것이 바람직할 것으로 판단되며 이를 위해서는 본 연구를 통해 제안된 관광 산업특수분류에 대한 지속적인 보완 및 개선이 뒷받침되어야 할 것임

- 향후 관광산업의 범위가 점점 확장되고 타 산업과의 경계도 모호해지는 현상은 앞으로도 지속될 것으로 전망되며 관광산업특수분류에 포함되는 산업의 범위도 점점 확대될 가능성이 높음

- 이러한 변화는 관광산업이 문화체육관광부 뿐만 아니라 거의 대부분의 정부 부 처 업무 영역과 관련될 가능성이 높기 때문에 앞으로 점점 확대되는 관광산업을 반영한 관광산업특수분류를 보완 및 개정하고 이를 활용한 관광산업 통계를 생 산하기 위한 범 부처차원의 협력체계 구축이 필요할 것임 


\section{목차}

제1장 서론

제1절 연구 배경 및 목적 3

1. 연구 배경 3

2. 연구 목적 6

3. 연구 수행절차 8

제2절 연구 범위 및 방법 9

1. 연구 범위 9

2. 연구 방법 13

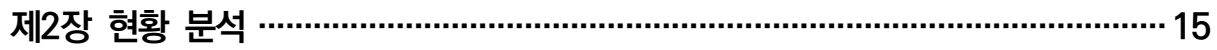

제1절 해외 사례 17

1. 관광산업분류 17

2. 유사 산업분류 23

제2절 국내 사례 27

1. 관광산업분류 $\quad 27$

2. 유사 산업분류 37

3. 관광진흥법상 관광산업분류와 관광산업특수분류 핵심관광산업 비교 $\quad 40$ 제3절 시사점 42

1. 관광산업분류 42

제3장 관광산업특수분류 개정방안 ……............................................................ 45

제1절 관광산업특수분류 개정 방향 $\quad 47$

1. 산업적 관점에서의 개정 방향 47

2. 분류체계 관점에서의 개정 방향 48 
제2절 관광산업특수분류 개정 절차

1. 관광산업특수분류 개정 절차 $\quad 50$

2. 전문가 자문회의 51

3. 전문가 의견조사 $\quad 56$

제3절 관광산업특수분류 개정 내용 65

1. 주요 개정 내용 65

2. 세부 개정 내용 66

3. 기존 분류와 비교 67

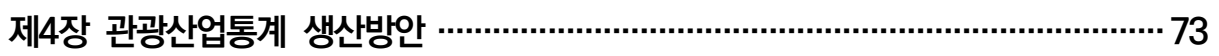

제1절 관광산업특수분류 적용 모집단 구축 75

1. 관광산업특수분류 적용 모집단 정의 75

2. 관광산업특수분류 적용 모집단 현황 78

제2절 관광산업특수분류기준 표본설계 96

1. 표본설계 절차 96

2. 적정 표본크기 결정 97

3. 층화추출법 적용 101

4. 확대전략별 적정 표본수 113

제3절 모수추정방안 제시 116

1. 통계적 추정 116

2. 가중치 118

제4절 관광산업특수분류 기준 설문 설계 및 관광비 추정 방안 122

1. 설문 설계 122

2. 관광비(Tourism Ratio) 추정 방안 133

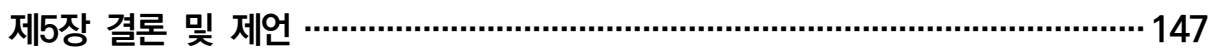

$\begin{array}{ll}\text { 제1절 결론 } & 149\end{array}$

1. 기존 관광산업 분류 및 통계의 한계 149

2. 관광산업특수분류 개정 150

3. 관광산업통계 생산 방안 154 
1. 관광산업 분류 관련 제언

2. 관광산업통계 생산 관련 제언

\section{참고문헌 / 177}

\section{ABSTRACT / 181}

\section{부록 / 183}

【부록】 전문가 의견 조사지 \& 관광요소비중 조사 설문지 / 185 


\section{표 목차}

〈표 1-1〉 Accommodation for visitors(hotel and similar establishments) 4

〈표 1-2〉 관광산업특수분류 포괄영역 5

〈표 1-3〉 산업별 특수분류 현황 6

〈표 1-4〉 한국표준산업분류(10차 개정) 9

〈표 1-5〉시간적 범위 11

〈표 2-1〉 UN의 관광위성계정 관광상품분류 포괄범위 19

〈표 2-2〉 관광위성계정의 핵심 관광 상품에 해당하는 국제표준산업분류(ISIC) 20

〈표 2-3〉 UNWTO 관광활동의 국제표준분류 포괄범위 21

〈표 2-4〉 WIPO의 저작권산업 포괄범위 24

〈표 2-5〉 UNWTO의 회의산업 포괄범위 26

〈표 2-6〉 관광진흥법상 관광산업분류 포괄범위 28

〈표 2-7〉 관광진흥법상 관광사업분류 변화 29

〈표 2-8〉 관광진흥법상 관광산업 규모 31

〈표 2-9〉 관광산업특수분류 포괄범위 33

〈표 2-10〉 관광산업특수분류 변화 34

〈표 2-11〉 관광산업특수분류 핵심관광산업 규모 35

〈표 2-12〉 저작권산업특수분류 포괄범위 38

〈표 2-13〉 콘텐츠산업특수분류 포괄범위 39

〈표 2-14〉 스포츠산업특수분류 포괄범위 40

〈표 2-15〉 관광진흥법상 관광사업분류와 관광산업특수분류 핵심관광산업 비교 41

〈표 2-16〉 국내외 관광, 유사산업 분류별 포괄범위 비교 42

〈표 3-1〉 관광산업특수분류 개정 절차 51

〈표 3-2〉 전문 및 종합휴양업 정의 52

〈표 3-3〉 관광진흥법상 관광산업을 반영한 검토 내용 53

〈표 3-4〉 관광산업관련 한국표준산업분류 10차 개정 내용 54

〈표 3-5〉기타 검토 내용 55

〈표 3-6〉 응답한 패널의 수에 따른 내용타당도 비율(CVR)의 최소값 
〈표 3-7〉 델파이 조사 패널 구성

〈표 3-8〉 핵심산업 대상 1차 전문가 조사 결과 59

〈표 3-9〉상호의존 관광산업 대상 1차 전문가 조사 결과 61

〈표 3-10〉 부분 관광산업 대상 1차 전문가 조사 결과 62

〈표 3-11〉 부분적용 관광산업 대상 1차 전문가 조사 결과 63

〈표 3-12〉 2차 전문가 조사 결과 64

〈표 3-13〉 최종 분류체계 68

〈표 4-1〉 관광산업특수분류 대분류별 세부 분류 현황 75

〈표 4-2〉 관광산업특수분류 대분류별 사업특성별 모집단 현황 76

〈표 4-3〉 기존 관광사업체의 관광산업특수분류별 모집단 현황 78

〈표 4-4〉 핵심관광산업의 'a'코드 기준 중분류 산업별, 규모에 따른 사업체수 현황 79

〈표 4-5〉 핵심관광산업의 'a'코드 기준 중분류 산업별, 규모에 따른 종사자수 현황 79

〈표 4-6〉 핵심관광산업의 관광산업특수분류 모집단 현황 81

〈표 4-7〉 핵심관광산업의 중분류 산업별, 규모에 따른 사업체수 현황 81

〈표 4-8〉 핵심관광산업의 중분류 산업별, 규모에 따른 종사자수 현황 82

〈표 4-9〉 품목분석의 관광산업 기준의 모집단 현황 83

〈표 4-10〉 품목분석의 관광산업 기준 중분류 산업별, 규모에 따른 사업체수 현황 84

〈표 4-11〉 품목분석의 관광산업 기준 중분류 산업별, 규모에 따른 종사자수 현황 86

〈표 4-12〉 품목분석의 관광산업 기준의 평균 종사자수와 변동계수 현황 88

〈표 4-13〉 관광산업특수분류 전체의 모집단 현황 90

〈표 4-14〉 관광산업특수분류 전체의 중분류 산업별, 규모에 따른 사업체수 현황 91

〈표 4-15〉 관광산업특수분류 전체의 중분류 산업별, 규모에 따른 종사자수 현황 92

〈표 4-16〉 관광산업특수분류 전체의 평균 종사자수와 변동계수 현황 95

〈표 4-17〉 1단계(핵심관광산업의 'a'코드 기준)의 규모구분별 표본수 산출 99

〈표 4-18〉 2단계(핵심관광산업)의 규모구분별 표본수 산출 99

〈표 4-19〉3단계(품목분석의 관광산업 구분)의 규모구분별 표본수 산출 100

〈표 4-20〉 4단계(관광산업특수분류 전체)의 규모구분별 표본수 산출 101

〈표 4-21〉 확대전략별 전수조사 대상 선정 103

〈표 4-22〉 층화변수의 적정성 검토 기준 (2단계: 핵심산업 전체) 107

〈표 4-23〉 비례배분법의 층구분별 표본수 현황 (2단계: 핵심산업 전체) 108

〈표 4-24〉 2단계(핵심산업 전체)의 전수조사 응답률에 따른 표본수 변화 109

〈표 4-25〉 층화변수의 적정성 검토 기준 (4단계: 관광산업특수분류 전체) 109

〈표 4-26〉 비례배분법의 층구분별 표본수 현황 (4단계: 관광산업특수분류 전체) 111

〈표 4-27〉 4단계(관광산업특수분류 전체)의 전수조사 응답률에 따른 표본수 변화 111 
〈표 4-28〉 네이만배분법에 의한 적정 표본수 산정 결과

〈표 4-29〉비례배분법에 의한 적정 표본수 산정 결과

〈표 4-30〉 관광산업특수분류 중분류별 품목분석 구분 사업체와 종사자수의 비중 현황 120

〈표 4-31〉 관광산업 식별 비중에 따른 관광산업특수분류 중분류 현황

〈표 4-32〉 기존 관광사업체조사 설문 항목(공통 항목)

〈표 4-33〉 기존 관광사업체조사 설문 항목(업종별 특수 항목)

〈표 4-34〉 관광산업특수분류체계 기준 관광사업체조사 설문 항목(공통 항목) 구성안

〈표 4-35〉 핵심 관광산업 업종 중 관광진흥법상 등록·허가·신고·지정 업종 현황

〈표 4-36〉 핵심 관광산업 업종 중 관광진흥법상 등록·허가·신고·지정되지 않은 업종 현황

〈표 4-37〉 관광산업특수분류체계 기준 관광사업체조사 설문 항목(업종별 특수 항목) 구성안 (1) 131

〈표 4-38〉 관광산업특수분류체계 기준 관광사업체조사 설문 항목(업종별 특수 항목) 구성안 (2) 132

〈표 4-39〉 핵심 관광산업 업종 중 관광진흥법상 포함 업종간 중복등록 사업체 수 133

〈표 4-40〉 핵심 관광산업 부문 관광산업 요소비중 산출을 위한 시범조사 - 기본 설계 136

〈표 4-41〉 핵심 관광산업 부문 관광산업 요소비중 산출을 위한 시범조사 - 설문 내용 136

〈표 4-42〉 업종별 평균 매출액 및 관광활동을 통한 매출액 평균 비중 137

〈표 4-43〉 업종별×지역별 관광활동을 통한 매출액 평균 비중 137

〈표 4-44〉 내/외국인 및 단체/개별 관광객 매출액 비중 138

〈표 4-45〉 업종별 평균 지출액 및 관광활동을 위한 평균 지출액 139

〈표 4-46〉 관광활동 중요성 및 향후 확대 의향 139

〈표 4-47〉 관광산업특수분류 중분류별 관광산업 식별 비중과 변동계수 현황 141

〈표 4-48〉 관광산업특수분류 소분류별 관광산업 식별 비중 현황 142

〈표 5-1〉 관광산업특수분류 개정 절차 152

〈표 5-2〉 관광산업특수분류 상 세부 관광산업 분류 153

〈표 5-3〉 관광산업특수분류 핵심관광산업 3차 개정(안) 154

〈표 5-4〉모집단 사업체 수 현황 156

〈표 5-5〉 관광진흥법 관광사업체 VS 관광산업특수분류 핵심산업 ‘a'코드 157

〈표 5-6〉 네이만배분법에 의한 적정 표본수 산정 결과 158

〈표 5-7〉 통계 생산 등을 위한 기존 통계조사 조정 사례 166

〈표 5-8〉 전국사업체조사 개요 및 관광비 조사 방안 167

〈표 5-9〉서비스업조사 개요 및 관광비 조사 방안 168

〈표 5-10〉외식업체경영실태조사 개요 및 관광비 조사 방안 169

〈표 5-11〉 운수업조사 개요 및 관광비 조사 방안 170

〈표 5-12〉 건설업조사 개요 및 관광비 조사 방안 171

〈표 5-13〉 농림어업조사 개요 및 관광비 조사 방안 172 


\section{그림 목차}

[그림 1-1] 연구 수행절차 8

[그림 1-2] 관광산업통계 생산을 위한 대상적 범위 10

[그림 2-1] 중국의 문화산업분류 포괄범위 25

[그림 3-1] 관광진흥법상의 관광사업과 관광산업특수분류의 관광산업 포괄범위 47

[그림 4-1] 관광산업의 단계별 조사모집단 정의 절차 77

[그림 4-2] 관광산업의 단계별 조사모집단 현황 77

[그림 4-3] 핵심관광산업의 ' $a$ '코드 기준 규모별 사업체수 누적과 종사자수 누적과의 관계 80

[그림 4-4] 핵심관광산업 규모별 사업체수 누적과 종사자수 누적과의 관계 82

[그림 4-5] 관광산업(품목분석) 규모별 사업체수 누적과 종사자수 누적과의 관계 88

[그림 4-6] 관광산업(특수분류) 규모별 사업체수 누적과 종사자수 누적과의 관계 94

[그림 4-7] 관광산업특수분류기준에 따른 표본설계 절차 96

[그림 4-8] 층화기준에 따른 전수표본의 변화 (2단계: 핵심산업) 108

[그림 4-9] 층화기준에 따른 전수표본의 변화 (4단계: 관광산업특수분류 전체) 110

[그림 4-10] (중분류×규모×지역)별 상대오차수준(\%)에 따른 필요 표본수 112

[그림 4-11] 확대전략별 상대오차수준(\%)에 따른 필요 표본수 114

[그림 4-12] 확대전략별 상대오차수준(\%)에 따른 필요 표본수 115

[그림 4-13] 관광사업체조사 시 업종 중복 등록 현황 및 매출액 비중 파악 관련 항목 134

[그림 5-1] 관광산업의 단계별 조사모집단 구성 

관광산업특수분류 개정안에 기초한 관광산업통계 생산방안 연구

제1장

서론 



\section{제1절 연구 배경 및 목적}

\section{1. 연구 배경}

\section{가. 관광산업의 과소추정 문제}

관광정책을 수립하기 위한 기초조사에 해당하는 관광사업체조사의 조사모집단은 관광진흥법에 등록·허가·신고·지정되어 있는 사업체만을 대상으로 선정되어 있어 관 광산업을 대표하지 못하는 한계점이 있다. 통계청의 관광사업체조사 정기품질진단 결 과 현재 모집단 체계로는 관광산업의 규모를 과소 추정할 수 있다는 문제제기와 더불 어 관광산업을 포괄할 수 있는 조사방안 마련이 주요 개선과제로 도출되었다.

\section{「관광사업체조사 정기품질진단 개선 과제」}

※ '10년도 정기통계품질진단 결과 개선 과제

2010. 12. 31. 기준의 등록·허가-신고·지정된 관광사업체 기초통계조사의 조사모집단은 16 개 지자체 에서 제공한 14,281 개 사업체로서 관광진흥법상의 등록업체를 기준으로 한 모집단은 등록시설 위주로 이루어져 관광산업의 실질적인 규모를 과소평가할 수 있음

※ ‘19년도 정기통계품질진단 결과 개선 과제

품질진단 결과 도출한 주요 개선과제로는 통계정보보고서와 통계설명자료 보완, 표본추출방법의 타당성과

\section{나. 관광산업특수분류 체계의 한계}

통계청의 관광사업체조사 확대 개선 의견에도 불구하고 관광산업을 포괄할 수 있 는 관광산업특수분류를 바로 적용하기에는 한계가 있다. 통계청의 관광산업특수분 류는 관광산업의 특성을 반영하고자 마련되었지만, 음식점이나 숙박시설과 같은 경 우 관광과의 직접적인 연관성 여부에 따라 산업의 규모가 판이하게 달라지는 문제 
점을 내포하고 있다. 또한 세부 분류별 품목 예시 및 포괄범위가 적절하게 제시되지 않아 조사모집단으로 활용하는데 한계가 있다.

관광의 활동과 범위가 확대되어지고 관광산업과 타산업간의 경계가 모호해짐을 반영하여 보다 포괄적 개념의 관광산업을 정의하고 최근 트렌드를 반영한 관광산업 특수분류 개정안에 기초한 조사방안 마련이 필요하다.

\section{다. 국제간 비교 가능한 산업분류체계 필요}

나날이 관광산업 범위와 규모가 확장되고 있는 추세에 맞춰 국제관광산업 분류기 준과 호환 가능한 분류체계 마련이 필요하다. 또한 일상적인 관광활동을 포괄적으 로 반영할 수 있는 관광산업 분류체계를 마련해야 할 필요가 있다. 현재 관광사업체 조사로는 국제간 비교 가능한 지표를 도출하기 어려운 상황이며 이로 인해 한국 관 광산업의 수준이 낮게 평가될 수 있기 때문에 TSA 관점에서 국제간 비교 가능한 관광산업분류 체계 마련이 필요하다.

* TSA Table 5: on production accounts of tourism industries

* TSA Table 7: on employment in the tourism industries1)

〈표 1-1〉Accommodation for visitors(hotel and similar establishments)

\begin{tabular}{c|c|c|c}
\hline YOUNTRY & 2010 & 2015 & 2018 \\
\hline CHINA & 13,991 & 10,550 & 8,962 \\
\hline JAPAN & 54,628 & 49,979 & 53,720 \\
\hline KOREA & 688 & 25,334 & $\ldots$ \\
\hline
\end{tabular}

자료: World Tourism Organization (2020), Compendium of Tourism Statistics dataset [Electronic], UNWTO, Madrid, data updated on 20/01/2020.

1) Indicator 12.b.1 "Implementation of standard account tools to monitor the economic and environmental aspects of tourism sustainability”, UNWTO 


\section{라. 관광산업특수분류체계 활용 한계}

관광산업특수분류는 세계관광기구(World Tourism Organization, WTO)와 유 엔통계위원회가 공동으로 작성한 국제관광표준분류(Standard International Classification of Tourism Activities)를 기초로 2000년에 제정되었으며 2차 개 정까지 이루어졌다.2) 관광산업의 과소추정 문제를 해결하고 거시적 차원의 관광산 업을 진단하기 위해 2 차에 걸친 관광산업특수분류체계를 만들었으나 문화체육관광 부 정책지원 대상의 범위를 넘어서는 사업체가 다수 포함되어 있는 문제와 핵심관 광산업 외에 상호의존 관광산업, 부분적용 관광산업, 관광지원산업 등의 경우 실제 관광분야에 기여하는 비율(Tourism Ratio)을 추정하기 어렵기 때문에 관광사업체 조사에는 반영되지 않은 상황이다.

〈표 1-2〉 관광산업특수분류 포괄영역

\begin{tabular}{c|l}
\hline 포괄영역 & \multicolumn{1}{c}{ 정 의 } \\
\hline \multirow{2}{*}{ 핵심 관광산업 } & $\begin{array}{l}\text { 전적으로 관광객에 의존하는 산업으로 주로 관광진흥법에서 규정한 관광산업을 포함 } \\
\text { 한다. }\end{array}$ \\
\hline \multirow{2}{*}{ 상호의존 관광산업 } & $\begin{array}{l}\text { 원래 관광산업은 아니지만 핵심관광산업을 보조하기 위해 동반되는 산업으로 관광 건 } \\
\text { 설업, 관광 및 레저용품 소매업, 관광 금융 및 보험업, 레저장비업을 포함한다. }\end{array}$ \\
\hline \multirow{3}{*}{ 부분적용 관광산업 } & $\begin{array}{l}\text { 부분적으로 관광객에 의존하는 산업으로 관광 비인증 쇼핑업, 부분관광 운송업, 부분 } \\
\text { 관광 숙박업, 부분관광 음식점 및 주점업, 부분관광 공연장업, 부분관광 기타 서비스 } \\
\text { 업을 포함한다. }\end{array}$ \\
\hline 관광 지원산업 & $\begin{array}{l}\text { 관광산업을 지원하기 위한 부문으로 관광관련 관광 연구 개발업, 관광 공공기관, 관광 } \\
\text { 교육서비스업, 관광단체를 포함한다. }\end{array}$ \\
\hline
\end{tabular}

자료: 2016년도 문화체육관광분야 사업체 표본틀 구축

산업특수분류는 관광산업을 포함해 저작권, 콘텐츠, 스포츠 등 4 개의 특수분류가 구축되어 있으며 '콘텐츠실태조사'와 '스포츠실태조사'에서는 현재 특수분류체계를 적용한 조사를 수행하고 있다.

2) 문화체육관광부(2016). 『2016년도 문화체육관광분야 사업체 표본틀 구축』. 


\section{마. 관광산업의 합리적인 규모추정 필요}

한국표준산업분류를 기준으로 2차까지의 관광산업특수분류 개정 작업이 이루어 졌으나 관광사업체조사에는 반영되지 않았기 때문에 거시적 차원의 관광산업에 대 한 규모추정을 도출하기는 어려운 상황이다. TSA 등을 통해 공급차원의 지출액 비 중 등을 산정하고는 있으나 해당 결과 또한 과소 혹은 과대 추정 문제로 대표성 있 게 활용하기는 어려운 상황이다. 이에 2019년 한국표준산업분류(KSIC) 10차 개정 이 이루어진 상황에서 변화된 산업적 특성을 반영한 관광산업특수분류체계 개선하 고 거시적 차원의 관광산업 진단을 위한 조사방안 마련이 필요하다. 관광산업의 규 모추정은 관련 산업의 GDP 기여도 및 고용 기여도3) 등 관련 산업 파급효과 분석에 큰 영향을 주기 때문에 정확한 관광산업 진단을 위한 방안 마련이 필요하다.

〈표 1-3〉 산업별 특수분류 현황

\begin{tabular}{c|c|c|c|c}
\hline 문화체육관광분야 산업분류 & 대분류 & 중분류 & 소분류 & 세분류 \\
\hline 저작권산업특수분류 & 4 & 12 & 56 & 308 \\
\hline 콘텐츠산업특수분류 & 12 & 51 & 139 & - \\
\hline 스푸츠산업특수분류 & 3 & 8 & 20 & 65 \\
\hline 관광산업특수분류 & 4 & 22 & 57 & 106 \\
\hline
\end{tabular}

자료: 2016년도 문화체육관광분야 사업체 표본틀 구축

\section{2. 연구 목적}

\section{가. '관광산업특수분류' 3 차 개정(안) 도출}

통계 자료의 신뢰성과 정확성을 확보하기 위해서는 무엇보다도 통계 생산기준이 합리적으로 설정되어야 하며, 특히 산업의 명확한 진단을 위해서는 해당산업의 특 성을 반영한 모집단 정의 과정이 이루어져야 한다. 관광산업의 경우 기존까지 법적 테두리 내에 포함된 사업체만을 관광산업으로 정의하여 현황파악을 실시하였으나 본 연구에서는 한국표준산업분류 10 차 개정을 기반으로 기존 관광산업특수분류 현 황을 검토하고 관련분야 전문가 의견을 반영하여 보다 현실적인 관광산업특수분류 3) 2019 년 기준 한국 관광산업의 GDP 기여도(총효과)는 $2.8 \%$, 고용기여도(총효과)는 $3.1 \%$ 로 나타남(WTTC) 
개정안을 마련한다. 이를 통해 기존의 미시적 차원의 관광산업에서 포괄적 개념의 관광산업을 정의함과 동시에 문화체육관광부의 정책지원 대상 산업(관광진흥법상 관광사업체)을 별도로 도출할 수 있는 방안을 검토한다.

\section{나. ‘관광산업특수분류’를 적용한 단계별 조사모집단 도출}

관광산업에 대한 포괄범위 및 환경 변화 등을 반영하여 관광산업특수분류 3차 개 정안을 마련하고 통계청의 전국사업체조사 모집단을 바탕으로 조사를 위한 표본틀 4$)$ 을 검토한다. 전국사업체조사 원시자료 구조를 파악하고 관광산업을 정확히 도출하 기 위한 ‘품목분석' 내용을 검토한다. 이를 통해 관광산업특수분류를 적용한 조사가 가능한 단계별 모집단을 도출한다. 다만 표본틀 구축에 활용되는 전국사업체조사의 생산주기가 2년 정도 차이가 나는 만큼 해당 표본틀을 활용하는 국가승인통계 사례 를 검토하여 향후 확대된 관광산업통계 생산에 적용하기 위한 당위성을 검증한다.

\section{다. ‘관광산업특수분류’를 적용한 관광산업통계 조사방안 마련}

본 연구에서는 기존의 관광진흥법상 정의를 통해 조사되어지던 협의의 관광사업 체 조사를 관광산업특수분류체계를 적용한 광의의 조사방안으로 개편함으로써 관 광산업 조사범위를 확대하고자 한다. 기존에 축소 조사되고 있던 관광산업의 범위 를 확대하고 보다 정확한 관광산업의 현황을 파악하기 위해 관광산업특수분류 적용 한 조사방안을 마련하는 것은 매우 의미 있는 작업이다. 그러나 현재 관광사업체조 사를 수행하고 있는 시점에서 관광산업특수분류 개정에 따라 급격하게 조사를 변경 하는 것에는 많은 어려움 및 문제점이 발생할 수 있다. 특히 기존 조사와의 시계열 단절에 따른 문제점, 관광산업특수분류 체계를 적용한 조사에 따른 표본설계 및 모 수추정방안과 더불어 신규업종 추가에 따른 설문문항 도출 및 관광비(Tourism Ratio)적용 방안 등이 면밀히 검토되어야 한다. 또한 조사를 위해 통계청의 전국사 업체조사 모집단을 활용해야 하는 한계에서 기존 조사결과의 시계열적 유지 가능성 에 대한 종합적인 검토를 통해 거시적 차원의 관광산업통계 생산방안을 마련한다.

4) 표본추출단위를 목록(List)화 한 것, 또는 모집단을 구성하는 단위의 목록(List)을 말한다. 추출대장이라고 도 한다. 


\section{3. 연구 수행절차}

본 연구는 크게 I. 서론 - II. 현황분석 -III. 관광산업특수분류 개정방안 - IV. 관광산업통계 생산방안 - V.결론 및 제언으로 총 5단계로 구분하여 연구를 수행할 계획이며, 본 연구의 수행절차는 다음 [그림 1-1]과 같다.

\section{[그림 1-1] 연구 수행절차}

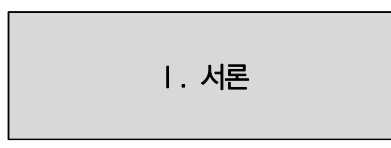

제1절 연구 배경 및 목적

제2절 연구 범위 및 방법

II. 현황분석 $>$\begin{tabular}{l|} 
제1절 해외 사례 \\
제2절 국내 사례 \\
제3절 시사점
\end{tabular}

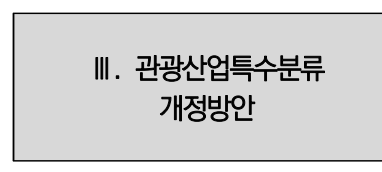

제1절 관광산업특수분류 개정 방향

제2절 관광산업특수분류 개정 절차

제3절 관광산업특수분류 개정 내용

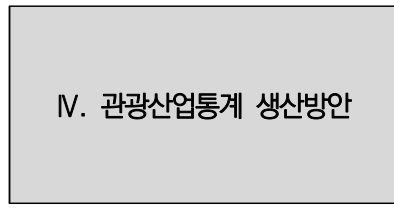

제1절 관광산업특수분류 적용 모집단 구축

제2절 관광산업특수분류기준 표본 설계

제3절 모수추정방안 제시

제4절 관광산업특수분류 기준 설문설계 및 관광비 추정방안

VI. 결론 및 제언 


\section{제2절 연구 범위 및 방법}

\section{1. 연구 범위}

\section{가. 대상적 범위}

본 연구의 대상적 범위는 10차 한국표준산업분류(Korean Standard Industrial Classification, KSIC)5)'로 설정한다. 한국표준산업분류는 생산단위(사업체단위, 기업체단위 등)가 주로 수행하는 산업 활동을 그 유사성에 따라 체계적으로 유형화 한 것이다. 이러한 한국표준산업분류는 산업 활동에 의한 통계 자료의 수집, 제표, 분석 등을 위해서 활동카테고리를 제공하기 위한 것으로 통계법에서는 산업통계 자 료의 정확성, 비교성을 위해 모든 통계작성기관이 이를 의무적으로 사용하도록 규 정하고 있다. 한국표준산업분류는 1963년 제정된 이래 아홉 차례의 개정을 통해 보완.발전되어 왔으며, 이번 10 차 개정은 산업별 대분류 21 개, 중분류 77 개, 소분 류 232 개, 세분류 495 개, 세세분류 1,196 개로 구성되어 있다.

〈표 1-4〉 한국표준산업분류(10차 개정)

\begin{tabular}{l|c|c|c|c}
\hline \multicolumn{1}{|c|}{ 대분류 } & 중분류 & 소분류 & 세분류 & 세세분류 \\
\hline $\mathrm{A}$ 농업, 임업 및 어업 & 3 & 8 & 21 & 34 \\
\hline $\mathrm{B}$ 광업 & 4 & 7 & 10 & 11 \\
\hline $\mathrm{C}$ 제조업 & 25 & 85 & 183 & 477 \\
\hline $\mathrm{D}$ 전기, 가스, 증기 및 수도사업 & 1 & 3 & 5 & 9 \\
\hline $\mathrm{E}$ 하수 · 폐기물 처리, 원료재생 및 환경복원업 & 4 & 6 & 14 & 19 \\
\hline $\mathrm{F}$ 건설업 & 2 & 8 & 15 & 45 \\
\hline $\mathrm{G}$ 도매 및 소매업 & 3 & 20 & 61 & 184 \\
\hline
\end{tabular}

5) 한국표준산업분류(Korean Standard Industrial Classification, KSIC)는 통계법에 의거하여 통계 자료의 정확성 및 국가 간의 비교성을 확보하기 위하여, 유엔에서 권고하고 있는 국제표준산업분류(International Standard Industrial Classification, ISIC)를 기초로 작성한 통계분류이다. 


\begin{tabular}{l|c|c|c|c}
\hline \multicolumn{1}{c|}{ 대분류 } & 중분류 & 소분류 & 세분류 & 세세분류 \\
\hline $\mathrm{H}$ 운수업 & 4 & 11 & 19 & 48 \\
\hline $\mathrm{I}$ 숙박 및 음식점업 & 2 & 4 & 9 & 29 \\
\hline $\mathrm{J}$ 출판, 영상, 방송통신 및 정보서비스업 & 6 & 11 & 24 & 42 \\
\hline $\mathrm{K}$ 금융 및 보험업 & 3 & 8 & 15 & 32 \\
\hline $\mathrm{L}$ 부동산업 및 임대업 & 1 & 2 & 4 & 11 \\
\hline $\mathrm{M}$ 전문, 과학 및 기술 서비스업 & 4 & 14 & 20 & 51 \\
\hline $\mathrm{N}$ 사업시설관리 및 사업지원 서비스업 & 3 & 11 & 22 & 32 \\
\hline $\mathrm{O}$ 공공행정, 국방 및 사회보장 행정 & 1 & 5 & 8 & 25 \\
\hline $\mathrm{P}$ 교육 서비스업 & 1 & 7 & 17 & 33 \\
\hline $\mathrm{Q}$ 보건업 및 사회복지 서비스업 & 2 & 6 & 9 & 25 \\
\hline $\mathrm{R}$ 예술, 스포츠 및 여가관련 서비스업 & 2 & 4 & 17 & 43 \\
\hline $\mathrm{S}$ 협회 및 단체, 수리 및 기타 개인서비스업 & 3 & 8 & 18 & 41 \\
\hline $\mathrm{T}$ 가구내 고용활동 및 달리 분류되지 않은 & 2 & 3 & 3 & 3 \\
$\quad$ 자가소비 생산활동 & 1 & 1 & 1 & 2 \\
\hline $\mathrm{U}$ 국제 및 외국기관 & 77 & 232 & 495 & 1.196 \\
\hline \multicolumn{2}{r}{ 21 } & &
\end{tabular}

[그림 1-2] 관광산업통계 생산을 위한 대상적 범위

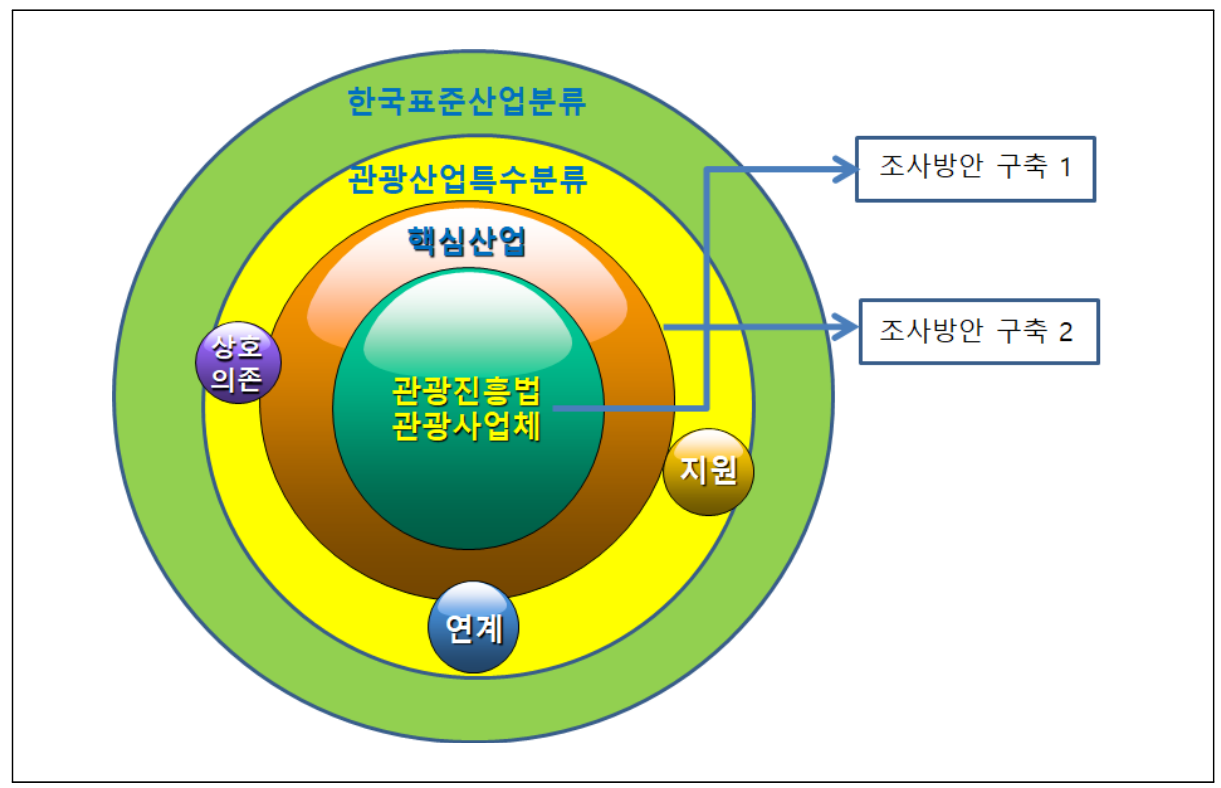




\section{나. 시간적 범위}

본 연구 수행을 위한 시간적 범위는 가용 가능한 검토자료 생산 시기를 기준으로 2018년 기준 제10차 한국표준산업분류, 2018년 기준 전국사업체조사6), 2018년 기준 관광사업체조사로 설정한다.

〈표 1-5〉시간적 범위

\begin{tabular}{c|c|c}
\hline 검토 자료 & 기준연도 & 비고 \\
\hline 한국표준산업분류 & 2018 & 10차 개정 기준 \\
\hline 전국사업체조사 & 2018 & 18년 기준 410만개 \\
\hline 관광사업체조사 & 2018 & 18년 기준 33,452개 \\
\hline
\end{tabular}

\section{다. 내용적 범위}

\section{1) 포괄 범위}

세계적 추세를 반영하고 국제적으로 적용 가능한 분류체계를 위해 여러 국제관광 분류를 참고로 하고 국내산업 실태에 맞게 분류 품목 및 포괄범위를 설정한다.

\section{「국제관광 관련 분류(부록 국내·외 분류 참고)」}

- IRTS(International Recommendations for Tourism Statistics, 2008)

- ISIC Rev. 4.0(International Standard Industrial Classification Revision 4.0)

- CPC Ver. 2(Central Product Classification Version 2

\section{2) 분류 기준}

관광산업특수분류 3차 개정은 수요와 공급측면을 고려한 분류체계를 수립한다. 관광산업을 분류하는데 있어 관광과 관련하여 구입된 모든 재화와 서비스는 관광활 동과 관광지출 목적에 따라 분류하는 것이 용이하기 때문에 관광산업을 주로 수요 측면에서 분류하면서 추가적으로 공급측면(시설)을 고려하고자 한다.

6) 국가와 지방자치단체의 정책수립에 필요한 기초자료를 제공하고, 사업체를 조사대상으로 하는 통계조사의 모집단을 제공하는데 있음 


\section{3) 진행 과정}

관광산업특수분류 개정은 기존의 4 개 영역별(핵심, 상호의존, 부분, 지원) 분류체 계로 작성하며 신규 분류체계 개정을 위해 국내·외 관광산업 분류 자료를 검토하고 진단한다. 검토와 진단 과정에서는 관련분야 전문가 자문회의와 분류체계 구성을 위한 의견조사를 실시한다. 또한 관광산업특수분류와 한국표준산업분류와의 연계방 안을 검토하고 개정 결과의 활용방안을 검토한다.

\section{4) 분류 구조}

분류구조는 기존 체계에서 설정한 1 단계(관광산업의 4개 포괄 영역), 2 단계(3자 리), 3단계(5자리), 4단계(7자리) 구조를 검토하고 핵심 관광산업을 중심으로 관광 산업에 대한 기여도와 역할에 따라 상호의존, 부분적용산업, 지원산업을 재설정하 여 확대된 차원의 관광산업 파급효과 추정 및 국가간 비교 가능한 수준으로 개정한 다. 관광산업특수분류 개정과 더불어 현재 진행하고 있는 관광사업체조사의 연속성 과 지속성을 유지할 수 있는 방안을 검토한다.

\section{5) 조사설계}

조사설계는 관광산업특수분류 개정(안)을 기준으로 단계별 모집단을 설정하고 지 역 $\times$ 산업 $\times$ 사업체 규모(매출액, 일자리 등) 등을 고려한 표본설계 및 조사방식을 검 토한다. 기존 조사업종 외에 신규로 포함된 산업에 대한 설문지 설계 및 관광비 추 정 방안(Tourism Ratio)과 더불어 무응답 대체와 모수추정 방식을 검토한다. 


\section{2. 연구 방법}

\section{$\square$ 문헌조사}

연도별 관광산업분류 및 특수분류체계 연구 검토

$\bigcirc$ 사업체 표본틀 구축 보고서 검토

관광사업체 결과 및 품질개선 컨설팅 자료 검토

\section{$\square$ 자료수집 및 분석}

제 10 차 한국표준산업분류 분석

○ 2018년 기준 관광사업체 조사 분석

\section{$\square$ 전문가 자문}

전문가 자문회의를 통한 체계적인 관광특수분류 개정방안 검토

$\bigcirc$ 관광분야 학계 및 연구분야 전문가를 대상으로 2 회에 걸친 조사를 통해 관광 산업특수분류 3차 개정안 마련

$\bigcirc$ 통계분야 전문가 자문을 통해 표본설계 및 모수추정 방식에 대한 최적방안 도출

\section{현장조사 실시}

○ 3 차 관광산업특수분류 개정과 표본틀 구축 후 관련 산업에 대한 관광비 (Tourism Ratio)산출을 위한 현장 시범조사 실시

$\bigcirc$ 저작권산업 요소비중분석 사례 등 검토를 통해 관광산업특수분류 내에 포함된 일반관광숙박업(관광인증모텔업, 민박업, 게스트하우스, 산림 휴양림업, 레지 던스호텔, 기타관광숙박시설 운영업)에 대한 관광비 산출 가능성 조사 

관광산업특수분류 개정안에 기초한 관광산업통계 생산방안 연구

제2장 현황 분석 



\section{제1절 해외 사례}

\section{1. 관광산업분류}

관광의 정의는 국가 특성, 연구분야, 연구자 관점 등에 따라 다양하게 이루어지고 있다. 또한 관광산업은 관광객의 형태와 소비 유형에 따라 교통, 숙박, 식·음료, 위 락, 오락, 쇼핑 등 기존 산업과 복잡하게 연계되어 있어 관광산업의 범위와 정의 등 을 산업 기준에 따라 명확하게 규정하기는 어렵다(산업연구원, 2016).

$\mathrm{UN} \cdot \mathrm{UNWTO}$ 의 국제기구에서는 통일된 기준의 관광 경제 활동 및 영향을 파악 하기 위하여 표준화된 정의와 가이드라인을 권고하기 시작하였다. UNWTO는 관광 을 ' 1 년 미만의 기간 동안 일상 생활권을 떠나 여가, 업무, 기타 목적으로 여행을 하거나 머무르는 사람의 활동’ 으로 정의하였으며, ‘Recommendations on Tourism Statistics(1994)」에서는 관광활동의 국제표준분류(Standard International Classification of Tourism Activities; SICTA)를 제시하였다. UN은 「Tourism Satellite Account: Recommended Methodological Framework(2008)」에서 관광분야 전반에 걸친 경제적 크기 및 수요와 공급 측면의 정보를 제공하기 위한 관광위성계정(Tourism Satellite Account; TSA)의 산출 기준으로 관광상품분류 를 제시하고 있다.

본 절에서는 관광산업특수분류의 국제 비교 가능성과 관광위성계정 산출 활용성 등을 고려하여 개별 국가의 관광관련 산업분류보다는 UN·UNWTO의 국제기구에 서 정의하고 있는 관광관련 산업분류를 중심으로 살펴보고자 한다. 


\section{가. $\mathrm{UN}$ 의 관광위성계정 관광상품분류}

유엔통계국(UNSD), 유럽통계청(Eurostat), 경제협력개발기구(OECD), 세계관광 기구(UNWTO)는 관광산업의 규모 산출을 위해 2000년에 관광위성계정의 개념적 인 구조를 처음으로 제시하였으며, 2008년에 권고안(TSA: RMF 2008)을 발표하였 다. 여기서 위성계정이란 명칭에 포함된 ‘위성(Satellite)”이라는 단어가 의미하듯 이, 주계정인 국민계정(National account)에 부속되는 계정으로 국민계정의 틀 속 에서 세부 내용을 반영하기에는 내용이 너무 많거나 구조가 맞지 않는 특정 분야를 집중적으로 분석하기 위하여 작성되는 계정을 의미한다.

관광위성계정 작성의 목적은 방문객의 활동과 관련된 재화와 서비스 수요의 모든 측면을 심층 분석하고, 경제 단위 내에서 이러한 재화와 서비스 공급 부문의 상호 운용관계를 측정하는 한편, 다른 경제 활동과 이러한 공급이 어떻게 상호작용하는 지 설명하는데 있다.

관광위성계정 작성과 관련한 관광상품분류는 IRTS 2008에 기반을 두고 있으며, 크게 관광 소비 상품과 비소비 상품으로 구분하며 관광 소비 상품은 다시 관광 핵심 상품, 관광 연계 상품, 비관광 관련 소비 상품으로 분류된다. 관광 핵심 상품 (Tourism Characteristic Products)은 해당 상품에 대한 관광 지출이 전체 관광 지출에서 상당한 비중을 차지하는 상품(IRTS 2008, 5.10), 관광 연계 상품은 (Tourism Connected Products)은 일반적으로 관광 핵심 상품에는 해당하지 않 지만 넓은 범주에서 관광과 연계되는 상품을 의미한다(IRTS 2008, 5.12).

관광 핵심 상품은 12 개의 범주로 구분되어 있으며, 1 10 범주는 국제적으로 비 교가 가능한 관광 핵심 상품으로 숙박서비스, 음식점서비스, 철도운수서비스, 도로 운수서비스, 수상운수서비스, 항공운수서비스, 운송장비 대여서비스, 여행자와 기 타 예약서비스, 문화서비스, 오락-스포츠서비스로 구분된다, 그리고 11 12 범주는 국가별 특화된 상품 및 서비스가 해당된다. 
〈표 2-1〉 UN의 관광위성계정 관광상품분류 포괄범위

\section{포괄범위}

A. 소비 상품

A.1. 관광 핵심 상품

\begin{tabular}{|c|c|}
\hline \multirow{10}{*}{ 핵심상품 } & 1. 숙박서비스 \\
\hline & 2. 음식점서비스 \\
\hline & 3. 철도운수서비스 \\
\hline & 4. 도로운수서비스 \\
\hline & 5. 수상운수서비스 \\
\hline & 6. 항공운수서비스 \\
\hline & 7. 운송장비 대여서비스 \\
\hline & 8. 여행사와 기타 예약서비스 \\
\hline & 9. 문화서비스 \\
\hline & 10. 오락, 스포츠서비스 \\
\hline \multirow{2}{*}{ 국가 특성상품 } & 11. 국가별 관광 특성 상품 \\
\hline & 12. 국가별 관광 특성 서비스 \\
\hline
\end{tabular}

A.2. 관광 연계 상품

A.3. 비관광 관련 소비 상품

B. 비소비 상품

B.1. 귀중품

자료: UN(2008), Tourism Satellite Account: Recommended Methodological Framework 2008

$\ulcorner$ Methodological Notes to the Tourism Statistics Database(2018)」에서는 관광위성계정의 관광 핵심 상품에 해당하는 국제표준산업분류(International Standard Industrial Classification; ISIC)를 제시하였다. 국가별 관광 특성 상품 에는 면세점, 기념품과 관련된 소매업, 수공예품과 관련된 소매업, 기타 관광 핵심 상품과 관련된 소매업 등이 포함될 수 있으나, 국제표준산업분류에서 직접적으로 연계되는 분류가 없어 구체적인 분류 코드는 제시하고 있지 않다. 
〈표 2-2〉 관광위성계정의 핵심 관광 상품에 해당하는 국제표준산업분류(ISIC)

\begin{tabular}{|c|c|c|}
\hline 관광 & ISIC 코드 & ISIC 분류명 \\
\hline \multirow{5}{*}{ 1. 숙박서비스 } & 5510 & 단기숙박업 \\
\hline & 5520 & 캠핑장 및 레저용 차량 주차장 운영업 \\
\hline & 5590 & 기타 숙박업 \\
\hline & 6810 & 부동산 임대 및 공급업 \\
\hline & 6820 & 계약 및 수수료에 의한 부동산업 \\
\hline \multirow{3}{*}{ 2. 음식점서비스 } & 5610 & 음식점 및 기타 음식서비스 활동 \\
\hline & 5629 & 기타 음식서비스 활동 \\
\hline & 5630 & 음료 서비스 활동 \\
\hline 3. 철도운수서비스 & 4911 & 철도여객운송업 \\
\hline 4. 도로운수서비스 & 4922 & 기타 육상여객운송업 \\
\hline \multirow{2}{*}{ 5. 수상운수서비스 } & 5011 & 해상여객운송업 \\
\hline & 5021 & 내륙수상여객운송업 \\
\hline 6. 항공운수서비스 & 5110 & 여객항공운송업 \\
\hline 7. 운송장비 대여서비스 & 7710 & 자동차의 대여 및 임대 \\
\hline \multirow{3}{*}{ 8. 여행사와 기타 예약서비스 } & 7911 & 자동차 임대 및 리스업 \\
\hline & 7912 & 여행사업 \\
\hline & 7990 & 기타 예약서비스업 \\
\hline \multirow{3}{*}{ 9. 문화서비스 } & 9000 & 연극, 예술, 음악 및 기타 예술 오락서비스업 \\
\hline & 9102 & 박물관 및 사적지 관리 운영업 \\
\hline & 9103 & 동식물원 및 자연공원 운영업 \\
\hline \multirow{6}{*}{ 10. 오락, 스포츠서비스 } & 7721 & 오락 및 스포츠 용품 임대업 \\
\hline & 9200 & 갬블링 \\
\hline & 9311 & 스포츠시설 운영업 \\
\hline & 9319 & 기타 스포츠 활동 \\
\hline & 9321 & 유원지 및 테마파크 운영 \\
\hline & 9329 & 기타 놀이 및 오락 활동 \\
\hline \multirow{4}{*}{ 11. 국가별 관광 특성 상품 } & - & 면세점 \\
\hline & - & 기념품과 관련된 소매업 \\
\hline & - & 수공예품과 관련된 소매업 \\
\hline & - & 기타 관광 핵심 상품과 관련된 소매업 \\
\hline 12. 국가별 관광 특성 서비스 & & \\
\hline
\end{tabular}

자료: UNWTO(2018), Methodological Notes to the Tourism Statistics Database 


\section{나. UNWTO의 관광활동의 국제표준분류}

UNWTO는 관광활동의 국제표준분류(Standard International Classification of Tourism Activities; SICTA)를 작성하여 관광산업에 분류에 참고할 것을 권고 하고 있으며, 우리나라의 관광산업특수분류 2차 개정도 이를 기초로 작성되었다.

SICTA는 국제표준산업분류(ISIC)와 생산물분류(Central Product Classification; $\mathrm{CPC}$ )를 기준으로 작성되었으며, ISIC에서의 연계 코드를 제시하고 있다. 또한 관광 산업을 $\mathrm{T} / \mathrm{P}$ 로 구분하고 있는데, ' $\mathrm{T}$ '(Tourism Designation)는 핵심 관광산업, 'P'(Part Involvement in Tourism Field)는 부분 관광산업을 나타낸다.

SICTA에서 관광산업의 포괄범위는 ISIC 대분류 기준으로는 건설업, 소매업, 숙 박 및 음식점업, 운송업, 금융 및 보험업, 부동산·임대업 및 전문·기술 서비스업, 공공행정, 교육기관, 여가 및 개인 서비스업이 해당된다.

〈표 2-3〉 UNWTO 관광활동의 국제표준분류 포괄범위

\begin{tabular}{c|c|c|l}
\hline ISIC 대분류 & 분류 코드 & 구분 & \multicolumn{1}{|c}{ 분류명 } \\
\hline \multirow{5}{*}{ 건설업 } & $4500-1$ & $T$ & 산업용 건물 건설업(호텔, 소매업 등) \\
\cline { 2 - 5 } & $4500-2$ & $T$ & 레크리에이션 시설 건설업(스키장, 골프장 등) \\
\cline { 2 - 5 } & $4500-3$ & $T$ & 토목 건설업 \\
\cline { 2 - 5 } & $4500-4$ & $T$ & 리조트 거주지 건설업(세컨드 하우스, 주말 주택 등) \\
\hline \multirow{5}{*}{} & 5010 & $P$ & 자동차 판매업 \\
\cline { 2 - 5 } & 5020 & $P$ & 자동차 유지 보수업 \\
\cline { 2 - 5 } & 5030 & $P$ & 자동차 부품 판매업 \\
\cline { 2 - 5 } & 5040 & $P$ & 모터사이클 및 관련 부품의 판매 및 유지보수업 \\
\cline { 2 - 5 } & 5050 & $P$ & 연료 소매업 \\
\cline { 2 - 5 } & 5211 & $P$ & 식료품 전문 소매업 \\
\cline { 2 - 5 } & 5219 & $P$ & 기타 비전문 소매업 \\
\cline { 2 - 5 } & 5220 & $P$ & 식료품 소매업 \\
\cline { 2 - 5 } & 5231 & $P$ & 의약품 소매업 \\
\cline { 2 - 5 } & 5232 & $P$ & 섬유, 의복 신발, 가죽 제품 소매업 \\
\cline { 2 - 5 } & 5239 & $P$ & 기타 전문 소매업 \\
\cline { 2 - 5 } & 5240 & $P$ & 중고 상품 소매업 \\
\cline { 2 - 5 } & 5252 & $P$ & 노점 소매업 \\
\hline
\end{tabular}




\begin{tabular}{|c|c|c|c|}
\hline ISIC 대분류 & 분류 코드 & 구분 & 분류명 \\
\hline \multirow{2}{*}{$\begin{array}{l}\text { 숙박 및 } \\
\text { 음식점업 }\end{array}$} & 5510 & T & 숙박업 \\
\hline & 5520 & P & 음식점업 \\
\hline \multirow{9}{*}{ 운송업 } & 6010 & $\mathrm{P}$ & 철도 여객 운송업 \\
\hline & 6021 & $P$ & 정기 육상 여객 운송업 \\
\hline & 6022 & $P$ & 부정기 육상 여객 운송업 \\
\hline & 6110 & $\mathrm{P}$ & 외항 여객 운송업 \\
\hline & 6120 & $P$ & 내항 여객 운송업 \\
\hline & 6210 & T & 정기 항공 운송업 \\
\hline & 6220 & T & 비정기 항공 운송업 \\
\hline & 6303 & $P$ & 운수 보조서비스업 \\
\hline & 6304 & $\mathrm{~T}$ & 기타 운수관련 서비스업 \\
\hline \multirow{4}{*}{$\begin{array}{l}\text { 금융 및 } \\
\text { 보험업 }\end{array}$} & 6519 & $P$ & 기타 금융 중개업 \\
\hline & 6592 & $P$ & 기타 여신 금융업 \\
\hline & 6601 & $P$ & 생명 보험업 \\
\hline & 6603 & $P$ & 비생명 보험업 \\
\hline \multirow{10}{*}{$\begin{array}{c}\text { 부동산, } \\
\text { 임대업 및 } \\
\text { 전문, 기술 } \\
\text { 서비스업 }\end{array}$} & 7030 & $\mathrm{P}$ & 부동산업 \\
\hline & 7111 & $P$ & 운송장비 임대업 \\
\hline & 7130 & $P$ & 개인 및 가정용품 임대업 \\
\hline & 7320 & $P$ & 인문 및 사회과학 연구개발업 \\
\hline & 7413 & $P$ & 시장조사 및 여론조사업 \\
\hline & 7414 & $P$ & 경영 컨설팅업 \\
\hline & 7421 & $P$ & 건축 및 엔지니어링 \\
\hline & 7430 & $P$ & 광고업 \\
\hline & 7494 & $P$ & 사진처리업 \\
\hline & 7499 & $\mathrm{P}$ & 기타 전문, 기술 서비스업 \\
\hline \multirow{5}{*}{ 공공행정 } & 7511 & $P$ & 일반 공공 행정 \\
\hline & 7512 & $P$ & 사회 서비스 행정 \\
\hline & 7513 & $\mathrm{P}$ & 사회 서비스 관리 행정 \\
\hline & 7521 & $\mathrm{P}$ & 외무 행정 \\
\hline & 7523 & $P$ & 공공 질서 행정 \\
\hline \multirow{2}{*}{ 교육기관 } & 8030 & $\mathrm{P}$ & 고등 교육기관 \\
\hline & 8090 & $\mathrm{P}$ & 일반 교육기관 \\
\hline
\end{tabular}




\begin{tabular}{c|c|c|l}
\hline ISIC 대분류 & 분류 코드 & 구분 & \multicolumn{1}{|c}{ 분류명 } \\
\hline \multirow{5}{*}{} & 9111 & $\mathrm{P}$ & 산업 단체 \\
\cline { 2 - 5 } & 9112 & $\mathrm{P}$ & 전문가 단체 \\
\cline { 2 - 5 } & 9120 & $\mathrm{P}$ & 노동조합 \\
\cline { 2 - 5 } & 9199 & $\mathrm{P}$ & 기타 협회 및 단체 \\
\cline { 2 - 5 } & 9212 & $\mathrm{P}$ & 영화 상영 \\
\cline { 2 - 5 } & 9213 & $\mathrm{P}$ & 라디오, 텔레비전 활동 \\
\cline { 2 - 5 } & 9214 & $\mathrm{P}$ & 창작 및 예술관련 서비스업 \\
\cline { 2 - 5 } & 9215 & $\mathrm{P}$ & 티켓 판매업 \\
\cline { 2 - 5 } & 9219 & $\mathrm{P}$ & 기타 창작 및 예술관련 서비스업 \\
\cline { 2 - 5 } & 9231 & $\mathrm{P}$ & 도서관 및 기록보존소 운영업 \\
\cline { 2 - 5 } & 9232 & $\mathrm{P}$ & 박물관 및 사적지 관리 운영업 \\
\cline { 2 - 5 } & 9233 & $\mathrm{P}$ & 식물원, 동물원 및 자연공원 운영업 \\
\cline { 2 - 5 } & 9241 & $\mathrm{P}$ & 스포츠 서비스업 \\
\cline { 2 - 4 } & 9249 & $\mathrm{P}$ & 기타 유사 여가관련 서비스업 \\
\hline
\end{tabular}

자료: UNWTO(1994), Recommendations on Tourism Statistics

주: 구분의 ' $T$ ' 관광산업, 'P'는 부분 관광사업을 의미함

\section{2. 유사 산업분류}

본 절에서는 관광산업특수분류의 4 개 대분류(핵심, 상호의존, 부분적용, 지원산 업) 체계의 적절성을 검토하기 위해 경제적 기여도, 파급효과 측면을 고려하여 산업 분류체계를 구축하고 있는 해외의 유사 산업분류를 중심으로 살펴보고자 한다.

\section{가. 세계지적재산권기구의 저작권산업분류}

세계지식재산권기구(World Intellectual Property Organization; WIPO)는 일관성 있는 통계 산출과 국제적 비교를 위해 2003년 '저작권기반산업의 경제적기 여도 조사 가이드'를 발표하였으며, 현재 45 개국 이상의 국가에서 이를 근거로 저 작권산업 경제적 기여도 조사를 진행하고 있다.

가이드에서는 저작권산업을 창작물 및 보호대상물(소설, 시, 음악, 미술, 지도, 설 계도안, 영화, 소프트웨어 등)의 창작, 생산, 공연, 방송, 전시 또는 도소매 활동을 영 
위하는 산업과 저작권이 그 산업의 수립에 중요한 역할을 하는 산업으로 정의한다.

저작권산업은 저작물에 의존하는 정도에 따라 핵심 저작권산업, 상호의존 저작권 산업, 부분적용 저작권산업, 저작권 지원산업으로 구분하고, 이를 기준으로 GDP 기여도, 고용 등의 주요 지표를 산출하도록 하고 있다. 핵심 저작권산업은 정의상 저작권에 '전적으로' 의존하는 산업으로 저작권산업 경제 기여도 산출시 저작권 요 소를 $100 \%$ 로 적용한다. 상호의존 저작권산업은 '주로' 저작권과 관련 있는 산업, 부분적용 저작권산업은 '일부’가 저작권과 관련 있는 산업, 저작권 지원산업은 핵심 저작권산업에 포함되지 않는 경제 활동을 하는 산업 가운데 작품 및 기타 저작권의 보호 대상이 되는 산출물의 전송과 배포에 관련된 산업으로 4 개의 대분류 중에서 가장 저작권과 관련성이 낮은 산업을 의미한다(한국저작권위원회, 2018).

〈표 2-4〉 WIPO의 저작권산업 포괄범위

\begin{tabular}{|c|c|}
\hline 구분 & 포괄범위 \\
\hline $\begin{array}{l}\text { 핵심 저작권산업 } \\
\text { (Core Copyright Industry) }\end{array}$ & $\begin{array}{l}\text { 작품 및 기타 보호대상물의 창작, 생산, 제조, 공연, 방송, 통신 및 전시, } \\
\text { 혹은 유통 및 판매에 전적으로 종사하는 산업을 의미함 }\end{array}$ \\
\hline $\begin{array}{l}\text { 상호의존 저작권산업 } \\
\text { (Inter-Dependent } \\
\text { Copyright Industry) }\end{array}$ & $\begin{array}{l}\text { 그 기능이 전적으로 혹은 주로 저작물의 창조 생산 및 사용을 가능하게 하는 } \\
\text { 기기의 생산, 제조, 판매에 종사하는 산업을 의미함 }\end{array}$ \\
\hline $\begin{array}{c}\text { 부분적용 저작권산업 } \\
\text { (Partial Copyright Industry) }\end{array}$ & $\begin{array}{l}\text { 부분적으로 저작물의 창조, 생산, 제조, 수행, 방송, 통신과 전시 및 유통 } \\
\text { 판매에 관여하는 산업을 의미함 }\end{array}$ \\
\hline $\begin{array}{c}\text { 저작권 지원산업 } \\
\text { (Non-Dedicated Support } \\
\text { Copyright Industry) }\end{array}$ & $\begin{array}{l}\text { 내부의 부분적인 활동이 저작권 및 관련물의 방송, 통신, 판매 및 유통에 } \\
\text { 기여하며 그 활동이 핵심저작권 산업에 해당하지 않는 산업을 의미함 }\end{array}$ \\
\hline
\end{tabular}

자료: WIPO(2003). Guide on Surveying the Economic Contribution of the Copyright-Based Industries

\section{나. 중국의 문화산업분류}

중국은 문화산업을 사회 대중을 위한 문화, 엔터테인먼트 상품과 서비스 제공 활 동을 주체로 하고 이와 관련된 활동을 하는 산업으로 정의하고 있으며, 그 범위에는 문화산업의 주체를 형성하는 문화 상품(도서, 음반영상제품 등), 문화전파 서비스 (라디오, TV, 문화예술 공연, 박물관 등)와 문화 엔터테인먼트(여행 서비스, 실내 오락 서비스, 여가, 체육 엔터테인먼트 서비스 등) 등이 포함된다(한국콘텐츠진흥 원, 2010). 
중국 통계국에서는 문화산업을 '문화 및 관련 산업분류'를 기준으로 콘텐츠의 활 용 정도에 따라 핵심층, 외곽층, 관련층으로 구분한다. 문화산업 핵심층에는 신문 도서물, 음반제품, 전자출판물, 라디오, $\mathrm{TV}$, 영화, 예술공연, 문화공연관, 문물 및 문화보호, 박물관, 도서관, 군중문화서비스, 문화연구, 기타 문화 등이 포함되며, 문 화산업 외곽층은 인터넷, 여행사서비스, 경치유람서비스, 실내오락, 유원지, $\mathrm{PC}$ 방, 문화중개대리, 문화상품대여와 경매, 광고 등이, 문화산업 관련층은 문구, 악기, 완 구, 카세트테이프, CD, 인쇄설비, TV방송설비, 가정용시청설비, 공예품의 생산과 판매 등이 해당된다.

[그림 2-1] 중국의 문화산업분류 포괄범위

핵심층: 신문도서물, 음반제품, 전자출판물, 라디오, TV, 영화, 예술고연, 문화공연관, 문물 및 문화보호, 박물관, 도서관, 군중문화서비스, 문화연구, 기타문화 등

외각층: 인터넷, 여행사서비스, 경치유람서비스, 실내오락, 유원지 $\mathrm{PC}$ 방, 문화중개대리, 문화상품대여와 경매, 광고 등

관련층: 문구, 악기, 카세트테이프, $\mathrm{CD}$, 인쇄설비, TV방송 설비, 가정용시청설비, 공예품의 생산과 판매 등

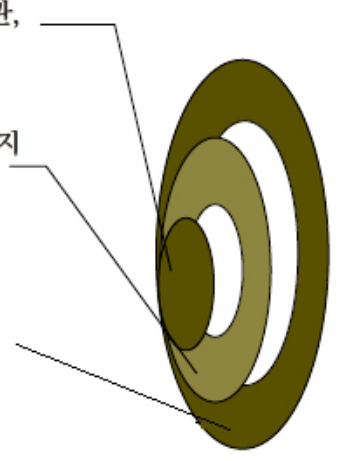

자료: 한국콘텐츠진흥원(2010). 『 중국 문화산업진출 Guidebook」.

\section{다. UNWTO의 MICE산업분류}

UNWTO는 경제 활동 측면을 고려하여 '회의산업(Meetings Industry)'을 분류 하고 있으며, 회의산업을 참가자들에게 동기를 부여하고 사업을 수행하기 위해 한 장소에 많은 사람들이 모이는 것으로 정의하고 있다. 회의에는 콩그레스(congress), 컨벤션(convention), 컨퍼런스(conference), 세미나(seminar) 뿐만 아니라 박람 회, 전시회, 인센티브 활동이 해당된다.

UNWTO는 경제적 기여도 산출 프레임워크를 고려하여 회의산업을 핵심회의산 업(Core Meetings Industry)과 확장회의산업(Extended Approach of the 
Concept of Meetings Industry)으로 구분하고 있다.

핵심회의산업은 전형적으로 회의 관련 서비스를 공급하는 산업으로 전문회의기 획업, 컨벤션/콩그레스/전시 관련 시설업, 인센티브 기획업 및 지역기반 서비스 제 공업, 컨벤션뷰로가 포함된다. 확장회의산업은 핵심회의산업에 포함되지 않지만, 회의 개최 및 참가로 인해 발생하는 수요활동 중심의 경제적 활동으로 숙박업과 함 께 운송업, 기술·설비업, 식음서비스업, 연사중개업, 부스장치업 등이 포함된다.

\section{〈표 2-5〉 UNWTO의 회의산업 포괄범위}

\begin{tabular}{|c|c|}
\hline 구분 & 포괄범위 \\
\hline $\begin{array}{c}\text { 핵심회의산업 } \\
\text { (Core Meetings } \\
\text { Industry) }\end{array}$ & $\begin{array}{l}\text { - 전문회의기획업(Specialized Meeting Organizers) } \\
\text { - 컨벤션, 콩그레스, 전시회 관련 시설업(Convention Centres, Congress } \\
\text { and Exhibition Halls) } \\
\text { - 인센티브 기획업 및 지역기반서비스 제공업(Incentive Houses and } \\
\text { Destination Management Companies) } \\
\text { - 컨벤션뷰로(Convention and Visitor Bureaux) }\end{array}$ \\
\hline $\begin{array}{l}\text { 확장회의산업 } \\
\text { (Extended Approach } \\
\text { of the Concept of } \\
\text { Meetings Industry) }\end{array}$ & $\begin{array}{l}\text { - 숙박업(Accommodation Services) } \\
\text { - 운송업(Transportation) } \\
\text { - 기술·설비업(Technical Equipment) } \\
\text { - 식음서비스업(Catering, Food and Restaurant Services) } \\
\text { - 연사중개업(Speakers' Representation Services) } \\
\text { - 부스장치업(Stand Construction) } \\
\text { - 지원서비스업(Other Support Services) } \\
\text { - 기타 제반서비스업(Auxiliary Services) }\end{array}$ \\
\hline
\end{tabular}

자료: UNWTO(2008). Global Meeting Initiative Vol 1 


\section{제2절 국내 사례}

\section{1. 관광산업분류}

현재 관광과 관련된 산업분류에는 대표적으로 관광진흥법상 관광산업분류와 관 광산업특수분류가 있다. 한국관광위성계정 등 다양한 연구에서도 관광관련 산업분 류를 활용하고 있으나, 이는 앞서 살펴본 해외 사례의 관광관련 산업분류와 유사하 며 공식적인 분류체계를 활용하지는 못하고 있다. 이에 본 연구에서는 기존에 관광 사업체조사에 적용되어 활용된 미시적 차원의 관광산업분류와 관광산업특수분류를 적용하여 파악 가능한 거시적 차원의 관광산업분류에 대해 살펴보고자 한다.

\section{가. 관광진흥법상 관광산업분류}

관광진흥법은 관광 여건을 조성하고 관광자원을 개발하며 관광산업을 육성하여 관광 진흥에 이바지하는 것을 목적으로 1976년에 제정되었다.

관광진흥법에서는 '관광사업'을 관광객을 위하여 운송·숙박·음식·운동·오락·휴 양 또는 용역을 제공하거나 그 밖에 관광에 딸린 시설을 갖추어 이를 이용하게 하는 업(業)으로 정의하고 있으며, 현재 관광사업체조사나 관광정책 효과 측정 등은 관광 진흥법상 등록·허가·신고·지정되어 있는 관광사업체를 기준으로 이루어지고 있다.

관광진흥법상 관광산업분류는 크게 여행알선업, 관광숙박업, 관광객이용시설업 의 3 개 업종에서 1987 년에 5 개 업종(여행업, 관광숙박업, 관광객이용시설업, 국제 회의용역업, 관광편의시설업), 1994 년에 6개 업종(여행업, 관광숙박업, 관광객이용 시설업, 국제회의용역업, 관광편의시설업, 카지노업)을 거쳐 1999년에 현재의 여행 업, 관광숙박업, 관광객이용시설업, 국제회의업, 카지노업, 유원시설업, 관광편의시 설업의 7 개 업종으로 구성되었다. 
〈표 2-6〉 관광진흥법상 관광산업분류 포괄범위

\begin{tabular}{|c|c|c|}
\hline \multicolumn{2}{|c|}{ 구분 } & 정의 \\
\hline \multicolumn{2}{|c|}{ 여행업 } & $\begin{array}{l}\text { 여행자 또는 운송시설·숙박시설, 그 밖에 여행에 딸리는 시설의 경영자 } \\
\text { 등을 위하여 그 시설 이용 알선이나 계약 체결의 대리, 여행에 관한 안내, } \\
\text { 그 밖의 여행 편의를 제공하는 업 }\end{array}$ \\
\hline \multirow[b]{2}{*}{ 관광숙박업 } & 호텔업 & $\begin{array}{l}\text { 관광객의 숙박에 적합한 시설을 갖추어 이를 관광객에게 제공하거나 숙박 } \\
\text { 에 딸리는 음식·운동·오락·휴양·공연 또는 연수에 적합한 시설 등을 함께 } \\
\text { 갖추어 이를 이용하게 하는 업 }\end{array}$ \\
\hline & $\begin{array}{c}\text { 휴양 } \\
\text { 콘도미니엄업 }\end{array}$ & $\begin{array}{l}\text { 관광객의 숙박과 취사에 적합한 시설을 갖추어 이를 그 시설의 회원이나 } \\
\text { 공유자, 그 밖의 관광객에게 제공하거나 숙박에 딸리는 음식·운동·오락. } \\
\text { 휴양·공연 또는 연수에 적합한 시설 등을 함께 갖추어 이를 이용하게 하 } \\
\text { 는 업 }\end{array}$ \\
\hline \multicolumn{2}{|c|}{ 관광객 이용시설업 } & $\begin{array}{l}\text { 관광객을 위하여 음식·운동·오락·휴양·문화·예술 또는 레저 등에 적합한 } \\
\text { 시설을 갖추어 이를 관광객에게 이용하게 하는 업 }\end{array}$ \\
\hline \multicolumn{2}{|c|}{ 국제회의업 } & $\begin{array}{l}\text { 대규모 관광 수요를 유발하는 국제회의(세미나·토론회·전시회 등을 포함 } \\
\text { 한다. 이하 같다)를 개최할 수 있는 시설을 설치·운영하거나 국제회의의 } \\
\text { 계획·준비·진행 등의 업무를 위탁받아 대행하는 업 }\end{array}$ \\
\hline \multicolumn{2}{|c|}{ 카지노업 } & $\begin{array}{l}\text { 전문 영업장을 갖추고 주사위·트럼프-슬롯머신 등 특정한 기구 등을 이용 } \\
\text { 하여 우연의 결과에 따라 특정인에게 재산상의 이익을 주고 다른 참가자 } \\
\text { 에게 손실을 주는 행위 등을 하는 업 }\end{array}$ \\
\hline \multicolumn{2}{|c|}{ 유원시설업 } & $\begin{array}{l}\text { 유기시설(遊技施設)이나 유기기구(遊技機具)를 갖추어 이를 관광객에게 } \\
\text { 이용하게 하는 업(다른 영업을 경영하면서 관광객의 유치 또는 광고 등을 } \\
\text { 목적으로 유기시설이나 유기기구를 설치하여 이를 이용하게 하는 경우를 } \\
\text { 포함한다) }\end{array}$ \\
\hline \multicolumn{2}{|c|}{ 관광 편의시설업 } & $\begin{array}{l}\text { 제1호부터 제6호까지의 규정에 따른 관광사업 외에 관광 진흥에 이바지 } \\
\text { 할 수 있다고 인정되는 사업이나 시설 등을 운영하는 업 }\end{array}$ \\
\hline
\end{tabular}

자료: 관광진흥법

7개 업종의 세부 업종은 [2013년] 관광숙박업에 소형호텔업, 의료관광호텔업 신 설, [2014년] 관광객이용시설업의 외국인전용 관광기념품판매업 제외, [2015년] 관 광객이용시설업에 일반야영장업 신설, 2016년에 관광편의시설업에 관광면세업 신 설, 관광객편의시설업의 외국인관광 도시민박업이 관광객이용시설업으로 이동, 관 광편의시설업의 시내순환관광업에서 관광순환버스업으로 명칭 변경 등 관광산업 환경변화에 따라 개정되었다.

가장 최근에는 2019년 7월에 관광진흥법이 개정되면서 관광지원서비스업(주로 관광객 또는 관광사업자 등을 위하여 사업이나 시설 등을 운영하는 업으로서 쇼핑 
업, 운수업, 숙박업, 음식점업, 문화·오락·레저스포츠업, 건설업, 자동차임대업 및 교육서비스업 등)이 신설되었다. 최근 급변하는 관광환경 및 트렌드 변화에 따라 이 러한 신규 사업의 등장은 지속적으로 나타날 것으로 판단된다.

〈표 2-7〉 관광진흥법상 관광사업분류 변화

\begin{tabular}{|c|c|c|c|c|c|}
\hline \multicolumn{2}{|c|}{ 구분 } & 2012년 & 2014년 & 2016년 & 2019년 \\
\hline \multirow{3}{*}{\multicolumn{2}{|c|}{ 여행업 }} & 일반여행업 & 일반여행업 & 일반여행업 & 일반여행업 \\
\hline & & 국외여행업 & 국외여행업 & 국외여행업 & 국외여행업 \\
\hline & & 국내여행업 & 국내여행업 & 국내여행업 & 국내여행업 \\
\hline \multirow{8}{*}{$\begin{array}{l}\text { 관광 } \\
\text { 숙박업 }\end{array}$} & \multirow{7}{*}{ 호텔업 } & 관광호텔업 & 관광호텔업 & 관광호텔업 & 관광호텔업 \\
\hline & & - & 수상관광호텔업 & 수상관광호텔업 & 수상관광호텔업 \\
\hline & & 한국전통호텔업 & 한국전통호텔업 & 한국전통호텔업 & 한국전통호텔업 \\
\hline & & 가족호텔업 & 가족호텔업 & 가족호텔업 & 가족호텔업 \\
\hline & & 호스텔업 & 호스텔업 & 호스텔업 & 호스텔업 \\
\hline & & - & 소형호텔업 & 소형호텔업 & 소형호텔업 \\
\hline & & - & 의료관광호텔업 & 의료관광호텔업 & 의료관광호텔업 \\
\hline & $\begin{array}{l}\text { 휴양콘도 } \\
\text { 미니엄업 }\end{array}$ & 휴양콘도미니엄업 & 휴양콘도미니엄업 & 휴양콘도미니엄업 & 휴양콘도미니엄업 \\
\hline \multirow{10}{*}{\multicolumn{2}{|c|}{$\begin{array}{c}\text { 관광객 } \\
\text { 이용시설업 }\end{array}$}} & 전문휴양업 & 전문휴양업 & 전문휴양업 & 전문휴양업 \\
\hline & & 제1종 종합휴양업 & 제1종 종합휴양업 & 제1종 종합휴양업 & 제1종 종합휴양업 \\
\hline & & 제2종 종합휴양업 & 제2종 종합휴양업 & 제2종 종합휴양업 & 제2종 종합휴양업 \\
\hline & & - & - & 일반야영장업 & 일반야영장업 \\
\hline & & 자동차야영장업 & 자동차야영장업 & 자동차야영장업 & 자동차야영장업 \\
\hline & & 관광유람선업 & 관광유람선업 & 관광유람선업 & 일반관광유람선업 \\
\hline & & - & - & - & 크루즈업 \\
\hline & & 관광공연장업 & 관광공연장업 & 관광공연장업 & 관광공연장업 \\
\hline & & $\begin{array}{c}\text { 외국인전용 } \\
\text { 관광기념품판매업 }\end{array}$ & - & - & - \\
\hline & & - & - & $\begin{array}{l}\text { 외국인관광 } \\
\text { 도시민박업 }\end{array}$ & $\begin{array}{l}\text { 외국인관광 } \\
\text { 도시민박업 }\end{array}$ \\
\hline \multirow{2}{*}{\multicolumn{2}{|c|}{ 국제회의업 }} & 국제회의시설업 & 국제회의시설업 & 국제회의시설업 & 국제회의시설업 \\
\hline & & 국제회의기획업 & 국제회의기획업 & 국제회의기획업 & 국제회의기획업 \\
\hline \multicolumn{2}{|c|}{ 카지노업 } & 카지노업 & 카지노업 & 카지노업 & 카지노업 \\
\hline
\end{tabular}




\begin{tabular}{|c|c|c|c|c|}
\hline 구분 & 2012년 & 2014년 & 2016년 & 2019년 \\
\hline \multirow{3}{*}{ 유원시설업 } & 종합유원시설업 & 종합유원시설업 & 종합유원시설업 & 종합유원시설업 \\
\hline & 일반유원시설업 & 일반유원시설업 & 일반유원시설업 & 일반유원시설업 \\
\hline & 기타유원시설업 & 기타유원시설업 & 기타유원시설업 & 기타유원시설업 \\
\hline \multirow{13}{*}{$\begin{array}{c}\text { 관광 } \\
\text { 편의시설업 }\end{array}$} & 관광유흥음식점업 & 관광유흥음식점업 & 관광유흥음식점업 & 관광유흥음식점업 \\
\hline & 관광극장유흥업 & 관광극장유흥업 & 관광극장유흥업 & 관광극장유흥업 \\
\hline & $\begin{array}{c}\text { 외국인전용 } \\
\text { 유흥음식점업 }\end{array}$ & $\begin{array}{c}\text { 외국인전용 } \\
\text { 유흥음식점업 }\end{array}$ & $\begin{array}{c}\text { 외국인전용 } \\
\text { 유흥음식점업 }\end{array}$ & $\begin{array}{l}\text { 외국인전용 } \\
\text { 유흥음식점업 }\end{array}$ \\
\hline & 관광식당업 & 관광식당업 & 관광식당업 & 관광식당업 \\
\hline & 시내순환관광업 & 시내순환관광업 & 관광순환버스업 & 관광순환버스업 \\
\hline & 관광사진업 & 관광사진업 & 관광사진업 & 관광사진업 \\
\hline & $\begin{array}{c}\text { 여객자동차 } \\
\text { 터미널 시설업 }\end{array}$ & $\begin{array}{c}\text { 여객자동차 } \\
\text { 터미널 시설업 }\end{array}$ & $\begin{array}{c}\text { 여객자동차 } \\
\text { 터미널 시설업 }\end{array}$ & $\begin{array}{c}\text { 여객자동차 } \\
\text { 터미널 시설업 }\end{array}$ \\
\hline & 관광펜션업 & 관광펜션업 & 관광펜션업 & 관광펜션업 \\
\hline & 관광궤도업 & 관광궤도업 & 관광궤도업 & 관광궤도업 \\
\hline & 한옥체험업 & 한옥체험업 & 한옥체험업 & 한옥체험업 \\
\hline & $\begin{array}{l}\text { 외국인관광 } \\
\text { 도시민박업 }\end{array}$ & $\begin{array}{l}\text { 외국인관광 } \\
\text { 도시민박업 }\end{array}$ & - & - \\
\hline & - & - & 관광면세업 & 관광면세업 \\
\hline & - & - & - & 관광지원서비스업 \\
\hline
\end{tabular}

자료: 관광진흥법

2018년 12월 31일 기준 관광진흥법에 근거하여 등록·허가·신고·지정된 관광사 업체 수는 33,452개로 이는 통계청 전국 사업체조사의 전체 사업체수인 4,103,172 개의 $0.8 \%$ 를 차지하는 규모이다. 7 개 업종별로 살펴보면, 여행업이 19,039 개 (56.9\%)로 가장 많았으며, 다음으로 관광객이용시설업 4,323개(12.9\%), 관광편의 시설업 4,077개(12.2\%), 유원시설업 3,000개(9.0\%), 관광숙박업 2,110 개(6.3\%), 국제회의업 886개(2.6\%), 카지노업 17 개(0.1\%)의 순이다.

2018년 기준 사업체 수는 2017년(33,089개) 대비 $1.1 \%$ 증가하였으며, 유원시 설업(17.7\%), 관광숙박업(14.5\%), 관광객이용시설업(9.1\%), 관광편의시설업(5.0\%) 은 증가한 반면 여행업은(4.5\%)과 국제회의업(0.4\%)은 감소한 것으로 나타났다. 
〈표 2-8〉 관광진흥법상 관광산업 규모

(단위: 개, \%)

\begin{tabular}{|c|c|c|c|c|c|c|}
\hline & \multirow{2}{*}{\multicolumn{2}{|c|}{ 구분 }} & \multirow{2}{*}{ 2016년 } & \multirow{2}{*}{ 2017년 } & \multicolumn{2}{|c|}{ 2018년 } \\
\hline & & & & & 사업체수 & 비중 \\
\hline \multicolumn{3}{|c|}{ 전체 사업체 } & $3,950,169$ & $4,019,872$ & $4,103,172$ & - \\
\hline \multicolumn{3}{|c|}{ 관광사업체 } & 27,696 & 33,089 & 33,452 & 100.0 \\
\hline \multirow{4}{*}{ 여행업 } & \multicolumn{2}{|c|}{ 일반여행업 } & 4,265 & 5,648 & 5,738 & \multirow{4}{*}{56.9} \\
\hline & \multicolumn{2}{|c|}{ 국외여행업 } & 4,572 & 5,706 & 5,544 & \\
\hline & \multicolumn{2}{|c|}{ 국내여행업 } & 3,000 & 2,812 & 2,640 & \\
\hline & \multicolumn{2}{|c|}{ 국내·외여행업 } & 4,768 & 5,778 & 5,117 & \\
\hline \multirow{8}{*}{ 관광숙박업 } & \multirow{7}{*}{ 호텔업 } & 관광호텔업 & 1,038 & 1,035 & 1,043 & \multirow{8}{*}{6.3} \\
\hline & & 수상관광호텔업 & - & - & - & \\
\hline & & 한국전통호텔업 & 8 & 11 & 9 & \\
\hline & & 가족호텔업 & 119 & 144 & 160 & \\
\hline & & 호스텔업 & 291 & 400 & 638 & \\
\hline & & 소형호텔업 & 10 & 26 & 33 & \\
\hline & & 의료관광호텔업 & - & - & - & \\
\hline & \multicolumn{2}{|c|}{ 휴양콘도미니엄업 } & 250 & 227 & 227 & \\
\hline \multirow{9}{*}{$\begin{array}{c}\text { 관광객 } \\
\text { 이용시설업 }\end{array}$} & \multicolumn{2}{|c|}{ 전문휴양업 } & 53 & 89 & 99 & \multirow{9}{*}{12.9} \\
\hline & \multirow{2}{*}{ 종합휴양업 } & 제1종 종합휴양업 & \multirow{2}{*}{32} & \multirow{2}{*}{38} & \multirow{2}{*}{34} & \\
\hline & & 제2종 종합휴양업 & & & & \\
\hline & \multirow{2}{*}{ 야영장업 } & 일반야영장업 & 1,302 & 1,701 & 1,910 & \\
\hline & & 자동차야영장업 & 297 & 400 & 426 & \\
\hline & \multirow{2}{*}{ 관광유람선업 } & 일반관광유람선업 & \multirow{2}{*}{30} & \multirow{2}{*}{42} & \multirow{2}{*}{48} & \\
\hline & & 크루즈업 & & & & \\
\hline & \multicolumn{2}{|c|}{ 관광공연장업 } & 3 & 5 & 7 & \\
\hline & \multicolumn{2}{|c|}{ 외국인관광도시민박업 } & 1,451 & 1,688 & 1,799 & \\
\hline 그제히이어 & & 회의시설업 & 10 & 13 & 13 & \\
\hline & & 회의기획업 & 690 & 877 & 873 & \\
\hline & 카지노 & & 17 & 17 & 17 & 0.1 \\
\hline & & 꾸원시설업 & 39 & 49 & 49 & \\
\hline 유원시설업 & & 꾸원시설업 & 360 & 434 & 416 & 9.0 \\
\hline & & 무원시설업 & 1,383 & 2,065 & 2,535 & \\
\hline
\end{tabular}




\begin{tabular}{|c|c|c|c|c|c|}
\hline & \multirow{2}{*}{ 구분 } & \multirow{2}{*}{ 2016년 } & \multirow{2}{*}{ 2017년 } & \multicolumn{2}{|c|}{ 2018년 } \\
\hline & & & & 사업체수 & 비중 \\
\hline \multirow{11}{*}{$\begin{array}{c}\text { 관광 } \\
\text { 편의시설업 }\end{array}$} & 관광유흥음식점업 & 10 & 12 & 10 & \multirow{11}{*}{12.2} \\
\hline & 관광극장유흥업 & 94 & 136 & 110 & \\
\hline & 외국인전용 유흥음식점업 & 440 & 446 & 358 & \\
\hline & 관광식당업 & 1,476 & 1,489 & 1,617 & \\
\hline & 관광순환버스업 & 52 & 62 & 58 & \\
\hline & 관광사진업 & 13 & 16 & 17 & \\
\hline & 여객자동차 터미널 시설업 & 2 & 2 & 2 & \\
\hline & 관광펜션업 & 406 & 409 & 564 & \\
\hline & 관광궤도업 & 9 & 13 & 16 & \\
\hline & 한옥체험업 & 1,188 & 1,266 & 1,284 & \\
\hline & 관광면세업 & 18 & 33 & 41 & \\
\hline
\end{tabular}

자료1: 문화체육관광부, 관광사업체 기초통계조사 각년도

자료2: 통계청, 전국 사업체조사 각년도

주: 여행업은 관광진흥법상 국내여행업, 국외여행업, 일반여행업의 3 가지 업종으로 분류·등록되나 다수의 사업체가 국내 여행업과 국외여행업 모두를 등록하고 사업을 영위하고 있는 현실을 고려하여, 관광사업체 기초통계조사에서는 여행 업에 '국내·외여행업'을 추가하여 조사함

\section{나. 관광산업특수분류}

통계청은 한국표준산업분류와 함께 일반적인 산업영역과 차별화 된 특성을 지닌 산업에 적용하기 위해 한국표준산업분류 중 특정 산업에 해당하는 분류를 재구성 (세분, 통합 등)하여 산업특수분류를 별도로 제정하고 있다. 2020년 4월 기준으로 공간정보산업특수분류, 관광산업특수분류, 사회서비스산업특수분류, 스포츠산업특 수분류, 저작권산업특수분류, 콘텐츠산업특수분류 등 17 개 산업특수분류가 활용되 고 있다.

관광산업특수분류는 세계관광기구(UNWTO)와 유엔통계위원회가 공동으로 작성 한 관광활동의 국제표준분류(SICTA)를 기초로 국내 산업의 특성을 반영하여 2000 년에 처음으로 제정되었다.

관광산업특수분류에서 관광산업은 크게 핵심관광산업을 중심으로 관광산업에 대 한 기여도와 역할에 따라 상호의존 관광산업, 부분적용 관광산업, 관광지원산업으 로 구분한다. 핵심관광산업은 전적으로 관광객에 의존하는 산업으로 관광사업체조 
사의 모집단으로 설정할 수 있으며, 본 연구에서도 관광산업특수분류를 적용한 관 광산업조사의 단계별 적용방안을 위해 1차적으로 적용 가능한 핵심관광산업을 위 주로 살펴볼 것이다.

〈표 2-9〉 관광산업특수분류 포괄범위

\begin{tabular}{c|l}
\hline \multicolumn{1}{c|}{ 구분 } & \multicolumn{1}{c}{ 정의 } \\
\hline 핵심관광산업 & $\begin{array}{l}\text { 전적으로 관광객에 의존하는 산업으로 관광 쇼핑업, 관광 운수업, 관광 숙박업, 관 } \\
\text { 광 음식점 및 주점업, 여행사 및 여행보조 서비스업, 국제회의업, 문화·오락 및 레 } \\
\text { 저 스포츠산업, 카지노업을 포함하며, 주로 관광진흥법에서 규정한 관광산업을 포 } \\
\text { 함함 }\end{array}$ \\
\hline 상호의존 관광산업 & $\begin{array}{l}\text { 원래 관광산업은 아니지만 핵심 관광산업을 보조하기 위해 동반되는 산업으로 관 } \\
\text { 광 건설업, 관광 및 레저용품 소매업, 관광 금융 및 보험업, 레저장비업을 포함함 }\end{array}$ \\
\hline \multirow{2}{*}{ 부분적용 관광산업 } & $\begin{array}{l}\text { 부분적으로 관광객에 의존하는 산업으로 관광 비인증 쇼핑업, 부분관광 운송업, 부 } \\
\text { 분관광 숙박업, 부분관광 음식점 및 주점업, 부분관광 공연장업, 부분관광 기타 서 } \\
\text { 비스업을 포함함 }\end{array}$ \\
\hline 관광 지원산업 & $\begin{array}{l}\text { 관광산업을 지원하기 위한 부문으로 관광관련 관광 연구 개발업, 관광 공공기관, } \\
\text { 관광 교육서비스업, 관광단체를 포함함 }\end{array}$ \\
\hline
\end{tabular}

자료: 통계청, 통계분류포털(https://kssc.kostat.go.kr)

관광산업특수분류는 2000년에 제정된 이후 2008년, 2012년 2차례 개정이 진행 되었다. 2008년 1차 개정은 한국표준산업분류 9차 개정 내용 반영을 위한 연계표 개정 중심으로 이루어졌으며, 이와 함께 운수업에 여객자동차 터미널, 공항 운영업 등이 포함되는 기타 운송관련 서비스업이 신설되었다.

2012년 2차 개정은 1 차 개정과는 달리 분류체계 전반에 걸쳐 개정이 이루어졌는 데, 핵심, 상호의존, 부분, 지원산업의 4 개 영역 대분류로 변경함과 동시에 관광산 업특수분류와 관광진흥법상 관광사업분류 코드가 연계되도록 하였다.

세부적으로는 핵심관광산업에 면세점 신설, 관광 숙박업, 여행사업이 세분화되었 으며, 정보서비스업, 금융 및 보험업, 부동산 및 기계장비 임대업, 전문/과학 및 기 술서비스업, 공공행정/국방 및 사회보장행정 등은 상호의존, 부분, 지원산업으로 이 동하였다. 
〈표 2-10〉 관광산업특수분류 변화

\begin{tabular}{|c|c|}
\hline 개정 연도 & 내용 \\
\hline $\begin{array}{l}\text { 2008년 } \\
\text { (1차 개정) }\end{array}$ & $\begin{array}{l}\text { 한국표준산업분류 } 9 \overline{ } \text { 개정 내용 반영 } \\
\text { 운수업에 기타 운송관련 서비스업(여객자동차 터미널, 공항 운영업 등) 신설 }\end{array}$ \\
\hline $\begin{array}{l}\text { 2012년 } \\
\text { (2차 개정) }\end{array}$ & $\begin{array}{l}\text { 4개 영역의 대분류 분류체계로 변경 } \\
\text { 관광진흥법상 관광사업분류와 연계 개편 } \\
\text { 핵심관광산업에 면세점 신설, 관광 숙박업, 여행사업 세분화 } \\
\text { 정보서비스업, 금융 및 보험업, 부동산 및 기계장비 임대업, 전문/과학 및 기술서비스 } \\
\text { 업, 공공행정/국방 및 사회보장행정, 교육서비스업 등은 상호의존 관광산업, 부분 관광 } \\
\text { 산업, 관광 지원산업으로 이동 }\end{array}$ \\
\hline
\end{tabular}

자료: 통계청, 통계분류포털(https://kssc.kostat.go.kr)

2017년 12월 31일 기준 관광산업특수분류 기준 핵심관광사업체 수는 77,705 개 이며, 여기에는 분류되지 않는 사업체도 포함되어 있다. 분류되지 않는 사업체는 전 국 사업체조사에 포함된 정보가 부족하여 해당 한국표준산업분류 상에서 관광산업 을 영위하는지를 판단할 수 없는 사업체를 의미한다. 예를 들어, 한국표준산업분류 의 '한식 음식점업(5611)', '외국식 음식점업(5612)'에서 관광산업특수분류의 '관광 식당업(1040100)'을 정확하게 구별할 수 없는 경우 등이 해당된다.

관광산업특수분류의 핵심관광산업은 관광 쇼핑업 , 관광 운수업, 관광 숙박업, 관 광 음식점 및 주점업, 여행사 및 여행 보조 서비스업, 국제회의업, 문화, 오락 및 레저 스포츠산업, 카지노업의 8 개의 분류로 구분되며, 관광진흥법상의 관광사업을 별도로 표시하고 있다.

일반적으로 핵심관광산업의 경우 $100 \%$ 관광과 관련된 산업으로 정의할 수 있으 나 모텔 등의 일반 숙박시설과 일반음식점과 같은 식당 등이 상당수 포함되어 있기 때문에 조사 활용에 있어서 보다 체계적인 접근이 필요하다. 앞서 제시한 바와 같이 핵심관광산업을 관광산업통계 생산을 위한 조사 모집단으로 설정할 경우, 세부 분 류에서 관광 목적 비중을 파악할 수 없어 현재 조사 중인 관광진흥법상의 관광사업 체조사와는 반대로 과대 추정의 문제가 발생할 수 있다. 예를 들어, 한국표준산업분 류의 식당업, 주점업에서 관광식당업, 관광주점업을 구별하기는 쉽지 않기 때문에 해당 산업을 모두 관광으로 포함하여 조사할 경우 발생될 수 있는 문제이다. 
〈표 2-11〉 관광산업특수분류 핵심관광산업 규모

(단위: 개)

\begin{tabular}{|c|c|c|c|}
\hline \multicolumn{3}{|c|}{ 구분 } & 2017년 \\
\hline \multicolumn{3}{|c|}{ 핵심관광사업체 } & 77,705 \\
\hline \multirow{3}{*}{$\begin{array}{l}\text { 관광 쇼핑업 } \\
\text { (도매업 제외) }\end{array}$} & \multicolumn{2}{|l|}{ 면세점 } & 43 \\
\hline & \multicolumn{2}{|c|}{ 외국인전용 관광기념품 판매업a } & 1,152 \\
\hline & \multicolumn{2}{|c|}{ 관광 인증 쇼핑업 } & 288 \\
\hline \multirow{8}{*}{$\begin{array}{l}\text { 관광 } \\
\text { 운수업 }\end{array}$} & \multicolumn{2}{|l|}{ 관광 철도운송업 } & 109 \\
\hline & \multirow{3}{*}{$\begin{array}{c}\text { 관광 } \\
\text { 도로운송업 }\end{array}$} & 시내순환 관광업a & 2 \\
\hline & & 전세버스 운송업 & 1,182 \\
\hline & & 관광궤도업a & 19 \\
\hline & \multirow{2}{*}{$\begin{array}{c}\text { 관광 } \\
\text { 수상운송업 }\end{array}$} & 관광 유람선업 & 100 \\
\hline & & 크루즈업 & 18 \\
\hline & \multirow{2}{*}{ 관광 항공운송업 } & 관광 항공 정기운송업 & 132 \\
\hline & & 관광 항공 부정기운송업 & 1 \\
\hline \multirow{16}{*}{$\begin{array}{l}\text { 관광 } \\
\text { 숙박업 }\end{array}$} & \multirow{5}{*}{ 호텔업 } & 관광 호텔업a & \multirow{3}{*}{817} \\
\hline & & 수상관광 호텔업a & \\
\hline & & 한국전통 호텔업a & \\
\hline & & 가족 호텔업a & 10 \\
\hline & & 호스텔업a & 159 \\
\hline & \multicolumn{2}{|c|}{ 휴양콘도미니엄업a } & 311 \\
\hline & \multicolumn{2}{|l|}{ 관광 펜션업a } & 10,035 \\
\hline & \multirow{9}{*}{$\begin{array}{c}\text { 일반 관광 } \\
\text { 숙박업 }\end{array}$} & 산림휴양림업 & 31 \\
\hline & & 게스트하우스 & 909 \\
\hline & & 레지던스 호텔 & 32 \\
\hline & & 관광 인증 모텔업 & 6,078 \\
\hline & & 민박업 & 9,977 \\
\hline & & 외국인 관광 도시민박업a & 23 \\
\hline & & 자동차 야영장업a & 860 \\
\hline & & 한옥체험업a & 152 \\
\hline & & 기타 관광 숙박시설 운영업 & 2,215 \\
\hline \multirow{5}{*}{$\begin{array}{l}\text { 관광 음식점 } \\
\text { 및 주점업 }\end{array}$} & \multicolumn{2}{|l|}{ 관광 식당업a } & 14,707 \\
\hline & \multirow{4}{*}{$\begin{array}{l}\text { 관광 } \\
\text { 주점업 }\end{array}$} & 관광 유흥음식점업a & 9,536 \\
\hline & & 관광 극장유흥업a & 103 \\
\hline & & 관광 공연장업a(주점업)* & - \\
\hline & & 외국인전용 유흥음식점업a & 329 \\
\hline
\end{tabular}




\begin{tabular}{|c|c|c|c|}
\hline \multicolumn{3}{|c|}{ 구분 } & 2017년 \\
\hline \multirow{4}{*}{$\begin{array}{c}\text { 여행사 및 여행 보조 } \\
\text { 서비스업 }\end{array}$} & \multirow{3}{*}{ 여행업 } & 일반 여행업a & 7,578 \\
\hline & & 국외 여행업a & 837 \\
\hline & & 국내 여행업a & 713 \\
\hline & \multicolumn{2}{|c|}{ 여행보조 및 예약 서비스업 } & 971 \\
\hline \multirow{2}{*}{ 국제회의업 } & \multicolumn{2}{|l|}{ 국제회의 기획업 } & 337 \\
\hline & \multicolumn{2}{|l|}{ 국제회의 시설업a } & 2 \\
\hline \multirow{16}{*}{$\begin{array}{l}\text { 문화, 오락 및 } \\
\text { 레저 스포츠산업 }\end{array}$} & \multirow{2}{*}{$\begin{array}{l}\text { 박물관 및 } \\
\text { 사적지 } \\
\text { 관리 운영업 }\end{array}$} & 박물관 운영업(미술관 포함) & 1,379 \\
\hline & & 사적지 관리 운영업 & 216 \\
\hline & \multirow{3}{*}{$\begin{array}{c}\text { 식물원, } \\
\text { 동물원 및 } \\
\text { 자연공원 } \\
\text { 운영업 }\end{array}$} & 식물원, 동물원 운영업 & 169 \\
\hline & & 자연공원 운영업 & 391 \\
\hline & & 기타 관광지 운영업 & 17 \\
\hline & \multirow{3}{*}{ 유원시설업 } & 종합유원시설업a & 32 \\
\hline & & 일반유원시설업 & 206 \\
\hline & & 기타유원시설업a & 1,335 \\
\hline & \multicolumn{2}{|c|}{ 농어촌 체험 및 생태 관광업 } & 46 \\
\hline & \multicolumn{2}{|c|}{ 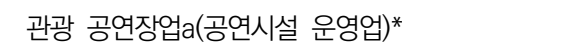 } & 110 \\
\hline & \multirow{5}{*}{$\begin{array}{c}\text { 관광 레저 } \\
\text { 스포츠시설 운영업 }\end{array}$} & 경주장 운영업 & 15 \\
\hline & & 골프장 운영업 & 433 \\
\hline & & 스키장 운영업 & 2 \\
\hline & & 낚시장 운영업 & 892 \\
\hline & & 수상 오락 서비스업 & 598 \\
\hline & $\begin{array}{c}\text { 기타 분류 } \\
\text { 안 된 오락 } \\
\text { 관련 서비스업 }\end{array}$ & 오락 및 관광체험시설 운영 & 2,080 \\
\hline \multirow{2}{*}{ 카지노업 } & \multicolumn{2}{|c|}{ 외국인 전용 카지노업a } & 15 \\
\hline & \multicolumn{2}{|c|}{ 내국인 출입 카지노업a } & 1 \\
\hline
\end{tabular}

주: 'a'는 관광진흥법상의 관광사업을 표기함 


\section{2. 유사 산업분류}

문화체육관광 관련 산업특수분류에는 앞서 살펴본 관광산업특수분류 이외에 저 작권산업특수분류, 콘텐츠산업특수분류, 스포츠산업특수분류가 있으며, 3 개의 산업 특수분류는 각각 해당 산업 통계조사의 기준으로 활용되고 있다. 여기서는 관광산 업특수분류와 유사한 산업특수분류의 분류체계를 살펴보고자 한다.

\section{가. 저작권산업특수분류}

저작권산업특수분류는 세계지적재산권기구(World Intellectual Property Organization; WIPO)의「저작권기반산업의 경제적 기여도 조사 가이드」를 근거 로 저작권산업의 정책수립에 필요한 분류체계를 수립하기 위하여 2011년에 제정되 었다. 여기서 저작권산업은 $\mathrm{WIPO}$ 의 정의와 동일하게 창작물 및 보호대상물(소설, 시, 음악, 미술, 지도, 설계도안, 영화, 소프트웨어 등)의 창작, 생산, 공연, 방송, 전 시 또는 도소매 활동을 영위하는 산업과 저작권이 그 산업의 수립에 중요한 역할을 하는 산업으로 정의한다.

저작권산업특수분류는 $\mathrm{WIPO}$ 의 저작권산업 포괄범위를 바탕으로 저작권산업을 창작활동에 의존하는 정도에 따라 핵심 저작권산업, 상호의존 저작권산업, 부분 저 작권산업, 저작권 지원산업으로 분류하고 있어 관광산업특수분류와 유사한 분류체 계를 보이고 있다. 특히, 부분 저작권산업의 경우에는 비주기적으로 저작권 요소비 중 조사를 진행하여 그 결과를 매년 발간되는 한국의 저작권산업 경제 기여도 조사 에 활용하고 있다. 
〈표 2-12〉 저작권산업특수분류 포괄범위

\begin{tabular}{|c|c|}
\hline 구분 & 정의 \\
\hline 핵심 저작권산업 & 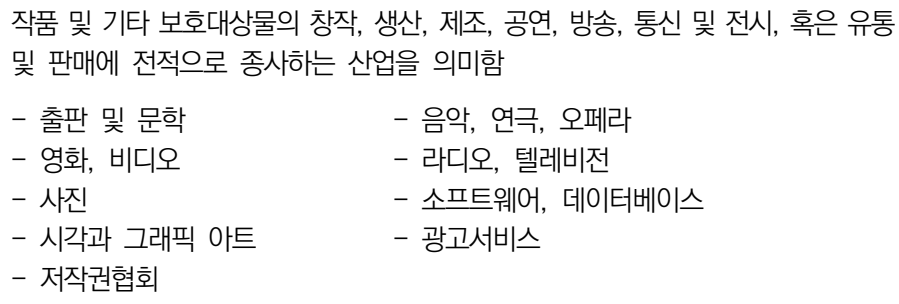 \\
\hline 상호의존 저작권산업 & $\begin{array}{l}\text { 그 기능이 전적으로 혹은 주로 저작물의 창조 생산 및 사용을 가능하게 하는 기기 } \\
\text { 의 생산, 제조, 판매에 종사하는 산업을 의미함 }\end{array}$ \\
\hline 부분적용 저작권산업 & $\begin{array}{l}\text { 부분적으로 저작물의 창조, 생산, 제조, 수행, 방송, 통신과 전시 및 유통 판매에 } \\
\text { 관여하는 산업을 의미함 }\end{array}$ \\
\hline 저작권 지원산업 & $\begin{array}{l}\text { 내부의 부분적인 활동이 저작권 및 관련물의 방송, 통신, 판매 및 유통에 기여하며 } \\
\text { 그 활동이 핵심저작권 산업에 해당하지 않는 산업을 의미함 }\end{array}$ \\
\hline
\end{tabular}

자료: 통계청, 통계분류포털(https://kssc.kostat.go.kr)

\section{나. 콘텐츠산업특수분류}

콘텐츠산업특수분류는 콘텐츠미디어산업분류, 2009 UNESCO Framework for Cultural Statistics 등을 토대로 2010년 제정되었다. 콘텐츠산업특수분류에서의 콘텐츠산업 포괄범위는 음악, 영화·비디오, 애니메이션 산업, 방송 산업, 게임 산업, 공연 산업, 공예품 및 디자인업, 광고 산업, 정보서비스업, 지적재산권 관리업 등으 로 정하고 있다.

콘텐츠산업특수분류에서는 콘텐츠산업을 크게 12 개 산업으로 구분하고 있으며, 이를 기준으로 국가승인통계 콘텐츠산업통계조사가 생산되고 있다. 
〈표 2-13〉 콘텐츠산업특수분류 포괄범위

\begin{tabular}{|c|c|c|}
\hline 구분 & & 중분류 \\
\hline 출판산업 & $\begin{array}{l}\text { - 출판업 } \\
\text { - 출판 도소매업 } \\
\text { - 출판 임대업 }\end{array}$ & $\begin{array}{l}\text { - 인쇄업 } \\
\text { - 온라인 출판 유통업 }\end{array}$ \\
\hline 만화산업 & $\begin{array}{l}\text { - 만화 출판업 } \\
\text { - 만화책 임대업 }\end{array}$ & $\begin{array}{l}\text { - 온라인 만화 제작·유통업 } \\
\text { - 만화 도소매업 }\end{array}$ \\
\hline 음악산업 & $\begin{array}{l}\text { - 음악제작업 } \\
\text { - 음반복제 및 배급업 } \\
\text { - 온라인 음악 유통업 } \\
\text { - 노래연습장 운영업 }\end{array}$ & $\begin{array}{l}\text { - 음악 및 오디오물 출판업 } \\
\text { - 음반 도소매업 } \\
\text { - 음악 공연업 }\end{array}$ \\
\hline 영화산업 & - 영화 제작, 지원, 및 유통업 & - DVD/VHS 제작 및 유통업 \\
\hline 게임산업 & $\begin{array}{l}\text { - 게임 제작 및 배급업 } \\
\text { - 게임 도소매 및 임대업 }\end{array}$ & - 게임 유통업 \\
\hline 애니메이션산업 & $\begin{array}{l}\text { - 애니메이션 제작업 } \\
\text { - 온라인 애니메이션 유통업 }\end{array}$ & - 애니메이션 유통 및 배급업 \\
\hline 방송산업 & $\begin{array}{l}\text { - 지상파 방송 } \\
\text { - 위성방송 } \\
\text { - 전광판방송 } \\
\text { - 방송영상물 배급 및 중개업 }\end{array}$ & $\begin{array}{l}\text { - 유선방송 } \\
\text { - 방송채널사용사업 } \\
\text { - 인터넷 영상물 제공업 } \\
\text { - 방송관련 단체 }\end{array}$ \\
\hline 광고산업 & $\begin{array}{l}\text { - 광고(종합)대행업 } \\
\text { - 서비스업 } \\
\text { - 온라인업 }\end{array}$ & $\begin{array}{l}\text { - 광고 제작업 } \\
\text { - 인쇄업 } \\
\text { - 기타업 }\end{array}$ \\
\hline 캐릭터산업 & $\begin{array}{l}\text { - 캐릭터 제작업 } \\
\text { - 캐릭터 놀이시설 운영업 }\end{array}$ & $\begin{array}{l}\text { - 캐릭터 상품 유통업 } \\
\text { - 캐릭터 상품 온라인 유통업 }\end{array}$ \\
\hline 지식정보산업 & $\begin{array}{l}\text { - e-learning업 } \\
\text { - 가상세계 및 가상현실업 }\end{array}$ & $\begin{array}{l}\text { - 기타 데이터베이스 및 온라인정보 제공업 } \\
\text { - 포털 및 기타 인터넷 정보 매개 서비스법 }\end{array}$ \\
\hline 콘텐츠솔루션산업 & - 콘텐츠솔루션업 & - 컴퓨터그래픽스(CG) 제작업 \\
\hline 공연산업 & - 공연업 & - 공연관련 서비스업 \\
\hline
\end{tabular}

자료: 통계청, 통계분류포털(https://kssc.kostat.go.kr)

\section{다. 스포츠산업특수분류}

스포츠산업특수분류는 '국민체육진흥법'과 '체육시설의 설치·이용에 관한 법률' 등에서 제시한 스포츠산업 정의와 중앙생산물분류(CPC2.0)의 스포츠관련 산업 및 생산물의 정의를 바탕으로 2000년에 제정되었다. 스포츠산업특수분류에서의 스포 츠산업 포괄범위는 '국민체육진흥법’에 따른 체육활동을 지원하는 제조업, 건설업, 
관련 서비스업과 스포츠서비스를 제공하기 위해서 재화와 서비스를 생산·유통하는 산업으로 정의하고 있다.

스포츠산업특수분류에서는 스포츠산업은 크게 스포츠 시설업, 스포츠 용품업, 스 포츠 서비스업의 3개 산업으로 구분하고 있으며, 이를 기준으로 국가승인통계 스포 츠산업실태조사 생산되고 있다.

〈표 2-14〉스포츠산업특수분류 포괄범위

\begin{tabular}{c|ll}
\hline 구분 & \multicolumn{2}{|c}{ 중분류 } \\
\hline 스포츠 시설업 & - 스포츠시설 운영업 & - 스포츠시설 건설업 \\
\hline 스포츠 용품업 & - 운동 및 경기용품업 & - 운동 및 경기용품 유통 및 임대업 \\
\hline 스포츠서비스업 & $\begin{array}{l}\text { - 스포츠 경기 서비스업 } \\
- \text { 스포츠 교육기관 }\end{array}$ & $\begin{array}{l}- \text { 스포츠 정보 서비스업 } \\
- \text { 기타 스포츠 서비스업 }\end{array}$ \\
\hline
\end{tabular}

자료: 통계청, 통계분류포털(https://kssc.kostat.go.kr)

\section{3. 관광진흥법상 관광산업분류와 관광산업특수분류 핵심관광산업 비교}

관광진흥법상 관광산업분류는 여행업, 숙박업 등 전통적인 관광 업종 위주로 규 정하고 있어, 확장된 관광산업 전반을 포괄하지 못하고 있다. 그리고 등록·허가·신 고·지정된 사업체만을 대상으로 하고 있어 관광산업에 대한 과소추정 문제를 가지 고 있다. 수요와 공급 측면에서 내·외국인의 소비지출과 관광사업체의 매출액의 차 이를 비교해 보면 다음과 같다.

수요 차원에서 국민여행실태조사의 국내 여행 지출액 약 43 조 1,330 억 원, 국제 수지의 일반여행수입 약 20조 3,255억 원(2018년 평균 환율 1,101 원 적용)으로 나타난 반면 공급 측면에서의 2018년 기준 관광사업체의 전체 매출액은 약 25 조 4,290 억 원으로 수요와 공급의 매출액 불균형이 매우 큰 것으로 나타났다. 이에 관 광진흥법 규정에 근거하여 관광산업으로 분류된 총 7 개 업종에 등록·허가·신고·지 정된 사업체를 조사 모집단으로 하는 관광사업체조사(국가승인통계)의 통계품질진 단 결과에서도 관광산업에 대해 관광산업특수분류를 활용할 수 있는 기반마련과 활 용을 권고하고 있다. 
관광산업특수분류는 관광산업 관련 조사 및 연구 등에 일관성 있는 분류 기준을 적용하기 위한 목적으로 제정되었으나 실제 활용성은 낮다. 그 이유는 한국표준산 업분류에서 관광산업특수분류에 해당하는 사업체, 즉 개별 사업체의 관광 목적 비 율을 정확하게 알 수 없기 때문에 이를 모두 포함할 경우 과대 추정의 문제가 발생 할 수 있기 때문이다. 그나마 관광산업특수분류의 활용성을 높이기 위해 핵심관광 산업에 관광진흥법상의 관광산업을 별도로 표시하고 있으나, 이마저도 관광진흥법 상 사업체와 $100 \%$ 일치하지 않기 때문에 활용상의 어려움이 발생된다.

2018년 기준 사업체 수를 비교해 보면, 관광진흥법상 관광사업체는 33,452개이 며 관광산업특수분류 핵심관광산업에 해당하는 사업체는 77,705 개(분류되지 않는 사업체 포함)로 규모면에서 거의 2 배 이상의 차이를 보이고 있다. 또한 포함되는 산업분류에서도 정확히 매칭이 어려운 점과 더불어 핵심관광산업 전체를 $100 \%$ 관 광산업으로 활용할 수 있는지에 대한 검토도 필요하다. 보다 세부적인 산업 비교는 제3장에서 살펴보도록 한다.

〈표 2-15〉 관광진흥법상 관광사업분류와 관광산업특수분류 핵심관광산업 비교

\begin{tabular}{c|l|l}
\hline 구분 & \multicolumn{1}{|c|}{ 관광진흥법 } & \multicolumn{1}{|c}{ 관광산업특수분류 핵심관광산업 } \\
\hline 산업 정의 & $\begin{array}{l}\text { 관광객을 위하여 운송·숙박·음식·운동· } \\
\text { 오락·휴양 또는 용역을 제공하거나 그 밖 } \\
\text { 에 관광에 딸린 시설을 갖추어 이를 이용 } \\
\text { 하게 하는 업 }\end{array}$ & 전적으로 관광객에 의존하는 산업 \\
\hline 산업 대상 & $\begin{array}{l}\text { 관광진흥법상 등록·허가·신고·지정된 } \\
\text { 사업체 }\end{array}$ & $\begin{array}{l}\text { 전국 사업체조사 대상 사업체 중에서 } \\
\text { 관광산업특수분류 해당 사업체 }\end{array}$ \\
\hline $\begin{array}{c}\text { 산업 규모 } \\
\text { (2017년 기준) }\end{array}$ & 33,452개 사업체 & $\begin{array}{l}\text { 77,705개 사업체 } \\
\text { (분류되지 않는 사업체 35,067개 포함) }\end{array}$ \\
\hline 활용 가능 최신 자료 & 2018년 기준 자료 & 2017년 기준 자료 \\
\hline
\end{tabular}

자료: 문화체육관광부(2019). 『2018 관광사업체조사』. 


\section{제3절 시사점}

\section{1. 관광산업분류}

본 장에서는 관광진흥법상 관광산업분류와 더불어 관광산업특수분류를 포함한 국내·외의 관광산업분류와 유사산업 분류의 체계를 살펴보았다. 현황 분석을 통해 다음 3가지의 관광산업특수분류를 활용한 관광산업통계 조사 확대 방안을 도출할 수 있다.

첫째, 기존의 관광산업특수분류의 4 개 대분류(핵심, 상호의존, 부분적용, 지원산 업)를 유지한다. 관광산업과 관련해서는 UN의 관광위성계정 관광상품분류에서는 3 개의 분류체계, $\mathrm{UNWTO}$ 의 관광활동의 국제표준분류에서는 2 개의 분류체계를 관 광산업분류로 설정하였으며 유사 산업분류에서는 세계지적재산권기구의 저작권산 업분류에서는 현재 관광산업특수분류와 동일한 4 개의 분류체계, 중국의 문화산업분 류에서는 3개의 분류체계를 적용하여 해당 산업을 크게 핵심산업을 중심으로 2 4 개의 대분류로 구분하고 있다. 관광산업은 숙박, 교통, 음식, 문화 등과 연계되어 파급효과가 큰 산업으로 관광산업에 대한 기여도와 역할에 따른 4 개 대분류를 유지 하되, 본 연구에서는 분류체계를 기반으로 관광산업통계 생산의 단계별 모집단을 종합적으로 검토하고자 한다.

〈표 2-16〉 국내외 관광, 유사산업 분류별 포괄범위 비교

\begin{tabular}{c|c|c}
\hline \multicolumn{2}{c|}{ 분류 } & 포괄범위 \\
\hline \multirow{4}{*}{ 해외 } & UN의 관광위성계정 관광상품분류 & 핵심, 연계, 비관광 관련 소비 상품 \\
\cline { 2 - 3 } & UNWTO의 관광활동의 국제표준분류 & 핵심, 부분산업 \\
\cline { 2 - 3 } & 세계지적재산권기구의 저작권산업분류 & 핵심, 상호의존, 부분적용, 지원산업 \\
\cline { 2 - 3 } & 중국의 문화산업분류 & 핵심층, 외각층, 관련층 \\
\cline { 2 - 3 } & UNWTO의 MICE산업분류 & 핵심, 확장사업 \\
\hline
\end{tabular}




\begin{tabular}{c|c|c}
\hline \multicolumn{2}{c|}{ 분류 } & 포괄범위 \\
\hline \multirow{4}{*}{ 국내 } & 관광진흥법상 관광사업분류 & 업종 기준 \\
\cline { 2 - 3 } & 관광산업특수분류 & 핵심, 상호의존, 부분적용, 지원산업 \\
\cline { 2 - 3 } & 저작권산업특수분류 & 핵심, 상호의존, 부분적용, 지원산업 \\
\cline { 2 - 3 } & 콘텐츠산업특수분류 & 업종 기준 \\
\cline { 2 - 3 } & 스포츠산업특수분류 & 업종 기준 \\
\cline { 2 - 3 } &
\end{tabular}

둘째, 관광산업특수분류는 관광진흥법상 관광산업분류와 연계될 수 있도록 구축 한다. 관광관련 정책을 수립하기 위한 기초 자료에 해당하는 관광사업체조사의 조 사모집단은 관광진흥법상 등록-허가·신고·지정되어 있는 관광사업체에 한정되어 있어 관광산업을 대표하지 못하는 한계점이 발생한다. 또한 관광산업특수분류를 기 준으로 조사를 진행하면 정확한 산업의 규모를 추정하기 위해 관광 목적 비중 (Tourism Ratio)을 파악해야 한다. 본 연구에서는 관광산업의 포괄범위를 고려하 여 관광산업특수분류를 개정하며, 활용성 제고 측면에서 관광진흥법상 관광산업분 류와 연계될 수 있도록 한다. 즉, 미시적(관광진흥법)·거시적(관광진흥법 $+\alpha$ ) 차원의 관광산업을 분류할 수 있는 기준을 마련해야 한다.

셋째, 개정된 관광산업특수분류를 기준으로 실제 관광산업통계 조사까지 이어질 수 있는 세부적인 조사방안을 제시한다. 문화체육관광 관련 산업특수분류에는 관광 산업특수분류, 저작권산업특수분류, 콘텐츠산업특수분류, 스포츠산업특수분류가 있 으며, 관광산업특수분류를 제외한 3 개의 산업특수분류는 각각 해당 특수분류를 조 사의 기준으로 활용되고 있다. 관광산업특수분류는 2000 년에 제정되어 2 차 개정까 지 공표되었으나, 실제 조사에는 활용되지 않고 있다. 관광산업특수분류를 관광산 업통계 조사에 적용하여 통계를 산출하기 위해서 모집단 확보 가능성, 표본설계, 모 수 추정, 기존 통계와의 시계열 유지 가능성 및 비교 방법 등 전체적인 조사설계를 검토해야 한다. 특히 기존의 설계 및 분류체계와 분류 개정과 조사 확대방안을 통해 도출한 설계 및 분류체계를 모두 적용하여 조사 결과를 도출할 수 있도록 한다. 또 한 관광산업특수분류 적용시 가장 문제가 되는 관광목적비율(Tourism Ratio) 도출 을 위한 시범조사를 통해 관광산업특수분류 적용을 통한 관광산업통계의 신뢰성 있 는 생산방안을 검토한다. 

관광산업특수분류 개정안에 기초한 관광산업통계 생산방안 연구

제3장

관광산업특수분류

개정방안 



\section{제1절 관광산업특수분류 개정 방향}

\section{1. 산업적 관점에서의 개정 방향}

본 연구에서는 기존 관광산업특수분류를 기준으로 관광산업의 환경 변화, 관광진 흥법 개정 내용, 한국표준산업분류 10 차 개정 내용, 조사방안 등을 모두 고려하여 관광산업특수분류 3 차 개정안 도출한다.

관광산업특수분류는 관광진흥법상의 관광산업을 구별할 수 있도록 각 산업분류 에 별도의 ' $\mathrm{a}$ ' 코드를 부여하여 기존에 관광진흥법으로 조사된 관광산업과 관광산 업특수분류체계를 적용한 관광산업을 이원화하여 활용할 수 있도록 구성되어 있다. 즉, 관광산업특수분류의 핵심관광산업은 관광진흥법상 관광산업을 모두 포함하여 구축되어 있다.

[그림 3-1] 관광진흥법상의 관광사업과 관광산업특수분류의 관광산업 포괄범위

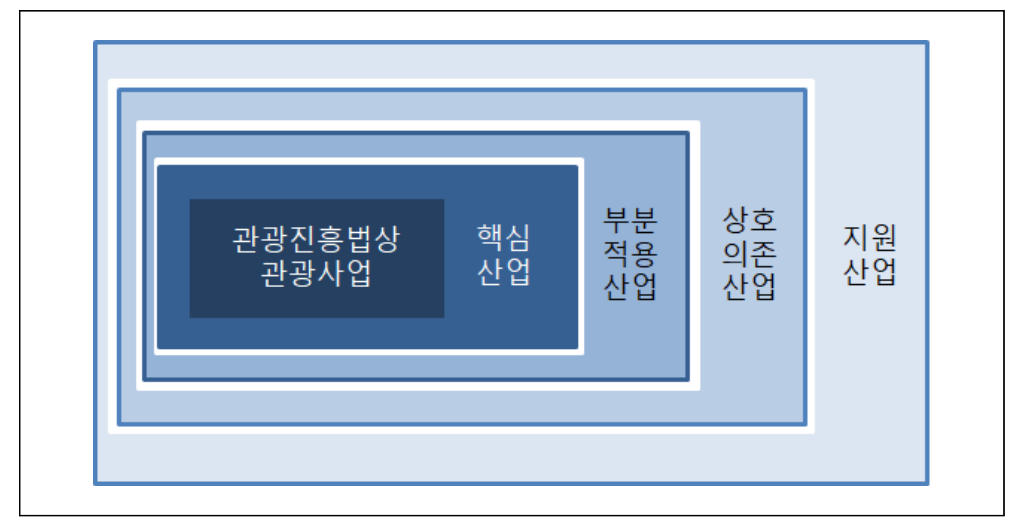


본 연구에서는 관광산업특수분류 개정안을 마련하고 향후 관광산업통계의 1 차 모집단이 될 수 있는 핵심관광산업 개정을 통해 실제 관광산업통계 조사에 활용될 수 있도록 모집단을 설정한다. 세부내용으로는 10 차 한국표준산업분류의 개정 검토 를 통한 연계표 재설정을 비롯하여 관광진흥법 개정에 따른 업종의 신설·삭제·이동 을 확인하고 전문가 자문회의 및 핵심관광산업 타당성 조사를 통해 관광산업특수분 류 핵심관광산업 업종을 최종 도출한다.

\section{2. 분류체계 관점에서의 개정 방향}

\section{가. 한국표준산업분류와 연계}

관광산업특수분류는 한국표준산업분류의 세세분류(5자리 숫자)와 연계가 가능하 도록 한국표준산업분류의 산업 특성 및 세부 품목 분석을 통해 연계표를 작성한다. 한국표준산업분류는 우리나라 전체 산업 범위를 설정하고 산업관련 통계자료의 정 확성, 비교성을 확보하기 위하여 작성된 통계분류로 관광산업특수분류를 포함한 특 정 산업에 해당하는 분류(산업특수분류 등)는 활용도 측면을 고려하여 한국표준산 업분류와의 연계가 필요하다.

한국표준산업분류와의 연계표 작성시에는 한국표준산업분류와 관광산업특수분 류가 일대일로 연계되는 경우와 그렇지 않는 경우로 나누어 일대일 연계가 되지 않 는 경우에는 별도로 한국표준산업분류 코드에 '*’를 표시한다. ‘*' 표시는 관광산업 특수분류의 해당 산업이 한국표준산업분류와 일치하지 않는 것으로, 한국표준산업 분류의 해당 산업에서 관광산업에 해당하는 세부 품목을 선별하거나 하나의 한국표 준산업분류 산업이 2개 이상으로 분할되는 경우를 의미한다.

한국표준산업분류와 연계함으로써 국제표준산업분류, 산업연관표와도 연계가 가 능하며, 관광산업특수분류를 활용한 관광산업통계 조사를 위한 표본틀 갱신시에 활 용함으로써 시의성 있는 표본틀 구축이 가능해진다. 


\section{나. 한국표준산업분류체계 준용}

관광산업특수분류의 분류구조와 부호체계는 한국표준산업분류체계 기준을 준용 한다. 한국표준산업분류의 산업분류 적용원칙을 살펴보면, 생산단위는 산출물뿐만 아니라 투입물과 생산 공정 등을 함께 고려하여 그들의 활동을 가장 정확하게 설명 된 항목으로 분류하고 있다. 그리고 복합적인 활동단위는 우선적으로 최상급 분류 단계(대분류)를 정확히 결정하고 순차적으로 중소·세분류 단계 항목을 결정하며, 산 업 활동이 결합되어 있는 경우에는 그 활동단위의 주된 활동에 따라서 분류한다(통 계청, 2017).

관광산업특수분류 구조는 대분류(1자리 숫자 사용), 중분류(2자리 숫자 사용), 소 분류(2자리 숫자 사용), 세분류(2자리 숫자 사용)의 4단계로 구성하여 총 7자리의 코드를 부여한다. 중분류 이하의 분류는 01부터 99까지를 부여하며, 향후 분류가 추가될 것을 고려하여 분류별 사이에 번호 여백을 둔다. 여기서 '99'는 기타 항목을 의미하며, 앞에서 산업이 명확하게 분류되어 남아 있는 활동이 없는 경우에는 ‘99' 기타 항목이 필요 없는 경우도 있다. 또한 각 분류 단계에서 더 이상 하위분류가 세분화되지 않는 경우에는 ‘00’을 사용한다. 예를 들어, 면세점은 소분류 코드가 ‘10101’이며, 소분류가 더 이상 세분화되지 않아 세분류 코드는 ‘ $1010100 ’$ 이다. 


\section{제2절 관광산업특수분류 개정 절차}

\section{1. 관광산업특수분류 개정 절차}

본 연구에서는 관광산업특수분류 개정(안)을 도출하기 위해 국내·외 사례분석 결 과를 바탕으로 전문가 자문회의(1차)와 전문가 설문조사(2차) 진행을 통해 최종 개 정안을 도출하였다.

먼저 국내·외 사례분석을 통해 관광산업특수분류 1 차 개정(안) 도출한다. 이때는 현재의 관광산업특수분류의 핵심관광산업을 토대로 관광진흥법상의 관광사업분류 와 관광위성계정 권고안(TSA:RMF 2008)의 관광상품분류 등을 함께 비교·분석한 다. 둘째, 1 차 개정(안)을 기준으로 전문가 자문회의를 실시하고 1 차 개정(안)을 수 정-보완한 2차 개정(안)을 도출한다. 셋째, 관광산업분류, 관광산업 파급 효과 분석 등의 전문가들을 대상으로 패널을 구성하여 2차에 걸친 전문가 의견조사를 진행한 다. 전문가 의견조사에서는 처음부터 구조화된 설문지를 활용함으로써 절차를 3 차 에서 2차로 횟수를 줄여 조사의 편리성과 효율성 제고하고자 한다(이종성, 2001). 마지막으로 조사결과의 평균값과 응답의 타당도를 검증한 전문가 의견조사 결과를 바탕으로 최종 관광산업특수분류 개정(안)을 확정한다. 확정된 관광산업특수분류 개정안의 최종 검증을 위해 한국표준산업분류 및 산업특수분류 제·개정을 담당하고 있는 통계청 기준과 및 관광사업체조사를 담당하고 있는 문화체육관광부 관광산업 정책과의 의견을 수렴하는 과정을 거친다. 
〈표 3-1〉 관광산업특수분류 개정 절차

\begin{tabular}{|c|c|c|}
\hline & 구분 & 내용 \\
\hline \multicolumn{2}{|c|}{ 관광산업특수분류 개정(안) 도출 } & 국내외 사례분석을 통해 관광산업특수분류 1차 개정(안) 도출 \\
\hline \multicolumn{2}{|c|}{ 1차 전문가 자문회의 } & $\begin{array}{l}1 \text { 차 개정(안)을 기준으로 전문가 자문회의 실시 } \\
1 \text { 차 개저(아)으 스저.버와하 2 차 개저(아) 드츠 }\end{array}$ \\
\hline \multirow{4}{*}{$\begin{array}{l}\text { 전문가 } \\
\text { 의견조사 }\end{array}$} & 사전 준비 & 전문가 조사 전문가 패널 선정 \\
\hline & 1차 전문가 조사 & $\begin{array}{l}2 \text { 차 개정(안)을 기준으로 전문가 조사 진행 } \\
2 \text { 차 개정(안)을 수정·보완한 } 3 \text { 차 개정(안) 도출 }\end{array}$ \\
\hline & 2차 전문가 조사 & 3차 개정(안)을 기준으로 전문가 조사 진행 \\
\hline & 타당도 및 신뢰도 검증 & 도출된 분류에 대한 타당도 및 신뢰도 검증 \\
\hline \multicolumn{2}{|c|}{ 2차 전문가 자문회의 } & $\begin{array}{l}\text { 관광산업특수분류 개정(안) 최종 수정·보완 } \\
\text { 통계청과 문화체육관광부 의견 수렴 }\end{array}$ \\
\hline \multicolumn{2}{|c|}{ 관광산업특수분류 개정 } & 최종 관광산업특수분류 개정(안) 도출 및 개정 \\
\hline
\end{tabular}

\section{2. 전문가 자문회의}

1 차 전문가 자문회의의 목적은 관광산업특수분류 개정을 위한 의견을 수렴하고 이를 바탕으로 전문가 조사를 위한 내용 구성 및 핵심관광산업에서 관광비중 조사 가 필요한 산업을 검토하는 것이다. 1 차 전문가 자문회의는 관광진흥법상 관광산업 을 반영한 개정 내용과 한국표준산업분류 및 조사 적용 방안 등을 고려한 기타 개정 내용으로 나누어서 검토하였다.

\section{가. 관광진흥법상 관광산업을 반영한 검토 내용}

관광산업특수분류는 관광진흥법상의 관광산업을 각 산업 분류명에 'a'로 표시하 여 별도로 구분하고 있으나, 2012년에 마지막으로 개정되어 그 이후의 관광진흥법 의 개정 내용을 전혀 반영하고 있지 못하고 있다. 따라서 관광진흥법상의 신규 관광 사업 등 관광진흥법상의 관광산업과의 비교·분석을 먼저 진행하였다.

먼저, 관광진흥법상의 관광산업에 포함되어 있으나 관광산업특수분류에는 포함 되어 있지 않았던 소형호텔업, 의료관광호텔업, 일반야영장업, 전문휴양업, 종합휴 
양업을 추가하였으며, 이때에는 모집단 구축 및 조사 적용 가능 여부도 함께 고려하 였다. 전문휴양업과 종합휴양업은 관광진흥법상에서 사용하고 있는 산업으로 연계 되는 한국표준산업분류를 살펴보면, 숙박업(55), 창작, 예술 및 여가관련 서비스업 (90), 스포츠 및 오락관련 서비스업(91), 욕탕업(96121) 등 다양한 산업에 포함되어 있어 향후 조사시에는 관광진흥법상 등록·허가·신고·지정되어 있는 사업체 모집단 을 활용하는 모집단 이원화 방안도 검토해야 할 것으로 판단된다.

〈표 3-2〉 전문 및 종합휴양업 정의

\begin{tabular}{|c|c|c|}
\hline \multicolumn{2}{|r|}{ 구분 } & 정의 \\
\hline \multicolumn{2}{|r|}{ 전문휴양업 } & $\begin{array}{l}\text { 관광객의 휴양이나 여가 선용을 위하여 숙박업 시설이나 「식품위생법 시 } \\
\text { 행령, 제 } 21 \text { 조 제8호 가목·나목 또는 바목에 따른 휴게음식점영업, 일반 } \\
\text { 음식점영업 또는 제과점영업의 신고에 필요한 시설을 갖추고 전문휴양 } \\
\text { 시설 중 한 종류의 시설을 갖추어 관광객에게 이용하게 하는 업 }\end{array}$ \\
\hline \multirow{2}{*}{$\begin{array}{c}\text { 종합 } \\
\text { 휴양업 }\end{array}$} & 제1종 종합휴양업 & $\begin{array}{l}\text { 관광객의 휴양이나 여가 선용을 위하여 숙박시설 또는 음식점시설을 갖 } \\
\text { 추고 전문휴양시설 중 두 종류 이상의 시설을 갖추어 관광객에게 이용하 } \\
\text { 게 하는 업이나, 숙박시설 또는 음식점시설을 갖추고 전문휴양시설 중 } \\
\text { 한 종류 이상의 시설과 종합유원시설업의 시설을 갖추어 관광객에게 이 } \\
\text { 용하게 하는 업 }\end{array}$ \\
\hline & 제2종 종합휴양업 & $\begin{array}{l}\text { 관광객의 휴양이나 여가 선용을 위하여 관광숙박업의 등록에 필요한 시 } \\
\text { 설과 제1 } 1 \text { 종 종합휴양업의 등록에 필요한 전문휴양시설 중 두 종류 이상 } \\
\text { 의 시설 또는 전문휴양시설 중 한 종류 이상의 시설 및 종합유원시설업 } \\
\text { 의 시설을 함께 갖추어 관광객에게 이용하게 하는 업 }\end{array}$ \\
\hline
\end{tabular}

관광사진업은 기존에 부분관광산업에 포함되어 있었으나, 관광진흥법과의 연계 를 위해 핵심관광산업 중분류 여행사 및 여행보조 서비스업의 소분류 관광관련 전 문기술 서비스업으로 이동을 검토하였다.

관광공연장업은 '관광객을 위하여 적합한 공연시설을 갖추고 공연물을 공연하면 서 관광객에게 식사와 주류를 판매하는 업'으로 기존에는 중분류 관광 음식점 및 주 점업에 포함되어 있었으나, 산업의 주된 성격이 식사와 주류 판매가 아니라 공연이 라는 점을 고려하여 중분류 문화, 오락 및 레저 스포츠산업으로 이동을 검토하였다.

그리고 외국인전용 관광기념품 판매업의 경우에는 관광진흥법에서 2014년에 제 외되었으나, 관광기념품 판매업은 관광 쇼핑업에서 중요한 부분으로 분류명 및 포 괄범위를 변경을 검토하였다. 
〈표 3-3〉 관광진흥법상 관광산업을 반영한 검토 내용

\begin{tabular}{|c|c|c|c|}
\hline 중분류 & 소분류 & 세분류 & 검토 내용 \\
\hline 관광 쇼핑업 & $\begin{array}{c}\text { 외국인전용 관광기념품 } \\
\text { 판매업 }\end{array}$ & $\begin{array}{c}\text { 외국인전용 관광기념품 } \\
\text { 판매업 }\end{array}$ & $\begin{array}{c}\text { 관광기념품 판매업으로 분류명 } \\
\text { 및 포괄범위 변경 }\end{array}$ \\
\hline \multirow{3}{*}{ 관광 숙박업 } & \multirow{2}{*}{ 호텔업 } & 소형호텔업 & 추가 \\
\hline & & 의료관광호텔업 & 추가 \\
\hline & 일반관광숙박업 & 일반 야영장업 & 추가 \\
\hline $\begin{array}{l}\text { 관광 음식점 및 } \\
\text { 주점업 }\end{array}$ & 관광 주점업 & 관광 공연장업 & $\begin{array}{c}\text { 관광 음식점 및 주점업에서 } \\
\text { 문화, 오락 및 레저 } \\
\text { 스포츠산업으로 이동 }\end{array}$ \\
\hline $\begin{array}{c}\text { 여행사 및 여행보조 } \\
\text { 서비스업 }\end{array}$ & $\begin{array}{l}\text { 관광관련 전문기술 } \\
\text { 서비스업 }\end{array}$ & 관광 사진업 & $\begin{array}{c}\text { 부분 관광산업에서 } \\
\text { 핵심 관광산업으로 이동 }\end{array}$ \\
\hline \multirow{2}{*}{ 전문 및 종합휴양업 } & 전문휴양업 & 전문휴양업 & 추가 \\
\hline & 종합휴양업 & 종합휴양업 & 추가 \\
\hline
\end{tabular}

\section{나. 기타 검토 내용}

관광진흥법상 관광산업의 비교·분석 외에 한국표준산업분류 및 조사 적용 방안 등을 고려하여 기타 개정 내용을 도출하였다.

먼저 한국표준산업분류 10 차 개정 내용과 비교 분석해보면, 한국표준산업분류 10 차 개정에서 관광산업과 연관하여 가장 큰 변화는 면세점의 신설이다. 9차 한국 표준산업분류에는 기타 대형 종합소매업(47119)과 그 외 기타 종합소매업(47190) 에 포함되어 있던 면세점이 10 차 개정에서 신설되었다. 한국표준산업분류와 관광진 흥법에 모두 면세점이 포함되어 있으나, 각각에 포함되어 있는 사업체를 살펴보면, 포괄범위에는 차이가 있다. 관광진흥법상의 관광면세업은 「관세법」 제196조에 따 른 보세판매장의 특허를 받은 자 또는 「외국인관광객 등에 대한 부가가치세 및 개별 소비세 특례규정」 제5조에 따라 면세판매장의 지정을 받은 자가 판매시설을 갖추고 관광객에게 면세물품을 판매하는 업으로 사후면세점(Tax-Free)이 포함되어 있다. 그리고 한국표준산업분류의 면세업은 각종 상품을 종합적으로 취급하고 여행자에 게 부과되는 세금(소비세, 주세, 수입품 관세 등)을 면제하여 판매하는 산업 활동으 로 사전면세점(Duty-Free)이 포함되어 있다. 따라서 관광진흥법을 기준으로 한 기 존 관광사업체조사와의 시계열 유지 및 분석을 위해 면세점을 관광진흥법을 기준으 로 하는 관광면세점과 그 외의 일반면세점으로 세분화하는 것을 검토하였다. 
〈표 3-4〉 관광산업관련 한국표준산업분류 10 차 개정 내용

\begin{tabular}{|c|c|c|c|}
\hline \multicolumn{2}{|r|}{ 9차 한국표준산업분류 } & \multicolumn{2}{|r|}{10 차 한국표준산업분류 } \\
\hline \multirow{2}{*}{47119} & \multirow{2}{*}{ 기타 대형 종합소매업 } & 47119 & 기타 대형 종합소매업 \\
\hline & & 47130 & 면세점 \\
\hline 47190 & 그 외 기타 종합소매업 & 47190 & 그 외 기타 종합소매업 \\
\hline \multirow{2}{*}{49110} & \multirow{2}{*}{ 철도 운송업 } & 49101 & 철도 여객운송업 \\
\hline & & 49102 & 철도 화물운송업 \\
\hline 51100 & 정기 항공 운송업 & \multirow{2}{*}{51100} & \multirow{2}{*}{ 항공 여객운송업 } \\
\hline 51200 & 부정기 항공 운송업 & & \\
\hline 75992 & 전시 및 행사 대행업 & 75992 & 전시, 컨벤션 및 행사 대행업 \\
\hline
\end{tabular}

관광인증 쇼핑업, 관광인증 모텔업의 경우에는 인증 제도의 변화에 따라 인증과 비인증을 구별하지 않고 부분적용 관광산업으로 이동하였다. 즉, 핵심관광산업의 관광인증 쇼핑업, 관광인증 모텔업이 부분적용 관광산업의 관광 비인증 쇼핑업, 관 광 비인증 모텔업과 통합하여 부분적용 관광산업의 관광 쇼핑업과 모텔업으로 이동 을 검토하였다.

항공 정기 운송업과 항공 부정기 운송업은 9차 한국표준산업분류에서 별도로 구 분하고 있어 이를 관광산업특수분류에도 반영하였으나, 10 차 한국표준산업분류가 개정되면서 항공 정기 운송업과 항공 부정기 운송업이 통합되고 관광산업 측면에서 도 항공 운송업의 정기·부정기를 구별할 필요성이 없어 이를 통합하였다.

여행업은 관광진흥법상에 일반 여행업, 국외 여행업, 국내 여행업으로 구분하고 있으나, 많은 사업체가 국내여행업과 국외여행업을 동시 등록하여 영업하고 있는 특성을 반영하여 관광사업체기초통계조사에서는 국내외 여행업(국내여행업과 국외 여행업을 동시 등록)을 추가하여 조사하고 있어 국내외 여행업을 추가하여 별도로 분류하였다.

그리고 회의업과 관련된 산업으로 관광진흥법상에 정의되어 있는 국제회의 기획업 과 국제회의 시설업 외에 이벤트. 행사 기획 및 대행업의 신설과 관광진흥법에 주로 관광객 또는 관광사업자 등을 위하여 사업이나 시설 등을 운영하는 업인 관광지원서 비스업이 신설됨에 따라 상호의존 관광산업에 포함되어 있는 레저장비 임대업, 캠핑 카 임대업, 자동차 임대업 등의 핵심 관광산업으로의 이동이 추가로 검토되었다. 
〈표 3-5〉기타 검토 내용

\begin{tabular}{|c|c|c|c|}
\hline 중분류 & 소분류 & 세분류 & 검토 내용 \\
\hline \multirow[t]{2}{*}{ 관광 쇼핑업 } & 면세점 & 면세점 & $\begin{array}{c}\text { 관광 면세점과 } \\
\text { 일반 면세점으로 세분화 }\end{array}$ \\
\hline & 관광 인증 쇼핑업 & 관광 인증 쇼핑 & 부분적용 관광산업으로 이동 \\
\hline \multirow{2}{*}{ 관광 운수업 } & \multirow{2}{*}{ 관광 항공운송업 } & 관광 항공 정기운송업 & \multirow{2}{*}{$\begin{array}{c}\text { 관광 항공운송업으로 } \\
\text { 통합 }\end{array}$} \\
\hline & & 관광 항공 부정기운송업 & \\
\hline 관광 숙박업 & 일반 관광 숙박업 & 관광 인증 모텔업 & 부분적용 관광산업으로 이동 \\
\hline $\begin{array}{c}\text { 여행사 및 여행보조 } \\
\text { 서비스업 }\end{array}$ & 여행업 & 국내외 여행업 & 추가 \\
\hline
\end{tabular}

경제적 기여도, 파급효과 측면을 고려하여 연관·관련 산업을 포함하는 산업분류 에서 핵심산업은 관련 요소를 $100 \%$ 반영할 수 있는 산업으로 정의하고 있다. 관광 산업특수분류와 동일하게 4 개 대분류(핵심, 상호의존, 부분적용, 지원산업) 체계로 구축되어 있는 저작권산업특수분류를 활용한 경제기여도 조사에서도 핵심 저작권 산업은 $100 \%$, 그 외 대분류 산업은 별도의 조사를 통해 가중치를 산출하여 적용하 고 있다. 하지만 관광산업특수분류의 핵심 관광산업에는 관광 관련 요소가 $100 \%$ 에 가까운 산업도 존재하지만, $100 \%$ 는 아니지만 의존도가 높고 필수적인 산업도 포함 되어 있다. 이들 산업의 경우에는 별도의 관광비중 조사가 필요하며, 1 차적으로 기 존 관광산업특수분류에서 관광 인증 쇼핑업과 관광 음식점 및 주점업을 검토하였으 나 관광 인증 쇼핑업이 부분적용 관광산업으로의 이동이 검토되고 있어 분류코드 103 관광숙박업 內 분류코드 10304 일반 관광 숙박업의 관광비중 조사를 최종적으 로 고려한다. 해당 조사에서는 KSIC 기준의 '기타 일반 및 생활 숙박시설 운영업'과 '민박업'을 대상으로 설계 및 조사를 실시하고 기존에 핵심관광산업에 포함되었던 여관업(관광산업특수분류 관광 인증 모텔업)의 경우 핵심 관광산업에서 부분적용 관광산업으로 분류 이동에 따라 관광비중 조사 대상에서는 제외한다. 


\section{3. 전문가 의견조사}

본 연구에서는 관광산업특수분류 개정(안)을 도출하기 위해 전문가 의견조사를 진행하였다. 전문가 의견조사는 예측하고자 하는 문제에 대해 전문가들의 의견을 종합하고 정리하는 일련의 절차로 볼 수 있으며(이종성, 2001), 한 사람의 의견보다 두 사람의 의견이 더 정확하다는 전제에서 전문가로 구성된 패널을 이용한다.

전문가 의견 조사는 동일 대상자에게 몇 차례에 걸친 의견 수렴 과정을 거치게 된다. 전문가 의견 조사 횟수와 관련하여 Brockhoff(1975)는 조사의 정확도 측면 에서 3차 조사까지는 정확도가 증가하다가 4차 조사부터는 감소한다고 주장하였고, Delbecq et al.(1975)는 2 3차 델파이 조사면 충분하다고 제안하였다. 본 연구에 서는 1 차 전문가 자문회의를 통해 도출된 관광산업특수분류 개정(안)을 토대로 처 음부터 구조화된 설문지를 활용하여 2회에 걸쳐 전문가 의견 조사를 진행하였다. 전문가 의견조사에서 타당도는 Lawshe(1975)가 제시한 내용타당도 비율(Content Validity Ratio; CVR)을 기준으로 분석하였다. CVR은 각 항목(분류)에 대해 '중요 하다'라고 응답한 패널의 수에 따라 해당 최소값 이상이 되어야 해당 항목(분류)이 내용적 타당성이 확보되었다는 것을 의미한다.

$$
C V R=\frac{N_{e}-\frac{N}{2}}{\frac{N}{2}}
$$

여기서, $N_{e}$ 는 '중요하다'라고 응답한 패널의 수, $N$ 은 전체 패널의 수를 의미한다. 본 연구에서는 응답한 패널의 수가 10명으로〈표 3-6〉에서 제시한 것처럼 CVR 이 0.62 이상이면 내용타당도가 있는 것으로 판단하였다. 
〈표 3-6〉 응답한 패널의 수에 따른 내용타당도 비율(CVR)의 최소값

\begin{tabular}{|c|c|}
\hline 응답한 패널의 수 & 내용 타당도 비율(CVR) 최소값 \\
\hline 5 & 0.99 \\
\hline 6 & 0.99 \\
\hline 7 & 0.99 \\
\hline 8 & 0.75 \\
\hline 9 & 0.78 \\
\hline 10 & 0.62 \\
\hline 11 & 0.59 \\
\hline 12 & 0.56 \\
\hline 13 & 0.54 \\
\hline 14 & 0.51 \\
\hline 15 & 0.49 \\
\hline 20 & 0.42 \\
\hline 25 & 0.37 \\
\hline 30 & 0.33 \\
\hline 35 & 0.31 \\
\hline 40 & 0.29 \\
\hline
\end{tabular}

\section{가. 전문가 의견조사 패널 선정}

전문가 의견조사는 전문가들의 합의를 통하여 문제를 해결해 나가는 방법으로서 대표성을 가진 전문가 패널을 선정하는 것이 무엇보다도 중요하다(이종성, 2001). 본 연구에서는 대표성을 확보하기 위해 관광산업분류, 관광산업 파급 효과 분석 등의 관 련 전문가들 대상으로 학계, 연구기관, 정부기관으로 구분하여 패널을 구성하였다.

전문가 의견조사에서 패널의 수에 대한 명확한 규칙은 없다. Row\&Wright (2001)의 연구에서는 5명 20명을 권고하고 있으며, 최소 10명 이상(Dalky, 1969), 10 15명(Delbecq, 1975)의 패널 구성이 적합하다는 주장도 있다.

본 연구에서는 총 10 명을 전문가 패널로 구성하였으며, 각 패널에게 전자 우편을 통해 연구의 목적 및 내용, 조사 횟수, 조사결과의 익명성 보장 등에 관한 내용을 설명하였다. 
〈표 3-7〉 델파이 조사 패널 구성

\begin{tabular}{|c|c|c|}
\hline 구분 & 패널 & 패널 수(비율) \\
\hline 학계 & 정 $\bigcirc$, , 김 $0 \circ$, 잉, 심ㅇ, 잉 & 5명(50\%) \\
\hline 연구기관 & 심 $\bigcirc$, 정 $\bigcirc$, 강 & 5명(50\%) \\
\hline
\end{tabular}

\section{나. 1차 전문가 의견조사}

본 조사에서는 핵심관광산업에 해당하는 산업을 파악하고자 2012년에 마지막으 로 개정된 관광산업특수분류를 기준으로 핵심관광산업, 상호의존 관광산업, 부분적 용 관광산업에 포함되는 각각의 산업이 산업 환경 변화 등에 따라 현재에는 핵심관 광산업에 어느 정도 포함되는지를 살펴보았다. 이를 통해 향후 관광산업통계생산의 1 차 모집단이 되는 핵심관광산업을 재규정하는 작업을 실시하였다.

관광산업특수분류 4 영역에 포함되는 '관광지원산업'의 경우 주로 연구개발업, 관 광 공공기관, 관광 교육서비스업, 관광단체 등이 포함되어 핵심관광산업과의 연관 성이 낮아 조사에서는 제외시켰다. 관광산업특수분류 2 차 개정에는 포함되지 않았 으나 관광진흥법 개정에 따라 신설된 업종과 관광진흥법상 관광사업체에는 포함되 었으나 핵심관광산업에 포함되지 않은 업종에 대해서는 별도 항목을 구성하여 핵심 관광산업의 포함여부를 검토하였다. 1 차 전문가 조사의 분석결과는 다음과 같다.

핵심 관광산업(세분류기준 56개)의 경우 먼저 평균값을 기준으로 해당산업 해당 정 도에 대한 1 차 검증을 실시하였다. 1 차 검증결과 7점 척도에서 '핵심관광산업이다'의 기준이 되는 5점 미만에 해당되는 '경주장운영업'에 대해서는 재검토를 실시한다.

또한 평균값에서는 핵심관광산업에 포함되었으나 표준편차7)가 1.0 이상으로 크 게 나타났거나 내용타당도(CVR) 비율이 0.62 이하로 나타나 전문가의 의견을 조율 할 필요성이 있는 문항으로 '관광 인증 쇼핑업( $\mathrm{SD}=1.32)$ ', '관광 항공 정기운송업 ( $\mathrm{SD}=1.03)$ ', '민박업(SD=1.17)', '자동차 야영장업 $(\mathrm{SD}=1.23)$ ', '관광식당업( $\mathrm{SD}=1.26)$ ', '관광 유흥음식점업( $\mathrm{SD}=1.26)$ ', '관광 극장유흥업( $\mathrm{SD}=1.16)$ ', '관광 공연장업( $\mathrm{SD}=1.16)$ ', '외국인 전용 유흥음식점업( $\mathrm{SD}=1.16)$ ', '박물관 운영업(미술관 포함) (SD=1.06)', '사적지 관리 운영업( $\mathrm{SD}=1.16)$ ', '골프장 운영업( $\mathrm{SD}=1.18)$ ', '낚시장 운영업( $\mathrm{SD}=1.14)$ ',

7) 표준편차의 값이 0 이면 관측값 전체가 동일하다는 것을 의미하며 표준편차가 클수록 평균에서 떨어진 값이 많이 존재하게 된다. 이에 따라 데이터의 분산정도를 알 수 있다. 
'수상 오락 서비스업(SD=1.23)', '오락 및 관광체험시설 운영(SD=1.08)' 등에 대해 서도 2 차 전문가 조사를 통해 재검토를 진행하여 핵심 관광산업 해당여부에 대한 재검증을 실시한다.

〈표 3-8〉 핵심산업 대상 1차 전문가 조사 결과

\begin{tabular}{|c|c|c|c|c|c|c|c|c|c|c|c|c|c|}
\hline \multirow{2}{*}{$\begin{array}{l}\text { 핵심관광산업 } \\
\text { (세분류 기준) }\end{array}$} & \multicolumn{9}{|c|}{ 전문가 평가점수 } & & \multirow{2}{*}{ M } & \multirow{2}{*}{ SD } & \multirow{2}{*}{ CVR } \\
\hline & E1 & E2 & E3 & E4 & E5 & E6 & E7 & E8 & E9 & E10 & & & \\
\hline 면세점 & 7 & 6 & 6 & 6 & 6 & 7 & 6 & 7 & 6 & 6 & 6.30 & 0.48 & 1.0 \\
\hline $\begin{array}{c}\text { 외국인전용 } \\
\text { 관광기념품 판매업 }\end{array}$ & 7 & 7 & 7 & 7 & 7 & 7 & 6 & 7 & 4 & 7 & 6.60 & 0.97 & 0.8 \\
\hline 관광 인증 쇼핑업 & 6 & 5 & 7 & 7 & 3 & 6 & 5 & 7 & 5 & 7 & 5.80 & 1.32 & 0.8 \\
\hline 관광 철도운송업 & 7 & 7 & 6 & 6 & 6 & 5 & 5 & 7 & 7 & 7 & 6.30 & 0.82 & 1.0 \\
\hline 시내순환 관광업a & 7 & 7 & 6 & 5 & 7 & 7 & 6 & 6 & 6 & 6 & 6.30 & 0.67 & 1.0 \\
\hline 전세버스 운송업 & 6 & 5 & 7 & 6 & 5 & 5 & 6 & 6 & 7 & 6 & 5.90 & 0.74 & 1.0 \\
\hline 관광궤도업a & 7 & 7 & 7 & 7 & 7 & 7 & 7 & 7 & 5 & 6 & 6.70 & 0.67 & 1.0 \\
\hline 관광 유람선업 & 7 & 7 & 7 & 7 & 7 & 7 & 7 & 7 & 6 & 7 & 6.90 & 0.32 & 1.0 \\
\hline 크루즈업a & 7 & 7 & 7 & 7 & 7 & 7 & 7 & 7 & 7 & 7 & 7.00 & 0.00 & 1.0 \\
\hline 관광 항공 정기운송업 & 7 & 6 & 6 & 7 & 6 & 4 & 5 & 7 & 7 & 7 & 6.20 & 1.03 & 0.8 \\
\hline 관광 항공 부정기운송업 & 7 & 5 & 6 & 6 & 6 & 6 & 5 & 6 & 7 & 6 & 6.00 & 0.67 & 1.0 \\
\hline 관광 호텔업a & 7 & 7 & 7 & 7 & 7 & 7 & 7 & 7 & 7 & 7 & 7.00 & 0.00 & 1.0 \\
\hline 수상관광 호텔업a & 7 & 7 & 7 & 7 & 7 & 7 & 7 & 7 & 6 & 7 & 6.90 & 0.32 & 1.0 \\
\hline 한국전통 호텔업a & 7 & 7 & 7 & 7 & 7 & 7 & 7 & 7 & 6 & 7 & 6.90 & 0.32 & 1.0 \\
\hline 가족 호텔업a & 6 & 7 & 7 & 7 & 7 & 7 & 6 & 7 & 6 & 7 & 6.70 & 0.48 & 1.0 \\
\hline 호스텔업a & 7 & 7 & 7 & 7 & 7 & 7 & 6 & 7 & 6 & 7 & 6.80 & 0.42 & 1.0 \\
\hline 휴양콘도미니엄업a & 7 & 7 & 7 & 7 & 7 & 7 & 6 & 7 & 7 & 7 & 6.90 & 0.32 & 1.0 \\
\hline 관광 펜션업a & 6 & 7 & 7 & 7 & 7 & 7 & 6 & 7 & 7 & 7 & 6.80 & 0.42 & 1.0 \\
\hline 산림휴양림업 & 5 & 7 & 7 & 6 & 7 & 5 & 6 & 6 & 7 & 7 & 6.30 & 0.82 & 1.0 \\
\hline 게스트하우스 & 7 & 7 & 6 & 6 & 7 & 7 & 6 & 6 & 7 & 7 & 6.60 & 0.52 & 1.0 \\
\hline 레지던스 호텔 & 6 & 6 & 6 & 6 & 6 & 6 & 5 & 7 & 5 & 7 & 6.00 & 0.67 & 1.0 \\
\hline 관광 인증 모텔업 & 6 & 5 & 6 & 6 & 4 & 5 & 5 & 6 & 6 & 7 & 5.60 & 0.84 & 0.8 \\
\hline 민박업 & 5 & 7 & 6 & 5 & 4 & 4 & 6 & 6 & 4 & 7 & 5.40 & 1.17 & 0.4 \\
\hline $\begin{array}{l}\text { 외국인 관광 } \\
\text { 도시민박업a }\end{array}$ & 7 & 7 & 7 & 7 & 7 & 6 & 6 & 7 & 7 & 7 & 6.80 & 0.42 & 1.0 \\
\hline 자동차 야영장업a & 4 & 7 & 7 & 6 & 7 & 7 & 6 & 7 & 4 & 7 & 6.20 & 1.23 & 0.6 \\
\hline 한옥체험업a & 7 & 7 & 7 & 7 & 7 & 7 & 6 & 7 & 6 & 7 & 6.80 & 0.42 & 1.0 \\
\hline
\end{tabular}




\begin{tabular}{|c|c|c|c|c|c|c|c|c|c|c|c|c|c|}
\hline \multirow{2}{*}{$\begin{array}{l}\text { 핵심관광산업 } \\
\text { (세분류 기준) }\end{array}$} & \multicolumn{9}{|c|}{ 전문가 평가점수 } & \multirow[b]{2}{*}{ E10 } & \multirow{2}{*}{ M } & \multirow{2}{*}{ SD } & \multirow{2}{*}{ CVR } \\
\hline & E1 & E2 & E3 & E4 & E5 & E6 & E7 & E8 & E9 & & & & \\
\hline $\begin{array}{c}\text { 기타 관광 숙박시설 } \\
\text { 운영업 }\end{array}$ & 6 & 6 & 6 & 6 & 6 & 6 & 5 & 6 & 5 & 7 & 5.90 & 0.57 & 1.0 \\
\hline 관광 식당업a & 7 & 7 & 6 & 6 & 5 & 4 & 5 & 7 & 6 & 7 & 6.00 & 1.05 & 0.8 \\
\hline 관광 유흥음식점업a & 6 & 7 & 6 & 6 & 7 & 4 & 5 & 4 & 4 & 7 & 5.60 & 1.26 & 0.4 \\
\hline 관광 극장유흥업a & 5 & 7 & 6 & 5 & 7 & 4 & 5 & 4 & 4 & 6 & 5.30 & 1.16 & 0.4 \\
\hline 관광 공연장업a & 6 & 7 & 6 & 5 & 7 & 4 & 5 & 4 & 6 & 7 & 5.70 & 1.16 & 0.6 \\
\hline $\begin{array}{c}\text { 외국인전용 } \\
\text { 유흥음식점업a }\end{array}$ & 7 & 7 & 7 & 6 & 5 & 4 & 6 & 5 & 4 & 6 & 5.70 & 1.16 & 0.6 \\
\hline 일반 여행업a & 7 & 7 & 7 & 7 & 7 & 7 & 7 & 7 & 7 & 7 & 7.00 & 0.00 & 1.0 \\
\hline 국외 여행업a & 7 & 7 & 7 & 7 & 7 & 7 & 7 & 7 & 7 & 7 & 7.00 & 0.00 & 1.0 \\
\hline 국내 여행업a & 7 & 7 & 7 & 7 & 7 & 7 & 7 & 7 & 7 & 7 & 7.00 & 0.00 & 1.0 \\
\hline $\begin{array}{c}\text { 여행보조 및 예약 } \\
\text { 서비스업 }\end{array}$ & 6 & 7 & 6 & 6 & 7 & 7 & 7 & 7 & 7 & 7 & 6.70 & 0.48 & 1.0 \\
\hline 국제회의 기획업a & 7 & 7 & 6 & 7 & 7 & 6 & 6 & 7 & 6 & 7 & 6.60 & 0.52 & 1.0 \\
\hline 국제회의 시설업a & 7 & 7 & 6 & 7 & 7 & 6 & 6 & 7 & 6 & 7 & 6.60 & 0.52 & 1.0 \\
\hline $\begin{array}{l}\text { 박물관 운영업 } \\
\text { (미술관 포함) }\end{array}$ & 5 & 6 & 6 & 5 & 5 & 5 & 5 & 3 & 6 & 7 & 5.30 & 1.06 & 0.8 \\
\hline 사적지 관리 운영업 & 6 & 7 & 6 & 5 & 6 & 4 & 5 & 3 & 5 & 6 & 5.30 & 1.16 & 0.6 \\
\hline 식물원, 동물원 운영업 & 5 & 7 & 6 & 6 & 6 & 6 & 5 & 4 & 6 & 7 & 5.80 & 0.92 & 0.8 \\
\hline 자연공원 운영업 & 7 & 6 & 6 & 6 & 6 & 5 & 5 & 4 & 6 & 6 & 5.70 & 0.82 & 0.8 \\
\hline 기타 관광지 운영업 & 6 & 7 & 6 & 6 & 6 & 4 & 6 & 5 & 6 & 7 & 5.90 & 0.88 & 0.8 \\
\hline 종합유원시설업a & 7 & 7 & 7 & 7 & 7 & 7 & 6 & 5 & 7 & 7 & 6.70 & 0.67 & 1.0 \\
\hline 일반유원시설업a & 6 & 7 & 7 & 7 & 7 & 6 & 6 & 5 & 7 & 7 & 6.50 & 0.71 & 1.0 \\
\hline 기타유원시설업a & 5 & 7 & 7 & 7 & 7 & 7 & 6 & 5 & 7 & 7 & 6.50 & 0.85 & 1.0 \\
\hline $\begin{array}{c}\text { 농어촌 체험 및 } \\
\text { 생태 관광업 }\end{array}$ & 6 & 7 & 7 & 6 & 6 & 6 & 6 & 4 & 6 & 7 & 6.10 & 0.88 & 0.8 \\
\hline 관광 공연장업a & 6 & 5 & 6 & 6 & 7 & 6 & 6 & 4 & 6 & 7 & 5.90 & 0.88 & 0.8 \\
\hline 경주장 운영업 & 4 & 6 & 6 & 4 & 4 & 5 & 5 & 3 & 5 & 6 & 4.80 & 1.03 & 0.2 \\
\hline 골프장 운영업 & 4 & 7 & 6 & 7 & 5 & 5 & 5 & 4 & 5 & 7 & 5.50 & 1.18 & 0.6 \\
\hline 스키장 운영업 & 5 & 6 & 6 & 7 & 6 & 6 & 5 & 4 & 5 & 7 & 5.70 & 0.95 & 0.8 \\
\hline 낚시장 운영업 & 4 & 7 & 6 & 4 & 5 & 5 & 5 & 4 & 5 & 7 & 5.20 & 1.14 & 0.4 \\
\hline 수상 오락 서비스업 & 6 & 7 & 7 & 6 & 6 & 6 & 5 & 3 & 5 & 7 & 5.80 & 1.23 & 0.8 \\
\hline $\begin{array}{c}\text { 오락 및 관광체험시설 } \\
\text { 운영 }\end{array}$ & 6 & 6 & 6 & 6 & 6 & 5 & 5 & 3 & 5 & 7 & 5.50 & 1.08 & 0.8 \\
\hline 외국인 전용 카지노업a & 7 & 7 & 6 & 7 & 7 & 7 & 6 & 7 & 6 & 7 & 6.70 & 0.48 & 1.0 \\
\hline 내국인 출입 카지노업 & 6 & 7 & 6 & 7 & 6 & 7 & 6 & 7 & 4 & 7 & 6.30 & 0.95 & 0.8 \\
\hline
\end{tabular}

주: a code는 관광진흥법상 관광사업체 
상호의존 관광산업(세분류 기준 18 개)의 경우 평균값을 기준으로 핵심 관광산업 의 해당 정도에 대한 1 차 검증을 실시하였다. 1 차 검증결과 7 점 척도에서 '핵심관광 산업이다'의 기준이 되는 5점 이상에 포함되는 '여행자 보험업', ‘레저장비 임대업', '캠핑카 임대업'과 '관광용 자동차 임대업' 의 4 개 분류 대해서는 재검토를 실시한다.

〈표 3-9〉 상호의존 관광산업 대상 1 차 전문가 조사 결과

\begin{tabular}{|c|c|c|c|c|c|c|c|c|c|c|c|c|c|}
\hline \multirow{2}{*}{$\begin{array}{c}\text { 상호의존 관광산업 } \\
\text { (세분류 기준) }\end{array}$} & \multicolumn{9}{|c|}{ 전문가 평가점수 } & & \multirow{2}{*}{ M } & \multirow{2}{*}{ SD } & \multirow{2}{*}{ CVR } \\
\hline & E1 & E2 & E3 & E4 & E5 & E6 & E7 & E8 & E9 & E10 & & & \\
\hline $\begin{array}{c}\text { 상업 및 휴양건물 } \\
\text { 건설업 }\end{array}$ & 5 & 4 & 5 & 4 & 2 & 6 & 5 & 1 & 4 & 4 & 4.00 & 1.49 & -0.2 \\
\hline $\begin{array}{c}\text { 수송시설물 } \\
\text { 건설업(터미널) }\end{array}$ & 5 & 4 & 5 & 4 & 2 & 6 & 5 & 1 & 4 & 3 & 3.90 & 1.52 & -0.2 \\
\hline $\begin{array}{c}\text { 관광용지 개발조성 } \\
\text { 공사 }\end{array}$ & 5 & 5 & 5 & 4 & 2 & 6 & 6 & 1 & 4 & 5 & 4.30 & 1.64 & 0.2 \\
\hline $\begin{array}{l}\text { 관광지, 관광단지 또는 } \\
\text { 관광특구 조경 건설업 }\end{array}$ & 5 & 5 & 5 & 4 & 2 & 6 & 6 & 1 & 4 & 5 & 4.30 & 1.64 & 0.2 \\
\hline $\begin{array}{l}\text { 관광 관련 기타 } \\
\text { 토목시설물 건설업 }\end{array}$ & 5 & 5 & 5 & 4 & 2 & 6 & 6 & 1 & 4 & 5 & 4.30 & 1.64 & 0.2 \\
\hline 레저용 의복 소매업 & 5 & 3 & 5 & 4 & 2 & 2 & 5 & 3 & 4 & 6 & 3.90 & 1.37 & -0.2 \\
\hline $\begin{array}{c}\text { 레저 및 스포츠용품 } \\
\text { 소매업 }\end{array}$ & 5 & 4 & 5 & 4 & 3 & 2 & 5 & 5 & 5 & 6 & 4.40 & 1.17 & 0.2 \\
\hline $\begin{array}{l}\text { 자전거 및 기타 } \\
\text { 운송장비 소매업 }\end{array}$ & 5 & 3 & 5 & 4 & 2 & 3 & 5 & 3 & 5 & 6 & 4.10 & 1.29 & 0 \\
\hline $\begin{array}{c}\text { 관광용 가방 및 기타 } \\
\text { 가죽제품 소매업 }\end{array}$ & 5 & 5 & 5 & 4 & 2 & 2 & 5 & 4 & 5 & 6 & 4.30 & 1.34 & 0.2 \\
\hline 여행자 보험업 & 6 & 6 & 6 & 3 & 2 & 7 & 6 & 3 & 6 & 7 & 5.20 & 1.81 & 0.4 \\
\hline 여행자 수표 발행 & 6 & 5 & 7 & 3 & 2 & 4 & 6 & 3 & 4 & 7 & 4.70 & 1.77 & 0 \\
\hline 환전소 & 7 & 4 & 7 & 4 & 3 & 2 & 6 & 3 & 6 & 7 & 4.90 & 1.91 & 0 \\
\hline $\begin{array}{c}\text { 사진기 및 사진용품 } \\
\text { 소매업 }\end{array}$ & 5 & 4 & 5 & 3 & 2 & 2 & 5 & 3 & 4 & 6 & 3.90 & 1.37 & -0.2 \\
\hline 레저장비 임대업 & 6 & 4 & 7 & 4 & 5 & 4 & 5 & 4 & 5 & 6 & 5.00 & 1.05 & 0.2 \\
\hline 운송장비 임대업 & 6 & 3 & 7 & 3 & 3 & 4 & 5 & 3 & 4 & 6 & 4.40 & 1.51 & -0.2 \\
\hline 캠핑카 임대업 & 7 & 6 & 7 & 5 & 6 & 5 & 5 & 4 & 5 & 6 & 5.60 & 0.97 & 0.8 \\
\hline 관광용 자동차 임대업 & 7 & 6 & 7 & 5 & 4 & 5 & 5 & 4 & 5 & 6 & 5.40 & 1.07 & 0.6 \\
\hline 일반 자동차 임대업 & 6 & 4 & 7 & 2 & 4 & 2 & 4 & 4 & 4 & 5 & 4.20 & 1.55 & -0.4 \\
\hline
\end{tabular}


부분 관광산업(세분류 기준 19개)8)의 경우 ‘온라인상 여행정보제공'과 '관광지도 및 여행서적 출판업'의 평균값이 각각 $5.50,5.25$ 점으로 핵심관광산업으로의 이동 이 가능한 점수를 확보하였으나 응답의 표준편차가 1.60 과 1.58 로 나타났으며 내 용타당도 비율(CVR)도 응답한 패널 10 명 기준 0.62 이하로 나타나 해당 산업에 대해서는 2차 전문가 조사를 통한 재검증을 실시한다.

〈표 3-10〉부분 관광산업 대상 1차 전문가 조사 결과

\begin{tabular}{|c|c|c|c|c|c|c|c|c|c|c|c|c|c|}
\hline \multirow{2}{*}{$\begin{array}{l}\text { 부분 관광산업 } \\
\text { (세분류 기준) }\end{array}$} & \multicolumn{9}{|c|}{ 전문가 평가점수 } & & \multirow{2}{*}{$M$} & \multirow{2}{*}{ SD } & \multirow{2}{*}{ CVR } \\
\hline & E1 & E2 & E3 & E4 & E5 & E6 & E7 & E8 & E9 & E10 & & & \\
\hline 관광 비인증 쇼핑업 & 4 & 3 & 6 & 4 & 2 & 5 & 5 & 3 & 4 & 4 & 4.00 & 1.15 & -0.4 \\
\hline 도시간 철도 운송업 & 5 & 2 & 4 & 3 & 3 & 2 & 4 & 3 & 6 & 4 & 3.60 & 1.26 & -0.6 \\
\hline 도시내 철도 운송업 & 4 & 2 & 4 & 3 & 2 & 2 & 4 & 3 & 6 & 4 & 3.40 & 1.26 & -0.8 \\
\hline 관광보조 버스 운송업 & 5 & 4 & 4 & 4 & 3 & 6 & 4 & 3 & 5 & 4 & 4.20 & 0.92 & -0.4 \\
\hline 시내외버스 운송업 & 4 & 2 & 4 & 2 & 2 & 1 & 4 & 3 & 5 & 4 & 3.10 & 1.29 & -0.8 \\
\hline 택시 운송업 & 4 & 4 & 4 & 2 & 2 & 1 & 5 & 3 & 4 & 4 & 3.30 & 1.25 & -0.8 \\
\hline 수상운송업 & 4 & 5 & 4 & 3 & 3 & 5 & 5 & 3 & 4 & 5 & 4.10 & 0.88 & -0.2 \\
\hline $\begin{array}{c}\text { 내항-내륙 여객선 } \\
\text { 운송업 }\end{array}$ & 5 & 4 & 4 & 3 & 2 & 4 & 5 & 3 & 4 & 5 & 3.90 & 0.99 & -0.4 \\
\hline 청소년수련원 & 4 & 3 & 5 & 6 & 4 & 3 & 5 & 3 & 5 & 5 & 4.30 & 1.06 & 0 \\
\hline 관광 비인증 모텔업 & 7 & 2 & 5 & 4 & 2 & 2 & 5 & 3 & 5 & 5 & 4.00 & 1.70 & 0 \\
\hline 관광 일반음식점업 & 7 & 4 & 4 & 5 & 2 & 2 & 5 & 4 & 5 & 5 & 4.30 & 1.49 & 0 \\
\hline 비알콜 관광 음료점업 & 6 & 4 & 4 & 5 & 2 & 2 & 5 & 3 & 4 & 5 & 4.00 & 1.33 & -0.2 \\
\hline 기타 관광 주점업 & 5 & 4 & 4 & 5 & 2 & 2 & 5 & 3 & 5 & 5 & 4.00 & 1.25 & 0 \\
\hline 일반 공연시설 운영업 & 4 & 4 & 4 & 4 & 2 & 4 & 4 & 3 & 5 & 6 & 4.00 & 1.05 & -0.6 \\
\hline $\begin{array}{c}\text { 온라인상 } \\
\text { 여행정보제공 }\end{array}$ & 7 & 6 & 6 & 6 & 3 & 7 & 6 & 3 & 6 & 6 & 5.60 & 1.43 & 0.6 \\
\hline $\begin{array}{c}\text { 관광지도 및 여행서적 } \\
\text { 출판업 }\end{array}$ & 7 & 6 & 6 & 5 & 3 & 7 & 6 & 3 & 5 & 6 & 5.40 & 1.43 & 0.6 \\
\hline 통역 서비스업 & 5 & 4 & 6 & 4 & 2 & 7 & 5 & 3 & 4 & 6 & 4.60 & 1.51 & 0 \\
\hline 온천탕 & 5 & 3 & 6 & 6 & 3 & 6 & 5 & 3 & 5 & 5 & 4.70 & 1.25 & 0.4 \\
\hline $\begin{array}{l}\text { 그 외 기타 } \\
\text { 관광서비스업 }\end{array}$ & 5 & 4 & 6 & 5 & 2 & 4 & 5 & 3 & 5 & 5 & 4.40 & 1.17 & 0.2 \\
\hline
\end{tabular}

8) 상호의존 관광산업의 소분류 산업은 총 20 개이나 부분적용 관광사업체에 포함되어 있는 ‘관광사진업’에 대해서는 관광진흥법 신규 항목에 포함하여 설문을 진행함. 
관광진흥법상 새롭게 추가된 분류 및 관광진흥법상 관광사업체에는 포함되어 있 으나 핵심산업에서 제외된 사업체에 대한 핵심관광산업 포함여부에 대한 조사를 실 시하였다. 신규추가 검토항목은 평균값이 모두 6점 이상이며 표준편차와 내용타당 도에서도 포함 가능한 안정적인 수치가 나타났다. 다만 관광진흥법상 관광사업체에 포함되지만 핵심관광산업이 아닌 부분 관광산업에 있던 '관광사진업'의 경우 표준 편차와 내용타당도 모두 기준치에서 벗어나 재검증이 필요하다.

〈표 3-11〉 부분적용 관광산업 대상 1 차 전문가 조사 결과

\begin{tabular}{|c|c|c|c|c|c|c|c|c|c|c|c|c|c|}
\hline \multirow{2}{*}{$\begin{array}{l}\text { 신규추가 및 } \\
\text { 분류이동 관련 }\end{array}$} & \multicolumn{9}{|c|}{ 전문가 평가점수 } & & \multirow{2}{*}{ M } & \multirow{2}{*}{ SD } & \multirow{2}{*}{ CVR } \\
\hline & E1 & E2 & E3 & E4 & E5 & E6 & E7 & E8 & E9 & E10 & & & \\
\hline 소형호텔업 & 7 & 7 & 7 & 7 & 7 & 6 & 6 & 5 & 7 & 6 & 6.50 & 0.71 & 1.0 \\
\hline 의료관광호텔업 & 6 & 7 & 7 & 7 & 7 & 6 & 6 & 5 & 6 & 6 & 6.30 & 0.67 & 1.0 \\
\hline 일반 야영장업 & 5 & 7 & 6 & 7 & 7 & 5 & 6 & 6 & 5 & 6 & 6.00 & 0.82 & 1.0 \\
\hline 관광 사진업 & 6 & 7 & 6 & 6 & 5 & 3 & 6 & 3 & 5 & 5 & 5.20 & 1.32 & 0.6 \\
\hline 전문휴양업 & 6 & 7 & 7 & 7 & 7 & 7 & 6 & 6 & 6 & 6 & 6.50 & 0.53 & 1.0 \\
\hline 종합휴양업 & 6 & 7 & 7 & 7 & 7 & 7 & 6 & 6 & 6 & 6 & 6.50 & 0.53 & 1.0 \\
\hline
\end{tabular}

\section{다. 2 차 전문가 의견조사}

2차 전문가 의견조사에서는 1 차 전문가 의견조사(평균, 표준편차, 내용타당도 비 율)를 바탕으로 핵심관광산업 56 개 중 16 개, 상호의존 관광산업 18 개 중 4 개, 부분 관광산업 19 개 중 2 개, 신규추가 및 분류이동 6 개 중 1 개에 대한 2 차 의견을 수렴 하였다. 2차 전문가 조사 결과 핵심관광산업 가운데 '박물관운영업(미술관 포함)', ‘사적지 관리 운영업', ‘경주장 운영업’, ‘골프장 운영업', ‘낚시장 운영업’은 평균값 5점미만으로 핵심관광산업에 제외를 검토한다.

상호의존 관광산업에서는 '여행자 보험업, '캠핑카 임대업', '관광용 자동차 임대 업’의 3개 업종이 핵심관광산업으로 이동할 수 있는 평균값 5점 이상으로 나타나 3개 업종의 핵심관광산업 포함여부에 대해 검토한다.

마지막으로 기존 부분 관광산업에 포함되어 있던 '관광사진업’은 평균값이 5.20 으로 나타났으나 표준편차와 내용타당도 비율 모두 기준치 이상으로 나타나 전문가 자문회의 의견 등을 반영하여 핵심관광산업으로의 이동을 재검토한다. 
〈표 3-12〉 2차 전문가 조사 결과

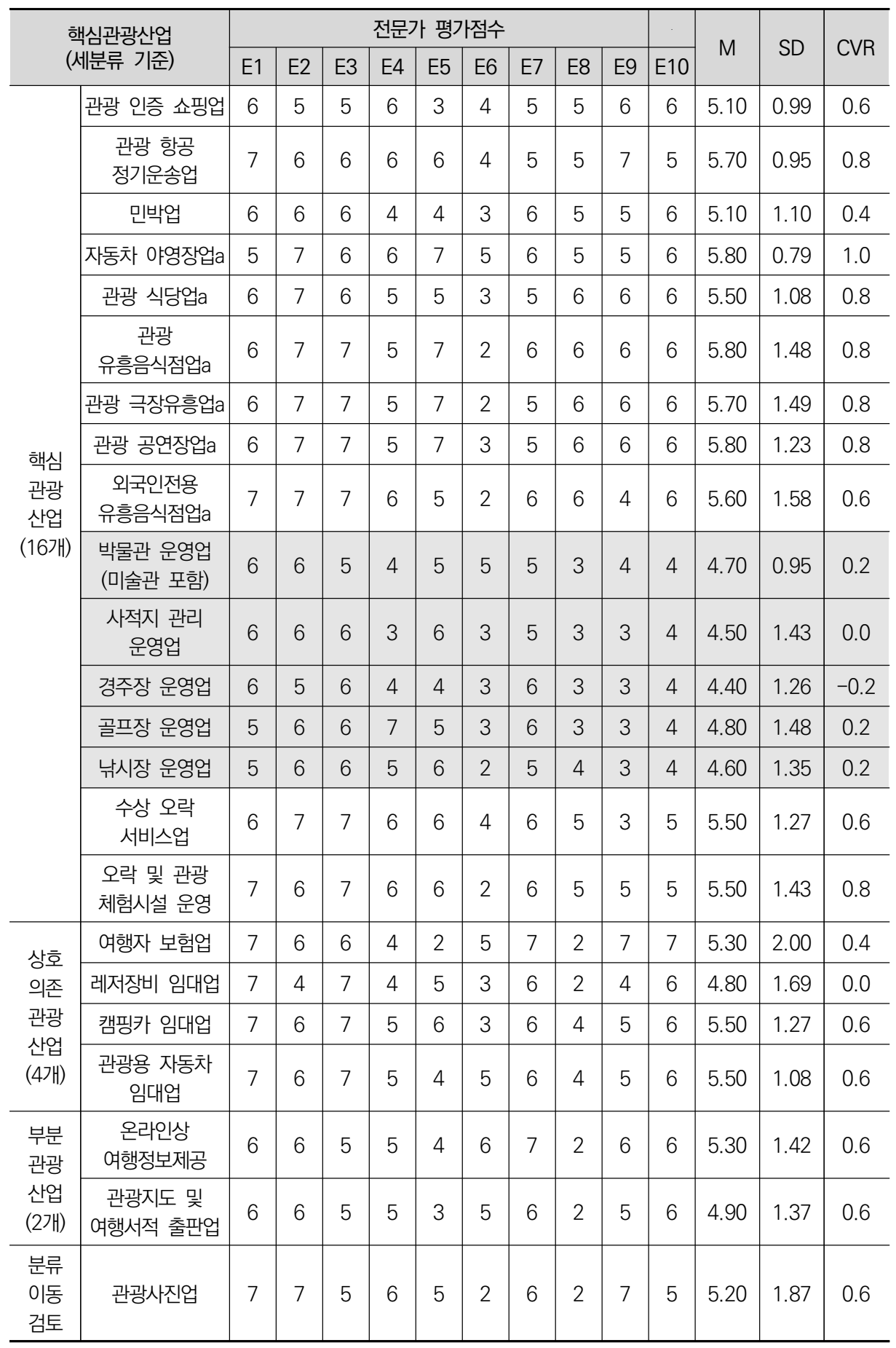

주: a code는 관광진흥법상 관광사업체 


\section{제3절 관광산업특수분류 개정 내용}

\section{1. 주요 개정 내용}

3 차 관광산업특수분류 주요 개정 내용은 다음과 같다. 기존에 2 차 관광산업특수 분류의 경우 2012년 이후 개정되지 않아 최근의 관광진흥법상 관광사업체에 대한 내용을 포괄하지 못하고 있다. 이에 본 3차 개정에서는 관광진흥법상의 신규 관광 사업 등 관광진흥법상의 관광산업과의 비교·분석을 통해 관광산업의 변화를 주요 개정 내용에 포함하였다.

첫 번째, 한국표준산업분류 10 차 개정에 따른 연계코드 변경작업을 통해 분류체 계의 매칭 작업을 실시하였다. 기존의 분류명이 변경된 내용과 새로운 분류명 신설 에 따라 기존 분류명을 변경한 내용을 정리하여 제시하였다.

두 번째, 기존에 관광산업특수분류에 포함되지 않았지만 관광진흥법의 개정에 따 라 신설된 산업을 새롭게 포함하였다. 신설된 추가 산업은 한국표준산업분류 코드 와 연계 가능하도록 하였다. 다만 분류 과정에서 $100 \%$ 연계되는 산업을 도출할 수 없으며 품목분석 과정에서 누락될 수 있는 사업체가 있기 때문에 향후 관광산업통 계 생산을 위한 조사를 위해서는 모집단에 대한 세부적인 검토가 필요할 것이다.

세 번째, 기존 관광산업특수분류의 분류체계 내에서의 산업별 이동을 실시하였 다. 기존에 상호의존 관광산업에 포함되었으나 관광진흥법 상 관광사업체에 포함된 경우 핵심관광산업으로의 이동을 고려하였다. 또한 관광진흥법 내에서 환경변화로 인해 삭제된 산업에 대해서는 핵심관광산업에 계속 존치시킬 것인가에 대한 여부를 판단하여 분류체계를 설정하였다. 다만 이러한 산업별 이동에 대한 통합적 공감대 형성을 위해서는 기존의 관광산업특수분류 체계의 연장선상에서의 개정이 아니라 $\mathrm{KSIC}$ 기준의 한국표준산업분류체계의 종합적인 검토를 통한 개정방안 마련이 필요 할 것이다. 


\section{2. 세부 개정 내용}

3차 관광산업특수분류 주요 개정 내을 기반으로 정리한 세부 개정 내용은 다음과 같다.

첫 번째, 한국표준산업분류 10 차 개정에 따라 새롭게 신설된 면세점(47130)의 경우 기존 슈퍼마켓(47121), 기타 대형 종합 소매업(47119), 그 외 기타 종합 소매 업(47190)을 통합하여 새로운 분류코드로 설정하였다. 9차 개정에서 정기 항공 운 송업(51100)과 부정기 항공 운송업(51200)으로 구분되어 있던 내용을 신분류 코드 인 항공 여객 운송업(51100)으로 통합하였다. 9차 개정에서 일반 음식점업(5611) 도 한식 음식점업(5611)과 외국식 음식점업(5612)로 변경하였다. 기타 호텔업 등 분류명은 동일하게 분류코드가 변경된 산업의 경우 10 차 개정을 기준으로 재정리하 였다.〈붙임파일 1 참고〉

두 번째, 기존에 관광산업특수분류에 포함되지 않았지만 관광진흥법의 개정에 따 라 신설된 산업의 적용이다. 먼저, 관광진흥법상의 관광산업에 포함되어 있으나 관 광산업특수분류에는 포함되어 있지 않았던 관광숙박업 내의 소형호텔업, 의료관광 호텔업을 검토하였다. 2 개의 산업은 분류체계로 포함이 가능하나 현재 신규로 추가 가능한 의료관광호텔업과 기존에 포함된 수상관광호텔업의 경우 사업체 수 자체가 0 이기 때문에 사업체 수를 기준으로 분류체계의 재설정을 통한 모집단 설정이 필요 하다. 야영장업의 경우 관광진흥법상 일반야영장업과 자동차 야영장업으로 구분되 어 조사되고 있으나 관광산업특수분류에서는 일반야영장업이 제외되어 있어 신규 항목 신설을 검토하였다.

세 번째, 기존 관광산업특수분류의 분류체계 내에서의 산업별 이동 및 통합 방안 을 검토하였다. 관광공연장업의 경우 관광산업특수분류 내에는 2 개의 분류체계로 해당 산업이 존재하고 있기 때문에 이를 통합하여 정리하는 방안을 마련하였다. 해 당산업의 주된 성격이 식사와 주류 판매가 아니라 공연이라는 점을 고려하여 중분 류 문화, 오락 및 레저 스포츠산업으로 이동하였다. 여객자동차 터미널시설업은 관 광산업특수분류에 포함되지 않았으나 관광진흥법상 해당 사업체의 수가 2 개에 불 과하기 때문에 새롭게 추가하는 방안에 대해 검토하였다. 또한 관광사진업은 관광 진흥법에 포함된 사업체이나 관광산업특수분류에서는 핵심관광산업이 아닌 부분관 
광산업에 포함되어 있어 분류체계 간 이동에 대한 부분을 검토하였다. 관광사진업 은 핵심 관광산업 중분류 여행사 및 여행보조 서비스업의 소분류 관광관련 전문기 술 서비스업으로 이동하였다. 외국인전용 관광기념품 판매업의 경우에는 관광진흥 법에서 2014년에 제외되었으나, 관광기념품 판매업은 관광산업특수분류 핵심관광 산업에서 중요한 부분으로 분류명 및 포괄범위를 변경하였다.

\section{3. 기존 분류와 비교}

관광산업특수분류 3 차 개정안은 앞서 제시한 주요 개정내용과 세부 개정 내용을 기준으로 다음과 같이 정리하였다. 해당 내용은 (1) 한국표준산업분류( KSIC) 10 차 개정과 (2) 관광진흥법상 관광산업의 신설 및 삭제, (3) 최근의 관광산업 변화에 따른 트렌드를 기준으로 전문가 인터뷰 및 의견조사 내용을 바탕으로 정리되었다. 해당 개정안의 경우 통계법 제22조(표준분류) 2항에 제시된바와 같이 향후 통계 작성 시 활용을 목적으로 작성된 내용이다. 다만 보다 포괄적인 공감대 형성 및 트렌드 반영 이 미흡한 부분에 대해서는 통계청과의 협의 및 추가적인 연구를 통해 보완해야 할 것으로 판단된다. 아래의 〈표 3-13〉은 관광산업특수분류 핵심관광산업의 개정(안) 에 대한 내용을 정리한 내용이다. 
〈표 3-13〉 최종 분류체계

\begin{tabular}{|c|c|c|c|c|}
\hline \multicolumn{2}{|c|}{ 세분류 기준 } & 1차 결과 & 2차 결과 & 최종 결과 \\
\hline \multirow{30}{*}{$\begin{array}{l}\text { 핵심 } \\
\text { 관광 } \\
\text { 산업 }\end{array}$} & 면세점 & $\bigcirc$ & $\bigcirc$ & $\begin{array}{c}\text { 핵심산업유지(관광면세점과 일반면세점으로 } \\
\text { 세분류 구분) }\end{array}$ \\
\hline & $\begin{array}{c}\text { 외국인전용 관광기념품 } \\
\text { 판매업 }\end{array}$ & $\bigcirc$ & $\bigcirc$ & $\begin{array}{c}\text { 핵심산업유지(관광진흥법상 삭제로 인해 } \\
\text { 관광기념품 판매업으로 분류명 변경) }\end{array}$ \\
\hline & 관광 인증 쇼핑업 & $\triangle$ & $x$ & $\begin{array}{c}\text { 핵심관광산업 제외 부분관광산업으로 } \\
\text { 이동(인증관련 업종) }\end{array}$ \\
\hline & 관광 철도운송업 & $\bigcirc$ & $\bigcirc$ & $\begin{array}{c}\text { 핵심산업유지(KSIC 개정에 따라 철도 } \\
\text { 여객운송업만 포함) }\end{array}$ \\
\hline & 시내순환 관광업a & $\bigcirc$ & $\bigcirc$ & 핵심산업유지 \\
\hline & 전세버스 운송업 & $\bigcirc$ & $\bigcirc$ & 핵심산업유지 \\
\hline & 관광궤도업a & $\bigcirc$ & $\bigcirc$ & 핵심산업유지 \\
\hline & 관광 유람선업a & 0 & $\bigcirc$ & 핵심산업유지 \\
\hline & 크루즈업a & $\bigcirc$ & $\bigcirc$ & 핵심산업유지 \\
\hline & 관광 항공 정기운송업 & $\triangle$ & $\bigcirc$ & \multirow{2}{*}{$\begin{array}{c}\text { 핵심산업유지(KSIC 개정에 따라 } \\
\text { 항공여객운송업만 포함) }\end{array}$} \\
\hline & 관광 항공 부정기운송업 & $\bigcirc$ & 0 & \\
\hline & 관광 호텔업a & $\bigcirc$ & $\bigcirc$ & 핵심산업유지 \\
\hline & 수상관광 호텔업a & $\bigcirc$ & $\bigcirc$ & 핵심산업유지 \\
\hline & 한국전통 호텔업a & $\bigcirc$ & $\bigcirc$ & 핵심산업유지 \\
\hline & 가족 호텔업a & $\bigcirc$ & $\bigcirc$ & 핵심산업유지 \\
\hline & 호스텔업a & $\bigcirc$ & $\bigcirc$ & 핵심산업유지 \\
\hline & 휴양콘도미니엄업a & 0 & $\bigcirc$ & 핵심산업유지 \\
\hline & 관광 펜션업a & $\bigcirc$ & $\bigcirc$ & 핵심산업유지 \\
\hline & 산림휴양림업 & 0 & $\bigcirc$ & 핵심산업유지 \\
\hline & 게스트하우스 & $\bigcirc$ & $\bigcirc$ & 핵심산업유지 \\
\hline & 레지던스 호텔 & $\bigcirc$ & $\bigcirc$ & 핵심산업유지 \\
\hline & 관광 인증 모텔업 & $\bigcirc$ & $x$ & $\begin{array}{c}\text { 핵심관광산업 제외 부분관광산업으로 } \\
\text { 이동(인증관련 업종) }\end{array}$ \\
\hline & 민박업 & $\triangle$ & $\bigcirc$ & 핵심산업유지 \\
\hline & 외국인 관광 도시민박업a & $\bigcirc$ & $\bigcirc$ & 핵심산업유지 \\
\hline & 자동차 야영장업a & $\triangle$ & $\bigcirc$ & 핵심산업유지 \\
\hline & 한옥체험업a & 0 & $\bigcirc$ & 핵심산업유지 \\
\hline & 기타 관광 숙박시설 운영업 & 0 & $\bigcirc$ & 핵심산업유지 \\
\hline & 관광 식당업a & $\triangle$ & $\bigcirc$ & 핵심산업유지 \\
\hline & 관광 유흥음식점업a & $\triangle$ & $\bigcirc$ & 핵심산업유지 \\
\hline & 관광 극장유흥업a & $\triangle$ & $\bigcirc$ & 핵심산업유지 \\
\hline
\end{tabular}




\begin{tabular}{|c|c|c|c|c|}
\hline & 세분류 기준 & 1차 결과 & 2차 결과 & 최종 결과 \\
\hline & 관광 공연장업a & $\triangle$ & $\bigcirc$ & $\begin{array}{c}\text { 핵심산업유지(관광음식점 및 주점업-> } \\
\text { 문화오락 및 레져스포츠 산업 중분류 이동) }\end{array}$ \\
\hline & 외국인전용 유흥음식점업a & $\triangle$ & $\bigcirc$ & 핵심산업유지 \\
\hline & 일반 여행업a & $\bigcirc$ & $\bigcirc$ & \\
\hline & 국외 여행업 & $\bigcirc$ & $\bigcirc$ & $\begin{array}{c}\text { 액심산법뉴시 } \\
\text { (세부류에 국내외 여핵업 추가) }\end{array}$ \\
\hline & 국내 여행업a & $\bigcirc$ & $\bigcirc$ & \\
\hline & 여행보조 및 예약 서비스업 & 0 & 0 & 핵심산업유지 \\
\hline & 국제회의 기획업a & $\bigcirc$ & $\bigcirc$ & 핵심산업유지 \\
\hline & 국제회의 시설업a & $\bigcirc$ & $\bigcirc$ & 핵심산업유지 \\
\hline & 박물관 운영업(미술관 포함) & $\triangle$ & $\times$ & 핵심산업 제외 \\
\hline & 사적지 관리 운영업 & $\triangle$ & $\times$ & 핵심산업 제외 \\
\hline & 식물원, 동물원 운영업 & $\bigcirc$ & $\bigcirc$ & 핵심산업유지 \\
\hline & 자연공원 운영업 & $\bigcirc$ & $\bigcirc$ & 핵심산업유지 \\
\hline & 기타 관광지 운영업 & $\bigcirc$ & $\bigcirc$ & 핵심산업유지 \\
\hline & 종합유원시설업a & $\bigcirc$ & $\bigcirc$ & 핵심산업유지 \\
\hline & 일반유원시설업a & $\bigcirc$ & $\bigcirc$ & 핵심산업유지 \\
\hline & 기타유원시설업a & $\bigcirc$ & $\bigcirc$ & 핵심산업유지 \\
\hline & 농어촌 체험 및 생태 관광업 & 0 & $\bigcirc$ & 핵심산업유지 \\
\hline & 관광 공연장업a & $\bigcirc$ & $\bigcirc$ & 핵심산업유지 \\
\hline & 경주장 운영업 & $\triangle$ & $\times$ & 핵심산업 제외 \\
\hline & 골프장 운영업 & $\triangle$ & $\times$ & 핵심산업 제외 \\
\hline & 스키장 운영업 & 0 & 0 & 핵심산업유지 \\
\hline & 낚시장 운영업 & $\triangle$ & $\times$ & 핵심산업 제외 \\
\hline & 수상 오락 서비스업 & $\triangle$ & $\bigcirc$ & 핵심산업유지 \\
\hline & 오락 및 관광체험시설 운영 & $\triangle$ & $\bigcirc$ & 핵심산업유지 \\
\hline & 외국인 전용 카지노업a & $\bigcirc$ & $\bigcirc$ & 핵심산업유지 \\
\hline & 내국인 출입 카지노업a & $\bigcirc$ & 0 & 핵심산업유지 \\
\hline & 상업 및 휴양건물 건설업 & $\times$ & $x$ & 포함안됨 \\
\hline & 수송시설물 건설업(터미널) & $x$ & $x$ & 포함안됨 \\
\hline 상호 & 관광용지 개발조성 공사 & $\times$ & $x$ & 포함안됨 \\
\hline $\begin{array}{l}\text { 의존 } \\
\text { 관광 }\end{array}$ & $\begin{array}{l}\text { 관광지, 관광단지 또는 } \\
\text { 관광특구 조경 건설업 }\end{array}$ & $\times$ & $x$ & 포함안됨 \\
\hline 산업 & $\begin{array}{c}\text { 관광 관련 기타 토목시설물 } \\
\text { 건설업 }\end{array}$ & $x$ & $x$ & 포함안됨 \\
\hline & 레저용 의복 소매업 & $\times$ & $\times$ & 포함안됨 \\
\hline & 레저 및 스포츠용품 소매업 & $\times$ & $x$ & 포함안됨 \\
\hline
\end{tabular}




\begin{tabular}{|c|c|c|c|c|}
\hline & 세분류 기준 & 1차 결과 & 2차 결과 & 최종 결과 \\
\hline & $\begin{array}{c}\text { 자전거 및 기타 운송장비 } \\
\text { 소매업 }\end{array}$ & $x$ & $x$ & 포함안됨 \\
\hline & $\begin{array}{c}\text { 관광용 가방 및 기타 } \\
\text { 가죽제품 소매업 }\end{array}$ & $x$ & $x$ & 포함안됨 \\
\hline & 여행자 보험업 & $\triangle$ & $\bigcirc$ & 핵심산업 포함 \\
\hline & 여행자 수표 발행 & $x$ & $x$ & 포함안됨 \\
\hline & 환전소 & $x$ & $x$ & 포함안됨 \\
\hline & 사진기 및 사진용품 소매업 & $x$ & $x$ & 포함안됨 \\
\hline & 레저장비 임대업 & $\triangle$ & $\times$ & 포함안됨 \\
\hline & 운송장비 임대업 & $x$ & $x$ & 포함안됨 \\
\hline & 캠핑카 임대업 & $\triangle$ & $\bigcirc$ & 핵심산업 포함 \\
\hline & 관광용 자동차 임대업 & $\triangle$ & $\bigcirc$ & 핵심산업 포함 \\
\hline & 일반 자동차 임대업 & $x$ & $\times$ & 포함안됨 \\
\hline & 관광 비인증 쇼핑업 & $x$ & $x$ & 포함안됨 \\
\hline & 도시간 철도 운송업 & $x$ & $x$ & 포함안됨 \\
\hline & 도시내 철도 운송업 & $x$ & $x$ & 포함안됨 \\
\hline & 관광보조 버스 운송업 & $x$ & $x$ & 포함안됨 \\
\hline & 시내외버스 운송업 & $\times$ & $x$ & 포함안됨 \\
\hline & 택시 운송업 & $x$ & $x$ & 포함안됨 \\
\hline & 수상운송업 & $x$ & $x$ & 포함안됨 \\
\hline & 내항-내륙 여객선 운송업 & $x$ & $x$ & 포함안됨 \\
\hline 부분 & 청소년수련원 & $x$ & $x$ & 포함안됨 \\
\hline $\begin{array}{l}\text { 놘형 } \\
\text { 사언 }\end{array}$ & 관광 비인증 모텔업 & $x$ & $x$ & 포함안됨 \\
\hline & 관광 일반음식점업 & $x$ & $x$ & 포함안됨 \\
\hline & 비알콜 관광 음료점업 & $x$ & $x$ & 포함안됨 \\
\hline & 기타 관광 주점업 & $x$ & $x$ & 포함안됨 \\
\hline & 일반 공연시설 운영업 & $x$ & $x$ & 포함안됨 \\
\hline & 온라인상 여행정보제공 & $\triangle$ & $\bigcirc$ & 핵심산업 포함 \\
\hline & 관광지도 및 여행서적 출판업 & $\triangle$ & $x$ & 포함안됨 \\
\hline & 통역 서비스업 & $x$ & $\times$ & 포함안됨 \\
\hline & 온천탕 & $x$ & $x$ & 포함안됨 \\
\hline & 그 외 기타 관광서비스업 & $x$ & $x$ & 포함안됨 \\
\hline
\end{tabular}




\begin{tabular}{|c|c|c|c|c|}
\hline \multicolumn{2}{|r|}{ 세분류 기준 } & 1차 결과 & 2차 결과 & 최종 결과 \\
\hline \multirow{6}{*}{$\begin{array}{l}\text { 신설 } \\
\text { 및 } \\
\text { 분류 } \\
\text { 이동 } \\
\text { 검토 }\end{array}$} & 소형호텔업 & $\bigcirc$ & $\bigcirc$ & $\begin{array}{l}\text { 관광진흥법 신설에 따른 포함 } \\
\text { (관광숙박업 중분류) }\end{array}$ \\
\hline & 의료관광호텔업 & 0 & $\bigcirc$ & $\begin{array}{c}\text { 관광진흥법 신설에 따른 포함 } \\
\text { (관광숙박업 중분류, 현재 운영업체 없음) }\end{array}$ \\
\hline & 일반야영장업 & $\bigcirc$ & $\bigcirc$ & $\begin{array}{l}\text { 관광진흥법 신설에 따른 포함 } \\
\text { (일반관광숙박업 중분류) }\end{array}$ \\
\hline & 관광사진업 & $\triangle$ & $\bigcirc$ & $\begin{array}{c}\text { 부분관광산업에서->핵심관광산업으로 } \\
\text { 대분류 이동(여행사 및 여행보조 } \\
\text { 서비스업 중분류 포함) }\end{array}$ \\
\hline & 전문휴양업 & $\bigcirc$ & $\bigcirc$ & $\begin{array}{c}\text { 관광진흥법 신설에 따른 모함 } \\
\text { (전문 및 종합휴양업 중분류 신설) }\end{array}$ \\
\hline & 종합휴양업 & $\bigcirc$ & $\bigcirc$ & $\begin{array}{c}\text { 관광진흥법 신설에 따른 포함 } \\
\text { (전문 및 종합휴양업 중분류 신설) }\end{array}$ \\
\hline
\end{tabular}



관광산업특수분류 개정안에 기초한 관광산업통계 생산방안 연구

제4장

관광산업통계

생산방안 



\section{제1절 관광산업특수분류 적용 모집단 구축}

\section{1. 관광산업특수분류 적용 모집단 정의}

\section{가. 목표모집단 정의}

목표모집단은 전국 17 개 지방자치단체의 관광산업과 관광산업특수분류코드 기준 모든 사업체이다. 아래 〈표 4-1〉는 관광산업특수분류 2차 개정을 기반으로 한 분류 체계이며 향후 3 차 개정이 확정될 경우 3 차 개정을 적용한 목표모집단을 재정의하 고 확대된 개념의 조사계획을 수립해야 한다.

〈표 4-1〉 관광산업특수분류 대분류별 세부 분류 현황

\begin{tabular}{l|c|c|c}
\hline \multirow{2}{*}{ 대분류 (1) } & \multicolumn{3}{|c}{ 관광산업특수분류 현황 } \\
\cline { 2 - 4 } & 중분류 (2) & 소분류 (3) & 세분류 (7) \\
\hline 1. 핵심 관광산업 & 8개 & 26개 & 56개 \\
\hline 2. 상호의존 관광산업 & 4개 & 11개 & 18 개 \\
\hline 3. 부분적용 관광산업 & 6개 & 11개 & 20개 \\
\hline 4. 관광 지원산업 & 4개 & 9개 & 12 개 \\
\hline 전체 & 22개 & 57개 & 106 개 \\
\hline
\end{tabular}

핵심 관광산업은 중분류가 8 개, 소분류 26 개, 세분류 56 개로 구성되어 있다. 나 머지 상호의존 관광산업, 부분적용 관광산업, 관광지원산업은 중분류 14 개, 소분류 31 개, 세분류 50 개로 구성되어 있다.

핵심관광산업과 부분적용관광산업은 관광진흥법상 관광산업과 유사한 형태를 나 타낸다. 반면 상호의존 관광산업과 관광지원산업의 경우는 관광산업보다는 향후 파 급력을 파악하기 위한 산업으로 구성되어 있기 때문에 “관광부문”을 규명하기 위한 추정방법론의 정립이 필요하다. 
〈표 4-2〉 관광산업특수분류 대분류별 사업특성별 모집단 현황

\begin{tabular}{|c|c|c|c|c|c|c|}
\hline \multirow[b]{2}{*}{ 대분류 } & \multicolumn{3}{|c|}{ 사업체수 } & \multicolumn{3}{|c|}{ 총 종사자수 } \\
\hline & $\begin{array}{l}\text { 관광진흥법 } \\
\text { 기준9) }\end{array}$ & $\begin{array}{l}\text { 관광산업 } \\
\text { 영위10) }\end{array}$ & $\begin{array}{l}\text { 관련 산업 } \\
\text { 전체 }\end{array}$ & $\begin{array}{l}\text { 관광진흥법 } \\
\quad \text { 기준 }\end{array}$ & $\begin{array}{l}\text { 관광산업 } \\
\text { 영위 }\end{array}$ & $\begin{array}{l}\text { 관련 산업 } \\
\text { 전체 }\end{array}$ \\
\hline 핵심 관광산업 & 49,350 & 42,638 & 77,705 & 308,241 & 334,367 & 530,915 \\
\hline 상호의존 관광산업 & - & 8,933 & 34,928 & - & 25,434 & 166,745 \\
\hline 부분적용 관광산업 & 3 & 94,901 & 578,678 & 22 & 231,441 & $1,814,121$ \\
\hline 관광 지원산업 & - & 580 & 31,542 & - & 16,378 & 418,564 \\
\hline 전체 & 49,353 & 147,052 & 722,853 & 308,263 & 607,620 & $2,930,345$ \\
\hline
\end{tabular}

관광산업특수분류 대분류별 관련 사업체수는 중복산업을11) 포함하여 전체 722,853 개이고 이 중에서 관광산업특수분류로 구분되는 사업이 연구원의 품목분석을 통해 구분되는 사업체는 중복산업을 포함하여 147,052 개이다. 관광진흥법 기준(관광진 흥법상 등록허가 신고 지정된 사업체와 $100 \%$ 일치하지는 않음)의 관광사업체는 49,353 개이다.

\section{나. 조사모집단 정의}

조사모집단은 통계청의『전국사업체조사』결과 중에서 주사업과 부사업 중에서 관광산업과 관광산업특수분류를 하나라도 영위하는 모든 사업체로 정의한다.

관광산업특수분류의 개정안에 따른 관광산업통계를 생산하기 위해 4단계의 조사 모집단을 정의하였다.

- 1단계: 관광산업특수분류 > 핵심관광산업 > 'a' 코드 기준

(단, 부분적용산업의 3 개 사업체 포함)

- 2단계: 관광산업특수분류 > 핵심관광산업 전체 사업체

- 3단계: 관광산업특수분류 > 품목분석 구분 사업체

- 4단계: 관광산업특수분류 > 전체 사업체

9) 관광산업특수분류 'a' 코드에 해당하는 사업체는 관광진흥법상 등록허가 신고 지정된 사업체와 $100 \%$ 일치 하지 않음

10) 연구진의 품목분석을 통해 1차 식별한 내용임

11) 1 개의 사업체가 복수의 관광산업을 영위하는 경우에 해당함 
각 4개 단계별 모집단에 대한 세부 정의내역은 다음과 같다.

[그림 4-1] 관광산업의 단계별 조사모집단 정의 절차

\begin{tabular}{|c|c|c|}
\hline $\begin{array}{l}\text { 【1단계 】 } \\
\text { 핵심관광산업의 } \\
\text { 'a'코드 기준 }\end{array}$ & $\Rightarrow$ & $\begin{array}{l}\text { - 관광산업특수분류의 ‘a’코드 기준을 대상으로 함( } 49,353 \text { 개) } \\
\text { - 사업자등록번호 등을 활용한 사업체 매치를 통해 최종 모집단 선정절차 } \\
\text { 가 필요함 (2018년 기준은 } 33,452 \text { 개) }\end{array}$ \\
\hline \multicolumn{3}{|r|}{ r } \\
\hline $\begin{array}{c}\text { 【2단계 】 } \\
\text { 핵심관광산업 전체 }\end{array}$ & $\Rightarrow$ & $\begin{array}{l}\text { - 관광산업특수분류의 대분류가 “핵심관광산업”을 가리킴 } \\
\text { - 2018년 기준 대분류가 핵심관광산업인 경우 } 77,705 \text { 개임 }\end{array}$ \\
\hline \multicolumn{3}{|l|}{$\downarrow$} \\
\hline $\begin{array}{l}\text { 【3단계 】 } \\
\text { 품복분석의 } \\
\text { 관광산업 구분 }\end{array}$ & $\Rightarrow$ & $\begin{array}{l}\text { - 관광산업의 범위 환대에 따라 전체 산업(핵심, 상호의존, 부분, 지원)을 } \\
\text { 대상으로 품목분석에서 '관광업’으로 구분한 사업체 } \\
\text { - 2018년 기준으로 연구원이 구분한 사업체는 } 147,052 \text { 개 } \\
\text { (단, 품목분석이 주산업 기준으로 구분되어 한계점을 가지고 있음) }\end{array}$ \\
\hline \multicolumn{3}{|r|}{ 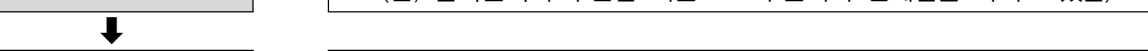 } \\
\hline $\begin{array}{l}\text { 【4단계 】 } \\
\text { 관광특수분류 전체 }\end{array}$ & $\Rightarrow$ & $\begin{array}{l}\text { - 관광산업의 전체 산업(핵심, 상호의존, 부분, 지원)에 대한 모든 사업체 } \\
\text { - 2018년 기준으로 전체 사업체는 } 722.853 \text { 개 } \\
\text { (단, 관광사업체를 식별하기 위한 관광비(ratio) 등을 검토 필요함) }\end{array}$ \\
\hline
\end{tabular}

전국사업체조사의 주사업과 부사업 중에서 관광산업과 관광산업특수분류를 하나 라도 영위하는 사업체에 대하여 관광특수분류 대분류 산업과 품목분석을 통해 관광 산업으로 구분되는 지의 여부를 기준으로 각 단계별 모집단 사업체를 파악하였고 이를 도식화하였다.

[그림 4-2] 관광산업의 단계별 조사모집단 현황

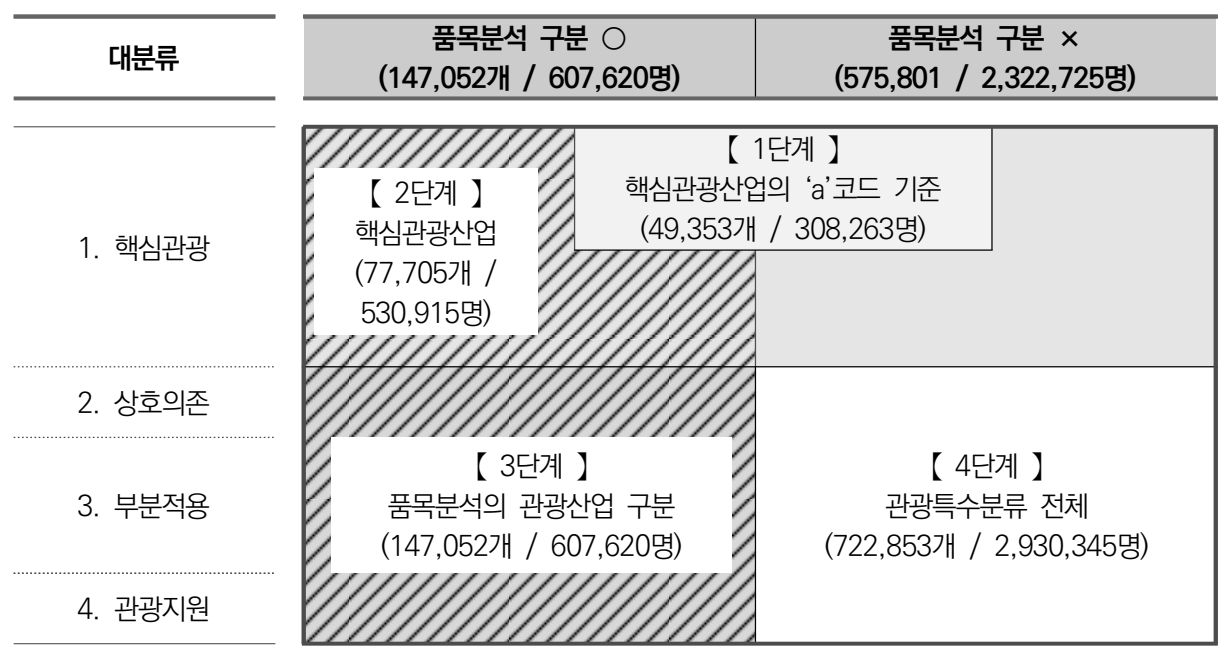


2018년 기준으로 1 단계는 49,353개, 2단계는 77,705개(1단계 대비 약 60\% 확대), 3 단계는 147,052 개(2단계 대비 약 $90 \%$ 확대), 4단계는 중복을 포함하여 722,853 개(3단계 대비 약 4.9배로 확대)가 된다.

단, 4 단계의 경우 전술한 바와 같이 실제 핵심과 부분적용 관광사업의 경우 관광 산업과 유사한 형태이며 상호의존과 관광지원산업은 관광산업보다는 향후 파급력 을 파악하기 위한 산업으로 구성되어 있다.

\section{2. 관광산업특수분류 적용 모집단 현황}

\section{가. 1 단계: 핵심관광산업의 'a'코드 기준}

관광산업특수분류 > 핵심관광산업 > 'a' 코드 기준 (단, 부분적용산업의 3 개 사업 체 포함) 사업체는 총 49,353 개소이다. 관광 음식점 및 주점업이 24,675 개소로 전 체의 50.0\%를 차지하고 있고 다음으로 관광숙박업이 23,344개소로 $25.01 \%$ 를 차 지하여 전체의 $75.01 \%$ 를 차지하고 있다. 종사자수의 비중도 전체의 $78.17 \%$ 를 차 지하고 있다.

〈표 4-3〉 기존 관광사업체의 관광산업특수분류별 모집단 현황

\begin{tabular}{c|c|c|c|c}
\hline \multirow{2}{*}{ 산업 중분류 } & \multicolumn{2}{|c|}{ 사업체 현황 } & \multicolumn{2}{c}{ 종사자수 현황 } \\
\cline { 2 - 5 } & 사업체수 (개) & 비중 & 종사자수 (명) & 비중 \\
\hline 관광 쇼핑업(도매업 제외) & 1,152 & $2.33 \%$ & 2,547 & $0.83 \%$ \\
\hline 관광 운수업 & 139 & $0.28 \%$ & 1,918 & $0.62 \%$ \\
\hline 관광 숙박업 & 12,344 & $25.01 \%$ & 88,363 & $28.66 \%$ \\
\hline 관광 음식점 및 주점업 & 24,675 & $50.00 \%$ & 152,633 & $49.51 \%$ \\
\hline 여행사 및 여행보조 서비스업 & 9,128 & $18.50 \%$ & 44,356 & $14.39 \%$ \\
\hline 국제회의업a & 339 & $0.69 \%$ & 4,713 & $1.53 \%$ \\
\hline 문화, 오락 및 레저 스포츠산업 & 1,573 & $3.19 \%$ & 13,711 & $4.45 \%$ \\
\hline 부분관광 기타 서비스업 & 3 & $0.01 \%$ & 22 & $0.01 \%$ \\
\hline 전체 & 49,353 & $100 \%$ & 308,263 & $100 \%$ \\
\hline
\end{tabular}

주1: 기존 관광산업특수분류 2차 개정에서는 외국인 전용 카지노업과 내국인 출입 카지노업이 핵심관광산업 'a' 코드로 지정되지 않아 3 차 개정에서는 포함 필요

주2: 부분관광 기타 서비스업에 포함된 '관광사진업’은 관광산업특수분류 3차 개정을 통해 핵심관광산업 '세분류'로 포함 하는 방안 제시 
‘a’코드 기준 중분류 산업별, 종사자수규모별 사업체수의 현황은 다음과 같다.

〈표 4-4〉 핵심관광산업의 'a'코드 기준 중분류 산업별, 규모에 따른 사업체수 현황

\begin{tabular}{|c|c|c|c|c|c|c|c|c|}
\hline \multirow{2}{*}{ 산업 중분류 } & \multicolumn{8}{|c|}{ 규모별 사업체 현황 } \\
\hline & 전체 & 1 4인 & 5 9인 & 10 19인 & 20 49인 & 50 99인 & 100 299인 & 300 인 이상 \\
\hline \multirow{2}{*}{$\begin{array}{l}\text { 관광 쇼핑업 } \\
\text { (도매업 제외) }\end{array}$} & 1,152 & 1,098 & 21 & 17 & 14 & 1 & 1 & - \\
\hline & $100 \%$ & $95.3 \%$ & $1.8 \%$ & $1.5 \%$ & $1.2 \%$ & $0.1 \%$ & $0.1 \%$ & - \\
\hline \multirow{2}{*}{ 관광 운수업 } & 139 & 48 & 27 & 31 & 28 & 3 & 2 & . \\
\hline & $100 \%$ & $34.5 \%$ & $19.4 \%$ & $22.3 \%$ & $20.1 \%$ & $2.2 \%$ & $1.4 \%$ & - \\
\hline \multirow{2}{*}{ 관광 숙박업 } & 12,344 & 10,919 & 436 & 374 & 343 & 127 & 108 & 37 \\
\hline & $100 \%$ & $88.5 \%$ & $3.5 \%$ & $3.0 \%$ & $2.8 \%$ & $1.0 \%$ & $0.9 \%$ & $0.3 \%$ \\
\hline \multirow{2}{*}{$\begin{array}{c}\text { 관광 음식점 및 } \\
\text { 주점업 }\end{array}$} & 24675 & 18263 & 3182 & 1531 & 1353 & 288 & 51 & 7 \\
\hline & $100 \%$ & $74.0 \%$ & $12.9 \%$ & $6.2 \%$ & $5.5 \%$ & $1.2 \%$ & $0.2 \%$ & $0.0 \%$ \\
\hline \multirow{2}{*}{$\begin{array}{c}\text { 여행사 및 여행보조 } \\
\text { 서비스업 }\end{array}$} & 9,128 & 7,427 & 1,015 & 362 & 246 & 49 & 22 & 7 \\
\hline & $100 \%$ & $81.4 \%$ & $11.1 \%$ & $4.0 \%$ & $2.7 \%$ & $0.5 \%$ & $0.2 \%$ & $0.1 \%$ \\
\hline \multirow{2}{*}{ 국제회의업 $a$} & 339 & 172 & 77 & 47 & 31 & 5 & 5 & 2 \\
\hline & $100 \%$ & $50.7 \%$ & $22.7 \%$ & $13.9 \%$ & $9.1 \%$ & $1.5 \%$ & $1.5 \%$ & $0.6 \%$ \\
\hline \multirow{2}{*}{$\begin{array}{c}\text { 문화, 오락 및 레저 } \\
\text { 스포츠산업 }\end{array}$} & 1,573 & 1,219 & 227 & 63 & 36 & 12 & 13 & 3 \\
\hline & $100 \%$ & $77.5 \%$ & $14.4 \%$ & $4.0 \%$ & $2.3 \%$ & $0.8 \%$ & $0.8 \%$ & $0.2 \%$ \\
\hline \multirow{2}{*}{$\begin{array}{c}\text { 부분관광 기타 } \\
\text { 서비스업 }\end{array}$} & 3 & 2 & & . & 1 & . & . & . \\
\hline & $100 \%$ & $66.7 \%$ & - & - & $33.3 \%$ & - & - & - \\
\hline \multirow{2}{*}{ 전체 } & 49,353 & 39,148 & 4,985 & 2,425 & 2,052 & 485 & 202 & 56 \\
\hline & $100 \%$ & $79.3 \%$ & $10.1 \%$ & $4.9 \%$ & $4.2 \%$ & $1.0 \%$ & $0.4 \%$ & $0.1 \%$ \\
\hline
\end{tabular}

'a'코드 기준 중분류 산업별, 종사자수규모별 종사자수의 현황은 다음과 같다.

〈표 4-5〉 핵심관광산업의 'a' 코드 기준 중분류 산업별, 규모에 따른 종사자수 현황

\begin{tabular}{|c|c|c|c|c|c|c|c|c|}
\hline \multirow{2}{*}{ 산업 중분류 } & \multicolumn{8}{|c|}{ 규모별 종사자수 현황 } \\
\hline & 전체 & 1 4인 & 5 9인 & 10 19인 & 20 49인 & 50 99인 & 100 299인 & 300 인 이싱 \\
\hline \multirow{2}{*}{$\begin{array}{l}\text { 관광 쇼핑업 } \\
\text { (도매업 제외) }\end{array}$} & 2,547 & 1,542 & 133 & 237 & 420 & 65 & 150 & \\
\hline & $100 \%$ & $60.5 \%$ & $5.2 \%$ & $9.3 \%$ & $16.5 \%$ & $2.6 \%$ & $5.9 \%$ & - \\
\hline \multirow{2}{*}{ 관광 운수업 } & 1,918 & 130 & 194 & 424 & 786 & 163 & 221 & . \\
\hline & $100 \%$ & $6.8 \%$ & $10.1 \%$ & $22.1 \%$ & $41.0 \%$ & $8.5 \%$ & $11.5 \%$ & - \\
\hline \multirow{2}{*}{ 관광 숙박업 } & 88,363 & 21,360 & 2,700 & 5,068 & 10,604 & 8,727 & 17,790 & 22,114 \\
\hline & $100 \%$ & $24.2 \%$ & $3.1 \%$ & $5.7 \%$ & $12.0 \%$ & $9.9 \%$ & $20.1 \%$ & $25.0 \%$ \\
\hline
\end{tabular}




\begin{tabular}{|c|c|c|c|c|c|c|c|c|}
\hline \multirow{2}{*}{ 산업 중분류 } & \multicolumn{8}{|c|}{ 규모별 종사자수 현황 } \\
\hline & 전체 & 1 4인 & 5 9인 & 10 19인 & 20 49인 & 50 99인 & 100 299인 & 300 인 이상 \\
\hline \multirow{2}{*}{$\begin{array}{c}\text { 관광 음식점 및 } \\
\text { 주점업 }\end{array}$} & 152633 & 41480 & 19481 & 22,521 & 39,605 & 18,427 & 7,536 & 3,583 \\
\hline & $100 \%$ & $27.2 \%$ & $12.8 \%$ & $14.8 \%$ & $25.9 \%$ & $12.1 \%$ & $4.9 \%$ & $2.3 \%$ \\
\hline \multirow{2}{*}{$\begin{array}{c}\text { 여행사 및 여행보조 } \\
\text { 서비스업 }\end{array}$} & 44,356 & 15,119 & 6,362 & 4,831 & 7,311 & 3,330 & 4,205 & 3,198 \\
\hline & $100 \%$ & $34.1 \%$ & $14.3 \%$ & $10.9 \%$ & $16.5 \%$ & $7.5 \%$ & $9.5 \%$ & $7.2 \%$ \\
\hline \multirow{2}{*}{ 국제회의업a } & 4,713 & 368 & 507 & 605 & 969 & 352 & 809 & 1,103 \\
\hline & $100 \%$ & $7.8 \%$ & $10.8 \%$ & $12.8 \%$ & $20.6 \%$ & $7.5 \%$ & $17.2 \%$ & $23.4 \%$ \\
\hline \multirow{2}{*}{$\begin{array}{c}\text { 문화, 오락 및 레저 } \\
\text { 스포츠산업 }\end{array}$} & 13,711 & 2,358 & 1,429 & 846 & 1,075 & 822 & 2,522 & 4,659 \\
\hline & $100 \%$ & $17.2 \%$ & $10.4 \%$ & $6.2 \%$ & $7.8 \%$ & $6.0 \%$ & $18.4 \%$ & $34.0 \%$ \\
\hline \multirow{2}{*}{$\begin{array}{c}\text { 부분관광 기타 } \\
\text { 서비스업 }\end{array}$} & 22 & 2 & - & - & 20 & - & - & - \\
\hline & $100 \%$ & $9.1 \%$ & - & - & $90.9 \%$ & - & - & - \\
\hline \multirow{2}{*}{ 전체 } & 308,263 & 82,359 & 30,806 & 34,532 & 60,790 & 31,886 & 33,233 & 34,657 \\
\hline & $100 \%$ & $26.7 \%$ & $10.0 \%$ & $11.2 \%$ & $19.7 \%$ & $10.3 \%$ & $10.8 \%$ & $11.2 \%$ \\
\hline
\end{tabular}

[그림 4-3] 핵심관광산업의 ' $a$ '코드 기준 규모별 사업체수 누적과 종사자수 누적과의 관계

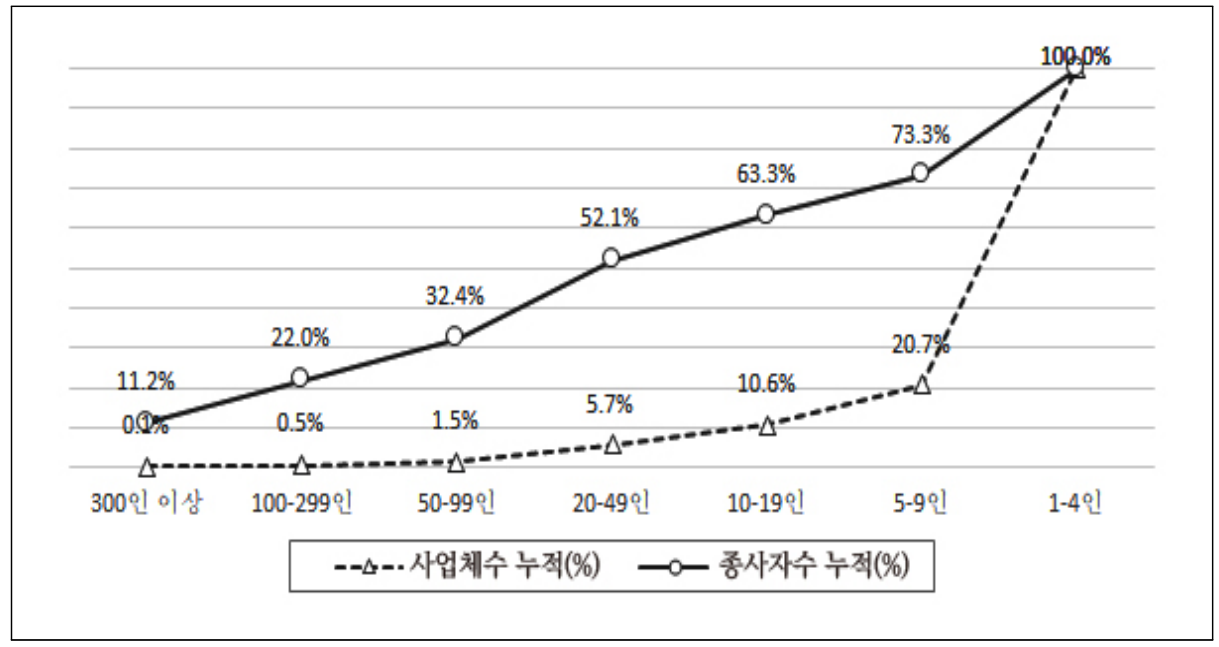

100 인 이상의 사업체수 누적비중은 $0.5 \%$ (258개/49,353개)를 차지하고 있고 종 사자수 누적비중은 22.0\%(67,890명/308,263명)에 해당하며 사업체당 평균 종사 자수는 263.1명(전체 평균은 6.25명)에 해당한다. 


\section{나. 2단계: 핵심관광산업 전체}

핵심관광산업의 사업체수는 모두 77,705 개소이다. 핵심관광산업의 'a' 코드 기준 의 사업체 현황과 마찬가지로 관광 음식점 및 주점업과 관광숙박업이 56,284 개소 로 $72.43 \%$ 를 차지하고 있다. 종사자수의 비중은 전체의 $54.11 \%$ 를 차지하고 있다.

〈표 4-6〉 핵심관광산업의 관광산업특수분류 모집단 현황

\begin{tabular}{c|c|c|c|c}
\hline \multirow{2}{*}{ 산업 중분류 } & \multicolumn{2}{|c|}{ 사업체 현황 } & \multicolumn{2}{c}{ 종사자수 현황 } \\
\cline { 2 - 5 } & 사업체수 (개) & 비중 & 종사자수 (명) & 비중 \\
\hline 관광 쇼핑업(도매업 제외) & 1,483 & $1.91 \%$ & 7,118 & $1.34 \%$ \\
\hline 관광 운수업 & 1,563 & $2.01 \%$ & 65,176 & $12.28 \%$ \\
\hline 관광 숙박업 & 31,609 & $40.68 \%$ & 134,639 & $25.36 \%$ \\
\hline 관광 음식점 및 주점업 & 24675 & $31.75 \%$ & 152,633 & $28.75 \%$ \\
\hline 여행사 및 여행보조 서비스업 & 10,099 & $13.00 \%$ & 49,870 & $9.39 \%$ \\
\hline 국제회의업a & 339 & $0.44 \%$ & 4,713 & $0.89 \%$ \\
\hline 문화, 오락 및 레저 스포츠산업 & 7,921 & $10.19 \%$ & 108,038 & $20.35 \%$ \\
\hline 카지노업a & 16 & $0.02 \%$ & 8,728 & $1.64 \%$ \\
\hline 전체 & 77,705 & $100 \%$ & 530,915 & $100 \%$ \\
\hline
\end{tabular}

중분류 산업별, 종사자수규모별 사업체수의 현황은 다음과 같다.

〈표 4-7〉 핵심관광산업의 중분류 산업별, 규모에 따른 사업체수 현황

\begin{tabular}{|c|c|c|c|c|c|c|c|c|}
\hline \multirow{2}{*}{ 산업 중분류 } & \multicolumn{8}{|c|}{ 규모별 사업체 현황 } \\
\hline & 전체 & 1 4인 & 5 9인 & 10 19인 & 20 49인 & 50 99인 & 100 299인 & 300 인 이상 \\
\hline \multirow{2}{*}{$\begin{array}{l}\text { 관광 쇼핑업 } \\
\text { (도매업 제외) }\end{array}$} & 1,483 & 1,354 & 43 & 31 & 28 & 14 & 11 & 2 \\
\hline & $100 \%$ & $91.3 \%$ & $2.9 \%$ & $2.1 \%$ & $1.9 \%$ & $0.9 \%$ & $0.7 \%$ & $0.1 \%$ \\
\hline \multirow{2}{*}{ 관광 운수업 } & 1,563 & 264 & 217 & 364 & 571 & 114 & 21 & 12 \\
\hline & $100 \%$ & $16.9 \%$ & $13.9 \%$ & $23.3 \%$ & $36.5 \%$ & $7.3 \%$ & $1.3 \%$ & $0.8 \%$ \\
\hline \multirow{2}{*}{ 관광 숙박업 } & 31,609 & 28,539 & 1,831 & 595 & 366 & 132 & 109 & 37 \\
\hline & $100 \%$ & $90.3 \%$ & $5.8 \%$ & $1.9 \%$ & $1.2 \%$ & $0.4 \%$ & $0.3 \%$ & $0.1 \%$ \\
\hline \multirow{2}{*}{$\begin{array}{c}\text { 관광 음식점 및 } \\
\text { 주점업 }\end{array}$} & 24,675 & 18,263 & 3,182 & 1,531 & 1,353 & 288 & 51 & 7 \\
\hline & $100 \%$ & $74.0 \%$ & $12.9 \%$ & $6.2 \%$ & $5.5 \%$ & $1.2 \%$ & $0.2 \%$ & $0.0 \%$ \\
\hline \multirow{2}{*}{$\begin{array}{c}\text { 여행사 및 여행보조 } \\
\text { 서비스업 }\end{array}$} & 10,099 & 8,192 & 1,133 & 412 & 271 & 55 & 28 & 8 \\
\hline & $100 \%$ & $81.1 \%$ & $11.2 \%$ & $4.1 \%$ & $2.7 \%$ & $0.5 \%$ & $0.3 \%$ & $0.1 \%$ \\
\hline \multirow{2}{*}{ 국제회의업a } & 339 & 172 & 77 & 47 & 31 & 5 & 5 & 2 \\
\hline & $100 \%$ & $50.7 \%$ & $22.7 \%$ & $13.9 \%$ & $9.1 \%$ & $1.5 \%$ & $1.5 \%$ & $0.6 \%$ \\
\hline \multirow{2}{*}{$\begin{array}{c}\text { 문화, 오락 및 레저 } \\
\text { 스포츠산업 }\end{array}$} & 7,921 & 5,438 & 1,095 & 496 & 392 & 204 & 271 & 25 \\
\hline & $100 \%$ & $68.7 \%$ & $13.8 \%$ & $6.3 \%$ & $4.9 \%$ & $2.6 \%$ & $3.4 \%$ & $0.3 \%$ \\
\hline \multirow{2}{*}{ 카지노업a } & 16 & - & - & - & - & - & 9 & 7 \\
\hline & $100 \%$ & - & - & - & - & - & $56.3 \%$ & $43.8 \%$ \\
\hline \multirow{2}{*}{ 전체 } & 77,705 & 62,222 & 7,578 & 3,476 & 3,012 & 812 & 505 & 100 \\
\hline & $100 \%$ & $80.1 \%$ & $9.8 \%$ & $4.5 \%$ & $3.9 \%$ & $1.0 \%$ & $0.6 \%$ & $0.1 \%$ \\
\hline
\end{tabular}


중분류 산업별, 종사자수규모별 종사자수의 현황은 다음과 같다.

〈표 4-8〉 핵심관광산업의 중분류 산업별, 규모에 따른 종사자수 현황

\begin{tabular}{|c|c|c|c|c|c|c|c|c|}
\hline \multirow{2}{*}{ 산업 중분류 } & \multicolumn{8}{|c|}{ 규모별 종사자수 현황 } \\
\hline & 전체 & 1 4인 & 5 9인 & 10 19인 & 20 49인 & 50 99인 & 100 299인 & 300 인 이상 \\
\hline \multirow{2}{*}{$\begin{array}{l}\text { 관광 쇼핑업 } \\
\text { (도매업 제외) }\end{array}$} & 7,118 & 1,957 & 287 & 429 & 825 & 1,053 & 1,695 & 872 \\
\hline & $100 \%$ & $27.5 \%$ & $4.0 \%$ & $6.0 \%$ & $11.6 \%$ & $14.8 \%$ & $23.8 \%$ & $12.3 \%$ \\
\hline \multirow{2}{*}{ 관광 운수업 } & 65,176 & 605 & 1,492 & 5,121 & 17,544 & 7,229 & 2,639 & 30,546 \\
\hline & $100 \%$ & $0.9 \%$ & $2.3 \%$ & $7.9 \%$ & $26.9 \%$ & $11.1 \%$ & $4.0 \%$ & $46.9 \%$ \\
\hline \multirow{2}{*}{ 관광 숙박업 } & 134,639 & 55,392 & 11,192 & 7,812 & 11,186 & 9,053 & 17,890 & 22,114 \\
\hline & $100 \%$ & $41.1 \%$ & $8.3 \%$ & $5.8 \%$ & $8.3 \%$ & $6.7 \%$ & $13.3 \%$ & $16.4 \%$ \\
\hline \multirow{2}{*}{$\begin{array}{c}\text { 관광 음식점 및 } \\
\text { 주점업 }\end{array}$} & 152633 & 41,480 & 19481 & 22,521 & 39,605 & 18,427 & 7,536 & 3,583 \\
\hline & $100 \%$ & $27.2 \%$ & $12.8 \%$ & $14.8 \%$ & $25.9 \%$ & $12.1 \%$ & $4.9 \%$ & $2.3 \%$ \\
\hline \multirow{2}{*}{$\begin{array}{c}\text { 여행사 및 여행보조 } \\
\text { 서비스업 }\end{array}$} & 49,870 & 16,616 & 7,105 & 5,485 & 8,080 & 3,755 & 5,064 & 3,765 \\
\hline & $100 \%$ & $33.3 \%$ & $14.2 \%$ & $11.0 \%$ & $16.2 \%$ & $7.5 \%$ & $10.2 \%$ & $7.5 \%$ \\
\hline \multirow{2}{*}{ 국제회의업a } & 4,713 & 368 & 507 & 605 & 969 & 352 & 809 & 1,103 \\
\hline & $100 \%$ & $7.8 \%$ & $10.8 \%$ & $12.8 \%$ & $20.6 \%$ & $7.5 \%$ & $17.2 \%$ & $23.4 \%$ \\
\hline \multirow{2}{*}{$\begin{array}{c}\text { 문화, 오락 및 레저 } \\
\text { 스포츠산업 }\end{array}$} & 108,038 & 10,786 & 7,058 & 6,642 & 11,868 & 14,915 & 40,795 & 15,974 \\
\hline & $100 \%$ & $10.0 \%$ & $6.5 \%$ & $6.1 \%$ & $11.0 \%$ & $13.8 \%$ & $37.8 \%$ & $14.8 \%$ \\
\hline \multirow{2}{*}{ 카지노업a } & 8728 & - & - & - & - & - & 1,471 & 7,257 \\
\hline & $100 \%$ & - & - & - & - & - & $16.9 \%$ & $83.1 \%$ \\
\hline \multirow{2}{*}{ 전체 } & 530,915 & 127,204 & 47,122 & 48,615 & 90,077 & 54,784 & 77,899 & 85,214 \\
\hline & $100 \%$ & $24.0 \%$ & $8.9 \%$ & $9.2 \%$ & $17.0 \%$ & $10.3 \%$ & $14.7 \%$ & $16.1 \%$ \\
\hline
\end{tabular}

[그림 4-4] 핵심관광산업 규모별 사업체수 누적과 종사자수 누적과의 관계

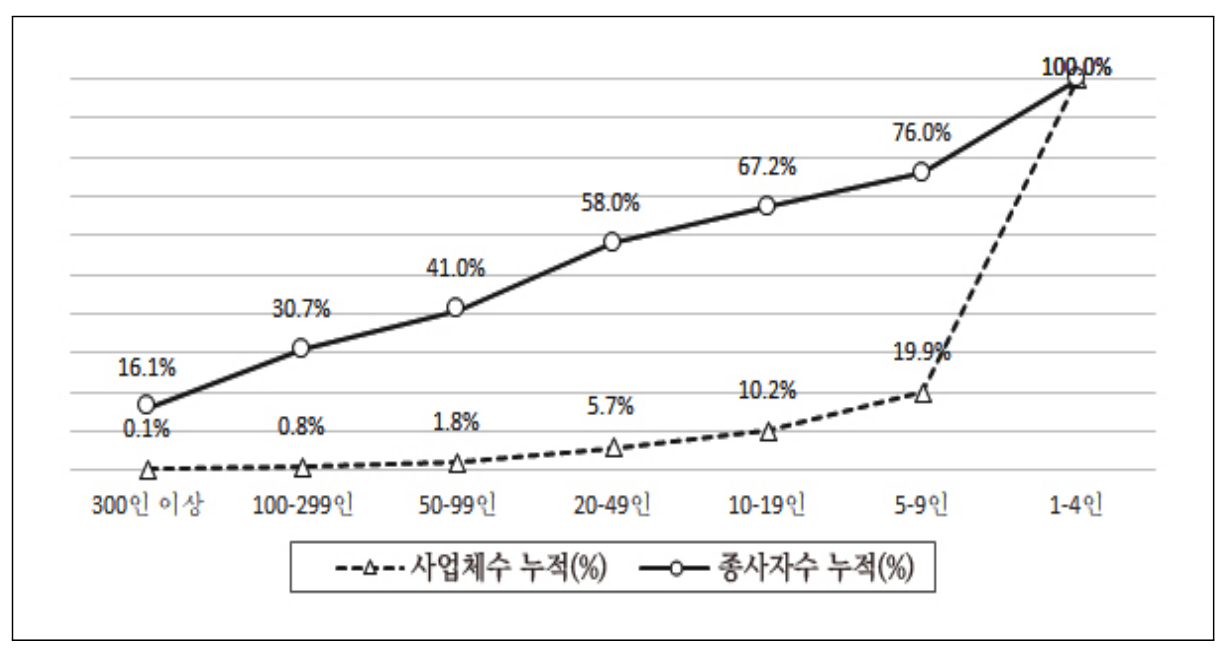


100 인 이상의 사업체수 누적비중은 $0.8 \%(605$ 개/ 77,705 개)를 차지하고 있고 종 사자수 누적비중은 $30.7 \%(163,113$ 명/530,915명)에 해당하며 사업체당 평균 종사 자수는 269.6명(전체 평균은 6.83명)에 해당한다.

\section{다. 3단계: 품목분석의 관광산업 기준}

품목분석의 관광산업 기준 전체 사업체는 147,052 개 사업체이다.

핵심 관광산업과 부분적용 관광산업은 137,539 개로 $93.5 \%$ 를 차지하고 있고 종 사자수는 565,808 명으로 $93.1 \%$ 를 차지하고 있다. 상호의존 관광산업과 관광 지원 산업의 경우 사업체는 각각 8,933 개, 580 개이고 종사자수는 25,434 명, 16,378 명 을 나타내고 있다.

〈표 4-9〉 품목분석의 관광산업 기준의 모집단 현황

\begin{tabular}{|c|c|c|c|c|c|}
\hline \multirow{2}{*}{ 대분류 } & \multirow{2}{*}{ 중분류 } & \multicolumn{2}{|c|}{ 사업체 현황 } & \multicolumn{2}{|c|}{ 종사자수 현황 } \\
\hline & & 사업체수(개) & 비중 & 종사자수 (명) & 비중 \\
\hline \multirow{9}{*}{$\begin{array}{l}\text { 핵심 } \\
\text { 관광 } \\
\text { 산업 }\end{array}$} & 소계 & 42,638 & $29.00 \%$ & 334,367 & $55.03 \%$ \\
\hline & 관광 쇼핑업(도매업 제외) & 1,237 & $0.84 \%$ & 6,453 & $1.06 \%$ \\
\hline & 관광 운수업 & 1,420 & $0.97 \%$ & 59,330 & $9.76 \%$ \\
\hline & 관광 숙박업 & 24,107 & $16.39 \%$ & 109,991 & $18.10 \%$ \\
\hline & 관광 음식점 및 주점업 & 1,468 & $1.00 \%$ & 9,962 & $1.64 \%$ \\
\hline & 여행사 및 여행보조 서비스업 & 6,780 & $4.61 \%$ & 33,066 & $5.44 \%$ \\
\hline & 국제회의업a & 219 & $0.15 \%$ & 3,559 & $0.59 \%$ \\
\hline & 문화, 오락 및 레저 스포츠산업 & 7,391 & $5.03 \%$ & 103,278 & $17.00 \%$ \\
\hline & 카지노업a & 16 & $0.01 \%$ & 8,728 & $1.44 \%$ \\
\hline \multirow{5}{*}{$\begin{array}{l}\text { 상호 } \\
\text { 의존 } \\
\text { 관광 } \\
\text { 산업 }\end{array}$} & 소계 & 8,933 & $6.07 \%$ & 25,434 & $4.19 \%$ \\
\hline & 관광 건설업 & 192 & $0.13 \%$ & 2,684 & $0.44 \%$ \\
\hline & 관광 및 레저용품 소매업 & 3,962 & $2.69 \%$ & 6,374 & $1.05 \%$ \\
\hline & 관광 보험 및 금융서비스업 & 511 & $0.35 \%$ & 1,029 & $0.17 \%$ \\
\hline & 레저장비업 & 4,268 & $2.90 \%$ & 15,347 & $2.53 \%$ \\
\hline \multirow{7}{*}{$\begin{array}{l}\text { 부분 } \\
\text { 적용 } \\
\text { 관광 } \\
\text { 산업 }\end{array}$} & 소계 & 94,901 & $64.54 \%$ & 231,441 & $38.09 \%$ \\
\hline & 관광 비인증 쇼핑업 & 5 & $0.00 \%$ & 22 & $0.00 \%$ \\
\hline & 부분관광 운송업 & 1,138 & $0.77 \%$ & 22,866 & $3.76 \%$ \\
\hline & 부분관광 숙박업 & 15,604 & $10.61 \%$ & 41,285 & $6.79 \%$ \\
\hline & 부분관광 음식점 및 주점업 & 77,393 & $52.63 \%$ & 159,816 & $26.30 \%$ \\
\hline & 부분관광 공연장업 & 337 & $0.23 \%$ & 1,030 & $0.17 \%$ \\
\hline & 부분관광 기타 서비스업 & 424 & $0.29 \%$ & 6,422 & $1.06 \%$ \\
\hline
\end{tabular}




\begin{tabular}{c|c|c|c|c|c}
\hline \multirow{2}{*}{ 대분류 } & \multirow{2}{*}{ 중분류 } & \multicolumn{2}{|c|}{ 사업체 현황 } & \multicolumn{2}{|c}{ 종사자수 현황 } \\
\cline { 3 - 6 } & & 사업체수(개) & 비중 & 종사자수 (명) & 비중 \\
\hline \multirow{4}{*}{ 관광 } & 소계 & 580 & $0.39 \%$ & 16,378 & $2.70 \%$ \\
지원 & 관광 연구 개발업 & 26 & $0.02 \%$ & 847 & $0.14 \%$ \\
\cline { 2 - 6 } 산업 & 관광 공공기관 & 193 & $0.13 \%$ & 13,546 & $2.23 \%$ \\
\cline { 2 - 6 } & 관광 교육서비스업 & 155 & $0.11 \%$ & 1,244 & $0.20 \%$ \\
\cline { 2 - 6 } & 관광 단체 & 206 & $0.14 \%$ & 741 & $0.12 \%$ \\
\hline \multicolumn{2}{r|}{} & 147,052 & $100 \%$ & 607,620 & $100 \%$ \\
\hline
\end{tabular}

사업체수는 전체 147,052 개 중에서 1 4인이 전체의 90.0\%로 132,401개이고 100 인 이상은 613 개로 $0.4 \%$ 를 차지하고 있다. 중분류 산업별, 종사자수규모별 사 업체수의 현황은 다음과 같다.

〈표 4-10〉 품목분석의 관광산업 기준 중분류 산업별, 규모에 따른 사업체수 현황

\begin{tabular}{|c|c|c|c|c|c|c|c|c|c|}
\hline \multirow{2}{*}{ 대분류 } & \multirow{2}{*}{ 중분류 } & \multicolumn{8}{|c|}{ 규모별 사업체 현황 } \\
\hline & & 전체 & 1 4인 & 5 9인 & 10 19인 & 20 49인 & 50 99인 & 100 299인 & 300 인 이상 \\
\hline \multirow{18}{*}{$\begin{array}{l}\text { 핵심 } \\
\text { 관광 } \\
\text { 산업 }\end{array}$} & \multirow{2}{*}{ 소계 } & 42,638 & 35,581 & 2,834 & 1,618 & 1,592 & 488 & 439 & 86 \\
\hline & & $100 \%$ & $83.4 \%$ & $6.6 \%$ & $3.8 \%$ & $3.7 \%$ & $1.1 \%$ & $1.0 \%$ & $0.2 \%$ \\
\hline & \multirow{2}{*}{$\begin{array}{l}\text { 관광 쇼핑업 } \\
\text { (도매업 제외) }\end{array}$} & 1,237 & 1,124 & 36 & 28 & 23 & 13 & 11 & 2 \\
\hline & & $100 \%$ & $90.9 \%$ & $2.9 \%$ & $2.3 \%$ & $1.9 \%$ & $1.1 \%$ & $0.9 \%$ & $0.2 \%$ \\
\hline & \multirow{2}{*}{ 관광 운수업 } & 1,420 & 249 & 189 & 331 & 525 & 98 & 18 & 10 \\
\hline & & $100 \%$ & $17.5 \%$ & $13.3 \%$ & $23.3 \%$ & $37.0 \%$ & $6.9 \%$ & $1.3 \%$ & $0.7 \%$ \\
\hline & \multirow{2}{*}{ 관광 숙박업 } & 24,107 & 22,498 & 579 & 398 & 355 & 131 & 109 & 37 \\
\hline & & $100 \%$ & $93.3 \%$ & $2.4 \%$ & $1.7 \%$ & $1.5 \%$ & $0.5 \%$ & $0.5 \%$ & $0.2 \%$ \\
\hline & \multirow{2}{*}{$\begin{array}{l}\text { 관광 음식점 및 } \\
\text { 주점업 }\end{array}$} & 1,468 & 1,064 & 196 & 81 & 101 & 23 & 2 & 1 \\
\hline & & $100 \%$ & $72.5 \%$ & $13.4 \%$ & $5.5 \%$ & $6.9 \%$ & $1.6 \%$ & $0.1 \%$ & $0.1 \%$ \\
\hline & \multirow{2}{*}{$\begin{array}{c}\text { 여행사 및 } \\
\text { 여행보조 서비스업 }\end{array}$} & 6,780 & 5,504 & 751 & 279 & 189 & 34 & 18 & 5 \\
\hline & & $100 \%$ & $81.2 \%$ & $11.1 \%$ & $4.1 \%$ & $2.8 \%$ & $0.5 \%$ & $0.3 \%$ & $0.1 \%$ \\
\hline & \multirow{2}{*}{ 국제회의업a } & 219 & 97 & 51 & 35 & 28 & 2 & 5 & 1 \\
\hline & & $100 \%$ & $44.3 \%$ & $23.3 \%$ & $16.0 \%$ & $12.8 \%$ & $0.9 \%$ & $2.3 \%$ & $0.5 \%$ \\
\hline & \multirow{2}{*}{\begin{tabular}{|c} 
문화, 오락 및 레저 \\
스포츠산업
\end{tabular}} & 7,391 & 5,045 & 1,032 & 466 & 371 & 187 & 267 & 23 \\
\hline & & $100 \%$ & $68.3 \%$ & $14.0 \%$ & $6.3 \%$ & $5.0 \%$ & $2.5 \%$ & $3.6 \%$ & $0.3 \%$ \\
\hline & \multirow{2}{*}{ 카지노업a } & 16 & - & - & - & - & - & 9 & 7 \\
\hline & & $100 \%$ & - & - & - & - & - & $56.3 \%$ & $43.8 \%$ \\
\hline
\end{tabular}




\begin{tabular}{|c|c|c|c|c|c|c|c|c|c|}
\hline \multirow{2}{*}{ 대분류 } & \multirow{2}{*}{ 중분류 } & \multicolumn{8}{|c|}{ 규모별 사업체 현황 } \\
\hline & & 전체 & 1 4인 & 5 9인 & 10 19인 & 20 49인 & 50 99인 & 100 299인 & 300 인 이상 \\
\hline \multirow{10}{*}{$\begin{array}{l}\text { 상호 } \\
\text { 의존 } \\
\text { 관광 } \\
\text { 산업 }\end{array}$} & \multirow{2}{*}{ 소계 } & 8,933 & 8,034 & 598 & 192 & 78 & 20 & 10 & 1 \\
\hline & & $100 \%$ & $89.9 \%$ & $6.7 \%$ & $2.1 \%$ & $0.9 \%$ & $0.2 \%$ & $0.1 \%$ & $0.0 \%$ \\
\hline & \multirow{2}{*}{ 관광 건설업 } & 192 & 61 & 50 & 45 & 22 & 11 & 3 & - \\
\hline & & $100 \%$ & $31.8 \%$ & $26.0 \%$ & $23.4 \%$ & $11.5 \%$ & $5.7 \%$ & $1.6 \%$ & - \\
\hline & \multirow{2}{*}{$\begin{array}{c}\text { 관광 및 레저용품 } \\
\text { 소매업 }\end{array}$} & 3,962 & 3,889 & 55 & 14 & 4 & - & - & - \\
\hline & & $100 \%$ & $98.2 \%$ & $1.4 \%$ & $0.4 \%$ & $0.1 \%$ & - & - & - \\
\hline & \multirow{2}{*}{$\begin{array}{l}\text { 관광 보험 및 } \\
\text { 금융서비스업 }\end{array}$} & 511 & 497 & 6 & 2 & 5 & 1 & - & - \\
\hline & & $100 \%$ & $97.3 \%$ & $1.2 \%$ & $0.4 \%$ & $1.0 \%$ & $0.2 \%$ & - & - \\
\hline & \multirow{2}{*}{ 레저장비업 } & 4,268 & 3,587 & 487 & 131 & 47 & 8 & 7 & 1 \\
\hline & & $100 \%$ & $84.0 \%$ & $11.4 \%$ & $3.1 \%$ & $1.1 \%$ & $0.2 \%$ & $0.2 \%$ & $0.0 \%$ \\
\hline \multirow{14}{*}{$\begin{array}{l}\text { 부분 } \\
\text { 적용 } \\
\text { 관광 } \\
\text { 산업 }\end{array}$} & \multirow{2}{*}{ 소계 } & 94,901 & 88,431 & 5,030 & 972 & 364 & 53 & 40 & 11 \\
\hline & & $100 \%$ & $93.2 \%$ & $5.3 \%$ & $1.0 \%$ & $0.4 \%$ & $0.1 \%$ & $0.0 \%$ & $0.0 \%$ \\
\hline & \multirow{2}{*}{$\begin{array}{l}\text { 관광 비인증 } \\
\text { 쇼핑업 }\end{array}$} & 5 & 4 & - & 1 & - & - & - & - \\
\hline & & $100 \%$ & $80.0 \%$ & - & $20.0 \%$ & - & - & - & - \\
\hline & \multirow{2}{*}{ 부분관광 운송업 } & 1,138 & 197 & 354 & 433 & 102 & 15 & 28 & 9 \\
\hline & & $100 \%$ & $17.3 \%$ & $31.1 \%$ & $38.0 \%$ & $9.0 \%$ & $1.3 \%$ & $2.5 \%$ & $0.8 \%$ \\
\hline & \multirow{2}{*}{ 부분관광 숙박업 } & 15,604 & 14,342 & 980 & 161 & 93 & 20 & 8 & - \\
\hline & & $100 \%$ & $91.9 \%$ & $6.3 \%$ & $1.0 \%$ & $0.6 \%$ & $0.1 \%$ & $0.1 \%$ & - \\
\hline & \multirow{2}{*}{$\begin{array}{c}\text { 부분관광 음식점 } \\
\text { 및 주점업 }\end{array}$} & 77,393 & 73,360 & 3,631 & 357 & 43 & 2 & - & - \\
\hline & & $100 \%$ & $94.8 \%$ & $4.7 \%$ & $0.5 \%$ & $0.1 \%$ & $0.0 \%$ & - & - \\
\hline & \multirow{2}{*}{ 부분관광 공연장업 } & 337 & 293 & 30 & 9 & 4 & 1 & - & - \\
\hline & & $100 \%$ & $86.9 \%$ & $8.9 \%$ & $2.7 \%$ & $1.2 \%$ & $0.3 \%$ & - & - \\
\hline & \multirow{2}{*}{$\begin{array}{c}\text { 부분관광 기타 } \\
\text { 서비스업 }\end{array}$} & 424 & 235 & 35 & 11 & 122 & 15 & 4 & 2 \\
\hline & & $100 \%$ & $55.4 \%$ & $8.3 \%$ & $2.6 \%$ & $28.8 \%$ & $3.5 \%$ & $0.9 \%$ & $0.5 \%$ \\
\hline \multirow{10}{*}{$\begin{array}{l}\text { 관광 } \\
\text { 지원 } \\
\text { 산업 }\end{array}$} & \multirow{2}{*}{ 소계 } & 580 & 355 & 63 & 58 & 58 & 20 & 15 & 11 \\
\hline & & $100 \%$ & $61.2 \%$ & $10.9 \%$ & $10.0 \%$ & $10.0 \%$ & $3.4 \%$ & $2.6 \%$ & $1.9 \%$ \\
\hline & \multirow{2}{*}{ 관광 연구 개발업 } & 26 & 14 & 3 & 1 & 1 & 3 & 4 & - \\
\hline & & $100 \%$ & $53.8 \%$ & $11.5 \%$ & $3.8 \%$ & $3.8 \%$ & $11.5 \%$ & $15.4 \%$ & - \\
\hline & \multirow{2}{*}{ 관광 공공기관 } & 193 & 32 & 27 & 48 & 53 & 15 & 8 & 10 \\
\hline & & $100 \%$ & $16.6 \%$ & $14.0 \%$ & $24.9 \%$ & $27.5 \%$ & $7.8 \%$ & $4.1 \%$ & $5.2 \%$ \\
\hline & \multirow{2}{*}{ 관광 교육서비스업 } & 155 & 135 & 10 & 4 & 2 & - & 3 & 1 \\
\hline & & $100 \%$ & $87.1 \%$ & $6.5 \%$ & $2.6 \%$ & $1.3 \%$ & - & $1.9 \%$ & $0.6 \%$ \\
\hline & \multirow{2}{*}{ 관광 단체 } & 206 & 174 & 23 & 5 & 2 & 2 & - & - \\
\hline & & $100 \%$ & $84.5 \%$ & $11.2 \%$ & $2.4 \%$ & $1.0 \%$ & $1.0 \%$ & - & - \\
\hline \multirow{2}{*}{\multicolumn{2}{|c|}{ 전체 }} & 147,052 & 132,401 & 8,525 & 2,840 & 2,092 & 581 & 504 & 109 \\
\hline & & $100 \%$ & $90.0 \%$ & $5.8 \%$ & $1.9 \%$ & $1.4 \%$ & $0.4 \%$ & $0.3 \%$ & $0.1 \%$ \\
\hline
\end{tabular}


중분류 산업별, 종사자수규모별 종사자수의 현황은 다음과 같다.

〈표 4-11〉 품목분석의 관광산업 기준 중분류 산업별, 규모에 따른 종사자수 현황

\begin{tabular}{|c|c|c|c|c|c|c|c|c|c|}
\hline \multirow{2}{*}{ 대분류 } & \multirow{2}{*}{ 중분류 } & \multicolumn{8}{|c|}{ 규모별 종사자수 현황 } \\
\hline & & 전체 & 1 4인 & 5 9인 & 10 19인 & 20 49인 & 50 99인 & 100 299인 & 300 인 이상 \\
\hline \multirow{18}{*}{$\begin{array}{l}\text { 핵심 } \\
\text { 관광 } \\
\text { 산업 }\end{array}$} & \multirow{2}{*}{ 소계 } & 334,367 & 67,072 & 18,036 & 21,976 & 48,390 & 33,733 & 67,502 & 77,658 \\
\hline & & $100 \%$ & $20.1 \%$ & $5.4 \%$ & $6.6 \%$ & $14.5 \%$ & $10.1 \%$ & $20.2 \%$ & $23.2 \%$ \\
\hline & \multirow{2}{*}{$\begin{array}{l}\text { 관광 쇼핑업 } \\
\text { (도매업 제외) }\end{array}$} & 6,453 & 1,627 & 238 & 389 & 660 & 972 & 1,695 & 872 \\
\hline & & $100 \%$ & $25.2 \%$ & $3.7 \%$ & $6.0 \%$ & $10.2 \%$ & $15.1 \%$ & $26.3 \%$ & $13.5 \%$ \\
\hline & \multirow{2}{*}{ 관광 운수업 } & 59,330 & 557 & 1,299 & 4,679 & 16,119 & 6,097 & 2,281 & 28,298 \\
\hline & & $100 \%$ & $0.9 \%$ & $2.2 \%$ & $7.9 \%$ & $27.2 \%$ & $10.3 \%$ & $3.8 \%$ & $47.7 \%$ \\
\hline & \multirow{2}{*}{ 관광 숙박업 } & 109,991 & 41,158 & 3,547 & 5,382 & 10,937 & 8,963 & 17,890 & 22,114 \\
\hline & & $100 \%$ & $37.4 \%$ & $3.2 \%$ & $4.9 \%$ & $9.9 \%$ & $8.1 \%$ & $16.3 \%$ & $20.1 \%$ \\
\hline & \multirow{2}{*}{$\begin{array}{l}\text { 관광 음식점 및 } \\
\text { 주점업 }\end{array}$} & 9,962 & 2,243 & 1,226 & 1,105 & 2,975 & 1,492 & 251 & 670 \\
\hline & & $100 \%$ & $22.5 \%$ & $12.3 \%$ & $11.1 \%$ & $29.9 \%$ & $15.0 \%$ & $2.5 \%$ & $6.7 \%$ \\
\hline & \multirow{2}{*}{$\begin{array}{l}\text { 여행사 및 여행 } \\
\text { 보조 서비스업 }\end{array}$} & 33,066 & 11,218 & 4,747 & 3,708 & 5,598 & 2,331 & 3,011 & 2,453 \\
\hline & & $100 \%$ & $33.9 \%$ & $14.4 \%$ & $11.2 \%$ & $16.9 \%$ & $7.0 \%$ & $9.1 \%$ & $7.4 \%$ \\
\hline & \multirow{2}{*}{ 국제회의업a } & 3,559 & 206 & 323 & 448 & 882 & 131 & 809 & 760 \\
\hline & & $100 \%$ & $5.8 \%$ & $9.1 \%$ & $12.6 \%$ & $24.8 \%$ & $3.7 \%$ & $22.7 \%$ & $21.4 \%$ \\
\hline & \multirow{2}{*}{$\begin{array}{c}\text { 문화, 오락 및 } \\
\text { 레저 스포츠산업 }\end{array}$} & 103,278 & 10,063 & 6,656 & 6,265 & 11,219 & 13,747 & 40,094 & 15,234 \\
\hline & & $100 \%$ & $9.7 \%$ & $6.4 \%$ & $6.1 \%$ & $10.9 \%$ & $13.3 \%$ & $38.8 \%$ & $14.8 \%$ \\
\hline & \multirow{2}{*}{ 카지노업a } & 8,728 & - & - & - & - & - & 1,471 & 7,257 \\
\hline & & $100 \%$ & - & - & - & - & - & $16.9 \%$ & $83.1 \%$ \\
\hline \multirow{10}{*}{$\begin{array}{l}\text { 상호 } \\
\text { 의존 } \\
\text { 관광 } \\
\text { 산업 }\end{array}$} & \multirow{2}{*}{ 소계 } & 25,434 & 13,585 & 3,845 & 2,474 & 2,131 & 1,325 & 1,774 & 300 \\
\hline & & $100 \%$ & $53.4 \%$ & $15.1 \%$ & $9.7 \%$ & $8.4 \%$ & $5.2 \%$ & $7.0 \%$ & $1.2 \%$ \\
\hline & \multirow{2}{*}{ 관광 건설업 } & 2,684 & 139 & 352 & 597 & 575 & 716 & 305 & - \\
\hline & & $100 \%$ & $5.2 \%$ & $13.1 \%$ & $22.2 \%$ & $21.4 \%$ & $26.7 \%$ & $11.4 \%$ & - \\
\hline & \multirow{2}{*}{$\begin{array}{c}\text { 관광 및 } \\
\text { 레저용품 소매업 }\end{array}$} & 6,374 & 5,761 & 321 & 188 & 104 & - & - & - \\
\hline & & $100 \%$ & $90.4 \%$ & $5.0 \%$ & $2.9 \%$ & $1.6 \%$ & - & - & - \\
\hline & \multirow{2}{*}{$\begin{array}{l}\text { 관광 보험 및 } \\
\text { 금융서비스업 }\end{array}$} & 1,029 & 717 & 36 & 29 & 151 & 96 & - & - \\
\hline & & $100 \%$ & $69.7 \%$ & $3.5 \%$ & $2.8 \%$ & $14.7 \%$ & $9.3 \%$ & - & - \\
\hline & \multirow{2}{*}{ 레저장비업 } & 15,347 & 6,968 & 3,136 & 1,660 & 1,301 & 513 & 1,469 & 300 \\
\hline & & $100 \%$ & $45.4 \%$ & $20.4 \%$ & $10.8 \%$ & $8.5 \%$ & $3.3 \%$ & $9.6 \%$ & $2.0 \%$ \\
\hline
\end{tabular}




\begin{tabular}{|c|c|c|c|c|c|c|c|c|c|}
\hline \multirow{2}{*}{ 대분류 } & \multirow{2}{*}{ 중분류 } & \multicolumn{8}{|c|}{ 규모별 종사자수 현황 } \\
\hline & & 전체 & 1 4인 & $5 \sim 9$ 인 & 10 19인 & 20 49인 & 50 99인 & 100 299인 & 300인 이싱 \\
\hline \multirow{14}{*}{$\begin{array}{l}\text { 부분 } \\
\text { 적용 } \\
\text { 관광 } \\
\text { 산업 }\end{array}$} & \multirow{2}{*}{ 소계 } & 231,441 & 161,636 & 30,453 & 12,566 & 10,597 & 3,744 & 6,309 & 6,136 \\
\hline & & $100 \%$ & $69.8 \%$ & $13.2 \%$ & $5.4 \%$ & $4.6 \%$ & $1.6 \%$ & $2.7 \%$ & $2.7 \%$ \\
\hline & \multirow{2}{*}{$\begin{array}{l}\text { 관광 비인증 } \\
\text { 쇼핑업 }\end{array}$} & 22 & 8 & - & 14 & - & - & - & - \\
\hline & & $100 \%$ & $36.4 \%$ & - & $63.6 \%$ & - & - & - & - \\
\hline & \multirow{2}{*}{ 부분관광 운송업 } & 22,866 & 488 & 2,498 & 5,747 & 2,726 & 1,153 & 4,734 & 5,520 \\
\hline & & $100 \%$ & $2.1 \%$ & $10.9 \%$ & $25.1 \%$ & $11.9 \%$ & $5.0 \%$ & $20.7 \%$ & $24.1 \%$ \\
\hline & \multirow{2}{*}{ 부분관광 숙박업 } & 41,285 & 27,809 & 5,943 & 2,114 & 2,961 & 1,339 & 1,119 & - \\
\hline & & $100 \%$ & $67.4 \%$ & $14.4 \%$ & $5.1 \%$ & $7.2 \%$ & $3.2 \%$ & $2.7 \%$ & - \\
\hline & \multirow{2}{*}{$\begin{array}{c}\text { 부분관광 음식점 } \\
\text { 및 주점업 }\end{array}$} & 159,816 & 132,418 & 21,624 & 4,423 & 1,187 & 164 & - & - \\
\hline & & $100 \%$ & $82.9 \%$ & $13.5 \%$ & $2.8 \%$ & $0.7 \%$ & $0.1 \%$ & - & - \\
\hline & \multirow{2}{*}{$\begin{array}{l}\text { 부분관광 } \\
\text { 공연장업 }\end{array}$} & 1,030 & 553 & 166 & 108 & 118 & 85 & - & - \\
\hline & & $100 \%$ & $53.7 \%$ & $16.1 \%$ & $10.5 \%$ & $11.5 \%$ & $8.3 \%$ & - & - \\
\hline & \multirow{2}{*}{$\begin{array}{c}\text { 부분관광 기타 } \\
\text { 서비스업 }\end{array}$} & 6,422 & 360 & 222 & 160 & 3,605 & 1,003 & 456 & 616 \\
\hline & & $100 \%$ & $5.6 \%$ & $3.5 \%$ & $2.5 \%$ & $56.1 \%$ & $15.6 \%$ & $7.1 \%$ & $9.6 \%$ \\
\hline \multirow{10}{*}{$\begin{array}{l}\text { 관광 } \\
\text { 지원 } \\
\text { 산업 }\end{array}$} & \multirow{2}{*}{ 소계 } & 16,378 & 671 & 396 & 764 & 1,825 & 1,446 & 2,442 & 8,834 \\
\hline & & $100 \%$ & $4.1 \%$ & $2.4 \%$ & $4.7 \%$ & $11.1 \%$ & $8.8 \%$ & $14.9 \%$ & $53.9 \%$ \\
\hline & \multirow{2}{*}{$\begin{array}{l}\text { 관광 연구 } \\
\text { 개발업 }\end{array}$} & 847 & 20 & 16 & 17 & 28 & 199 & 567 & - \\
\hline & & $100 \%$ & $2.4 \%$ & $1.9 \%$ & $2.0 \%$ & $3.3 \%$ & $23.5 \%$ & $66.9 \%$ & - \\
\hline & \multirow{2}{*}{ 관광 공공기관 } & 13,546 & 84 & 177 & 637 & 1,662 & 1,133 & 1,351 & 8,502 \\
\hline & & $100 \%$ & $0.6 \%$ & $1.3 \%$ & $4.7 \%$ & $12.3 \%$ & $8.4 \%$ & $10.0 \%$ & $62.8 \%$ \\
\hline & \multirow{2}{*}{$\begin{array}{c}\text { 관광 } \\
\text { 교육서비스업 }\end{array}$} & 1,244 & 218 & 62 & 54 & 54 & - & 524 & 332 \\
\hline & & $100 \%$ & $17.5 \%$ & $5.0 \%$ & $4.3 \%$ & $4.3 \%$ & - & $42.1 \%$ & $26.7 \%$ \\
\hline & \multirow{2}{*}{ 관광 단체 } & 741 & 349 & 141 & 56 & 81 & 114 & - & - \\
\hline & & $100 \%$ & $47.1 \%$ & $19.0 \%$ & $7.6 \%$ & $10.9 \%$ & $15.4 \%$ & - & - \\
\hline & \multirow{2}{*}{ 전체 } & 607,620 & 242,964 & 52,730 & 37,780 & 62,943 & 40,248 & 78,027 & 92,928 \\
\hline & & $100.0 \%$ & $40.0 \%$ & $8.7 \%$ & $6.2 \%$ & $10.4 \%$ & $6.6 \%$ & $12.8 \%$ & $15.3 \%$ \\
\hline
\end{tabular}

100 인 이상의 사업체수 누적비중은 $0.4 \%$ (613개/ 147,052 개)를 차지하고 있고 종사자수 누적비중은 28.1\%(170,955명/607,620명)에 해당하며 사업체당 평균 종 사자수는 278.9명(전체 평균은 4.13명)에 해당한다. 
[그림 4-5] 관광산업(품목분석) 규모별 사업체수 누적과 종사자수 누적과의 관계

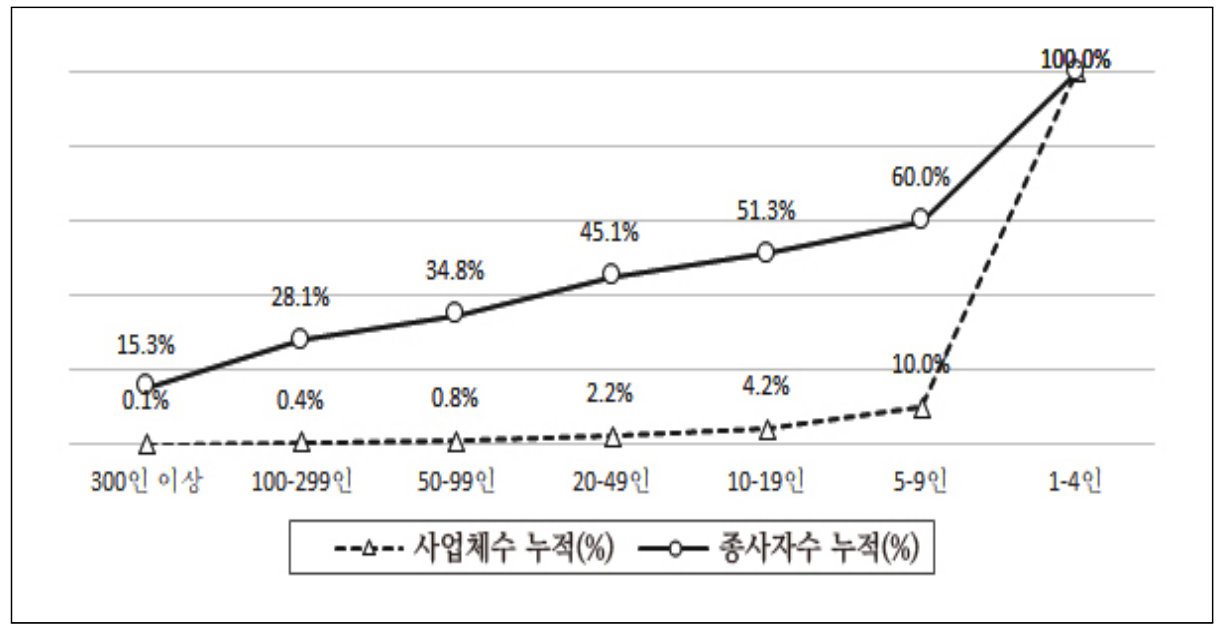

산업 전체에 대한 종사자수의 평균은 4.1명, 변동계수12)는 평균의 11.5 배로 매 우 크다. 종사자수 규모를 100 인 기준으로 변동계수를 산출하면 100 인 미만은 2.0, 100 인 이상은 2.4로 규모를 고려하지 않은 경우 대비 변동은 매우 작아지게 된다.

〈표 4-12〉 품목분석의 관광산업 기준의 평균 종사자수와 변동계수 현황

\begin{tabular}{|c|c|c|c|c|c|c|c|}
\hline \multirow[b]{2}{*}{ 대분류 } & \multirow[b]{2}{*}{ 중분류 } & \multicolumn{2}{|c|}{ 전체 } & \multicolumn{2}{|c|}{ 1 99인 } & \multicolumn{2}{|c|}{100 인 이상 } \\
\hline & & 평균 & $\begin{array}{l}\text { 변동 } \\
\text { 계수 }\end{array}$ & 평균 & $\begin{array}{l}\text { 변동 } \\
\text { 계수 }\end{array}$ & 평균 & $\begin{array}{l}\text { 변동 } \\
\text { 계수 }\end{array}$ \\
\hline \multirow{9}{*}{$\begin{array}{l}\text { 핵심 } \\
\text { 관광 } \\
\text { 산업 }\end{array}$} & 소계 & 7.8 & 10.9 & 4.5 & 2.1 & 276.5 & 2.6 \\
\hline & 관광 쇼핑업(도매업 제외) & 5.2 & 4.7 & 3.2 & 2.8 & 197.5 & 0.6 \\
\hline & 관광 운수업 & 41.8 & 9.9 & 20.7 & 0.8 & 1092.1 & 2.5 \\
\hline & 관광 숙박업 & 4.6 & 7.3 & 2.9 & 2.2 & 274.0 & 1.2 \\
\hline & 관광 음식점 및 주점업 & 6.8 & 3.1 & 6.2 & 1.7 & 307.0 & 1.0 \\
\hline & 여행사 및 여행보조 서비스업 & 4.9 & 3.7 & 4.1 & 1.7 & 237.6 & 0.7 \\
\hline & 국제회의업a & 16.3 & 3.5 & 9.3 & 1.2 & 261.5 & 1.0 \\
\hline & 문화, 오락 및 레저 스포츠산업 & 14.0 & 4.2 & 6.8 & 2.0 & 190.8 & 1.2 \\
\hline & 카지노업a & 545.5 & 1.4 & - & 0.0 & 545.5 & 1.4 \\
\hline
\end{tabular}

12) 변동계수(Coefficient of Variation)는 표준편차를 평균으로 나눈 것으로 평균 대비 상대적인 변동을 나타 낸다. 변동계수가 0.5 이면 표준편차가 평균의 $50 \%$ 수준임을 의미한다. 층화의 필요성 검토 목적으로 모 집단 자료의 동질성을 파악하기 위한 척도로 활용된다. 


\begin{tabular}{|c|c|c|c|c|c|c|c|}
\hline \multirow[b]{2}{*}{ 대분류 } & \multirow[b]{2}{*}{ 중분류 } & \multicolumn{2}{|c|}{ 전체 } & \multicolumn{2}{|c|}{ 1 99인 } & \multicolumn{2}{|c|}{100 인 이상 } \\
\hline & & 평균 & $\begin{array}{l}\text { 변동 } \\
\text { 계수 }\end{array}$ & 평균 & $\begin{array}{l}\text { 변동 } \\
\text { 계수 }\end{array}$ & 평균 & $\begin{array}{l}\text { 변동 } \\
\text { 계수 }\end{array}$ \\
\hline \multirow{5}{*}{$\begin{array}{l}\text { 상호 } \\
\text { 의존 } \\
\text { 관광 } \\
\text { 산업 }\end{array}$} & 소계 & 2.9 & 2.9 & 2.6 & 1.7 & 188.6 & 0.4 \\
\hline & 관광 건설업 & 14.0 & 1.4 & 12.6 & 1.2 & 101.7 & 0.0 \\
\hline & 관광 및 레저용품 소매업 & 1.6 & 0.9 & 1.6 & 0.9 & - & - \\
\hline & 관광 보험 및 금융서비스업 & 2.0 & 2.6 & 2.0 & 2.6 & - & - \\
\hline & 레저장비업 & 3.6 & 3.0 & 3.2 & 1.4 & 221.1 & 0.3 \\
\hline \multirow{7}{*}{$\begin{array}{l}\text { 부분 } \\
\text { 적용 } \\
\text { 관광 } \\
\text { 산업 }\end{array}$} & 소계 & 2.4 & 3.3 & 2.3 & 1.3 & 244.0 & 0.9 \\
\hline & 관광 비인증 쇼핑업 & 4.4 & 1.3 & 4.4 & 1.3 & - & - \\
\hline & 부분관광 운송업 & 20.1 & 3.2 & 11.5 & 0.9 & 277.1 & 0.9 \\
\hline & 부분관광 숙박업 & 2.7 & 1.9 & 2.6 & 1.5 & 139.9 & 0.2 \\
\hline & 부분관광 음식점 및 주점업 & 2.1 & 0.8 & 2.1 & 0.8 & - & - \\
\hline & 부분관광 공연장업 & 3.1 & 1.9 & 3.1 & 1.9 & - & - \\
\hline & 부분관광 기타 서비스업 & 15.2 & 1.9 & 12.8 & 1.3 & 178.7 & 0.6 \\
\hline \multirow{5}{*}{$\begin{array}{l}\text { 관광 } \\
\text { 지원 } \\
\text { 산업 }\end{array}$} & 소계 & 28.2 & 4.9 & 9.2 & 1.7 & 433.7 & 1.2 \\
\hline & 관광 연구 개발업 & 32.6 & 1.7 & 12.7 & 1.8 & 141.8 & 0.3 \\
\hline & 관광 공공기관 & 70.2 & 3.3 & 21.1 & 1.0 & 547.4 & 1.0 \\
\hline & 관광 교육서비스업 & 8.0 & 4.6 & 2.6 & 1.5 & 214.0 & 0.5 \\
\hline & 관광 단체 & 3.6 & 1.9 & 3.6 & 1.9 & - & - \\
\hline 전체 & & 4.1 & 11.5 & 3.0 & 2.0 & 278.9 & 2.4 \\
\hline
\end{tabular}

\section{라. 4단계: 관광산업특수분류 전체 사업체}

관광산업특수분류로 구분되는 모든 사업체는 총 722,853 개이며 총 종사자수는 2,930,345명이다. 
〈표 4-13〉 관광산업특수분류 전체의 모집단 현황

\begin{tabular}{|c|c|c|c|c|c|}
\hline \multirow[b]{2}{*}{ 대분류 } & \multirow[b]{2}{*}{ 중분류 } & \multicolumn{2}{|c|}{ 사업체 현황 } & \multicolumn{2}{|c|}{ 종사자수 현황 } \\
\hline & & $\begin{array}{c}\text { 사업체수 } \\
\text { (개) }\end{array}$ & 비중 & $\begin{array}{c}\text { 종사자수 } \\
\text { (명) }\end{array}$ & 비중 \\
\hline \multirow{9}{*}{$\begin{array}{l}\text { 핵심 } \\
\text { 관광 } \\
\text { 산업 }\end{array}$} & 소계 & 77,705 & $10.75 \%$ & 530,915 & $18.12 \%$ \\
\hline & 관광 쇼핑업(도매업 제외) & 1,483 & $0.21 \%$ & 7,118 & $0.24 \%$ \\
\hline & 관광 운수업 & 1,563 & $0.22 \%$ & 65,176 & $2.22 \%$ \\
\hline & 관광 숙박업 & 31,609 & $4.37 \%$ & 134,639 & $4.59 \%$ \\
\hline & 관광 음식점 및 주점업 & 24,675 & $3.41 \%$ & 152,633 & $5.21 \%$ \\
\hline & 여행사 및 여행보조 서비스업 & 10,099 & $1.40 \%$ & 49,870 & $1.70 \%$ \\
\hline & 국제회의업a & 339 & $0.05 \%$ & 4,713 & $0.16 \%$ \\
\hline & 문화, 오락 및 레저 스포츠산업 & 7,921 & $1.10 \%$ & 108,038 & $3.69 \%$ \\
\hline & 카지노업a & 16 & $0.00 \%$ & 8,728 & $0.30 \%$ \\
\hline \multirow{5}{*}{$\begin{array}{l}\text { 상호 } \\
\text { 의존 } \\
\text { 관광 } \\
\text { 산업 }\end{array}$} & 소계 & 34,928 & $4.83 \%$ & 166,745 & $5.69 \%$ \\
\hline & 관광 건설업 & 2,557 & $0.35 \%$ & 13,299 & $0.45 \%$ \\
\hline & 관광 및 레저용품 소매업 & 24,630 & $3.41 \%$ & 53,356 & $1.82 \%$ \\
\hline & 관광 보험 및 금융서비스업 & 3,274 & $0.45 \%$ & 84,178 & $2.87 \%$ \\
\hline & 레저장비업 & 4,467 & $0.62 \%$ & 15,912 & $0.54 \%$ \\
\hline \multirow{7}{*}{$\begin{array}{l}\text { 부분 } \\
\text { 적용 } \\
\text { 관광 } \\
\text { 산업 }\end{array}$} & 소계 & 578,678 & $80.05 \%$ & $1,814,121$ & $61.91 \%$ \\
\hline & 관광 비인증 쇼핑업 & 116,409 & $16.10 \%$ & 478,771 & $16.34 \%$ \\
\hline & 부분관광 운송업 & 5,489 & $0.76 \%$ & 46,610 & $1.59 \%$ \\
\hline & 부분관광 숙박업 & 18,246 & $2.52 \%$ & 47,695 & $1.63 \%$ \\
\hline & 부분관광 음식점 및 주점업 & 435,911 & $60.30 \%$ & $1,214,221$ & $41.44 \%$ \\
\hline & 부분관광 공연장업 & 449 & $0.06 \%$ & 6,136 & $0.21 \%$ \\
\hline & 부분관광 기타 서비스업 & 2,174 & $0.30 \%$ & 20,688 & $0.71 \%$ \\
\hline \multirow{5}{*}{$\begin{array}{l}\text { 관광 } \\
\text { 지원 } \\
\text { 산업 }\end{array}$} & 소계 & 31,542 & $4.36 \%$ & 418,564 & $14.28 \%$ \\
\hline & 관광 연구 개발업 & 203 & $0.03 \%$ & 3,774 & $0.13 \%$ \\
\hline & 관광 공공기관 & 3,477 & $0.48 \%$ & 146,270 & $4.99 \%$ \\
\hline & 관광 교육서비스업 & 27,656 & $3.83 \%$ & 267,779 & $9.14 \%$ \\
\hline & 관광 단체 & 206 & $0.03 \%$ & 741 & $0.03 \%$ \\
\hline \multicolumn{2}{|r|}{ 전체 } & 722,853 & $100 \%$ & $2,930,345$ & $100 \%$ \\
\hline
\end{tabular}

핵심 관광산업과 부분적용 관광산업은 656,383개로 $90.80 \%$ 를 차지하고 있고 종사자수는 2,345,036명으로 80.03\%를 차지하고 있다. 상호의존 관광산업과 관광 지원산업의 경우 사업체는 각각 34,928 개, 31,542 개이고 종사자수는 166,745 명, 418,564 명을 나타내고 있다. 중분류 산업별, 종사자수규모별 사업체수의 현황은 다음과 같다. 
〈표 4-14〉 관광산업특수분류 전체의 중분류 산업별, 규모에 따른 사업체수 현황

\begin{tabular}{|c|c|c|c|c|c|c|c|c|c|}
\hline \multirow[b]{2}{*}{ 대분류 } & \multirow[b]{2}{*}{ 중분류 } & \multicolumn{8}{|c|}{ 규모별 사업체 현황 } \\
\hline & & 전체 & 1 4인 & $5 \sim 9$ 인 & 10 19인 & 20 49인 & 50 99인 & $\begin{array}{c}100 \sim 299 \\
\text { 인 }\end{array}$ & $\begin{array}{c}300 \text { 인 } \\
\text { 이상 }\end{array}$ \\
\hline \multirow{18}{*}{$\begin{array}{l}\text { 핵심 } \\
\text { 관광 } \\
\text { 산업 }\end{array}$} & \multirow{2}{*}{ 소계 } & 77,705 & 62,222 & 7,578 & 3,476 & 3,012 & 812 & 505 & 100 \\
\hline & & $100 \%$ & $80.1 \%$ & $9.8 \%$ & $4.5 \%$ & $3.9 \%$ & $1.0 \%$ & $0.6 \%$ & $0.1 \%$ \\
\hline & \multirow{2}{*}{$\begin{array}{l}\text { 관광 쇼핑업 } \\
\text { (도매업 제외) }\end{array}$} & 1,483 & 1,354 & 43 & 31 & 28 & 14 & 11 & 2 \\
\hline & & $100 \%$ & $91.3 \%$ & $2.9 \%$ & $2.1 \%$ & $1.9 \%$ & $0.9 \%$ & $0.7 \%$ & $0.1 \%$ \\
\hline & \multirow{2}{*}{ 관광 운수업 } & 1,563 & 264 & 217 & 364 & 571 & 114 & 21 & 12 \\
\hline & & $100 \%$ & $16.9 \%$ & $13.9 \%$ & $23.3 \%$ & $36.5 \%$ & $7.3 \%$ & $1.3 \%$ & $0.8 \%$ \\
\hline & \multirow{2}{*}{ 관광 숙박업 } & 31,609 & 28,539 & 1,831 & 595 & 366 & 132 & 109 & 37 \\
\hline & & $100 \%$ & $90.3 \%$ & $5.8 \%$ & $1.9 \%$ & $1.2 \%$ & $0.4 \%$ & $0.3 \%$ & $0.1 \%$ \\
\hline & \multirow{2}{*}{$\begin{array}{l}\text { 관광 음식점 및 } \\
\text { 주점법 } \\
\end{array}$} & 24,675 & 18,263 & 3,182 & 1,531 & 1,353 & 288 & 51 & 7 \\
\hline & & $100 \%$ & $74.0 \%$ & $12.9 \%$ & $6.2 \%$ & $5.5 \%$ & $1.2 \%$ & $0.2 \%$ & $0.0 \%$ \\
\hline & \multirow{2}{*}{$\begin{array}{c}\text { 여행사 및 여행보조 } \\
\text { 서비스업 }\end{array}$} & 10,099 & 8,192 & 1,133 & 412 & 271 & 55 & 28 & 8 \\
\hline & & $100 \%$ & $81.1 \%$ & $11.2 \%$ & $4.1 \%$ & $2.7 \%$ & $0.5 \%$ & $0.3 \%$ & $0.1 \%$ \\
\hline & \multirow{2}{*}{ 국제회의업a } & 339 & 172 & 77 & 47 & 31 & 5 & 5 & 2 \\
\hline & & $100 \%$ & $50.7 \%$ & $22.7 \%$ & $13.9 \%$ & $9.1 \%$ & $1.5 \%$ & $1.5 \%$ & $0.6 \%$ \\
\hline & \multirow{2}{*}{$\begin{array}{l}\text { 문화, 오락 및 } \\
\text { 레저 스포츠산업 }\end{array}$} & 7,921 & 5,438 & 1,095 & 496 & 392 & 204 & 271 & 25 \\
\hline & & $100 \%$ & $68.7 \%$ & $13.8 \%$ & $6.3 \%$ & $4.9 \%$ & $2.6 \%$ & $3.4 \%$ & $0.3 \%$ \\
\hline & \multirow{2}{*}{ 카지노업a } & 16 & - & - & - & - & - & 9 & 7 \\
\hline & & $100 \%$ & - & - & - & - & - & $56.3 \%$ & $43.8 \%$ \\
\hline \multirow{10}{*}{$\begin{array}{l}\text { 상호 } \\
\text { 의존 } \\
\text { 관광 } \\
\text { 산업 }\end{array}$} & \multirow{2}{*}{ 소계 } & 34,928 & 29,686 & 2,887 & 800 & 1,103 & 359 & 78 & 15 \\
\hline & & $100 \%$ & $85.0 \%$ & $8.3 \%$ & $2.3 \%$ & $3.2 \%$ & $1.0 \%$ & $0.2 \%$ & $0.0 \%$ \\
\hline & \multirow{2}{*}{ 관광 건설업 } & 2,557 & 1,435 & 924 & 159 & 22 & 12 & 5 & - \\
\hline & & $100 \%$ & $56.1 \%$ & $36.1 \%$ & $6.2 \%$ & $0.9 \%$ & $0.5 \%$ & $0.2 \%$ & - \\
\hline & \multirow{2}{*}{$\begin{array}{c}\text { 관광 및 레저용품 } \\
\text { 소매업 }\end{array}$} & 24,630 & 23,522 & 953 & 100 & 47 & 6 & 2 & - \\
\hline & & $100 \%$ & $95.5 \%$ & $3.9 \%$ & $0.4 \%$ & $0.2 \%$ & $0.0 \%$ & $0.0 \%$ & - \\
\hline & \multirow{2}{*}{$\begin{array}{l}\text { 관광 보험 및 } \\
\text { 금융서비스업 }\end{array}$} & 3,274 & 961 & 513 & 405 & 984 & 333 & 64 & 14 \\
\hline & & $100 \%$ & $29.4 \%$ & $15.7 \%$ & $12.4 \%$ & $30.1 \%$ & $10.2 \%$ & $2.0 \%$ & $0.4 \%$ \\
\hline & \multirow{2}{*}{ 레저장비업 } & 4,467 & 3,768 & 497 & 136 & 50 & 8 & 7 & 1 \\
\hline & & $100 \%$ & $84.4 \%$ & $11.1 \%$ & $3.0 \%$ & $1.1 \%$ & $0.2 \%$ & $0.2 \%$ & $0.0 \%$ \\
\hline \multirow{8}{*}{$\begin{array}{l}\text { 부분 } \\
\text { 적용 } \\
\text { 관광 } \\
\text { 산업 }\end{array}$} & \multirow{2}{*}{ 소계 } & 578,678 & 495,084 & 69,638 & 10,640 & 2,345 & 393 & 525 & 53 \\
\hline & & $100 \%$ & $85.6 \%$ & $12.0 \%$ & $1.8 \%$ & $0.4 \%$ & $0.1 \%$ & $0.1 \%$ & $0.0 \%$ \\
\hline & \multirow{2}{*}{ 관광 비인증 쇼핑업 } & 116,409 & 92,871 & 17,980 & 3,420 & 1,450 & 245 & 412 & 31 \\
\hline & & $100 \%$ & $79.8 \%$ & $15.4 \%$ & $2.9 \%$ & $1.2 \%$ & $0.2 \%$ & $0.4 \%$ & $0.0 \%$ \\
\hline & \multirow{2}{*}{ 부분관광 운송업 } & 5,489 & 4,273 & 406 & 475 & 169 & 71 & 79 & 16 \\
\hline & & $100 \%$ & $77.8 \%$ & $7.4 \%$ & $8.7 \%$ & $3.1 \%$ & $1.3 \%$ & $1.4 \%$ & $0.3 \%$ \\
\hline & \multirow{2}{*}{ 부분관광 숙박업 } & 18,246 & 16,771 & 1,165 & 184 & 96 & 21 & 9 & - \\
\hline & & $100 \%$ & $91.9 \%$ & $6.4 \%$ & $1.0 \%$ & $0.5 \%$ & $0.1 \%$ & $0.0 \%$ & - \\
\hline
\end{tabular}




\begin{tabular}{|c|c|c|c|c|c|c|c|c|c|}
\hline \multirow[b]{2}{*}{ 대분류 } & \multirow[b]{2}{*}{ 중분류 } & \multicolumn{8}{|c|}{ 규모별 사업체 현황 } \\
\hline & & 전체 & 1 4인 & $5 \sim 9$ 인 & 10 19인 & 20 49인 & 50 99인 & $\begin{array}{c}100 \sim 299 \\
\text { 인 }\end{array}$ & $\begin{array}{c}300 \text { 인 } \\
\text { 이상 }\end{array}$ \\
\hline & 부분관광 음식점 및 & 435,911 & 380,631 & 48,662 & 6,124 & 460 & 27 & 5 & 2 \\
\hline & 주점업 & $100 \%$ & $87.3 \%$ & $11.2 \%$ & $1.4 \%$ & $0.1 \%$ & $0.0 \%$ & $0.0 \%$ & $0.0 \%$ \\
\hline & 비브과과 고여자어 & 449 & 303 & 57 & 32 & 33 & 7 & 15 & 2 \\
\hline & ㅜㅜ눈난 & $100 \%$ & $67.5 \%$ & $12.7 \%$ & $7.1 \%$ & $7.3 \%$ & $1.6 \%$ & $3.3 \%$ & $0.4 \%$ \\
\hline & 부분관광 기타 & 2,174 & 235 & 1,368 & 405 & 137 & 22 & 5 & 2 \\
\hline & 서비스업 & $100 \%$ & $10.8 \%$ & $62.9 \%$ & $18.6 \%$ & $6.3 \%$ & $1.0 \%$ & $0.2 \%$ & $0.1 \%$ \\
\hline \multirow{10}{*}{$\begin{array}{l}\text { 관광 } \\
\text { 지원 } \\
\text { 산업 }\end{array}$} & \multirow{2}{*}{ 소계 } & 31,542 & 26,270 & 2,532 & 882 & 964 & 338 & 261 & 295 \\
\hline & & $100 \%$ & $83.3 \%$ & $8.0 \%$ & $2.8 \%$ & $3.1 \%$ & $1.1 \%$ & $0.8 \%$ & $0.9 \%$ \\
\hline & \multirow{2}{*}{ 관광 연구 개발업 } & 203 & 125 & 34 & 15 & 14 & 6 & 6 & 3 \\
\hline & & $100 \%$ & $61.6 \%$ & $16.7 \%$ & $7.4 \%$ & $6.9 \%$ & $3.0 \%$ & $3.0 \%$ & $1.5 \%$ \\
\hline & \multirow{2}{*}{ 관광 공공기관 } & 3,477 & 842 & 670 & 560 & 862 & 264 & 169 & 110 \\
\hline & & $100 \%$ & $24.2 \%$ & $19.3 \%$ & $16.1 \%$ & $24.8 \%$ & $7.6 \%$ & $4.9 \%$ & $3.2 \%$ \\
\hline & \multirow{2}{*}{ 관광 교육서비스업 } & 27,656 & 25,129 & 1,805 & 302 & 86 & 66 & 86 & 182 \\
\hline & & $100 \%$ & $90.9 \%$ & $6.5 \%$ & $1.1 \%$ & $0.3 \%$ & $0.2 \%$ & $0.3 \%$ & $0.7 \%$ \\
\hline & \multirow{2}{*}{ 관광 단체 } & 206 & 174 & 23 & 5 & 2 & 2 & - & - \\
\hline & & $100 \%$ & $84.5 \%$ & $11.2 \%$ & $2.4 \%$ & $1.0 \%$ & $1.0 \%$ & - & - \\
\hline \multirow{2}{*}{\multicolumn{2}{|c|}{ 전체 }} & 722,853 & 613,262 & 82,635 & 15,798 & 7,424 & 1,902 & 1,369 & 463 \\
\hline & & $100 \%$ & $84.8 \%$ & $11.4 \%$ & $2.2 \%$ & $1.0 \%$ & $0.3 \%$ & $0.2 \%$ & $0.1 \%$ \\
\hline
\end{tabular}

중분류 산업별, 종사자수규모별 종사자수의 현황은 다음과 같다.

〈표 4-15〉 관광산업특수분류 전체의 중분류 산업별, 규모에 따른 종사자수 현황

\begin{tabular}{|c|c|c|c|c|c|c|c|c|c|}
\hline \multirow[b]{2}{*}{ 대분류 } & \multirow[b]{2}{*}{ 중분류 } & \multicolumn{8}{|c|}{ 규모별 종사자수 현황 } \\
\hline & & 전체 & 1 4인 & $5 \sim 9$ 인 & 10 19인 & $20 \sim 49$ 인 & 50 99인 & \begin{tabular}{|}
$100 \sim 299$ \\
인
\end{tabular} & $\begin{array}{l}\text { 300인 } \\
\text { 이상 }\end{array}$ \\
\hline \multirow{12}{*}{$\begin{array}{l}\text { 핵심 } \\
\text { 관광 } \\
\text { 산업 }\end{array}$} & \multirow{2}{*}{ 소계 } & 530,915 & 127,204 & 47,122 & 48,615 & 90,077 & 54,784 & 77,899 & 85,214 \\
\hline & & $100 \%$ & $24.0 \%$ & $8.9 \%$ & $9.2 \%$ & $17.0 \%$ & $10.3 \%$ & $14.7 \%$ & $16.1 \%$ \\
\hline & \multirow{2}{*}{$\begin{array}{l}\text { 관광 쇼핑업 } \\
\text { (도매업 제외) }\end{array}$} & 7,118 & 1,957 & 287 & 429 & 825 & 1,053 & 1,695 & 872 \\
\hline & & $100 \%$ & $27.5 \%$ & $4.0 \%$ & $6.0 \%$ & $11.6 \%$ & $14.8 \%$ & $23.8 \%$ & $12.3 \%$ \\
\hline & \multirow{2}{*}{ 관광 운수업 } & 65,176 & 605 & 1,492 & 5,121 & 17,544 & 7,229 & 2,639 & 30,546 \\
\hline & & $100 \%$ & $0.9 \%$ & $2.3 \%$ & $7.9 \%$ & $26.9 \%$ & $11.1 \%$ & $4.0 \%$ & $46.9 \%$ \\
\hline & \multirow{2}{*}{ 관광 숙박업 } & 134,639 & 55,392 & 11,192 & 7,812 & 11,186 & 9,053 & 17,890 & 22,114 \\
\hline & & $100 \%$ & $41.1 \%$ & $8.3 \%$ & $5.8 \%$ & $8.3 \%$ & $6.7 \%$ & $13.3 \%$ & $16.4 \%$ \\
\hline & \multirow{2}{*}{$\begin{array}{c}\text { 관광 음식점 및 } \\
\text { 주점업 }\end{array}$} & 152,633 & 41,480 & 19,481 & 22,521 & 39,605 & 18,427 & 7,536 & 3,583 \\
\hline & & $100 \%$ & $27.2 \%$ & $12.8 \%$ & $14.8 \%$ & $25.9 \%$ & $12.1 \%$ & $4.9 \%$ & $2.3 \%$ \\
\hline & \multirow{2}{*}{$\begin{array}{c}\text { 여행사 및 여행보조 } \\
\text { 서비스업 }\end{array}$} & 49,870 & 16,616 & 7,105 & 5,485 & 8,080 & 3,755 & 5,064 & 3,765 \\
\hline & & $100 \%$ & $33.3 \%$ & $14.2 \%$ & $11.0 \%$ & $16.2 \%$ & $7.5 \%$ & $10.2 \%$ & $7.5 \%$ \\
\hline
\end{tabular}




\begin{tabular}{|c|c|c|c|c|c|c|c|c|c|}
\hline \multirow[b]{2}{*}{ 대분류 } & \multirow[b]{2}{*}{ 중분류 } & \multicolumn{8}{|c|}{ 규모별 종사자수 현황 } \\
\hline & & 전체 & 1 4인 & $5 \sim 9$ 인 & 10 19인 & 20 49인 & 50 99인 & $\begin{array}{c}100 \sim 299 \\
\text { 인 }\end{array}$ & $\begin{array}{c}300 \text { 인 } \\
\text { 이상 }\end{array}$ \\
\hline & \multirow{2}{*}{ 국제회의업a } & 4,713 & 368 & 507 & 605 & 969 & 352 & 809 & 1,103 \\
\hline & & $100 \%$ & $7.8 \%$ & $10.8 \%$ & $12.8 \%$ & $20.6 \%$ & $7.5 \%$ & $17.2 \%$ & $23.4 \%$ \\
\hline & \multirow{2}{*}{$\begin{array}{c}\text { 문화, 오락 및 레저 } \\
\text { 스포츠산업 }\end{array}$} & 108,038 & 10,786 & 7,058 & 6,642 & 11,868 & 14,915 & 40,795 & 15,974 \\
\hline & & $100 \%$ & $10.0 \%$ & $6.5 \%$ & $6.1 \%$ & $11.0 \%$ & $13.8 \%$ & $37.8 \%$ & $14.8 \%$ \\
\hline & \multirow{2}{*}{ 카지노업a } & 8,728 & - & - & - & - & - & 1,471 & 7,257 \\
\hline & & $100 \%$ & - & - & - & - & - & $16.9 \%$ & $83.1 \%$ \\
\hline \multirow{10}{*}{$\begin{array}{l}\text { 상호 } \\
\text { 의존 } \\
\text { 관광 } \\
\text { 산업 }\end{array}$} & \multirow{2}{*}{ 소계 } & 166,745 & 57,244 & 18,340 & 10,522 & 37,051 & 21,985 & 12,379 & 9,224 \\
\hline & & $100 \%$ & $34.3 \%$ & $11.0 \%$ & $6.3 \%$ & $22.2 \%$ & $13.2 \%$ & $7.4 \%$ & $5.5 \%$ \\
\hline & \multirow{2}{*}{ 관광 건설업 } & 13,299 & 3,453 & 6,122 & 1,747 & 575 & 813 & 589 & - \\
\hline & & $100 \%$ & $26.0 \%$ & $46.0 \%$ & $13.1 \%$ & $4.3 \%$ & $6.1 \%$ & $4.4 \%$ & - \\
\hline & \multirow{2}{*}{$\begin{array}{c}\text { 관광 및 레저용품 } \\
\text { 소매업 }\end{array}$} & 53,356 & 44,487 & 5,620 & 1,325 & 1,267 & 362 & 295 & - \\
\hline & & $100 \%$ & $83.4 \%$ & $10.5 \%$ & $2.5 \%$ & $2.4 \%$ & $0.7 \%$ & $0.6 \%$ & - \\
\hline & \multirow{2}{*}{$\begin{array}{l}\text { 관광 보험 및 } \\
\text { 금융서비스업 }\end{array}$} & 84,178 & 1,996 & 3,398 & 5,730 & 33,807 & 20,297 & 10,026 & 8,924 \\
\hline & & $100 \%$ & $2.4 \%$ & $4.0 \%$ & $6.8 \%$ & $40.2 \%$ & $24.1 \%$ & $11.9 \%$ & $10.6 \%$ \\
\hline & \multirow{2}{*}{ 레저장비업 } & 15,912 & 7,308 & 3,200 & 1,720 & 1,402 & 513 & 1,469 & 300 \\
\hline & & $100 \%$ & $45.9 \%$ & $20.1 \%$ & $10.8 \%$ & $8.8 \%$ & $3.2 \%$ & $9.2 \%$ & $1.9 \%$ \\
\hline \multirow{14}{*}{$\begin{array}{l}\text { 부분 } \\
\text { 적용 } \\
\text { 관광 } \\
\text { 산업 }\end{array}$} & \multirow{2}{*}{ 소계 } & $1,814,121$ & $1,061,200$ & 422,026 & 132,597 & 65,645 & 27,259 & 81,621 & 23,773 \\
\hline & & $100 \%$ & $58.5 \%$ & $23.3 \%$ & $7.3 \%$ & $3.6 \%$ & $1.5 \%$ & $4.5 \%$ & $1.3 \%$ \\
\hline & \multirow{2}{*}{ 관광 비인증 쇼핑업 } & 478,771 & 191,649 & 108,799 & 45,071 & 40,339 & 17,345 & 63,117 & 12,451 \\
\hline & & $100 \%$ & $40.0 \%$ & $22.7 \%$ & $9.4 \%$ & $8.4 \%$ & $3.6 \%$ & $13.2 \%$ & $2.6 \%$ \\
\hline & \multirow{2}{*}{ 부분관광 운송업 } & 46,610 & 4,792 & 2,834 & 6,311 & 4,987 & 4,865 & 13,611 & 9,210 \\
\hline & & $100 \%$ & $10.3 \%$ & $6.1 \%$ & $13.5 \%$ & $10.7 \%$ & $10.4 \%$ & $29.2 \%$ & $19.8 \%$ \\
\hline & \multirow{2}{*}{ 부분관광 숙박업 } & 47,695 & 32,599 & 7,038 & 2,389 & 3,046 & 1,389 & 1,234 & - \\
\hline & & $100 \%$ & $68.3 \%$ & $14.8 \%$ & $5.0 \%$ & $6.4 \%$ & $2.9 \%$ & $2.6 \%$ & - \\
\hline & \multirow{2}{*}{$\begin{array}{c}\text { 부분관광 음식점 및 } \\
\text { 주점업 }\end{array}$} & $1,214,221$ & 831,222 & 294,416 & 73,194 & 12,410 & 1,668 & 640 & 671 \\
\hline & & $100 \%$ & $68.5 \%$ & $24.2 \%$ & $6.0 \%$ & $1.0 \%$ & $0.1 \%$ & $0.1 \%$ & $0.1 \%$ \\
\hline & \multirow{2}{*}{ 부분관광 공연장업 } & 6,136 & 578 & 364 & 442 & 958 & 531 & 2,438 & 825 \\
\hline & & $100 \%$ & $9.4 \%$ & $5.9 \%$ & $7.2 \%$ & $15.6 \%$ & $8.7 \%$ & $39.7 \%$ & $13.4 \%$ \\
\hline & \multirow{2}{*}{$\begin{array}{c}\text { 부분관광 기타 } \\
\text { 서비스업 }\end{array}$} & 20,688 & 360 & 8,575 & 5,190 & 3,905 & 1,461 & 581 & 616 \\
\hline & & $100 \%$ & $1.7 \%$ & $41.4 \%$ & $25.1 \%$ & $18.9 \%$ & $7.1 \%$ & $2.8 \%$ & $3.0 \%$ \\
\hline \multirow{6}{*}{$\begin{array}{l}\text { 관광 } \\
\text { 지원 } \\
\text { 산업 }\end{array}$} & \multirow{2}{*}{ 소계 } & 418,564 & 49,505 & 16,178 & 11,842 & 30,992 & 22,012 & 48,945 & 239,090 \\
\hline & & $100 \%$ & $11.8 \%$ & $3.9 \%$ & $2.8 \%$ & $7.4 \%$ & $5.3 \%$ & $11.7 \%$ & $57.1 \%$ \\
\hline & \multirow{2}{*}{ 관광 연구 개발업 } & 3,774 & 226 & 217 & 197 & 419 & 437 & 1,019 & 1,259 \\
\hline & & $100 \%$ & $6.0 \%$ & $5.7 \%$ & $5.2 \%$ & $11.1 \%$ & $11.6 \%$ & $27.0 \%$ & $33.4 \%$ \\
\hline & \multirow{2}{*}{ 관광 공공기관 } & 146,270 & 1,352 & 4,833 & 7,810 & 27,684 & 16,921 & 31,783 & 55,887 \\
\hline & & $100 \%$ & $0.9 \%$ & $3.3 \%$ & $5.3 \%$ & $18.9 \%$ & $11.6 \%$ & $21.7 \%$ & $38.2 \%$ \\
\hline
\end{tabular}




\begin{tabular}{|c|c|c|c|c|c|c|c|c|c|}
\hline \multirow[b]{2}{*}{ 대분류 } & \multirow[b]{2}{*}{ 중분류 } & \multicolumn{8}{|c|}{ 규모별 종사자수 현황 } \\
\hline & & 전체 & 1 4인 & $5 \sim 9$ 인 & 10 19인 & $20 \sim 49$ 인 & 50 99인 & $\begin{array}{c}100 \sim 299 \\
\text { 인 }\end{array}$ & $\begin{array}{c}300 \text { 인 } \\
\text { 이상 }\end{array}$ \\
\hline & \multirow{2}{*}{ 관광 교육서비스업 } & 267,779 & 47,578 & 10,987 & 3,779 & 2,808 & 4,540 & 16,143 & 181,944 \\
\hline & & $100 \%$ & $17.8 \%$ & $4.1 \%$ & $1.4 \%$ & $1.0 \%$ & $1.7 \%$ & $6.0 \%$ & $67.9 \%$ \\
\hline & \multirow{2}{*}{ 관광 단체 } & 741 & 349 & 141 & 56 & 81 & 114 & - & - \\
\hline & & $100 \%$ & $47.1 \%$ & $19.0 \%$ & $7.6 \%$ & $10.9 \%$ & $15.4 \%$ & - & - \\
\hline \multirow{2}{*}{\multicolumn{2}{|c|}{ 전체 }} & $2,930,345$ & $1,295,153$ & 503,666 & 203,576 & 223,765 & 126,040 & 220,844 & 357,301 \\
\hline & & $100 \%$ & $44.2 \%$ & $17.2 \%$ & $6.9 \%$ & $7.6 \%$ & $4.3 \%$ & $7.5 \%$ & $12.2 \%$ \\
\hline
\end{tabular}

100 인 이상의 사업체수 누적비중은 $0.3 \%(1,832$ 개/722,853개)를 차지하고 있고 종사자수 누적비중은 $19.7 \%(578,145$ 명/2,930,345명)에 해당하며 사업체당 평균 종사자수는 315.6명(전체 평균은 4.05명)에 해당한다.

[그림 4-6] 관광산업(특수분류) 규모별 사업체수 누적과 종사자수 누적과의 관계

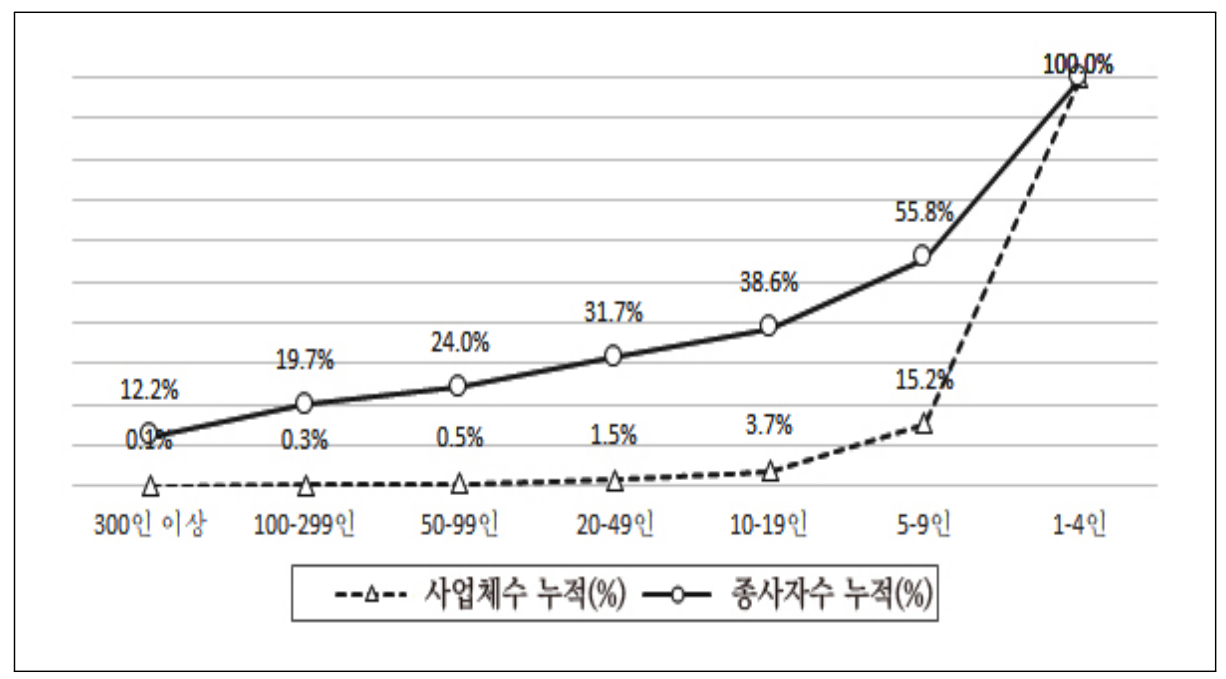

산업 전체에 대한 종사자수의 평균은 4.1 명, 변동계수는 평균의 7.8 배로 매우 크 게 나타나고 있다. 종사자수 규모를 100 인 기준으로 변동계수를 산출하면 100 인 미만은 $1.5,100$ 인 이상은 1.7 로 규모를 고려하지 않은 경우 대비 변동은 매우 작 아지게 된다. 
〈표 4-16〉 관광산업특수분류 전체의 평균 종사자수와 변동계수 현황

\begin{tabular}{|c|c|c|c|c|c|c|c|}
\hline \multirow[b]{2}{*}{ 대분류 } & \multirow[b]{2}{*}{ 중분류 } & \multicolumn{2}{|c|}{ 전체 } & \multicolumn{2}{|c|}{ 1 99인 } & \multicolumn{2}{|c|}{100 인 이상 } \\
\hline & & 평균 & $\begin{array}{l}\text { 변동 } \\
\text { 계수 }\end{array}$ & 평균 & $\begin{array}{l}\text { 변동 } \\
\text { 계수 }\end{array}$ & 평균 & $\begin{array}{l}\text { 변동 } \\
\text { 계수 }\end{array}$ \\
\hline \multirow{9}{*}{$\begin{array}{l}\text { 핵심 } \\
\text { 관광 } \\
\text { 산업 }\end{array}$} & 소계 & 6.8 & 9.5 & 4.8 & 1.9 & 269.6 & 2.5 \\
\hline & 관광 쇼핑업(도매업 제외) & 4.8 & 4.7 & 3.1 & 2.7 & 197.5 & 0.6 \\
\hline & 관광 운수업 & 41.7 & 9.5 & 20.9 & 0.8 & 1005.6 & 2.6 \\
\hline & 관광 숙박업 & 4.3 & 6.9 & 3.0 & 1.9 & 274.0 & 1.2 \\
\hline & 관광 음식점 및 주점업 & 6.2 & 2.4 & 5.8 & 1.7 & 191.7 & 0.8 \\
\hline & 여행사 및 여행보조 서비스업 & 4.9 & 3.7 & 4.1 & 1.8 & 245.3 & 0.6 \\
\hline & 국제회의업a & 13.9 & 3.6 & 8.4 & 1.4 & 273.1 & 0.8 \\
\hline & 문화, 오락 및 레저 스포츠산업 & 13.6 & 4.2 & 6.7 & 2.0 & 191.8 & 1.2 \\
\hline & 카지노업a & 545.5 & 1.4 & . & 0.0 & 545.5 & 1.4 \\
\hline \multirow{5}{*}{$\begin{array}{l}\text { 상호 } \\
\text { 의존 } \\
\text { 관광 } \\
\text { 산업 }\end{array}$} & 소계 & 4.8 & 4.0 & 4.2 & 2.0 & 232.3 & 1.1 \\
\hline & 관광 건설업 & 5.2 & 1.5 & 5.0 & 1.1 & 117.8 & 0.2 \\
\hline & 관광 및 레저용품 소매업 & 2.2 & 1.1 & 2.2 & 0.9 & 147.5 & 0.1 \\
\hline & 관광 보험 및 금융서비스업 & 25.7 & 2.2 & 20.4 & 1.0 & 243.0 & 1.1 \\
\hline & 레저장비업 & 3.6 & 3.0 & 3.2 & 1.4 & 221.1 & 0.3 \\
\hline \multirow{7}{*}{$\begin{array}{l}\text { 부분 } \\
\text { 적용 } \\
\text { 관광 } \\
\text { 산업 }\end{array}$} & 소계 & 3.1 & 2.4 & 3.0 & 1.1 & 182.3 & 0.6 \\
\hline & 관광 비인증 쇼핑업 & 4.1 & 3.1 & 3.5 & 1.4 & 170.6 & 0.5 \\
\hline & 부분관광 운송업 & 8.5 & 4.8 & 4.4 & 2.2 & 240.2 & 0.8 \\
\hline & 부분관광 숙박업 & 2.6 & 1.8 & 2.6 & 1.4 & 137.1 & 0.2 \\
\hline & 부분관광 음식점 및 주점업 & 2.8 & 0.8 & 2.8 & 0.8 & 187.3 & 0.6 \\
\hline & 부분관광 공연장업 & 13.7 & 3.1 & 6.7 & 1.8 & 191.9 & 0.5 \\
\hline & 부분관광 기타 서비스업 & 9.5 & 1.4 & 9.0 & 1.0 & 171.0 & 0.5 \\
\hline \multirow{5}{*}{$\begin{array}{l}\text { 관광 } \\
\text { 지원 } \\
\text { 산업 }\end{array}$} & 소계 & 13.3 & 7.9 & 4.2 & 2.1 & 518.1 & 1.2 \\
\hline & 관광 연구 개발업 & 18.6 & 3.2 & 7.7 & 1.9 & 253.1 & 0.6 \\
\hline & 관광 공공기관 & 42.1 & 2.7 & 18.3 & 1.0 & 314.2 & 0.8 \\
\hline & 관광 교육서비스업 & 9.7 & 10.7 & 2.5 & 1.6 & 739.1 & 1.0 \\
\hline & 관광 단체 & 3.6 & 1.9 & 3.6 & 1.9 & . & 0.0 \\
\hline 전체 & & 4.1 & 7.8 & 3.3 & 1.5 & 315.6 & 1.7 \\
\hline
\end{tabular}




\section{제2절 관광산업특수분류기준 표본설계}

\section{1. 표본설계 절차}

관광산업특수분류기준에 따른 표본설계 절차이다.

[그림 4-7] 관광산업특수분류기준에 따른 표본설계 절차

\begin{tabular}{|c|c|c|}
\hline 모집단 정의 & $\Rightarrow$ & $\begin{array}{l}\text { - 표본설계의 목표모집단과 조사모집단을 정의 } \\
\text { - 모집단의 가용한 정보수준을 파악 } \\
\text { (사업체 단위의 기준변수 활용, 층별 통계량 활용 가능성) }\end{array}$ \\
\hline \multicolumn{3}{|l|}{$\downarrow$} \\
\hline $\begin{array}{l}\text { 층화여부 및 } \\
\text { 층화변수 결정 }\end{array}$ & $\Rightarrow$ & $\begin{array}{l}\text { - 객관적인 층별 차이가 예상되는 경우는 층을 정의 } \\
\text { - 너무 세분화된 층은 오히려 표본수를 증가시키게 되어 부적절함 } \\
\text { ※ 단순임의추출 대비 적은 수의 표본이 되는지를 검토해야 함 }\end{array}$ \\
\hline \multicolumn{3}{|l|}{$\downarrow$} \\
\hline $\begin{array}{c}\text { 신뢰수준과 } \\
\text { 목표오차 수준 결정 }\end{array}$ & $\Rightarrow$ & $\begin{array}{l}\text { - 조사의 신뢰수준과 목표오차 수준을 결정 } \\
\text { - 본 연구에서는 신뢰수준 } 9 \% \text { 에서 목표오차수준을 } \pm 5 \% p \text { 내외 }\end{array}$ \\
\hline \multicolumn{3}{|l|}{$\downarrow$} \\
\hline $\begin{array}{c}\text { 표본배분방법론 } \\
\text { 결정 }\end{array}$ & $\Rightarrow$ & $\begin{array}{l}\text { - 모집단의 가용 정보와 표본배분방법별 효율성을 고려하여 적정 표본 } \\
\text { 배분방법을 선정 } \\
\text { (예) 동일 목표오차수준에서 표본수가 가장 적거나 총분산이 최소화되 } \\
\text { 는 표본배분방법론 선정(본 연구는 최소 표본수 기준 활용) }\end{array}$ \\
\hline \multicolumn{3}{|l|}{$\downarrow$} \\
\hline $\begin{array}{l}\text { 최종 표본수 } \\
\text { 결정 }\end{array}$ & $\Rightarrow$ & $\begin{array}{l}\text { - 설계된 층별로 최소한의 집계와 통계 산출을 위한 조사 표본수를 배분 } \\
\text { 하여 최종적인 표본수를 산출 }\end{array}$ \\
\hline
\end{tabular}




\section{2. 적정 표본크기 결정}

\section{가. 전체 산업의 표본규모 산정방법론}

본 조사에서 통계적 추론의 가장 중요한 대상이 되는 수치는 총매출액이다. 다만, 본 연구의 조사모집단에는 종사자수 정보만 존재하고 있다. 따라서 매출액 대신 연 관성이 높은 “종사자수 총계”를 추정하는 경우에 대하여 표본크기 문제를 고려한다.

표본크기는 표본추출방법과 모집단의 특성 및 층화방법 등의 영향을 받지만, 단 순임의추출의 상황 하에서 통계분석 단위별로 신뢰수준 $95 \%$ 에서 총합 추정치의 목 표오차수준 $B(=$ 총종사자수 $\times$ 목표오차(\%))를 어느 정도로 통제할 것인가에 따라 아 래 식으로 계산할 수 있다.

$$
n=\frac{N \sigma^{2}}{(N-1) D+\sigma^{2}}, \quad\left(\text { 단 }, D=\frac{B^{2}}{1.96^{2} \cdot N^{2}}\right)
$$

$$
\begin{aligned}
& \text { 여기서, } N \text { : 모집단의 크기 } \\
& \sigma^{2} \text { : 종사자수의 모분산 }
\end{aligned}
$$

표본조사 결과, 종사자수 $y$ 에 대하여 표본크기 $n$ 과 분산의 추정치 $s^{2}$ 이 주어진 경우, 모집단 종사자수 총합 $\tau$ 의 추정량 $\hat{\tau}=N \cdot \bar{y}=N \sum_{i=1}^{n} \frac{y_{i}}{n}$ 에 대한 추정오차의 한계는 다음과 같이 산출할 수 있다. 여기서, $y_{i}$ 는 $i$ 번째 사업체의 종사자수, $\bar{y}$ 는 평균 종사자수, $n$ 은 표본수를 나타낸다.

$$
B=z_{\alpha / 2} \sqrt{N^{2}\left(\frac{s^{2}}{n}\right)\left(\frac{N-n}{N}\right)}
$$

4단계 확대전략에 따른 모집단을 기준으로 종사자수 규모 300인 이상, 100 인 이 상, 50인 이상으로 전수조사 대상을 늘려가면서 나머지 표본층에 대해 표본수를 계 산하여 총 필요표본수를 산출하였다. 


\section{나. 확대전략별 표본규모 산정}

4개 확대전략 단계에 대하여 각각의 단계별

(1) 사업체 전체를 표본조사하는 경우

(2) 300 인 이상은 전수조사하고 300 인 미만에 대하여 표본조사하는 경우

(3) 100 인 이상은 전수조사하고 100 인 미만 사업체들은 표본조사하는 경우

(4) 50 인 이상은 전수조사하고 50 인 미만 사업체들은 표본조사 하는 경우

를 가정하여 표본조사 대상에 대하여 단순임의추출법(SRS; Simple Random Sampling)으로 표본수 산출식에 대입하여 적정 표본수를 계산하였다.

표본층의 산출된 표본수와 전수조사 대상 사업체수를 합하여 전체 표본수를 산출 하였다. 전체 표본수가 최소가 되는 규모를 확인하여 전수조사대상 규모를 검토하 였다.

산출된 표본수는 이론적인 절차를 통해 계산된 적정 표본수이다.

실제 조사에서 표본크기는 조사의 비용과 시간, 비표본오차 등을 종합적으로 고 려하여 선정해야 한다. 규모가 큰 사업체에 대한 전수조사 대상이 증가하게 되면 조사의 회수율이 낮아질 우려가 있고 규모가 크지 않은 표본조사 사업체에 비하여 조사관리의 어려움으로 인해 비표본오차가 증가할 수 있다.

신뢰수준 $95 \%$ 에서 목표오차수준을 $\pm 5 \% \mathrm{p}$ 기준으로 확대전략 4 개 단계 각각의 전체 필요 표본수를 산출하였다.

각 단계별로 전수조사층을 조정하면서 표본층에 대하여 단순임의추출법으로 적 정 표본수를 산출하였다. 전수조사 대상 사업체수와 산출된 표본수와 합산하여 전 체 필요 표본수를 산출하였다.

1) 1 단계: 핵심관광산업의 'a'코드 기준

핵심관광산업의 'a' 코드 기준 49,353 개 사업체를 모집단으로 설정하여 단순임의 추출법으로 표본수를 산출하였다. 
〈표 4-17〉1단계(핵심관광산업의 ‘a'코드 기준)의 규모구분별 표본수 산출

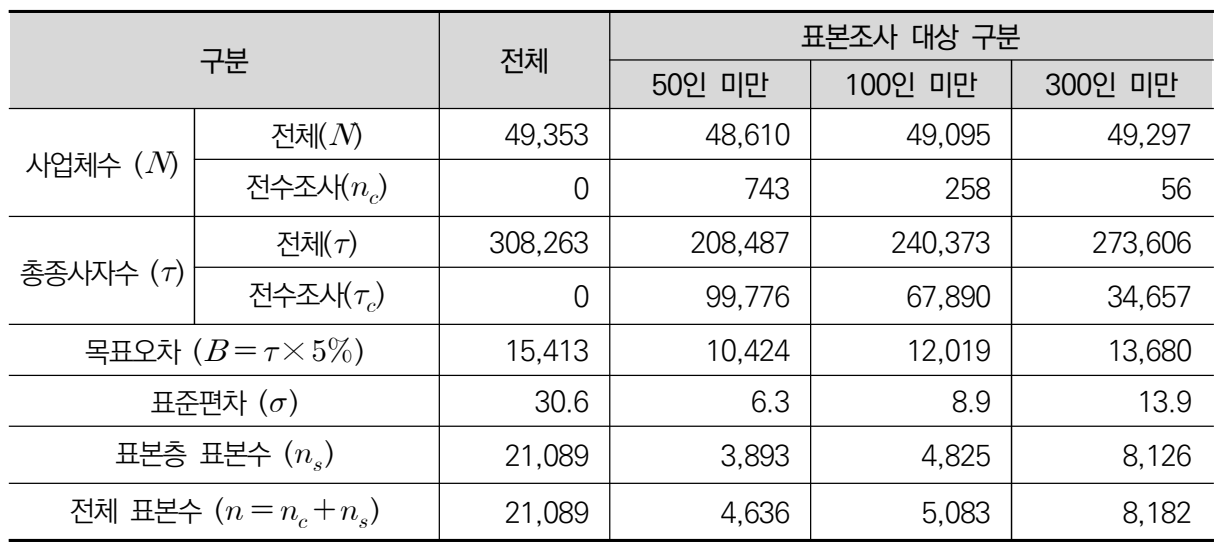

전수조사 대상별로 산출한 전체 표본수가 가장 적은 기준은 종사자수 50인을 기 준으로 전수층과 표본층을 구분하는 것이다. 그러나 전수조사 대상을 100 인 이상으 로 조정하는 경우 전수조사 사업체는 485 개가 감소하고 전체 표본은 447개만 증가 하여 조사의 효율성을 고려할 때 100 인 이상을 전수조사대상으로 정의하는 것이 타당할 것이다.

\section{2) 2단계: 핵심관광산업 전체}

핵심관광산업 전체 77,705 개 사업체를 모집단으로 설정하여 단순임의추출법으 로 표본수를 산출하였다.

〈표 4-18〉2단계(핵심관광산업)의 규모구분별 표본수 산출

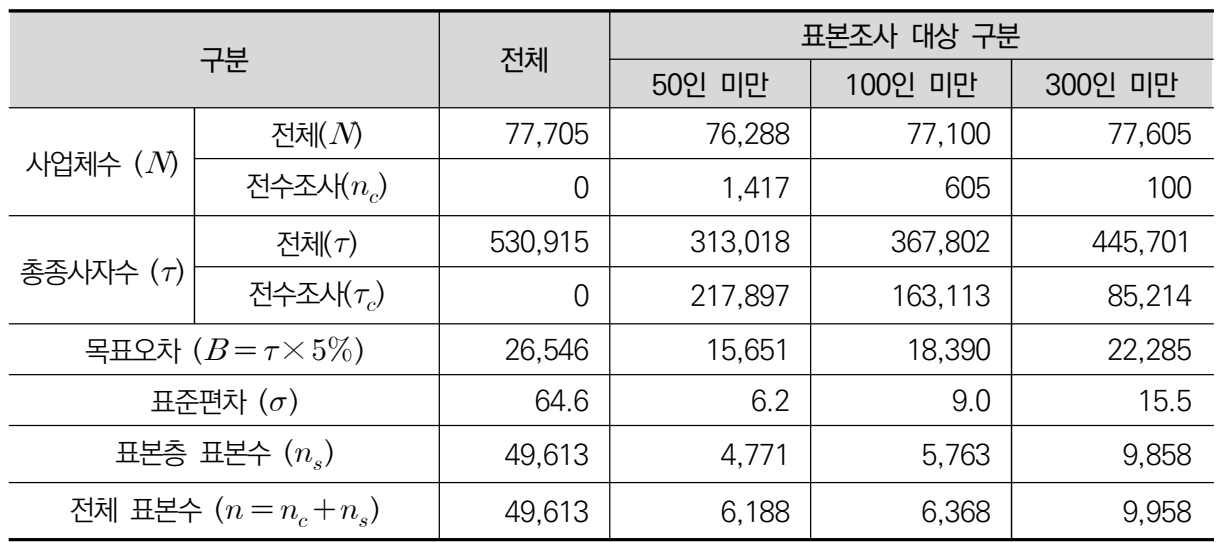


전수조사 대상별로 산출한 전체 표본수가 가장 적은 기준은 종사자수 50인을 기 준으로 전수층과 표본층을 구분하는 것이다. 그러나 전수조사 대상을 100 인 이상으 로 조정하는 경우 전수조사 사업체는 812 개가 감소하고 전체 표본은 180 개만 증가 하여 조사의 효율성을 고려할 때 100 인 이상을 전수조사대상으로 정의하는 것이 타당할 것이다.

\section{3) 3 단계: 품목분석의 관광산업 구분}

품목분석에서 관광산업으로 구분되는 147,052 개 사업체를 모집단으로 설정하여 단순임의추출법으로 표본수를 산출하였다.

〈표 4-19〉3단계(품목분석의 관광산업 구분)의 규모구분별 표본수 산출

\begin{tabular}{|c|c|c|c|c|c|}
\hline \multirow{2}{*}{\multicolumn{2}{|c|}{ 구분 }} & \multirow{3}{*}{$\begin{array}{l}\text { 전체 } \\
147,052\end{array}$} & \multicolumn{3}{|c|}{ 표본조사 대상 구분 } \\
\hline & & & \multirow{2}{*}{$\begin{array}{r}\text { 50인 미만 } \\
145,858\end{array}$} & \multirow{2}{*}{$\begin{array}{r}100 \text { 인 미만 } \\
146,439\end{array}$} & \multirow{2}{*}{$\begin{array}{r}300 \text { 인 미만 } \\
146,943\end{array}$} \\
\hline & 전체 $(N)$ & & & & \\
\hline ㄱㅂㅅㅣ (V) & 전수조사 $\left(n_{c}\right)$ & 0 & 1,194 & 613 & 109 \\
\hline \multirow{2}{*}{ 총종사자수 $(\tau)$} & 전체 $(\tau)$ & 607,620 & 396,417 & 436,665 & 514,692 \\
\hline & 전수조사 $\left(\tau_{c}\right)$ & 0 & 211,203 & 170,955 & 92,928 \\
\hline \multicolumn{2}{|c|}{ 목표오차 $(B=\tau \times 5 \%)$} & 30,391 & 19,821 & 21,833 & 25,735 \\
\hline \multicolumn{2}{|c|}{ 표준편차 $(\sigma)$} & 47.5 & 4.0 & 5.9 & 11.0 \\
\hline \multicolumn{2}{|c|}{ 표본층 표본수 $\left(n_{s}\right)$} & 85,304 & 4,494 & 6,339 & 13,818 \\
\hline \multicolumn{2}{|c|}{ 전체 표본수 $\left(n=n_{c}+n_{s}\right)$} & 85,304 & 5,688 & 6,952 & 13,927 \\
\hline
\end{tabular}

전수조사 대상별로 산출한 전체 표본수가 가장 적은 기준은 종사자수 50인을 기 준으로 전수층과 표본층을 구분하는 것이다. 만약 전수조사 대상을 100 인 이상으로 조정하는 경우 전수조사 사업체는 582 개가 감소하는 반면, 전체 표본은 1,264 개가 증가하여 조사의 효율성을 고려할 때 50 인 이상을 전수조사대상으로 정의하는 것이 타당할 것이다. 


\section{4) 4단계: 관광특수분류 전체}

관광특수분류 전체 722,853 개 사업체를 모집단으로 설정하여 단순임의추출법으 로 표본수를 산출하였다.

〈표 4-20〉4단계(관광산업특수분류 전체)의 규모구분별 표본수 산출

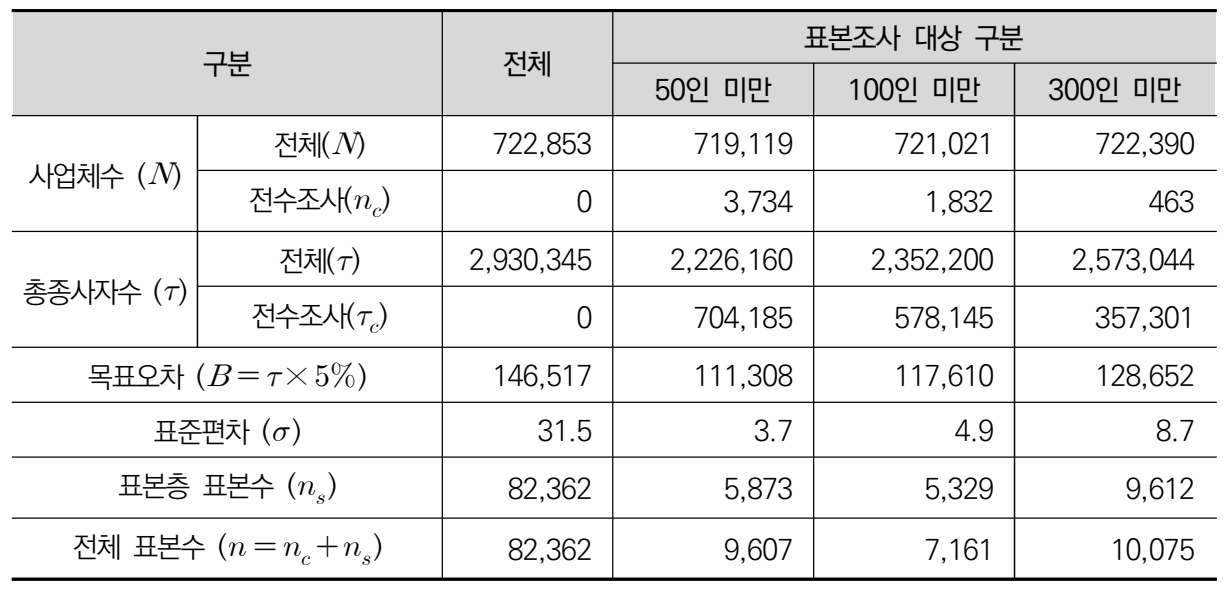

전수조사 대상별로 산출한 전체 표본수가 가장 적은 기준은 종사자수 100 인을 기준으로 전수층과 표본층을 구분하는 것이다. 만약 전수조사 대상을 300 인 이상으 로 조정하는 경우 전수조사 사업체는 1,369 개가 감소하는 반면, 전체 표본은 2,915 개가 증가하여 조사의 효율성을 고려할 때 100 인 이상을 전수조사대상으로 정의하 는 것이 타당할 것이다.

\section{3. 층화추출법 적용}

관광산업특수분류에 따라 통계의 차이가 발생하고 특히, 종사자수 규모에 따라 차이가 발생하고 있음을 알 수 있었다. 따라서 본 연구와 같이 층화기준이 명확한 경우에는 전체를 모집단으로 설정하여 단순임의추출법을 적용한 것 보다 층화추출 법을 적용하는 것이 타당할 것이다. ${ }^{13)}$

13) 설계효과(DEFF; Design Effect)는 주어진 표본설계에서의 표본분산을 단순임의추출 하에서의 표본분산 
표본층화추출법은 모집단을 유사한 특성을 가진 여러 개의 중복되지 않는 부모집 단(Subpopulation)을 층(Stratum)으로 나누고(층화; Stratification) 각 층에서 표본을 추출하여 모집단의 특성치를 추정하는 것을 말한다.

본 연구에서 층화기준의 검토는 관광특수분류체계의 확대 전략중 2단계(핵심산 업 전체)와 4단계(관광산업특수분류 전체)로 확대하는 것을 기준으로 결정하였다.

\section{가. 층화변수 정의}

조사내용의 특성과 모집단에 대한 대표성을 높이기 위해 종사자 수와 산업 구분 을 층화변수로 고려한다. 층화변수들은 다음과 같다.

(1) 종사자수 규모: 100 인 이상, 100 인 미만

(5개 규모 구분; 1 4인, 5 9인, 10 19인, 20 49인, 50 99인)

(2) 산업: 관광산업특수분류 중분류 및 소분류(현행 관광산업실태조사의 기준 적용)

(3) 지역: 17개 광역자치단체 (세종특별자치시 포함)

중분류 산업별로 지역별 통계 산출을 위한 최소 사업체수를 고려하여 전수조사 대상을 선정하였다.14) 또한 종사자수가 100 인 이상인 사업체들에 대해서도 전수조 사 대상으로 설정하였다. ${ }^{15)}$

으로 나눈 값으로서 보통, 주어진 표본설계가 단순임의추출일 경우 deff $=1$, 층화추출일 경우 DEFF $\leq 1$, 그리고 집락추출일 경우 $\mathrm{DEFF} \geq 1$ 값을 가진다(보건사회연구원, 2006, p.36).

$14)$ 중분류 산업별로 지역을 고려하여 최소 34 개 $(=17$ 개 $\times 2$ 개 $)$ 미만인 경우 전수조사 하도록 함

15) 확대전략 4단계별로 전수조사 규모구분은 3 단계를 제외하고 100 인 이상으로 산출되었다. 
〈표 4-21〉 확대전략별 전수조사 대상 선정

\begin{tabular}{|c|c|c|c|}
\hline 단계 & 구분 & 대상 & 사업체수 \\
\hline \multirow{3}{*}{ 1단계 } & 중분류 최소 사업체수 & 306. 기타 관광서비스업 & $3(0)$ \\
\hline & 100인 구분 & 100 인 이상 & 258 \\
\hline & \multicolumn{2}{|c|}{ 계 } & 261 \\
\hline \multirow{3}{*}{ 2단계 } & 중분류 최소 사업체수 & 108. 카지노업 & $16(16)$ \\
\hline & 100인 구분 & 100인 이상 & 605 \\
\hline & \multicolumn{2}{|c|}{ 계 } & 605 \\
\hline \multirow{5}{*}{ 3단계 } & \multirow{3}{*}{ 중분류 최소 사업체수 } & 108. 카지노업 & $16(16)$ \\
\hline & & 301. 관광 비인증 쇼핑업 & $5(0)$ \\
\hline & & 401. 관광 연구 개발업 & $26(4)$ \\
\hline & 100인 구분 & 100인 이상 & 613 \\
\hline & \multicolumn{2}{|c|}{ 계 } & 640 \\
\hline \multirow{3}{*}{ 4단계 } & 중분류 최소 사업체수 & 108. 카지노업 & $16(16)$ \\
\hline & 100인 구분 & 100인 이상 & 1,832 \\
\hline & \multicolumn{2}{|c|}{ 계 } & 1,832 \\
\hline
\end{tabular}

( )안은 100 인 이상 사업체수

\section{나. 표본배분방법별 표본수 산출방법론}

층화추출에서 표본의 배분방법은 총 표본크기를 각 층에 합리적으로 배분하는 방 법이다. 표본배분방법은 층의 크기에 따라 배분하는 비례배분법과 층내 변동에 최 적 표본을 배분하는 네이만배분법이 있다. 기준변수의 크기 기준으로 전수층과 표 본층을 구분하면서 최적 표본를 배분하는 수정절사법이 있다. 모집단에 대한 정보 의 양을 기준으로 비례배분법은 층별 사업체수, 네이만배분법은 층별 표준편차, 수 정절사법은 사업체별 기준변수의 값이 각각 요구된다.

$$
n_{h}=\left\{\begin{aligned}
n \cdot N_{h} S_{h} / \sum_{h=1}^{L} N_{h} S_{h}, & \text { 네이 만배분법 } \\
n \cdot N_{h} / \sum_{h=1}^{L} N_{h}, & \text { 비례 배분법 }
\end{aligned}\right.
$$




\section{1) 비례배분법(Proportional Allocation)}

부모집단의 사업체수에 비례적으로 배분하는 방법으로 층내 변동에 대한 정보가 부족하거나 없는 경우 활용하며 모집단에 대한 각 층의 크기에 비례하여 배정하는 방법으로 배분이 쉽고 집계가 용이하며 층의 크기에 따라 변동도 비례한다는 가정 을 전제로 한다.

표본수결정 공식은 다음과 같다.

$$
n=\frac{\sum_{h=1}^{L} N_{h} S_{h}^{2}}{N D+\frac{1}{N} \sum_{h=1}^{L} N_{h} S_{h}^{2}}
$$

여기서 $h \quad$ : 부모집단(층)을 나타내는 첨자

$N_{h} \quad$ : 부모집단별 모집단 사업체수

$S_{h} \quad$ : 부모집단별 표준편차

$D \quad: B^{2} / k^{2} \cdot N^{2}$ (단, $B$ 는 총합 추정오차의 한계,

$k$ 는 신뢰계수( $95 \%$ 신뢰수준의 경우 약 1.96)

2) 네이만배분법(Neyman Allocation)은

부모집단의 사업체수와 변동에 따라 비례적으로 배분하는 최적배분법의 특수한 경우로 볼 수 있다. 최적배분법은 표본의 크기를 일정한 비용하에서 분산을 최소로 하여 층에 배정하거나 일정한 분산하에서 비용을 최소로 하는 표본크기를 결정하는 방법이다. 네이만배분법은 최적배분법의 특수한 경우로 표본의 크기를 일정하게 정 하고 추정량의 분산을 보다 작게하여 정도를 높인 배분법이다(Lohr, 2009).

표본수결정 공식은 다음과 같다.

$$
n=\frac{\left(\sum_{h=1}^{L} N_{h} S_{h}\right)^{2}}{N^{2} D+\sum_{h=1}^{L} N_{h} S_{h}^{2}}
$$




\section{3) 수정절사법(Modified Cutoff Sampling Method)}

기준변수의 크기순으로 전수층과 표본층으로 구분하도록 배분하는 방법이며 모 집단의 특성치의 분포가 한쪽으로 편중되어 있고, 소규모 추출단위의 표본틀에 대 해 신뢰성이 없는 경우에 주로 사용한다. 그러나, 급성장하여 특성치의 크기가 상당 히 커진 추출단위가 절사된 소규모 층에 포함됐을 경우에는 좋은 추정치를 얻을 수 없으므로, 변화가 심한 모집단의 경우에는 주의하여야 한다.

일반적으로 대규모 층이 전체 모집단의 추정에 미치는 영향이 $90 \%$ 이하일 경우 에는 절사법이 적합하지 않다(Hansen, Hurwits and Madow, 1953). 이러한 절 사법을 보완한 것으로 수정절사법이 있다. 이 방법은 전체 추정에 상당한 기여를 하는 대규모 층은 전수조사를 하고, 모집단 추정에 큰 영향이 없는 소규모 층(표본 층)에서는 표본을 추출하여 대규모층(전수층)의 부족한 범위(coverage)를 보완하도 록 하는 표본설계방법이다.(Hidiroglou, 1986).

이는 원래의 절사법을 약간 변형시킨 것으로 모집단 추정에도 무리가 없고, 표본 크기를 축소하는 효과를 가져오며, 소규모 추출단위의 표본틀에 대해 신뢰성이 있 는 경우에 사용하면 절사법보다 효율적이다. 수정절사법에 의한 표본설계는 동일한 허용오차 범위 내에서 최소가 되는 표본크기를 찾을 수 있으며, 대규모 층에 포함되 는 추출단위가 전체 모집단에 기여하는 비중이 커서 표본관리를 집중적으로 할 수 있고, 최소의 표본크기이므로 조사업무의 부담이 줄어 비표본오차를 줄이는 효과가 있다(통계청, 1998).

수정절사법에 의한 총 표본크기는 전수층의 표본크기와 표본층의 표본크기를 합 하여 구한다.

$$
n=n_{c}+n_{s}
$$

$$
\begin{array}{cl}
\text { 여기서 } n_{c} & \text { : 전수층의 표본크기 }\left(=N_{c}=N-N_{s}\right) \\
n_{s} & : \text { 표본층의 표본수 }
\end{array}
$$

표본수의 결정은 추출단위를 특성치의 크기 순으로 나열한 다음, 주어진 표본오차 (허용오차)와 신뢰수준에서 표본층의 표본크기 $\left(n_{s}\right)$ 를 구한 후, 표본크기인 $n\left(=n_{c}+n_{s}\right)$ 
이 최소가 되는 절사점(Cutoff Point)을 정한다. 이 절사점을 중심으로 전수층 표본 층 $\left(n_{s}\right)$ 으로 구별하여, 절사점 상위의 전수층에 속하는 추출단위는 모두 표본에 포함 시키고, 절사점 이하의 표본층에서는 비복원으로 표본을 계통추출한다. 표본층의 표본수결정공식은 다음과 같다.

$$
n_{s}=\frac{k^{2}\left(Q_{m} \cdot C V_{m}\right)^{2} / E^{2}}{1+\left\{k^{2}\left(Q_{m} \cdot C V_{m}\right)^{2} / N_{m} \cdot E^{2}\right\}}
$$

여기서 $k \quad$ : 신뢰계수, $95 \%$ 신뢰수준의 경우 약 1.96

$m \quad$ : 전수조사 대상으로 $m=1,2, \ldots, N$

$Q_{m} \quad$ : 전체 특성치 중에서 $m$ 번째 이후 특성치의 비중

$$
=1 \text {-전수층의 특성치 비중 }\left(P_{m}=\sum_{i=1}^{m-1} y_{i} / \sum_{i=1}^{N} y_{i}\right)
$$

$C V_{m} \quad: m$ 번째에서 $N$ 번째까지의 특성치 변동계수

$E \quad$ : 상대오차수준 (\%)

$N_{m} \quad: m$ 번째에서 $N$ 번째까지의 모집단 사업체수 $(=N-m)$

\section{다. 층화변수의 적정성 검토}

정의한 층화변수들에 대하여 확대 전략 2단계(관광산업특수분류 핵심산업 전체) 와 4단계(관광산업특수분류 전체)에 대하여 층화변수의 적정성을 검토하였다.

\section{1) 2 단계(관광산업특수부류 핵심산업 전체)의 층화기준 검토}

관광산업특수분류 핵심산업 전체를 대상으로 100 인 이상 사업체 605 개를 제외 한 77,100 개 표본사업체를 대상으로 층화변수와 규모구분의 조합에 대해 표본수를 산출하여 비교하였다.

산업별, 규모별, 지역별로 층화변수의 적정성을 도출하기 위해 산업분류와 지역 구분의 4 가지 조합에 대해 규모 구분 각 3 가지를 고려하여 전체 12 가지 경우의 수 에 대하여 비례배분법으로 표본수를 산출하였다. 
〈표 4-22〉 층화변수의 적정성 검토 기준 (2단계: 핵심산업 전체)

\begin{tabular}{|c|c|c|c|c|c|}
\hline \multirow[b]{2}{*}{ 시나리오 } & \multirow[b]{2}{*}{ 산업분류 } & \multirow[b]{2}{*}{ 지역구분 } & \multicolumn{3}{|c|}{ 규모구분 } \\
\hline & & & 2개 (50인) & 3 개 (10인, 50인) & $\begin{array}{c}\text { 5개 (5인, } 10 \text { 인, } \\
20 \text { 인, } 50 \text { 인) }\end{array}$ \\
\hline 1 & \multirow{6}{*}{$\begin{array}{c}\text { 중분류 } \\
\text { (7개) }\end{array}$} & \multirow{3}{*}{$\begin{array}{l}\text { 전국 } \\
\text { (1개) }\end{array}$} & $\bigcirc$ & & \\
\hline 2 & & & & $\bigcirc$ & \\
\hline 3 & & & & & 0 \\
\hline 4 & & \multirow{3}{*}{$\begin{array}{c}\text { 시도 } \\
\text { (17개) }\end{array}$} & $\bigcirc$ & & \\
\hline 5 & & & & 0 & \\
\hline 6 & & & & & 0 \\
\hline 7 & \multirow{6}{*}{$\begin{array}{l}\text { 소분류 } \\
\text { (24개) }\end{array}$} & \multirow{3}{*}{$\begin{array}{l}\text { 전국 } \\
\text { (1개) }\end{array}$} & $\bigcirc$ & & \\
\hline 8 & & & & $\bigcirc$ & \\
\hline 9 & & & & & 0 \\
\hline 10 & & \multirow{3}{*}{$\begin{array}{c}\text { 시도 } \\
\text { (17개) }\end{array}$} & $\bigcirc$ & & \\
\hline 11 & & & & $\bigcirc$ & \\
\hline 12 & & & & & 0 \\
\hline
\end{tabular}

* 2개 (50인): 50인 미만, 50인 이상

* 3개 (10인, 50인): 1 9인, 10 49인, 50인 이상

* 5개 (5인, 10인, 20인, 50인): 1 4인, 5 9인, 10 19인, 20 49인, 50인 이상 [통계청 종사자수 규모 구분을 적용]

산업은 중분류(7개), 소분류(24개16)), 지역은 전국(1개), 시도(17개), 규모구분은 2 개 규모, 3 개 규모, 5 개 규모로 층을 세분화하면서 비례배분법으로 적정표본수를 산출하였다. ${ }^{17)}$ 적정표본수는 규모구분을 세분화 할수록 최소한의 집계를 위한 최소 표본의 할당이 급격히 증가하게 되고, 층이 세분화되면서 층내 분산이 작아져 표본 층의 표본수는 상대적으로 감소하게 된다.

16) 22 개 중분류 중에서 카지노업은 전체 16 개 사업체가 종사자수 100 인 이상 규모임

17) 층별로 모집단 사업체수가 3 개 미만이면 전수조사하고, 최종 배분된 표본은 최소 3 개 이상이 되도록 함. 
[그림 4-8] 층화기준에 따른 전수표본의 변화 (2단계: 핵심산업)

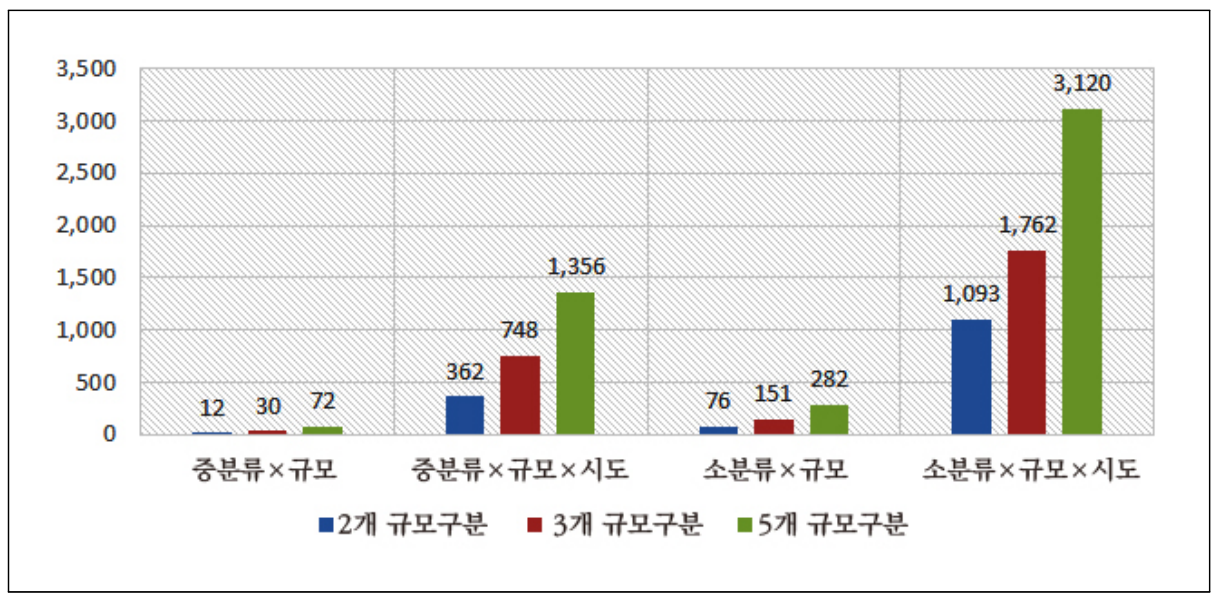

동일한 목표오차수준에서 전수조사 대상의 증가는 비표본오차의 증가를 초래하 여 전체 오차수준의 증가와 더불어 이를 통제하기 위한 조사비용의 증가로 이어질 수 있다. 따라서 적절한 규모구분을 선정하는 것이 중요할 것이다. 규모구분을 고려 할 때 50 인을 기준으로 50 인 미만과 50 인 이상으로 구분하는 경우가 적절할 것으 로 사료된다.

〈표 4-23〉 비례배분법의 층구분별 표본수 현황 (2단계: 핵심산업 전체)

\begin{tabular}{c|c|c|c|c|c}
\hline \multirow{2}{*}{ 규모 개수 } & \multirow{2}{*}{ 규모 구분 } & \multicolumn{4}{|c}{ 표본수 산출 결과 } \\
\cline { 3 - 6 } & & 전체 & 100인 이상 & 전수조사 & 표본조사 \\
\hline 2개 & 50인 & 3,616 & 605 & 1,093 & 1,918 \\
\hline 3개 & 10인, 50인 & 3,082 & 605 & 1,762 & 715 \\
\hline 5개 & 5인, 10인, 20인, 50인 & 4,075 & 605 & 3,120 & 350 \\
\hline
\end{tabular}

* (소분류×규모×시도에 대해 신뢰수준 $95 \%$ 에서 목표오차 수준=5\% 기준)

전수조사대상의 응답률이 $100 \%$ 인 경우 신뢰수준 95\%에서 목표오차수준 5\%p (절대오차=총종사자수 $[530,915$ 명 $\times 5 \%=26,546$ 명)을 달성할 수 있다. 그러나 전수 조사대상이 규모가 큰 사업체들로 구성되어 $100 \%$ 응답률을 기대하는 것은 현실적 으로 매우 어렵다. 응답률에 따른 절대오차의 크기는 커질 수밖에 없다. 즉, 절대오 차는 전수조사 대상 605 개 사업체의 총종사자수(163,113명) 대비 무응답률만큼 증 가하게 된다. 
〈표 4-24〉 2단계(핵심산업 전체)의 전수조사 응답률에 따른 표본수 변화

\begin{tabular}{|c|c|c|c|c|c|c|}
\hline \multirow{2}{*}{\multicolumn{2}{|c|}{ 구분 }} & \multicolumn{5}{|c|}{ 전수조사 대상의 응답률 } \\
\hline & & $100 \%$ & $95 \%$ & $90 \%$ & $85 \%$ & $80 \%$ \\
\hline \multicolumn{2}{|c|}{ 절대오차 (명) } & 26,546 & 34,701 & 42,857 & 51,013 & 59,168 \\
\hline \multicolumn{2}{|c|}{$100 \%$ 응답률 대비 오차 변화율 } & 1.00 & 1.31 & 1.61 & 1.92 & 2.23 \\
\hline \multirow{3}{*}{ 표본수의 변화 } & 규모 2개 & 3,616 & 4,727 & 5,838 & 6,949 & 8,060 \\
\hline & 규모 3개 & 3,082 & 4,029 & 4,976 & 5,923 & 6,870 \\
\hline & 규모 5개 & 4,075 & 5,327 & 6,579 & 7,831 & 9,083 \\
\hline
\end{tabular}

* (소분류×규모×시도에 대해 신뢰수준 $95 \%$ 에서 목표오차 수준=5\% 기준)

\section{2) 4 단계(관광산업특수부류 전체)의 층화기준 검토}

관광산업특수분류 전체를 대상으로 100 인 이상 사업체 1,832 개를 제외한 721,021 개 표본사업체를 대상으로 층화변수와 규모구분의 조합에 대해 표본수를 산출하여 비교하였다.

산업별, 규모별, 지역별로 층화변수의 적정성을 도출하기 위해 산업분류와 지역 구분의 4 가지 조합에 대해 규모 구분 각 3 가지를 고려하여 전체 12 가지 경우의 수 에 대하여 비례배분법으로 표본수를 산출하였다.

〈표 4-25〉 층화변수의 적정성 검토 기준 (4단계: 관광산업특수분류 전체)

\begin{tabular}{|c|c|c|c|c|c|}
\hline \multirow[b]{2}{*}{ 시나리오 } & \multirow[b]{2}{*}{ 산업분류 } & \multirow[b]{2}{*}{ 지역구분 } & \multicolumn{3}{|c|}{ 규모구분 } \\
\hline & & & 2개 (50인) & 3개 (10인, 50인) & $\begin{array}{c}\text { 5개 (5인, } 10 \text { 인, } \\
\text { 20인, } 50 \text { 인) }\end{array}$ \\
\hline 1 & \multirow{6}{*}{$\begin{array}{c}\text { 중분류 } \\
\text { (4개) }\end{array}$} & \multirow{3}{*}{$\begin{array}{l}\text { 전국 } \\
\text { (1개) }\end{array}$} & $\bigcirc$ & & \\
\hline 2 & & & & $\bigcirc$ & \\
\hline 3 & & & & & 0 \\
\hline 4 & & \multirow{3}{*}{$\begin{array}{c}\text { 시도 } \\
\text { (17개) }\end{array}$} & 0 & & \\
\hline 5 & & & & $\bigcirc$ & \\
\hline 6 & & & & & 0 \\
\hline 7 & \multirow{6}{*}{$\begin{array}{l}\text { 중분류 } \\
\text { (21개) }\end{array}$} & \multirow{3}{*}{$\begin{array}{l}\text { 전국 } \\
\text { (1개) }\end{array}$} & $\bigcirc$ & & \\
\hline 8 & & & & $\bigcirc$ & \\
\hline 9 & & & & & $\bigcirc$ \\
\hline 10 & & \multirow{3}{*}{$\begin{array}{c}\text { 시도 } \\
\text { (17개) }\end{array}$} & 0 & & \\
\hline 11 & & & & 0 & \\
\hline 12 & & & & & 0 \\
\hline
\end{tabular}

* 2개 (50인): 50인 미만, 50 인 이상

* 3개 (10인, 50인): 1 9인, 10 49인, 50인 이상

* 5개 (5인, 10인, 20인, 50인): 1 4인, 5 9인, 10 19인, 20 49인, 50인 이상

[통계청 종사자수 규모 구분을 적용] 
산업은 대분류(4개), 중분류(21개18)), 지역은 전국(1개), 시도(17개), 규모구분은 2 개 규모, 3 개 규모, 5 개 규모로 층을 세분화하면서 비례배분법으로 적정표본수를 산출하였다.19) 적정표본수는 규모구분을 세분화 할수록 최소한의 집계를 위한 최소 표본의 할당이 급격히 증가하게 되고, 층이 세분화되면서 층내 분산이 작아져 표본 층의 표본수는 상대적으로 감소하게 된다.

[그림 4-9] 층화기준에 따른 전수표본의 변화 (4단계: 관광산업특수분류 전체)

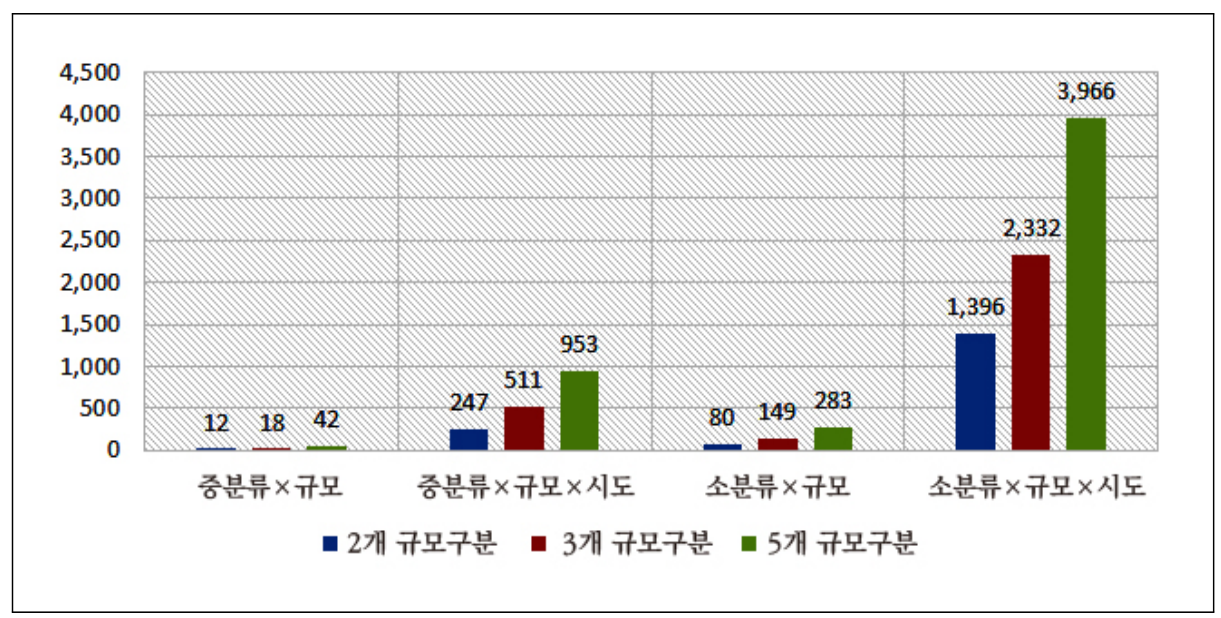

동일한 목표오차수준에서 전수조사 대상의 증가는 비표본오차의 증가를 초래하 여 전체 오차수준의 증가와 더불어 이를 통제하기 위한 조사비용의 증가로 이어질 수 있다. 따라서 적절한 규모구분을 선정하는 것이 중요할 것이다. 결과에서 규모구 분을 고려할 때 50 인을 기준으로 50 인 미만과 50 인 이상으로 구분하는 경우가 적 절할 것으로 사료된다.

18) 22 개 중분류 중에서 카지노업은 전체 16 개 사업체가 종사자수 100 인 이상 규모임

19) 층별로 모집단 사업체수가 3 개 미만이면 전수조사하고, 최종 배분된 표본은 최소 3 개 이상이 되도록 함. 
〈표 4-26〉 비례배분법의 층구분별 표본수 현황 (4단계: 관광산업특수분류 전체)

\begin{tabular}{c|c|c|c|c|c}
\hline \multirow{2}{*}{ 규모 개수 } & \multirow{2}{*}{ 규모 구분 } & \multicolumn{4}{|c}{ 표본수 산출 결과 } \\
\cline { 3 - 6 } & & 전체 & 100인 이상 & 전수조사 & 표본조사 \\
\hline 2개 & 50인 & 4,857 & 1,832 & 1,396 & 1,629 \\
\hline 3개 & 10인, 50인 & 4,896 & 1,832 & 2,332 & 732 \\
\hline 5개 & 5인, 10인, 20인, 50인 & 6,143 & 1,832 & 3,966 & 345 \\
\hline
\end{tabular}

* (중분류×규모×시도에 대해 신뢰수준 $95 \%$ 에서 목표오차 수준 $=5 \%$ 기준)

전수조사대상의 응답률이 $100 \%$ 인 경우 신뢰수준 $95 \%$ 에서 목표오차수준 5\%p (절대오차=총종사자수 $[2,930,345$ 명 $\times 5 \%=146,517$ 명)를 달성할 수 있다. 그러나 전수조사대상이 규모가 큰 사업체들로 구성되어 $100 \%$ 응답률을 기대하는 것은 현 실적으로 매우 어렵다. 응답률에 따른 절대오차의 크기는 커질 수밖에 없다. 즉, 절 대오차는 전수조사 대상 1,832 개 사업체의 총종사자수(578,145명) 대비 무응답률 만큼 증가하게 된다.

〈표 4-27〉 4단계(관광산업특수분류 전체)의 전수조사 응답률에 따른 표본수 변화

\begin{tabular}{|c|c|c|c|c|c|c|}
\hline \multirow{2}{*}{\multicolumn{2}{|c|}{ 구분 }} & \multicolumn{5}{|c|}{ 전수조사 대상의 응답률 } \\
\hline & & $100 \%$ & $95 \%$ & $90 \%$ & $85 \%$ & $80 \%$ \\
\hline \multicolumn{2}{|c|}{ 절대오차 (명) } & 146,517 & 175,425 & 204,332 & 233,239 & 262,146 \\
\hline \multicolumn{2}{|c|}{$100 \%$ 응답률 대비 오차 변화율 } & 1.00 & 1.20 & 1.39 & 1.59 & 1.79 \\
\hline \multirow{3}{*}{ 표본수의 변화 } & 규모 2개 & 4,857 & 5,815 & 6,774 & 7,732 & 8,690 \\
\hline & 규모 3개 & 4,896 & 5,862 & 6,828 & 7,794 & 8,760 \\
\hline & 규모 5개 & 6,143 & 7,355 & 8,567 & 9,779 & 10,991 \\
\hline
\end{tabular}

* (중분류×규모×시도에 대해 신뢰수준 $95 \%$ 에서 목표오차 수준 $=5 \%$ 기준)

\section{라. 표본배분방법론 검토}

적정 표본배분방법 도출 및 표본수 산출을 위해 3 가지 주요 표본추출방법론을 활 용하여 상대허용오차수준별 시뮬레이션을 수행하였다.20) 필요 표본수는 전수조사 사업체의 응답률을 $90 \%$ 로 가정하여 산출하였다.

20) 수정절사법은 비례배분법 대비 약 10 배 가량의 표본수가 산출되어 결과 설명에서는 제외하였다. 
[그림 4-10] (중분류×규모×지역)별 상대오차수준(\%)에 따른 필요 표본수

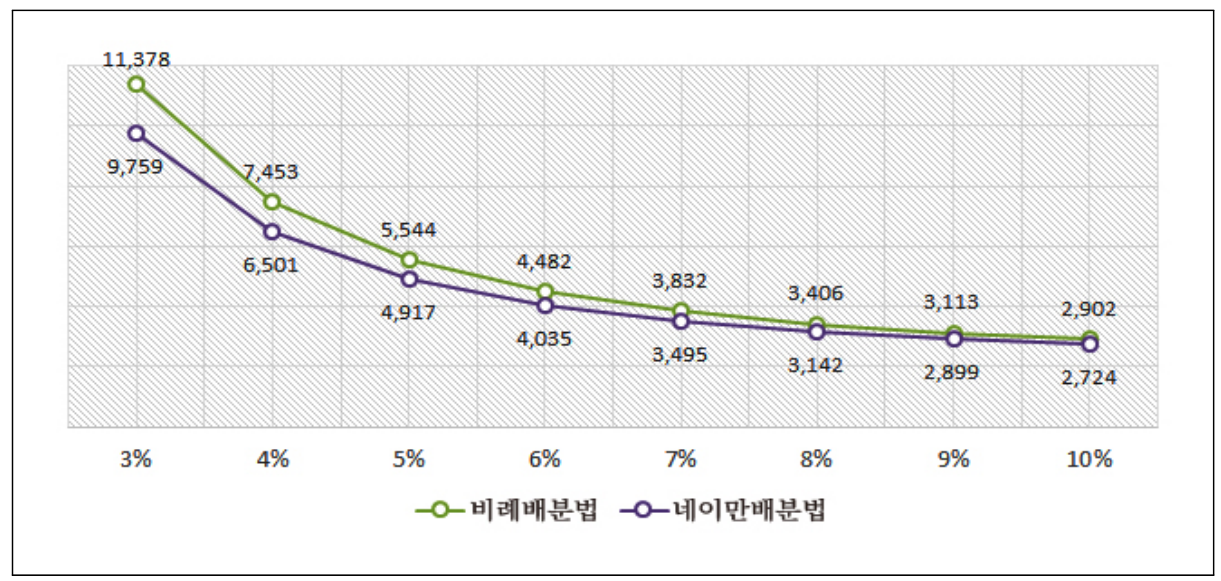

층화기준이 세부화되면 세분화될수록 전체 필요 표본수21)가 증가하는 경향을 나 타낸다(해당 층을 집계하기 위해 최소한의 표본이 필요하게 되며 이에 따라 강제할 당 표본이 증가하게 된다). 모집단 분석으로부터 부차모집단별로 변동이 매우 달라 비례배분법 보다 네이만배분법이 효율적인 방법이다. 반면, 조사설계 시점의 모집 단에 대한 충분한 정보의 확보가 어려울 가능성이 높아 보수적인 비례배분법으로 표본수를 산출하는 것이 적절할 수 있다.

수정절사법의 경우에는 치우침이 매우 심한 부차모집단에 대해서는 다른 표본추 출방법 대비 우수하였으나 전체적으로 과다한 필요 표본을 요구하고 있다. 종사자 수 대신 실제 매출액을 적용한다면 보다 효율적인 결과 도출이 예상된다. (중분류× 규모×지역)의 부차모집단에 대해 네이만배분법과 비례배분법을 활용하여 상대오차 수준에 따른 필요 표본수를 산출하였다. 신뢰수준 95\%에서 상대오차수준이 $\pm 5.0 \% \mathrm{p}$ 인 경우 네이만배분법에 의한 필요 표본수는 약 4,917개, 비례배분법은 5,544개가 도출되었다. ${ }^{22)}$

21) 각 확대전략별 전수조사 대상을 설정하고 표본층에 대한 적정 표본수를 산출하여 전수조사 대상 사업체수 와 합산한 결과임

22) 전수조사 사업체의 응답률은 $90 \%$ 로 가정한 표본수이며, 응답률에 따라 오차는 증가하게 됨 


\section{4. 확대전략별 적정 표본수}

중분류 산업과 규모구분(50인 기준)에 따라 17 개 광역자치단체로 층화 후 신뢰수 준 $95 \%$ 에서 목표 허용오차수준을 $1 \%$ 부터 $1 \%$ 씩 늘리면서 배분법에 따라 필요표본 수를 산출하였다.23)

\section{가. 네이만배분법의 적정 표본수}

〈표 4-28〉 네이만배분법에 의한 적정 표본수 산정 결과

\begin{tabular}{c|c|c|c|c}
\hline \multirow{2}{*}{\begin{tabular}{c} 
상대오차 $\begin{array}{c}|c| \\
\text { 수준 }\end{array}$ \\
\cline { 2 - 5 }
\end{tabular}} & $\begin{array}{c}\text { 핵심 산업 } \\
\begin{array}{c}\text { 학계 } \\
\text { 관광산업의 } \\
\text { a'코드 }\end{array}\end{array}$ & $\begin{array}{c}\text { 2단계 } \\
\text { 핵심관광산업 전체 }\end{array}$ & $\begin{array}{c}\text { 3단계 } \\
\text { 품목분석의 관광산업 } \\
\text { 구분 }\end{array}$ & $\begin{array}{c}\text { 4단계 } \\
\text { 관광특수분류 전체 }\end{array}$ \\
\hline $1 \%$ & 35,454 & 45,693 & 41,605 & 43,999 \\
\hline $2 \%$ & 15,733 & 17,984 & 15,357 & 15,431 \\
\hline $3 \%$ & 8,601 & 9,759 & 8,983 & 9,879 \\
\hline $4 \%$ & 5,576 & 6,501 & 6,604 & 7,915 \\
\hline $5 \%$ & 4,060 & 4,917 & 5,474 & 7,003 \\
\hline $6 \%$ & 3,204 & 4,035 & 4,853 & 6,506 \\
\hline $7 \%$ & 2,675 & 3,495 & 4,476 & 6,206 \\
\hline $8 \%$ & 2,327 & 3,142 & 4,230 & 6,011 \\
\hline $9 \%$ & 2,086 & 2,899 & 4,061 & 5,878 \\
\hline $10 \%$ & 1,912 & 2,724 & 3,940 & 5,782 \\
\hline
\end{tabular}

신뢰수준 $95 \%$ 에서 목표허용오차수준을 $\pm 5 \% \mathrm{p}$ 를 기준으로 1 단계(핵심관광산업 의 ' $\mathrm{a}$ '코드) 사업체는 4,060개소, 2 단계(핵심 관광산업 전체)는 4,917개소, 3 단계 (품목분석의 관광산업 구분) 사업체는 5,474개소, 44단계(관광특수분류 전체) 사업 체는 7,003 개소가 요구되는 것으로 산출되었다.

23) 산출된 표본수는 전수조사층의 사업체는 모두 응답하는 것을 기준으로 산출된 것임 
[그림 4-11] 확대전략별 상대오차수준(\%)에 따른 필요 표본수

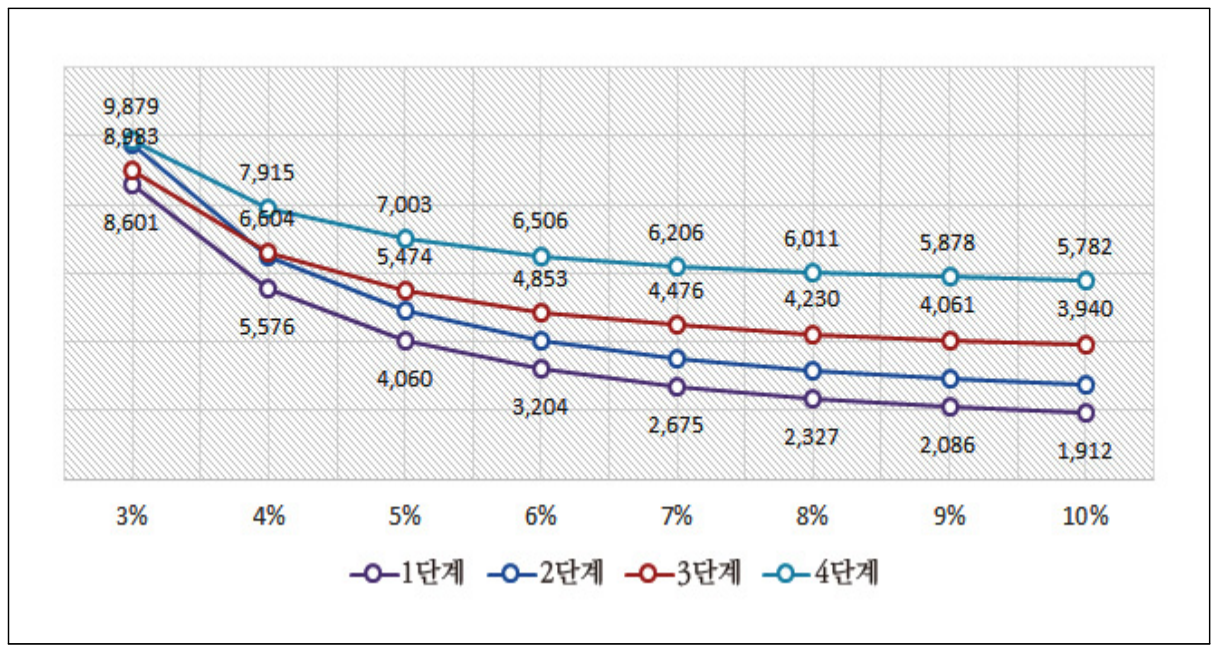

\section{나. 비례배분법의 적정 표본수}

〈표 4-29〉 비례배분법에 의한 적정 표본수 산정 결과

\begin{tabular}{c|c|c|c|c}
\hline \multirow{2}{*}{$\begin{array}{c}\text { 상대오차 } \\
\text { 수준 }\end{array}$} & \multicolumn{2}{|c|}{ 핵심 산업 } & \multicolumn{2}{c}{ 전체 산업 } \\
\cline { 2 - 5 } & $\begin{array}{c}\text { 1닥김곈광산업의 } \\
\text { 'a'코드 }\end{array}$ & 핵심관광산업 전체 & $\begin{array}{c}\text { 3단계 } \\
\text { 품목분석의 관광산업 } \\
\text { 구분 }\end{array}$ & $\begin{array}{c}\text { 4단계 } \\
\text { 관광특수분류 전체 }\end{array}$ \\
\hline $1 \%$ & 39,944 & 54,674 & 64,571 & 58,392 \\
\hline $2 \%$ & 17,623 & 21,289 & 22,584 & 18,539 \\
\hline $3 \%$ & 9,552 & 11,378 & 12,389 & 10,789 \\
\hline $4 \%$ & 6,128 & 7,453 & 8,583 & 8,048 \\
\hline $5 \%$ & 4,412 & 5,544 & 6,776 & 6,774 \\
\hline $6 \%$ & 3,443 & 4,482 & 5,782 & 6,081 \\
\hline $7 \%$ & 2,844 & 3,832 & 5,179 & 5,662 \\
\hline $8 \%$ & 2,450 & 3,406 & 4,786 & 5,391 \\
\hline $9 \%$ & 2,177 & 3,113 & 4,515 & 5,204 \\
\hline $10 \%$ & 1,981 & 2,902 & 4,321 & 5,071 \\
\hline
\end{tabular}

114 관광산업특수분류 개정안에 기초한 관광산업통계 생산방안 연구 
신뢰수준 $95 \%$ 에서 목표허용오차수준을 $\pm 5 \% \mathrm{p}$ 를 기준으로 1 단계(핵심관광산업 의 ' $a$ '코드) 사업체는 4,412개소, 2 단계(핵심 관광산업 전체)는 5,544개소, 3 단계 (품목분석의 관광산업 구분) 사업체는 6,776 개소, 4 단계(관광특수분류 전체) 사업 체는 6,774 개소가 요구되는 것으로 산출되었다.

[그림 4-12] 확대전략별 상대오차수준(\%)에 따른 필요 표본수

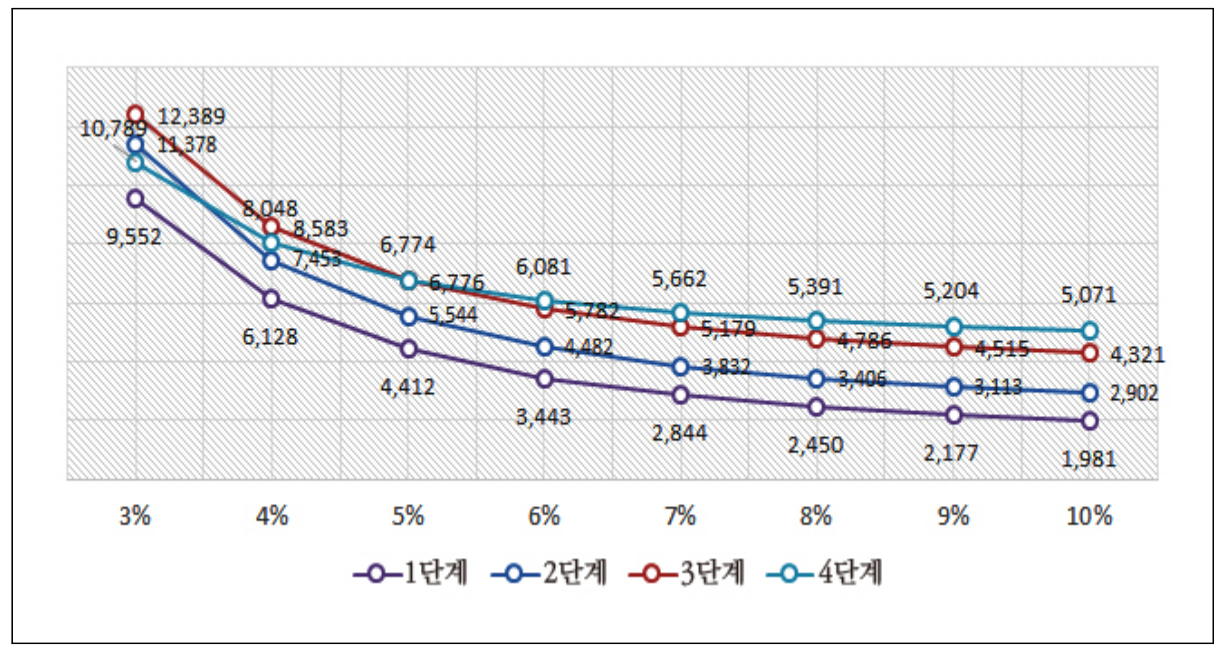




\section{제3절 모수추정방안 제시}

\section{1. 통계적 추정}

본 연구의 주요 추정대상은 총합, 평균, 비율이다. 각 추정대상에 대하여 통계조 사에서 요구되는 모수추정식과 각 추정대상별 표준오차 산출식도 같이 제시하였다.

\section{가. 용어 정의}

각 세부 층별(산업분류x지역×종사자수 규모)에 대한 추출률(Inclusion Probability) 을 고려하여 모집단의 모수에 대한 추정치와 표준오차를 다음과 같이 계산한다. 추정을 위한 주요 용어 및 기호에 대하여 설명한다.

- $y_{h k}$ : 관찰값 (각 항목에 대한 응답)을 나타내며 $y_{h k}$ 는 $h$ 번째 세부 층의 $k$ 번째 표본 사업체에 대한 관찰값을 의미한다.

- $h$ : 세부 층을 나타내는 번호 $(h=1,2, \cdots, L)$

- $k$ : 세부 층의 사업체 번호 $\left(k=1,2, \cdots, n_{h}\right)$

- $n_{h}: h$ 번째 세부 층에 대한 표본크기

- $N_{h}: h$ 번째 세부 층에 대한 모집단 크기

- $n=\sum_{h=1}^{L} n_{h}$ : 전체 표본크기

- $N=\sum_{h=1}^{L} N_{h}$ : 전체 모집단 크기 
- $\bar{y}_{h}=\sum_{k=1}^{n_{h}} \frac{y_{h k}}{n_{h}}: h$ 번째 세부 층의 표본평균

- $\hat{\tau}_{h}=N_{h} \bar{y}_{h}: h$ 번째 세부 층의 표본합

- $s_{h}^{2}=\sum_{k=1}^{n_{h}} \frac{\left(y_{h k}-\bar{y}_{h}\right)^{2}}{\left(n_{h}-1\right)}: h$ 번째 세부 층의 표본분산

- $s_{h}=\sqrt{\sum_{k=1}^{n_{h}} \frac{\left(y_{h k}-\bar{y}_{h}\right)^{2}}{\left(n_{h}-1\right)}}: h$ 번째 세부 층의 표본표준편차

- $\hat{p}_{h}$ : $h$ 번째 세부 층의 표본비율

\section{나. 추정식}

1) 모집단 총계 $\tau$ 의 추정량 및 분산

- 모집단 총계 $\tau$ 의 추정량:

$$
\hat{\tau}=\hat{\tau}_{c}+\hat{\tau}_{s}=\sum_{h=1}^{L} \sum_{k=1}^{n_{h}} y_{h k}+\sum_{h=1}^{L} \sum_{k=1}^{n_{h}} w_{h s} y_{h k}
$$

- 모집단 총계 $\tau$ 의 분산 추정량: $\widehat{\operatorname{Va}}(\hat{\tau})=\sum_{h=1}^{L} N_{h}^{2}\left(\frac{N_{h}-n_{h}}{N_{h}}\right) \frac{s_{h}^{2}}{n_{h}}$

여기서, $\quad c$ : 전수층을 나타내는 첨자

$s$ : 표본층을 나타내는 첨자

\section{2) 모평균 $\mu$ 의 추정량 및 분산}

- 모평균 $\mu$ 의 추정량: $\hat{\mu}=\sum_{h=1}^{L} w_{h} \bar{y}_{h}$

- 모평균 $\mu$ 의 분산 추정량: $\widehat{\operatorname{Var}}(\hat{\mu})=\sum_{h=1}^{L}\left(\frac{N_{h}}{N}\right)^{2}\left(\frac{N_{h}-n_{h}}{N_{h}}\right) \frac{s_{h}^{2}}{n_{h}}$ 


\section{3) 모비율 $p$ 의 추정량 및 분산}

- 모비율 $p$ 의 추정량: $\hat{p}=\sum_{h=1}^{L} w_{h} \hat{p}_{h}$

- 모비율 $p$ 의 분산 추정량: $\widehat{\operatorname{Var}}(\hat{p})=\sum_{h=1}^{L}\left(\frac{N_{h}}{N}\right)^{2}\left(\frac{N_{h}-n_{h}}{N_{h}}\right) \frac{\hat{p}_{h}\left(1-\hat{p}_{h}\right)}{n_{h}-1}$

\section{4) 표준오차 및 오차한계의 추정}

- 표준오차: $\sqrt{\widehat{V a r}}$

- 신뢰수준 $100 \times(1-\alpha) \%$ 의 오차한계: $z_{\alpha / 2} \sqrt{\widehat{\operatorname{Var}}}$

(예: $95 \%$ 신뢰수준의 오차한계 $=1.96 \sqrt{\widehat{V a r}}$ )

\section{2. 가중치}

표본조사 결과를 이용한 모집단 추정을 위해 가중치를 반영하여야 한다. 특히 관 광진흥법의 관광사업체에서 확대되는 조사에서 조사 기본 가중치(설계, 무응답, 사 후) 이외에도 관광산업의 영위여부 및 관광산업 영위 비율(관광비)을 추정하기 위한 가중치를 추가적으로 고려할 필요가 있다.

\section{가. 조사 기본 가중치}

가중치는 설계가중치 $\left(w_{1}\right)$, 무응답 보정 가중치 $\left(w_{2}\right)$, 사후층화 가중치 $\left(w_{3}\right)$ 로 구성된다.

$$
w=w_{1} \times w_{2} \times w_{3}
$$

설계가중치는 업종별, 종사자수 규모별 층화 후 확률비례 계통추출하는 층화계통 추출법을 적용하여 표본을 추출한다. 층별 사업체 추출률의 역수로 설계가중치를 계산, 산업 중분류별 가중치는 아래와 같이 계산한다. 


$$
w_{1, h}=\frac{N_{h}}{n_{h}}
$$

$$
\begin{aligned}
& \text { 여기서, } w \text { : 가중치 (추출률의 역수) } \\
& h \text { : 층을 나타내는 첨자 }
\end{aligned}
$$

무응답 보정 가중치 $m_{h}$ 는 산업중분류별로 다음과 같이 정의한다.

$$
m_{h}=\frac{n_{h}}{R_{h}}
$$

여기서, $\quad R$ : 표본사업체중에서 응답한 사업체수

산업별, 규모별 무응답 보정 가중치는 설계가중치와 보정계수를 곱하여 산출한다.

$$
w_{2, h}=w_{1} \times m_{h}
$$

사후층화 가중치는 표본설계 시 사용한 표본추출틀과 모집단 정보를 기준 으로 하고 조사 결과를 이용하여 갈퀴 비 조정을 통해 모집단 변화를 반영하도록 한다. 사후층화 조정 후의 최종가중치는 다음과 같이 산출한다.

$$
w_{3, h}=\frac{T_{h}}{N_{h}}
$$

여기서 $T_{h}$ 는 산업별 모집단 사업체수이다.

\section{나. 전체 사업체중 관광산업 비(ratio) 가중치}

전체 사업체 중에서 관광산업의 비(ratio)를 적용하기 위한 방안을 고려한다. 산업과 규모의 특성에 따라 관광산업의 분포를 파악하여 분포에 따라 관광산업 비를 추정하기 위한 조사전략을 수립하는 기초자료로 활용하고자 한다. 전체 관광산업을 중분류별로 품목분석으로 식별되는 사업체수와 종사자수의 비중에 대한 현황을 나타내고 있다. 
〈표 4-30〉 관광산업특수분류 중분류별 품목분석 구분 사업체와 종사자수의 비중 현황

\begin{tabular}{|c|c|c|c|c|c|c|c|}
\hline \multirow[b]{2}{*}{ 대분류 } & \multirow[b]{2}{*}{ 중분류 } & \multicolumn{3}{|c|}{ 사업체수 } & \multicolumn{3}{|c|}{ 종사자수 } \\
\hline & & $\begin{array}{l}\text { 관광 } \\
\text { 산업 }\end{array}$ & 비중 & 전체 & $\begin{array}{l}\text { 관광 } \\
\text { 산업 }\end{array}$ & 비중 & 전체 \\
\hline \multirow{9}{*}{$\begin{array}{l}\text { 핵심 } \\
\text { 관광 } \\
\text { 산업 }\end{array}$} & 관광 쇼핑업(도매업 제외) & 1,237 & $83.4 \%$ & 1,483 & 6,453 & $90.7 \%$ & 7,118 \\
\hline & 관광 운수업 & 1,420 & $90.9 \%$ & 1,563 & 59,330 & $91.0 \%$ & 65,176 \\
\hline & 관광 숙박업 & 24,107 & $76.3 \%$ & 31,609 & 109,991 & $81.7 \%$ & 134,639 \\
\hline & 관광 음식점 및 주점업 & 1,468 & $5.9 \%$ & 24,675 & 9,962 & $6.5 \%$ & 152,633 \\
\hline & 여행사 및 여행보조 서비스업 & 6,780 & $67.1 \%$ & 10,099 & 33,066 & $66.3 \%$ & 49,870 \\
\hline & 국제회의업 & 219 & $64.6 \%$ & 339 & 3,559 & $75.5 \%$ & 4,713 \\
\hline & 문화, 오락 및 레저 스푸츠산업 & 7,391 & $93.3 \%$ & 7,921 & 103,278 & $95.6 \%$ & 108,038 \\
\hline & 카지노업a & 16 & $100.0 \%$ & 16 & 8,728 & $100.0 \%$ & 8,728 \\
\hline & 소계 & 42,638 & $54.9 \%$ & 77,705 & 334,367 & $63.0 \%$ & 530,915 \\
\hline \multirow{5}{*}{$\begin{array}{l}\text { 상호 } \\
\text { 의존 } \\
\text { 관광 } \\
\text { 산업 }\end{array}$} & 관광 건설업 & 192 & $7.5 \%$ & 2,557 & 2,684 & $20.2 \%$ & 13,299 \\
\hline & 관광 및 레저용품 소매업 & 3,962 & $16.1 \%$ & 24,630 & 6,374 & $11.9 \%$ & 53,356 \\
\hline & 관광보험및금융서비스업 & 511 & $15.6 \%$ & 3,274 & 1,029 & $1.2 \%$ & 84,178 \\
\hline & 레저장비업 & 4,268 & $95.5 \%$ & 4,467 & 15,347 & $96.4 \%$ & 15,912 \\
\hline & 소계 & 8,933 & $25.6 \%$ & 34,928 & 25,434 & $15.3 \%$ & 166,745 \\
\hline \multirow{7}{*}{$\begin{array}{l}\text { 부분 } \\
\text { 적용 } \\
\text { 관광 } \\
\text { 산업 }\end{array}$} & 관광 비인증 쇼핑업 & 5 & $0.0 \%$ & 116,409 & 22 & $0.0 \%$ & 478,771 \\
\hline & 부분관광 운송업 & 1,138 & $20.7 \%$ & 5,489 & 22,866 & $49.1 \%$ & 46,610 \\
\hline & 부분관광 숙박업 & 15,604 & $85.5 \%$ & 18,246 & 41,285 & $86.6 \%$ & 47,695 \\
\hline & 부분관광 음식점 및 주점업 & 77,393 & $17.8 \%$ & 435,911 & 159,816 & $13.2 \%$ & $1,214,221$ \\
\hline & 부분관광 공연장업 & 337 & $75.1 \%$ & 449 & 1,030 & $16.8 \%$ & 6,136 \\
\hline & 부분관광 기타 서비스업 & 424 & $19.5 \%$ & 2,174 & 6,422 & $31.0 \%$ & 20,688 \\
\hline & 소계 & 94,901 & $16.4 \%$ & 578,678 & 231,441 & $12.8 \%$ & $1,814,121$ \\
\hline \multirow{5}{*}{$\begin{array}{l}\text { 관광 } \\
\text { 지원 } \\
\text { 산업 }\end{array}$} & 관광 연구 개발업 & 26 & $12.8 \%$ & 203 & 847 & $22.4 \%$ & 3,774 \\
\hline & 관광 공공기관 & 193 & $5.6 \%$ & 3,477 & 13,546 & $9.3 \%$ & 146,270 \\
\hline & 관광 교육서비스업 & 155 & $0.6 \%$ & 27,656 & 1,244 & $0.5 \%$ & 267,779 \\
\hline & 관광 단체 & 206 & $100.0 \%$ & 206 & 741 & $100.0 \%$ & 741 \\
\hline & 소계 & 580 & $1.8 \%$ & 31,542 & 16,378 & $3.9 \%$ & 418,564 \\
\hline & 전체 & 147,052 & $20.3 \%$ & 722,853 & 607,620 & $20.7 \%$ & $2,930,345$ \\
\hline
\end{tabular}

품목분석의 관광산업이 구분되는 산업의 비중은 사업체수 기준으로 전체 722,853 개 중에서 147,052 개로 $20.3 \%$ 를 차지한다. 종사자수 기준으로는 전체 $2,930,345$ 명 중에서 607,620 명으로 $20.7 \%$ 를 차지하고 있다.

대분류별로는 사업체수 기준으로 상호의존 관광산업이 $25.6 \%$, 부분적용 관광산 
업이 $16.4 \%$, 관광지원산업이 $1.8 \%$ 를 차지하고 있고 종사자수 기준으로는 상호의 존 관광산업이 $15.3 \%$, 부분적용 관광산업이 $12.8 \%$, 관광지원산업이 $20.7 \%$ 를 차지 하고 있다.

특히, 사업체수가 가장 많은 "부분관광 음식점 및 주점업"의 경우는 사업체수 비 중은 $17.8 \%$, 종사자수 기준은 $13.2 \%$ 가 관광산업으로 식별되고 있다. "관광 비인증 쇼핑업”의 경우는 116,409 개 사업체중에서 5 개만이 식별되고 있다.

전체 1 만개 이상 사업체가 있는 중분류산업에서 관광 교육서비스업은 전체 27,656 개 중에서 155 개만이 관광산업으로 식별되고 있고 관광 및 레저용품 소매업 은 24,630 개 사업체중에서 $16.1 \%$ 가 식별되고 있다. 반면, 부분관광 숙박업은 전체 18,249 개 중에서 $85.5 \%$ 가 관광산업으로 식별되고 있다.

〈표 4-31〉 관광산업 식별 비중에 따른 관광산업특수분류 중분류 현황

\begin{tabular}{|c|c|c|c|c|}
\hline \multirow{2}{*}{$\begin{array}{c}\text { 관광산업 식별 } \\
\text { 비중 }\end{array}$} & \multicolumn{2}{|l|}{ 사업체수 기준 } & \multicolumn{2}{|l|}{ 종사자수 기준 } \\
\hline & 중분류 산업 & 사업체수 & 중분류 산업 & 종사자수 \\
\hline $10 \%$ 미만 & $\begin{array}{l}\text { 관광 비인증 쇼핑업 } \\
\text { 관광 교육서비스업 } \\
\text { 관광 공공기관 } \\
\text { 관광 음식점 및 주점업 } \\
\text { 관광 건설업 }\end{array}$ & 174,774 & $\begin{array}{c}\text { 관광 비인증 쇼핑업 } \\
\text { 관광 교육서비스업 } \\
\text { 관광 공공기관 } \\
\text { 관광 음식점 및 주점업 } \\
\text { 관광 보험 및 금융서비스업 }\end{array}$ & $1,129,631$ \\
\hline $\begin{array}{c}\text { 20\% 20\% } \\
\text { 미만 }\end{array}$ & $\begin{array}{c}\text { 관광 보험 및 금융서비스업 } \\
\text { 관광 및 레저용품 소매업 } \\
\text { 부분관광 음식점 및 주점업 } \\
\text { 부분관광 기타 서비스업 } \\
\text { 관광 연구 개발업 }\end{array}$ & $\begin{array}{l}466,192 \\
(30,281)\end{array}$ & $\begin{array}{c}\text { 관광 및 레저용품 소매업 } \\
\text { 부분관광 음식점 및 주점업 } \\
\text { 부분관광 공연장업 }\end{array}$ & $\begin{array}{c}1,273,713 \\
(59,492)\end{array}$ \\
\hline $\begin{array}{c}20 \% \text { } 50 \% \\
\text { 미만 }\end{array}$ & 부분관광 운송업 & 30,281 & $\begin{array}{c}\text { 관광 연구 개발업 } \\
\text { 부분관광 운송업 } \\
\text { 관광 건설업 } \\
\text { 부분관광 기타 서비스업 }\end{array}$ & 84,371 \\
\hline
\end{tabular}

관광산업 식별비중이 비교적 높은 산업분류에 대해서는 표본조사를 통해 추정한 결과에 “관광산업 비(ratio)”를 곱하여 최종 결과를 추정할 수 있다. 반면, 관광산업 식별비중이 적은 산업분류에 대해서는 추가 조사를 통해 식별비중을 보완하여 추정 에 활용해야 할 것으로 사료된다. 


\section{제4절 관광산업특수분류 기준 설문 설계 및 관광비 추정 방안}

\section{1. 설문 설계}

\section{가. 기존 관광사업체조사 설문 구성 현황}

본 절에서는 기존 관광진흥법상 등록·허가·신고·지정된 사업체를 대상으로 진행 되고 있는 '관광사업체조사(승인번호 제113017호)' 항목을 기초로 하여, 본 연구를 통해 파악된 관광산업특수분류 기준 업종을 포괄할 수 있는 설문항목 구성 방안을 중점적으로 검토하였다.

관광사업체 실태 파악을 위한 대표적인 조사통계인 '관광사업체조사' 설문항목은 크게 조사 대상 모든 업종에 공통으로 포함되는 항목(공통 항목)과 세부 업종별 특 성을 고려한 보다 심층적인 실태 파악을 위한 항목(특수 항목)으로 구분된다. 공통 항목의 경우 사업체 일반 현황, 영업 현황, 고용 현황, 재무 현황, 전자상거래 활용 현황, 자격증 보유 현황 부문으로 구성되어 있다. 특수항목의 경우 세부 업종 특성 에 따라 다양한 설문항목으로 구성되어 있는데 예를 들어 여행업의 경우 이용객 특 성별 여행상품 판매액, 구매자 수 등을 파악하는 문항이 포함되어 있으며, 관광숙박 업의 경우 객실, 부대시시설별 매출액 현황 파악을 위한 문항, 판매객실 수 등의 문 항이 추가 포함되어 있다. 이외 관광객이용시설업, 유원시설업 등의 경우도 각 업종 별 특성을 고려한 세부 비목별 매출액과 이용객 수 파악을 위한 항목과 시설 운영 관련 항목 등이 추가 포함되어 있다. 공통항목, 특수항목별 세부 내용은 다음 〈표 4-32〉, 〈표 4-33〉과 같다. 
〈표 4-32〉 기존 관광사업체조사 설문 항목(공통 항목)

\begin{tabular}{|c|c|c|}
\hline \multicolumn{2}{|r|}{ 구 분 } & 조사 항목 \\
\hline \multirow{5}{*}{$\begin{array}{l}\text { 일반 } \\
\text { 현황 }\end{array}$} & 업종분류 & 업종별 세부분류 \\
\hline & 업종등록현황 & 업종등록 현황 \\
\hline & 사업체 개요 & $\begin{array}{c}\text { 사업체명, 전화번호, 대표자 성별, 소재지, } \\
\text { 인터넷 홈페이지 보유여부, 창설년월, } \\
\text { 사업자등록번호 }\end{array}$ \\
\hline & 조직형태 & 개인사업체, 회사법인, 회사외법인, 비법인단체 \\
\hline & 회계년도 & 회계년도 결산월 \\
\hline \multirow{4}{*}{$\begin{array}{l}\text { 사업체 } \\
\text { 현황 }\end{array}$} & 사업체 구분 & $\begin{array}{c}\text { 단독사업체, 본사(점)/본부/중앙회, } \\
\text { 지역본사(점)/지역본부/지역중앙회, 영업장/지사(점)/출장소 }\end{array}$ \\
\hline & 영업현황 & $\begin{array}{c}\text { 일일 평균영업 시간, 연간 영업개월 수, } \\
\text { 월평균 휴무일 수 }\end{array}$ \\
\hline & 건물 연면적 & 소유 형태별 건물 연면적 \\
\hline & 편의시설 연면적 & 소유 형태별 편의시설 연면적 \\
\hline \multirow{2}{*}{$\begin{array}{l}\text { 고용 } \\
\text { 현황 }\end{array}$} & 종사자 수 & 특성별 종사자 수 \\
\hline & 신규 채용 및 이직 현황 & 연간 신규 채용 종사자 수/이직자 수 \\
\hline \multirow{3}{*}{$\begin{array}{l}\text { 재무 } \\
\text { 현황 }\end{array}$} & 연간 투자비 & 사업체 연간 시설 투자비 \\
\hline & 자본금 & 자본금 \\
\hline & 매출액 & 연간 총 매출액 \\
\hline \multirow{2}{*}{$\begin{array}{c}\text { 전자상거래활용 } \\
\text { 현황 }\end{array}$} & 전자상거래 활용 & 전자상거래 활용 형태 \\
\hline & 전자상거래 실적 & 총 매출액 대비 비중, 총 구매액 대비 비중 \\
\hline $\begin{array}{l}\text { 자격증 } \\
\text { 보유 현황 }\end{array}$ & $\begin{array}{l}\text { 종사원자격증 } \\
\text { 보유현황 }\end{array}$ & $\begin{array}{c}\text { 관광통역안내사, 국내여행 안내사, } \\
\text { 국외여행 인솔자, 호텔경영사, } \\
\text { 호텔관리사, 호텔서비스사, 기타 자격증 }\end{array}$ \\
\hline
\end{tabular}


〈표 4-33〉 기존 관광사업체조사 설문 항목(업종별 특수 항목)

\begin{tabular}{|c|c|c|}
\hline 업종구분 & 항목 구분 & 조사 항목 \\
\hline \multirow{3}{*}{ 여행업 } & 매출액 & $\begin{array}{l}\text { 외국인 대상 국내여행 상품 판매액, } \\
\text { 내국인 대상 해외여행 상품 판매액, } \\
\text { 내국인 대상 국내여행 상품 판매액, } \\
\text { 항공권/선박권 판매 수수료 }\end{array}$ \\
\hline & 연간 이용객 현황 & $\begin{array}{l}\text { 외국인 대상 국내여행 상품 구매자 수, } \\
\text { 내국인 대상 해외여행 상품 구매자 수, } \\
\text { 내국인 대상 국내여행 상품 구매자 수, } \\
\text { 항공권/선박권 구매자 수 }\end{array}$ \\
\hline & $\begin{array}{c}\text { 여행상품(패키지) } \\
\text { 판매 현황 }\end{array}$ & $\begin{array}{l}\text { 외국인 대상 국내여행 상품(상품별 판매 및 매출액 비중) } \\
\text { 내국인 대상 해외여행 상품(상품별 판매 및 매출액 비중) } \\
\text { 내국인 대상 국내여행 상품(상품별 판매 및 매출액 비중) }\end{array}$ \\
\hline \multirow{3}{*}{ 관광숙박업 } & 매출액 & 객실 매출액, 부대시설 매출액 \\
\hline & 객실판매현황 & 이용객 수, 판매객실 수 \\
\hline & 기타 & 객실 현황, 근무 교대 주기 \\
\hline \multirow[b]{3}{*}{$\begin{array}{c}\text { 관광객 } \\
\text { 이용시설업 }\end{array}$} & 매출액 & 메인시설 매출액, 부대시설 매출액, 기타 매출액 \\
\hline & 연간 이용객 수 & 연간 이용객 수 \\
\hline & 시설 및 운영 현황 & $\begin{array}{l}\text { 전문 및 종합휴양업 객실현황, 야영장업 시설현황, } \\
\text { 관광유람선 보유현황(보유 선박수, 보유 선박 총 중량) } \\
\text { 외국인관광 도시민박업: } \\
\text { 객실(BED) 현황, } 1 \text { 인(BED 1개)당 평균 가격, } \\
\text { 연간 객실 판매 현황, 주택 형태 및 주요 운영 형태 } \\
\text { 연간 시설 투자비 및 연간 총 매출액(단위: 십만원) }\end{array}$ \\
\hline \multirow{4}{*}{ 국제회의업 } & 연간 참가자 수 & 내국인 수, 외국인 수 \\
\hline & 최대수용력 & 회의시설(좌석 수), 전시시설(좌석 수) \\
\hline & 사업실적 & $\begin{array}{l}\text { 국제회의시설업: } \\
\text { 연간개최일, 국제/국내행사 개최건수 및 참가업체 수 } \\
\text { 국제회의기획업: } \\
\text { 해외/국내업체 계약건수 및 참가업체 수 }\end{array}$ \\
\hline & 행사주최성격별 개최 현황 & 정부 및 지방자치단체, 공기업/사기업, 각종 이익단체 \\
\hline \multirow{4}{*}{ 카지노업 } & 매출액 & 카지노 매출액, 부대시설 매출액, 기타 매출액 \\
\hline & 연간 이용객 수 & 연간 이용객 수 \\
\hline & 시설 현황 & 테이블 게임, 머신 게임 \\
\hline & 최대수용력 & 테이블 게임, 머신 게임 \\
\hline \multirow{3}{*}{ 유원시설업 } & 매출액 & 입장료, 유기기구, 부대시설, 기타시설 매출액 \\
\hline & 연간 이용객 수 & 연간 이용객 수 \\
\hline & 시설 현황 & 유기시설 수, 안전검사 대상 유기시설 수 \\
\hline \multirow{3}{*}{$\begin{array}{c}\text { 관광 } \\
\text { 편의시설업 }\end{array}$} & 연간 이용객 수 & 연간 이용객 수 \\
\hline & 최대수용력 & 수용 가능 좌석 수 \\
\hline & 시설 및 운영 현황 & $\begin{array}{l}\text { 관광펜션업, 한옥체험업: } \\
\text { 객실 현황, 객실당 평균 가격, 연간 객실 판매 현황 }\end{array}$ \\
\hline
\end{tabular}




\section{나. 업종별 공통 항목 구성 방안}

업종별 공통 항목의 경우 사업체 기본 현황 파악을 위한 항목과 연간 매출액, 종 사자 수 등 사업체 실태 파악을 위한 조사 시 핵심 지표를 대변할 수 있는 항목 중심 으로 구성하고자 한다. 설문 구성 대상 업종은 관광산업특수분류체계 기준 핵심 관 광산업으로 분류된 업종(세분류 단위)으로 설정하였으며, 특히 핵심 관광산업 내 업 종 중 절반 이상(56개 업종 중 30 개 업종)이 관광진흥법상 등록·허가·신고·지정된 업종인 점을 고려하여 동일 업종 대상으로 진행되어 온 관광사업체조사 설문 항목 중 공통 항목을 기본 활용하였다.

공통 항목 중 사업체 기본 현황 파악을 위한 문항에는 업종분류, 업종등록 현황, 소재지, 조직형태 등 사업체 기본 사항 파악을 내용(기존 관광사업체조사 설문 항목 중 일반 현황, 사업체 현황 부문 항목 해당)이 포함된다. 포함 대상 항목 중 소재지 정보의 경우 지역 단위 관광산업 통계 작성 시 정보로 활용할 수 있으며, 조직형태 항목의 경우 조직형태별 관광사업체 경영실적 파악을 통한 우리나라 관광산업의 구 조 변화 파악, 영업시간 및 영업개월 수 등 운영 관련 항목의 경우 영업시간 및 기간 과 사업실적 간의 합리적 판단을 위한 기초자료로써 활용되는 자료로 사업체 실태 조사 시 기본적으로 포함되는 항목이다.

공통 항목 중 연간 매출액, 종사자 수 등 핵심 지표 산출을 위한 항목의 경우 사업 실적(매출액), 종사자 수, 전자상거래 활용 현황 등을 파악할 수 있는 내용(기존 관 광사업체조사 설문 항목 중 고용 현황, 재무 현황, 전자상거래 현황 부문 항목 해당) 을 포함하고자 한다, 사업실적(매출액)과 종사자 수의 경우 업종별 경영실적 파악 및 고용정책 수립을 위한 기초자료로 활용되는 기본 항목이며, 전자상거래 활용 현 황 정보의 경우 관광산업 전체 시장 규모 중 정보기술 기반 매출 비중 파악을 위한 항목이라 할 수 있다. 특히 본 항목은 우리나라 서비스 관련 업종 전수를 대상으로 진행되고 있는 '서비스업조사(승인번호 제101027호)'에서도 숙박업, 음식점 및 주 점업 등 본 조사 대상 업종에 대해 공통 항목으로 포함되어 있는 항목임을 고려하여 본 조사 설문 구성 시에도 동일한 기준을 적용하고자 한다.

이외 기존 관광사업체조사 공통 항목 중 관광 분야 자격증 보유 현황 부문의 경우 본 조사 시에는 업종별 특수 항목으로 이동 배치하고자 한다. 핵심 관광산업 관련 
업종 중 관광진흥법상 등록·허가·신고·지정된 업종의 경우 본 설문을 공통으로 적 용할 수 있지만, 이외 신규 포함된 업종(예: 낚시장 운영업, 자연공원 운영업 등)의 경우 본 문항을 설문하더라도 극히 적은 수만 파악되거나 경우에 따라서는 관광 관 련 자격증 보유자가 존재하지 않을 수 있기 때문이다.

이를 고려한 본 조사 업종별 공통 항목 구성 및 항목별 조사 목적을 정리하면 다 음〈표 4-34〉와 같다.

〈표 4-34〉 관광산업특수분류체계 기준 관광사업체조사 설문 항목(공통 항목) 구성안

\begin{tabular}{|c|c|c|c|}
\hline \multicolumn{2}{|c|}{ 구 분 } & 설문 항목 & 구성 시 주안점 \\
\hline \multirow{5}{*}{$\begin{array}{l}\text { 일반 } \\
\text { 현황 }\end{array}$} & 업종분류 & 업종별 세부분류 & \multirow{3}{*}{$\begin{array}{l}\text { 업종별 사업체 수, } \\
\text { 중복여부 확인 }\end{array}$} \\
\hline & 업종등록현황 & 업종등록 현황 & \\
\hline & 사업체 개요 & $\begin{array}{c}\text { 사업체명, 전화번호, 창설년월, } \\
\text { 사업자등록번호 등 }\end{array}$ & \\
\hline & 조직형태 & $\begin{array}{c}\text { 개인사업체, 회사법인, 회사외법인, } \\
\text { 비법인단체 }\end{array}$ & $\begin{array}{c}\text { 형태별 경영실적 파악을 통한 } \\
\text { 관광산업 구조적 } \\
\text { 특성 파악 }\end{array}$ \\
\hline & 회계년도 & 회계년도 결산월 & 사업실적 응답 정확성 고려 \\
\hline \multirow{4}{*}{$\begin{array}{l}\text { 사업체 } \\
\text { 현황 }\end{array}$} & 사업체 구분 & $\begin{array}{c}\text { 단독사업체, 본사(점)/본부/중앙회, } \\
\text { 지역본사(점)/지역본부/지역중앙회, } \\
\text { 영업장/지사(점)/출장소 }\end{array}$ & $\begin{array}{c}\text { 사업체 형태별 } \\
\text { 관광사업체 구조 파악 }\end{array}$ \\
\hline & 영업현황 & $\begin{array}{c}\text { 일일 평균영업 시간, 연간 } \\
\text { 영업개월 수, 월평균 휴무일 수 }\end{array}$ & $\begin{array}{l}\text { 영업시간 및 기간과 } \\
\text { 사업실적 간 합리적 } \\
\text { 판단자료 확보 }\end{array}$ \\
\hline & 건물 연면적 & 소유 형태별 건물 연면적 & \multirow{2}{*}{$\begin{array}{l}\text { 사업체 규모 관련 } \\
\text { 분석지표 작성 }\end{array}$} \\
\hline & 편의시설 연면적 & 소유 형태별 편의시설 연면적 & \\
\hline \multirow{2}{*}{$\begin{array}{l}\text { 고용 } \\
\text { 현황 }\end{array}$} & 종사자 수 & 특성별 종사자 수 & \multirow{2}{*}{$\begin{array}{l}\text { 고용정책 수립을 위한 } \\
\text { 기초자료 확보 }\end{array}$} \\
\hline & $\begin{array}{l}\text { 신규 채용 및 } \\
\text { 이직 현황 }\end{array}$ & 연간 신규 채용 종사자/이직자 수 & \\
\hline \multirow{3}{*}{$\begin{array}{l}\text { 재무 } \\
\text { 현황 }\end{array}$} & 연간 투자비 & 사업체 연간 시설 투자비 & 시설투자규모 파악 \\
\hline & 자본금 & 자본금 & 자본 보유현황 파악 \\
\hline & 매출액 & 연간 총 매출액 & $\begin{array}{l}\text { 경영실적 파악을 통한 } \\
\text { 시장규모 추정 }\end{array}$ \\
\hline \multirow{2}{*}{$\begin{array}{l}\text { 전자상거래활용 } \\
\text { 현황 }\end{array}$} & 전자상거래 활용 & 전자상거래 활용 형태 & \multirow{2}{*}{$\begin{array}{l}\text { 정보기술 기반 및 } \\
\text { 활용 현황 파악 }\end{array}$} \\
\hline & 전자상거래 실적 & $\begin{array}{c}\text { 총 매출액 대비 비중, 총 } \\
\text { 구매액 대비 비중 }\end{array}$ & \\
\hline
\end{tabular}




\section{다. 업종별 특수 항목 구성 방안}

관광산업특수분류체계 기준 조사 대상 업종에는 관광진흥법상 업종 외에도 다양 한 업종이 상당수 존재한다. 물론 앞서 기술한 업종별 공통 항목을 통해서도 주요 지표에 대해서는 파악이 가능하지만, 개별 업종들이 가지고 있는 특성을 고려한 심 층적인 분석에는 한계가 있다. 이를 고려하여 업종별 특성을 고려한 특수 항목을 추가 구성(핵심 관광산업 기준)하고자 하며, 특히 최대한 많은 업종에 대한 항목 구 성 검토를 위해 기존 분류 시 상호의존 관광산업, 부분 관광산업에 포함된 업종이었 으나 전문가 델파이 조사를 통해 핵심 관광산업 이동 배치가 필요할 것으로 파악된 업종(10개)도 항목 구성 대상 업종으로 추가 반영하였다.

우선 핵심 관광산업 업종을 관광진흥법상 등록·허가·신고·지정된 업종과 그렇지 않은 업종으로 구분하여 현황을 파악하였다(표4-35, 4-36). 수십 개에 이르는 핵심 관광산업 업종 중 특수항목 구성이 필요한 업종은 결국 관광진흥법상 등록·허가·신 고·지정된 업종(기존 진행되어 온 '관광사업체조사'를 통해 업종별 특수 항목이 이 미 구성되어 있음) 이외의 업종이라 할 수 있으며, 그렇다면 관련 업종은 무엇인지, 업종별 특성은 어떠한지 등에 대해 명확히 파악할 필요가 있기 때문이다. 특히 보다 효율적으로 항목 구성 방향을 설정하기 위해 최종 파악된 특수 항목 구성 대상 업종 들을 유사한 분야별로 한 번 더 분류하여 현황을 살펴보았다.

〈표 4-35〉핵심 관광산업 업종 중 관광진흥법상 등록-허가-신고·지정 업종 현황

\begin{tabular}{c|c|c|c}
\hline \multicolumn{2}{|c}{ 업종명(세분류) } \\
\hline \multirow{2}{*}{ 시내순환 관광업 } & 휴양콘도미니엄업 & $\begin{array}{c}\text { 외국인전용 } \\
\text { 유흥음식점업 }\end{array}$ & 관광공연장업 \\
\hline 관광궤도업 & 관광펜션업 & 일반 여행업 & 외국인 전용 카지노업 \\
\hline 관광 유람선업 & 외국인 관광 도시민박업 & 국외 여행업 & 내국인 전용 카지노업 \\
\hline 크루즈업 & 자동차 야영장업 & 국내 여행업 & 소형호텔업 \\
\hline 관광 호텔ㄹ업 & 한옥체험업 & 국제회의 기획업 & 의료관광호텔업 \\
\hline 수상관광 호텔업 & 관광식당업 & 국제회의 시설업 & 일반야영장업 \\
\hline 한국전통 호텔업 & 관광 유흥음식점업 & 종합유원시설업 & 관광사진업 \\
\hline 가족 호ㅌㅔㅔㄹ업 & 관광 극장 유흥업 & 일반유원시설업 & 전문휴양업 \\
\hline 호스텔업 & 관광 공연장업 & 기타유원시설업 & 종합휴양업 \\
\hline
\end{tabular}


〈표 4-36〉 핵심 관광산업 업종 중 관광진흥법상 등록·허가·신고·지정되지 않은 업종 현황

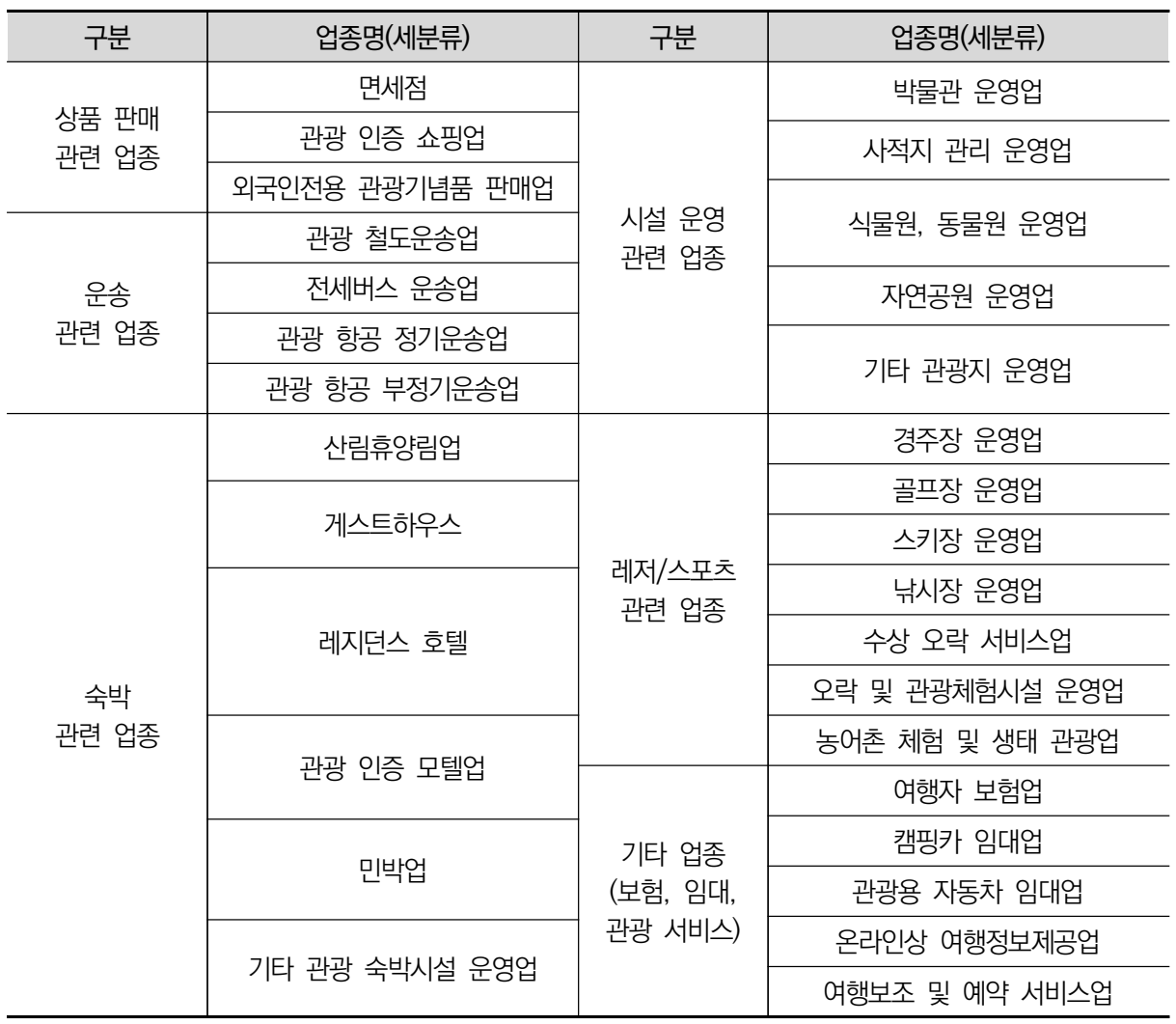

\section{1) 상품 판매 관련 업종}

특수 항목 구성 검토가 필요한 첫 번째 업종 유형은 상품 판매와 관련된 관광 산 업을 영위하는 업종이다. 면세점, 관광 인증 쇼핑업, 외국인전용 관광기념품 판매업 이 해당되며, 취급 품목, 취급 품목별 제조국, 판매 상품 조달 방법, 온라인상 홍보 및 판매 여부, 고객과 거래 시 주요 거래수단, 판매 촉진 방법 등 상품 판매 세부 실적 파악에 주안점을 둔 항목 구성이 필요할 것으로 여겨진다, 아울러 업종별 공통 항목으로 포함되어 있는 총 이용객 수 항목 또한 내/외국인별로 세부 파악하도록 구성할 경우 보다 심층적인 운영 실태 파악이 가능하다. 이외 해당 업종들의 경우 최근 코로나19 사태로 인해 타 업종 대비 상대적으로 큰 타격을 입은 상황인 만큼 향후 필요로 하는 지원 정책 수요에 대한 설문도 추가 포함될 경우 현장상황을 점검 하는 데 많은 도움이 될 것으로 여겨진다. 


\section{2) 운송 관련 업종}

관광객 운송과 관련된 업종으로는 관광 철도운송업, 전세버스 운송업, 관광 항공 정기/비정기운송업이 해당된다. 운송 사업을 영위하는 사업체에 대한 특수 항목으 로는 무엇보다 활용되고 있는 운송수단 현황에 대한 보다 구체적인 파악이 필요하 다. 예를 들어 항공 정기/비정기운송업의 경우 보유하고 있는 여객기 대수, 전세버 스업 운송업의 경우 보유하고 있는 버스 대수 파악이 가능한 설문이 포함되어야 할 것이다. 또한 월간 단위 또는 반기 단위로 평균 관광객 운송 현황을 파악할 수 있는 항목도 이용객 현황을 보다 심층적으로 파악할 수 있는 항목이 될 수 있을 것으로 여겨진다. 관련 항목으로는 구간별 계약 형태(왕복계약/편도계약), 운송거리, 1 회 편도 운송비용, 1 회 편도 운송시간 등이 해당된다.

\section{3) 숙박 관련 업종}

숙박과 관련된 업종으로는 게스트하우스, 레지던스 호텔, 관광 인증 모텔업 등이 포함된다. 이 업종들의 경우 비록 관광진흥법상 등록·허가·신고·지정된 업종은 아 니지만, 주된 사업 활동이 숙박 서비스 제공이라는 점에서 관광진흥법상 관광숙박 업종과 유사한 특성을 지닌다고 할 수 있다. 즉, 기존 관광사업체조사 시 관광숙박 업종에 해당되는 특수 항목을 적용하더라도 이질적이지 않으며, 특히 관광진흥법상 관광숙박업종과 비교 분석이 가능하다는 장점도 있기 때문에 기존 관광진흥법상 관 광숙박업종 특수 항목을 기본 적용하고자 한다. 관련 항목으로는 객실/부대시설별 연간 총 매출액, 판매 객실 수, 객실 현황, 근무 교대 주기 항목 등이 해당된다.

\section{4) 시설 운영 관련 업종}

특정 시설 운영을 통해 관광사업을 영위하고 있는 업종으로는 박물관 운영업, 사 적지 관리 운영업, 자연공원 운영업 등이 있다. 본 업종에 포함되는 사업체들에 대 한 특수 항목의 경우 보유하고 있는 관광 관련 시설 운영 실태 파악에 중점을 두고 구성되어야 한다고 여겨진다. 구체적으로 어떤 시설을 보유하고 있는지, 그 시설 내 관광객들에게 제공되는 자료는 무엇이며 어떤 형태로 제공되는 지 등에 대한 설문 이 관련 항목이 될 것이다. 예를 들어 박물관 운영업의 경우 소장유물 수 및 종류, 
지정(등록) 문화재 수 등이 해당될 것이며, 식물원/동물원 운영업의 경우 소장하고 있는 동/식물 종류 및 개수, 지정(등록) 동/식물 수 등이 해당된다. 또한 소장하고 있는 자료 제공(전시) 형태의 경우 기획/특별전 개최 횟수, 강좌/체험 프로그램 개 최 종류 및 횟수와 관련된 설문을 통해 파악할 수 있을 것으로 여겨진다.

\section{5) 레저/스포츠 관련 업종}

특정 시설 운영을 통해 관광사업을 영위하고 있는 업종 중 특히 레저/스포츠와 관련된 업종도 핵심 관광산업 업종 중 포함되어 있다. 관련 업종으로는 골프장 운영 업, 스키장 운영업, 수상 오락 서비스업 등이 있으며, 가장 특이할만한 점은 대부분 업종이 회원제 운영 방식을 활용하고 있다는 점이다. 즉, 연간 총 매출액이나 이용 객 수 등 공통 항목으로 분류된 항목들을 회원, 비회원별로 세분화하여 볼 수 있도 록 구성할 경우 보다 구체적인 실태 파악이 가능한 만큼 이 부분에 주안점을 두고 항목을 구성하고자 한다. 기본적으로 사업 운영에 있어 회원/비회원 비율이 우선 파악되어야 할 것이며, 이외 회원/비회원별 이용객 수, 회원 기준 이용료, 비회원제 일 경우 이용료 등에 대한 항목이 추가 포함될 수 있을 것으로 여겨진다. 또한 레저 /스포츠 관련 부문의 경우 이용객들의 안전 관리 또한 핵심 이슈가 될 수 있는 만큼 이용객 대상 안전교육 실시 현황, 안전교육 인력 현황, 시설 안전점검 주기 등에 대 한 항목도 추가가 필요할 것으로 판단된다.

\section{6) 기타 업종}

이외 특수항목 검토가 필요한 업종으로는 여행자 보험업, 캠핑카 임대업, 온라인 상 여행정보제공업 등이 있다. 이 중 여행자 보험업, 온라인상 여행정보제공업 등 여행사업과 관련된 업종의 경우 기존 관광진흥법상 여행업종과, 캠핑카/관광용 자 동차 임대업의 경우 관광진흥법상 관광객이용시설업종과 상당 부분 유사한 특성을 지니고 있는 만큼 관련된 특수 항목을 활용하고자 한다. 지금까지 살펴본 핵심 관광 산업 업종 대상 특수 항목 구성안을 정리하면 다음 〈표 4-37〉, 〈표 4-38〉과 같다. 
〈표 4-37〉 관광산업특수분류체계 기준 관광사업체조사 설문 항목(업종별 특수 항목) 구성안 (1)

\begin{tabular}{|c|c|c|}
\hline 구분 & 업종명(세분류) & 조사 항목 \\
\hline \multirow{35}{*}{$\begin{array}{l}\text { 관광 } \\
\text { 진흥법상 } \\
\text { 포함 업종 }\end{array}$} & 일반 여행업 & \multirow{3}{*}{$\begin{array}{l}\text { 세부 상품 유형별 매출액 } \\
\text { 세부 상품 유형별 구매자 수 } \\
\text { 패키지상품 판매 및 매출액 비중 }\end{array}$} \\
\hline & 국외 여행업 & \\
\hline & 국내 여행업 & \\
\hline & 관광 호텔업 & \multirow{8}{*}{$\begin{array}{l}\text { 내외국인별 객실/부대시설 매출액 } \\
\text { 내외국인별 이용객/판매객실 수 } \\
\text { 객실 현황, 근무 교대 주기 }\end{array}$} \\
\hline & 수상관광 호텔업 & \\
\hline & 한국전통 호텔업 & \\
\hline & 가족 호텔업 & \\
\hline & 호스텔업 & \\
\hline & 소형호텔업 & \\
\hline & 의료관광호텔업 & \\
\hline & 크루즈업 & \\
\hline & 휴양콘도미니엄업 & $\begin{array}{l}\text { 회원/비회원별 객실/부대시설 매출액 } \\
\text { 회원/비회원별 이용객/판매객실 수 } \\
\text { 객실 현황, 근무 교대 주기 }\end{array}$ \\
\hline & 종합휴양업 & \multirow{2}{*}{ 세부 유형별 매출액, 연간 이용객 수, 객실현황 } \\
\hline & 전문휴양업 & \\
\hline & 일반야영장업 & 세부 유형별 매출액, 연간 이용객 수, 시설 유형별 보유 현황 \\
\hline & 관광 유람선업 & 세부 유형별 매출액, 연간 이용객 수, 선박 보유 현황 \\
\hline & 자동차 야영장업 & 세부 유형별 매출액, 연간 이용객 수, 시설 유형별 보유 현황 \\
\hline & 관광공연장업 & 세부 유형별 매출액, 연간 이용객 수 \\
\hline & 외국인 관광 도시민박업 & $\begin{array}{l}\text { 객실 현황, BED당 평균 가격, } \\
\text { 연간 객실 판매 현황, 주택 형태 및 주요 운영 형태 }\end{array}$ \\
\hline & 국제회의 기획업 & 해외/국내업체 계약건수 및 참가업체 수 \\
\hline & 국제회의 시설업 & $\begin{array}{l}\text { 내외국인별 연간 참가자 수 } \\
\text { 회의시설(좌석 수), 전시시설(좌석 수) } \\
\text { 연간개최일, 국제/국내행사 개최건수 및 참가업체 수 }\end{array}$ \\
\hline & 외국인 전용 카지노업 & \multirow{2}{*}{ 세부 유형별 매출액, 연간 이용객 수, 시설현황, 최대 수용력 } \\
\hline & 내국인 전용 카지노업 & \\
\hline & 종합유원시설업 & \multirow{3}{*}{$\begin{array}{l}\text { 세부 유형별 매출액, 연간 이용객 수 } \\
\text { 유기시설 수, 안전검사 대상 유기시설 수 }\end{array}$} \\
\hline & 일반유원시설업 & \\
\hline & 기타유원시설업 & \\
\hline & 관광 유흥음식점업 & 연간 이용객 수, 수용 가능 좌석 수 \\
\hline & 관광 극장 유흥업 & 연간 이용객 수, 수용 가능 좌석 수 \\
\hline & 외국인전용 유흥음식점업 & 연간 이용객 수, 수용 가능 좌석 수 \\
\hline & 관광식당업 & 연간 이용객 수, 수용 가능 좌석 수 \\
\hline & 시내순환 관광업 & 연간 이용객 수, 수용 가능 좌석 수 \\
\hline & 관광사진업 & 연간 이용객 수 \\
\hline & 관광궤도업 & 연간 이용객 수 \\
\hline & 관광펜션업 & \multirow{2}{*}{$\begin{array}{l}\text { 연간 이용객 수, 객실 현황, 객실당 평균 가격, } \\
\text { 연간 객실 판매 현황 }\end{array}$} \\
\hline & 한옥체험업 & \\
\hline
\end{tabular}


〈표 4-38〉 관광산업특수분류체계 기준 관광사업체조사 설문 항목(업종별 특수 항목) 구성안 (2)

\begin{tabular}{|c|c|c|}
\hline 구분 & 업종명(세분류) & 조사 항목 \\
\hline \multirow{30}{*}{$\begin{array}{l}\text { 관광 } \\
\text { 진흥법상 } \\
\text { 비포함 업종 }\end{array}$} & 면세점 & \multirow{3}{*}{$\begin{array}{l}\text { 취급 품목, 취급 품목별 제조국, 판매 상품 } \\
\text { 조달 방법, 온라인상 홍보 및 판매 여부, 고객과 거래 } \\
\text { 시 주요 거래수단, 판매 촉진 방법, } \\
\text { 관광사업 운영 관련 지원정책 수요 }\end{array}$} \\
\hline & 관광 인증 쇼핑업 & \\
\hline & 외국인전용 관광기념품 판매업 & \\
\hline & 관광 철도운송업 & \multirow{4}{*}{$\begin{array}{l}\text { 보유 장비 수, 운송구간별 계약 형태(왕복계약/편도계 } \\
\text { 약), 운송거리, } 1 \text { 회 편도 운송비용, } \\
1 \text { 회 편도 운송시간 }\end{array}$} \\
\hline & 전세버스 운송업 & \\
\hline & 관광 항공 정기운송업 & \\
\hline & 관광 항공 부정기운송업 & \\
\hline & 산림휴양림업 & \multirow{6}{*}{$\begin{array}{l}\text { 내외국인별 객실/부대시설 매출액 } \\
\text { 내외국인별 이용객/판매객실 수 } \\
\text { 객실 현황, 근무 교대 주기 }\end{array}$} \\
\hline & 게스트하우스 & \\
\hline & 레지던스 호텔 & \\
\hline & 관광 인증 모텔업 & \\
\hline & 민박업 & \\
\hline & 기타 관광 숙박시설 운영업 & \\
\hline & 박물관 운영업 & \multirow{5}{*}{$\begin{array}{l}\text { 소장 자료 수 및 종류, 지정(등록) 문화재 수, } \\
\text { 기획/특별전 개최 횟수, 강좌/체험 프로그램 } \\
\text { 개최 종류 및 횟수 }\end{array}$} \\
\hline & 사적지 관리 운영업 & \\
\hline & 식물원, 동물원 운영업 & \\
\hline & 자연공원 운영업 & \\
\hline & 기타 관광지 운영업 & \\
\hline & 경주장 운영업 & \multirow{7}{*}{$\begin{array}{l}\text { 회원/비회원별 매출액, 이용객 수 } \\
\text { 회원/비회원 기준 이용료, } \\
\text { 이용객 대상 안전교육 실시 현황, } \\
\text { 안전 교육 인력 현황, 시설 안전점검 주기 }\end{array}$} \\
\hline & 골프장 운영업 & \\
\hline & 스키장 운영업 & \\
\hline & 낚시장 운영업 & \\
\hline & 수상 오락 서비스업 & \\
\hline & 오락 및 관광체험시설 운영업 & \\
\hline & 농어촌 체험 및 생태 관광업 & \\
\hline & 여행자 보험업 & $\begin{array}{l}\text { 세부 상품 유형별 매출액 } \\
\text { 세부 상품 유형별 구매자 수 }\end{array}$ \\
\hline & 캠핑카 임대업 & 연간 이용객 수, 캠핑카 보유 현황 \\
\hline & 관광용 자동차 임대업 & 연간 이용객 수, 자동차 보유 현황 \\
\hline & 온라인상 여행정보제공업 & \multirow{2}{*}{$\begin{array}{l}\text { 세부 상품 유형별 매출액 } \\
\text { 세부 상품 유형별 이용자 수 }\end{array}$} \\
\hline & 여행보조 및 예약 서비스업 & \\
\hline
\end{tabular}




\section{2. 관광비(Tourism Ratio) 추정 방안}

\section{가. 업종간 관광비 산출 방안(업종 분류 간 중복 데이터 보정)}

관광사업체조사 시 정확하고 신뢰성 높은 결과값 산출을 위해 반드시 고려되어야 첫 번째 사안은 복수 업종에 등록된 관광사업체들에 대한 관리이다. 예를 들어 관광 산업특수분류체계 기준 업종 2 개를 등록하고 사업활동을 하고 있는 사업체를 조사 할 때 개별 업종 단위 조사(업종별 분리조사)가 이루어지지 않고, 2 개 업종 실적을 합산하여 조사가 되었을 경우 이는 동일한 값이 각 업종별로 2 번 집계되는 것을 의 미하며, 시장 규모 추정 시 심각한 오류의 원인(과다추정)으로 작용될 수 있다.

복수 업종 등록은 정의상 관광산업에 '전적으로' 의존하는 산업이라 할 수 있는 핵심 관광산업 업종 내에서도 빈번히 확인되는 사안(표 4-39)이며, 만약 부분적용 관광산업, 관광지원산업까지 범위를 넓힐 경우 1 개 사업체의 중복 업종 등록 빈도 수는 더욱 많아질 것으로 여겨진다. 특히 복수 업종 등록 형태는 관광산업특수분류 체계 기준 업종을 2 개 이상 중복 등록하는 형태 뿐 만 아니라 관광산업특수분류체 계 이외 업종을 중복 등록한 경우도 상당수 존재하기 때문에 이러한 사업체 조사 시 관광산업특수분류체계 기준 개별 업종단위 응답값을 확보하기 위한 구체적 방안 이 반드시 마련되어야 한다.

〈표 4-39〉 핵심 관광산업 업종 중 관광진흥법상 포함 업종간 중복등록 사업체 수

\begin{tabular}{c|c|c|c|c|c|c|c}
\hline 구분 & 여행업 & $\begin{array}{c}\text { 관광 } \\
\text { 숙박업 }\end{array}$ & $\begin{array}{c}\text { 관광객 } \\
\text { 이용 } \\
\text { 시설업 }\end{array}$ & $\begin{array}{c}\text { 국제 } \\
\text { 회의업 }\end{array}$ & $\begin{array}{c}\text { 카지 } \\
\text { 노업 }\end{array}$ & $\begin{array}{c}\text { 유원 } \\
\text { 시설업 }\end{array}$ & $\begin{array}{c}\text { 관광 } \\
\text { 년의 } \\
\text { 시설업 }\end{array}$ \\
\hline 여행업 & - & 2 20개 & 4개 & 55개 & 0개 & 0개 & 6개 \\
\hline 관광숙박업 & 20 개 & - & 24개 & 2개 & 3개 & 42개 & 62 개 \\
\hline 관광객이용시설업 & 4개 & 24개 & - & 1개 & 2개 & 34개 & 12 개 \\
\hline 국제회의업 & 55개 & 0개 & 0개 & - & 1개 & 0개 & 0개 \\
\hline 카지노업 & 0개 & 3개 & 2개 & 1개 & - & 2개 & 0개 \\
\hline 유원시설업 & 0개 & 42개 & 34개 & 1개 & 2개 & - & 16개 \\
\hline 관광편의시설업 & 6개 & 62개 & 12개 & 0개 & 0개 & 16개 & - \\
\hline
\end{tabular}


기존 관광사업체조사 시에도 복수 업종 등록 사업체의 응답값 분리, 이른바 업종 간 관광비 추정을 위한 많은 노력이 조사 단계별로 이루어졌으며, 설문 구성 단계에 서도 개별 업종 단위 정확한 응답을 끌어내고자 [그림 4-16]과 같은 형태의 항목을 반영하였다.

[그림 4-13] 관광사업체조사 시 업종 중복 등록 현황 및 매출액 비중 파악 관련 항목

2-1. 업종중복등록 현황 및 등록업종별 매출액 비중 (2019. 12. 31. 기준)

\begin{tabular}{|c|c|c|c|c|c|c|c|}
\hline \multirow[b]{2}{*}{ 가. 업종 대분류 } & \multirow[b]{2}{*}{ 나. 업종 중분류 } & \multirow{2}{*}{\multicolumn{4}{|c|}{ 다. 매출액 비중 }} & \multicolumn{2}{|l|}{ 조사원 기입란 } \\
\hline & & & & & & 통합 조사된 사업체 표본번호 & $\begin{array}{l}\text { 명부 내 } \\
\text { 미화이 }\end{array}$ \\
\hline \multirow{3}{*}{ (1) 여행업 $\square$} & (1) 일반여행업 & & & & $\%$ & & $\square$ \\
\hline & (2) 국외여행업 & & & & $\%$ & & $\square$ \\
\hline & (3) 국내여행업 & & & & $\%$ & & $\square$ \\
\hline \multirow{2}{*}{ (2) 관광숙박업 $\square$} & (1) 호텔업 & & & & $\%$ & & $\square$ \\
\hline & (2) 흥얍콘도미너엄업 & & & & $\%$ & & $\square$ \\
\hline \multirow{7}{*}{ (3) 관광객이용시설업 $\square$} & (1) 전문휴양업 & & & & $\%$ & & $\square$ \\
\hline & (2) 종함휴양업 & & & & $\%$ & & $\square$ \\
\hline & (3) 일반야영장업 & & & & $\%$ & & $\square$ \\
\hline & (4) 자동차야영장업 & & & & $\%$ & & $\square$ \\
\hline & (5) 관광유람선업 & & & & $\%$ & & $\square$ \\
\hline & (6) 관광공연장업 & & & & $\%$ & & $\square$ \\
\hline & (7) 외국인관광 도시민박업 & & & & $\%$ & & $\square$ \\
\hline \multirow{2}{*}{ (4) 국제회의업 $\square$} & (1) 국제회의시설업 & & & & $\%$ & & $\square$ \\
\hline & (2) 국제회의기획업 & & & & $\%$ & & $\square$ \\
\hline \multirow{3}{*}{ (5) 유원시설업 $\square$} & (1) 종합유원시설업 & & & & $\%$ & & $\square$ \\
\hline & (2) 일반유원시설업 & & & & $\%$ & & $\square$ \\
\hline & (3) 기타유원시설업 & & & & $\%$ & & $\square$ \\
\hline \multirow{12}{*}{ (6) 관광편의시설업 $\square$} & (1) 관광유흥음식점업 & & & & $\%$ & & $\square$ \\
\hline & (2) 관광극장유흥업 & & & & $\%$ & & $\square$ \\
\hline & (3) 외국인전용 유흥음식점업 & & & & $\%$ & & $\square$ \\
\hline & (4) 관광식당업 & & & & $\%$ & & $\square$ \\
\hline & (5) 관광순환버스업 & & & & $\%$ & & $\square$ \\
\hline & (6) 관광사진업 & & & & $\%$ & & $\square$ \\
\hline & (7) 여객지동차 터미널시설언 & & & & $\%$ & & $\square$ \\
\hline & (8) 관광펜션업 & & & & $\%$ & & $\square$ \\
\hline & (9) 관광궤도업 & & & & $\%$ & & $\square$ \\
\hline & (10) 한옥체험업 & & & & $\%$ & & $\square$ \\
\hline & (11) 관광면세업 & & & & $\%$ & & $\square$ \\
\hline & (12) 관광지원서비스업 & & & & $\%$ & & $\square$ \\
\hline (7) 카지노업 $\square$ & & & & & $\%$ & & $\square$ \\
\hline \multicolumn{2}{|l|}{ (8) 기타 $\square$ (적어주세요 : } & & & & $\%$ & \multirow{2}{*}{\multicolumn{2}{|c|}{$\begin{array}{r}※ \text { 기타 : 음식점업, 숙박업, 목욕장업, 체육시설업 등 } \\
\text { 관광진흡법 규정 상관광업체 업종에 } \\
\text { 해당하지 않지만 함께 훈영하고 있는 업종 }\end{array}$}} \\
\hline \multicolumn{2}{|c|}{ 합 게 $※$ 모든 업좀의 매출액 비중 합은 100 이 되어야 합니다. } & 1 & 0 & 0 & $\%$ & & \\
\hline
\end{tabular}

관광산업특수분류에 기초한 통계조사 시에도 동일한 방식의 항목을 반영할 수 있 다. 단, 기존 관광사업체조사 대비 대상 업종(세분류 기준) 수가 상당히 많이 늘어났 기 때문에 이 업종들을 모두 설문지 상에 제시할 경우 응답자 부담감 증가가 불가피 하다. 이 점을 고려하여 본 조사 시에는 별도의 보기카드 형태로 조사 대상 업종을 목록화하여 제시한 후 해당되는 업종(복수 등록한 업종)에 한해 각 업종 간 관광비를 설문지 상에 작성할 수 있도록 구성하고자 한다. 아울러 조사 전 명부 정리 단계에서 복수 업종 등록 사업체를 최대한으로 선별해내는 작업도 매우 중요한 과정이다. 사 
전에 복수 업종 등록 사업체 파악이 될 경우 현장조사 시 보다 효율적인 진행이 가능 하기 때문이다. 업종 간 중복 등록 여부 파악을 위한 연계코드로 활용될 수 있는 정 보로는 일반적으로 사업체명, 연락처, 소재지 등이 해당된다. 하지만 이러한 정보는 지역, 업종 특성에 따라 기재 방식에 차이가 존재하기 때문에 정확한 연계를 위한 정보로 활용하기에는 한계가 존재한다. 가장 확실한 대안은 사업체 고유식별번호라 할 수 있는 사업자등록번호를 활용하는 것이지만, 본 조사 대상 사업체 전수에 대한 번호를 확보하기에는 현실적으로 어려운 점이 많은 상태이므로 통계청, 국세청 등 유관 기관과 해당 정보 확보 방안에 대한 지속적인 논의가 필요할 것으로 여겨진다.

\section{나. 업종별 관광비 산출 방안(관광산업 요소 비중 적용)}

다음으로 고려되어야 할 사안은 본 조사 대상 업종별로 과연 관광산업과 얼마나 관련이 있는지에 대해 검토를 하는 것이다. 즉, 앞서 기술한 업종간 관광비 산출을 통해 중복 데이터가 보정됨과 동시에 각 업종별로 영위하고 있는 산업활동 중 '관광 산업 요소가 차지하고 있는 비중'이 함께 산출되어야 한다. 예를 들어 핵심 관광산 업 업종 중 '관광 인증 모텔업'의 매출액은 온전히 관광객을 통해서만 얻어진 수입 은 아닐 것이기 때문이다. 특정 산업에 대한 '요소 비중' 산출을 통한 시장 규모 추 정을 하고 있는 가장 대표적인 산업 분야는 현재 저작권산업이다. 저작권산업의 경 우도 관광산업과 동일하게 '저작권산업 특수분류체계'가 제정(2011년)되어 있으며, 관련 업종들을 핵심 저작권산업, 상호의존 저작권산업, 부분 저작권산업, 저작권 지 원산업 4 개 분야로 분류하여 2013년부터 현재까지 매년 시장규모를 추정, 공표하 고 있다. 특히 저작권산업의 경우 각 분야별로 비교적 명확한 요소비중 산출 기준 (WIPO의 저작권산업에 대한 요소비중 조사 매뉴얼)을 준용하여 시장 규모 추정 시 각 분야별 저작권산업 요소비중을 적용하고 있다, 하지만 관광산업의 경우 조사대 상 범위에 대한 확대가 논의되고 있는 단계이고, 조사대상 범위 또한 매우 넓기 때 문에 관련 사안에 대한 후속연구를 통해 보다 구체적인 논의가 이루어져야하는 실 정이다. 단, 저작권산업의 요소비중을 적용한 시장규모 산출 방법을 본 조사에도 접 목시킬 수 있을지에 대한 검토를 위해 핵심 관광산업 내 일부 업종에 대한 시범조사 를 진행하였으며, 구체적 조사설계 내역은 다음 〈표4-40〉과 같다. 
〈표 4-40〉핵심 관광산업 부문 관광산업 요소비중 산출을 위한 시범조사 - 기본 설계

\begin{tabular}{|c|c|c|}
\hline 구분 & 세부 내용 & 비고 \\
\hline 모집단 & $\begin{array}{l}\text { 관광산업특수분류체계 기준 } 6 \text { 개 업종 } 19,237 \text { 개 사업체 } \\
\text { (관광 인증 모텔업, 민박업, 게스트하우스, 레지던스호텔, } \\
\text { 산림휴양림업, 기타 관광 숙박시설 운영업) }\end{array}$ & $\begin{array}{l}\mathrm{KSIC10} \text { 세세분류 기준 } \\
\text { 여관업, 민박업, 기타 } \\
\text { 일반 및 생활 숙박시설 } \\
\text { 운영업 해당 }\end{array}$ \\
\hline 표본추출틀 & 2017년 기준 사업체 총 조사 & - \\
\hline 표본크기 & 356 & - \\
\hline 오차범위 & $95 \%$ 신뢰수준에서 $\pm 5.1 \% p$ & \\
\hline 표본배분 & $\begin{array}{l}\text { 1차 층화: 관광산업특수분류 중분류 기준 (6개) } \\
\text { 2차 층화: 종사자 규모 (4개) }\end{array}$ & $\begin{array}{l}\text { 5인 미만, 5-9인, } \\
\text { 10 19인, 20인 이상 }\end{array}$ \\
\hline 조사방법 & CATI(Computer Aided Telephone Interview) 조사 & - \\
\hline 조사도구 & 구조화된 설문지 & - \\
\hline 조사기간 & 2020년 8월 18일 2020년 8월 28일 (10일 간) & - \\
\hline
\end{tabular}

조사 대상 업종은 모두 숙박 관련 업종으로 설정하였으며, 각 업종별 관광산업 요소비중 산출을 위해 활용된 설문 내용은 다음 〈표 4-41〉과 같다.

〈표 4-41〉 핵심 관광산업 부문 관광산업 요소비중 산출을 위한 시범조사 - 설문 내용

\begin{tabular}{c|l}
\hline \multicolumn{1}{|c}{ 구분 } & \multicolumn{1}{c}{ 세부 내용 } \\
\hline 사업체 기본정보 & 법인명, 상호명, 조직형태, 소재지, 객실 수, 총 종사자 수 \\
\hline \multirow{3}{*}{ 매출 부문 } & 2019년 기준 연간 총 매출액 \\
& 2019년 기준 연간 총 매출액 중 관광활동 관련 매출액 비중 \\
& 관광활동 매출액 중 내외국인 비중 \\
& 관광활동 매출액 중 단체여행/개별여행 비중 \\
\hline \multirow{2}{*}{ 지출 부문 } & 2019년 기준 연간 총 지출액 \\
& 2019년 기준 연간 총 지출액 관광활동 관련 지출액 비중 \\
\hline \multirow{2}{*}{ 관광활동 수요 } & $\begin{array}{l}\text { 사업체 운영 시 관광활동 중요도 } \\
\text { 향후 관광활동을 통한 사업 확대 의향 }\end{array}$ \\
\hline
\end{tabular}

주요 조사 결과를 살펴보면, 2019 년 평균 매출액은 1 억 1,843 만 원이었으며, 업 종별로 구분해서 살펴보면 ‘레지던스 호텔’이 9억 8,606만 원, '관광인증모텔업’이 2억 6,270만원, '산림휴양업'이 1 억 2,436만원 등의 순으로 높았다.

관광활동을 통한 매출액 평균 비중은 $80.7 \%$ 로 나타났으며, 업종별로는 '산림휴 
양업’이 96.8\%로 가장 높게 나타났으며 이어서 ‘레지던스 호텔'(94.4\%), ‘민박업' (93.7\%) 순으로 나타났다.

〈표 4-42〉 업종별 평균 매출액 및 관광활동을 통한 매출액 평균 비중

\begin{tabular}{|c|c|c|c|}
\hline & 구분 & 평균 매출액 & $\begin{array}{l}\text { 관광활동을 통한 } \\
\text { 매출액 평균 비중 }\end{array}$ \\
\hline \multirow{6}{*}{ 업종 } & 관광 인증 모텔업 & 2억 6,270만 원 & $62.5 \%$ \\
\hline & 민박업 & 3,805 만 원 & $93.7 \%$ \\
\hline & 게스트하우스 & 7,453만 원 & $91.7 \%$ \\
\hline & 산림휴양림업 & 1억 2,436만 원 & $96.8 \%$ \\
\hline & 레지던스호텔 & 9억 8,606만 원 & $94.4 \%$ \\
\hline & 기타 관광 숙박시설 운영업 & 8,990만 원 & $66.8 \%$ \\
\hline 전체 & & 1억 1,843만 원 & $80.7 \%$ \\
\hline
\end{tabular}

〈표 4-43〉 업종별×지역별 관광활동을 통한 매출액 평균 비중

\begin{tabular}{|c|c|c|c|c|c|c|}
\hline \multirow{2}{*}{\multicolumn{2}{|c|}{ 구분 }} & \multicolumn{4}{|c|}{ 관광활동 매출액 구간 비율 } & \multirow{2}{*}{ 평균 } \\
\hline & & 0 20\% 이하 & 21 60\% 이하 & $61 \sim 99 \%$ 이하 & $100 \%$ & \\
\hline \multicolumn{2}{|c|}{ 전체 } & 12.1 & 10.1 & 15.4 & 62.4 & 80.7 \\
\hline \multirow{6}{*}{$\begin{array}{c}\text { 관광 } \\
\text { 인증 } \\
\text { 모텔업 }\end{array}$} & 수도권 & 13.0 & 23.2 & 15.3 & 48.4 & 72.5 \\
\hline & 영남 & 38.1 & 15.1 & 25.5 & 21.2 & 52.9 \\
\hline & 충청 & 44.0 & 17.6 & 29.5 & 8.8 & 42.5 \\
\hline & 호남 & 16.0 & 23.1 & 23.0 & 37.9 & 67.5 \\
\hline & 제주 & 0.0 & 37.4 & 62.6 & 0.0 & 79.4 \\
\hline & 강원 & 24.9 & 0.0 & 54.2 & 20.9 & 67.6 \\
\hline \multirow{6}{*}{ 민박업 } & 수도권 & 3.8 & 3.8 & 9.4 & 83.1 & 93.1 \\
\hline & 영남 & 0.0 & 0.0 & 6.5 & 93.5 & 98.7 \\
\hline & 충청 & 4.9 & 12.2 & 7.3 & 75.6 & 87.6 \\
\hline & 호남 & 0.0 & 4.2 & 8.3 & 87.5 & 96.7 \\
\hline & 제주 & 0.0 & 0.0 & 10.8 & 89.2 & 96.8 \\
\hline & 강원 & 0.0 & 6.6 & 19.7 & 73.8 & 94.1 \\
\hline \multirow{6}{*}{ 게스트하우스 } & 수도권 & 0.0 & 16.2 & 16.2 & 67.6 & 93.0 \\
\hline & 영남 & 16.5 & 0.0 & 33.0 & 50.5 & 81.9 \\
\hline & 충청 & 100.0 & 0.0 & 0.0 & 0.0 & 20.0 \\
\hline & 호남 & 0.0 & 0.0 & 0.0 & 100.0 & 100.0 \\
\hline & 제주 & 0.0 & 0.0 & 50.0 & 50.0 & 99.5 \\
\hline & 강원 & 0.0 & 0.0 & 0.0 & 100.0 & 100.0 \\
\hline
\end{tabular}




\begin{tabular}{|c|c|c|c|c|c|c|}
\hline \multirow{2}{*}{\multicolumn{2}{|c|}{ 구분 }} & \multicolumn{4}{|c|}{ 관광활동 매출액 구간 비율 } & \multirow{3}{*}{$\begin{array}{l}\text { 평균 } \\
100.0 \\
\end{array}$} \\
\hline & & \multirow{2}{*}{$\begin{array}{c}0 \sim 20 \% \text { 이하 } \\
0.0\end{array}$} & \multirow{2}{*}{\begin{tabular}{|c|}
$21 ~ 60 \%$ 이하 \\
0.0
\end{tabular}} & \multirow{2}{*}{\begin{tabular}{|c|}
$61 ~ 99 \%$ 이하 \\
0.0
\end{tabular}} & \multirow{2}{*}{$\begin{array}{l}100 \% \\
100.0 \\
\end{array}$} & \\
\hline \multirow{3}{*}{ 산림휴양림업 } & 영남 & & & & & \\
\hline & 호남 & 0.0 & 0.0 & 89.6 & 10.4 & 95.5 \\
\hline & 강원 & 0.0 & 0.0 & 0.0 & 100.0 & 100.0 \\
\hline \multirow{2}{*}{ 레지던스호텔 } & 수도권 & 0.0 & 0.0 & 80.0 & 20.0 & 91.0 \\
\hline & 영남 & 0.0 & 0.0 & 0.0 & 100.0 & 100.0 \\
\hline \multirow{6}{*}{$\begin{array}{c}\text { 기타 관광 } \\
\text { 숙박시설 운영업 }\end{array}$} & 수도권 & 50.8 & 14.6 & 6.2 & 28.5 & 38.9 \\
\hline & 영남 & 35.5 & 1.8 & 0.0 & 62.7 & 63.3 \\
\hline & 충청 & 28.6 & 14.3 & 7.1 & 50.0 & 63.1 \\
\hline & 호남 & 10.8 & 0.0 & 21.6 & 67.5 & 85.8 \\
\hline & 제주 & 0.0 & 44.6 & 55.4 & 0.0 & 66.6 \\
\hline & 강원 & 16.0 & 0.0 & 0.0 & 84.0 & 87.2 \\
\hline
\end{tabular}

관광활동 매출액을 내/외국인으로 구분해 보면, '내국인'이 $91.2 \%$, '외국인'이 $8.8 \%$ 로 조사되었으며, 개별/단체 여행의 비중을 구분하였을 때는 '개별여행'이 $87.3 \%$ 로 ‘단체여행'(12.7\%)보다 높게 나타났다.

〈표 4-44〉 내/외국인 및 단체/개별 관광객 매출액 비중

\begin{tabular}{c|c|c|c}
\hline \multicolumn{2}{c|}{$\begin{array}{c}\text { 관광활동 매출액 중 내/외국인 } \\
\text { 매출액 비중 }\end{array}$} & \multicolumn{2}{c}{$\begin{array}{c}\text { 관광활동 매출액 중 단체/개별여행 } \\
\text { 매출액 비중 }\end{array}$} \\
\hline 내국인 & $91.2 \%$ & 단체여행 & $12.7 \%$ \\
\hline 외국인 & $8.8 \%$ & 개별여행 & $87.3 \%$ \\
\hline
\end{tabular}

2019년 평균 지출액은 6,878만 원이었으며, 업종별로 구분해서 살펴보면 '레지 던스 호텔'이 2억 1,106만원, '관광인증모텔업'이 1억 5,939만원, '산림휴양업'이 6,732 만원 등의 순으로 높았다.

관광활동을 통한 지출액 평균 비중은 $5.5 \%$ 로 나타났으며, 업종별로는 '레지던스 호텔'이 $16.8 \%$ 로 가장 높게 나타났으며 이어서 '게스트하우스'( $11.8 \%)$, '산림휴양 업' $(8.5 \%)$ 순으로 나타났다. 실제 조사된 업종에서 관광을 통한 매출액은 매우 높은 반면 관광활동을 위한 지출액은 약 $5.5 \%$ 정도로 나타나 해당 업종들의 관광객 유치 를 위한 노력은 높지 않은 것으로 판단된다. 
〈표 4-45〉업종별 평균 지출액 및 관광활동을 위한 평균 지출액

\begin{tabular}{c|c|c|c}
\hline \multicolumn{2}{c|}{ 구분 } & 평균 지출액 & $\begin{array}{c}\text { 관광활동을 위한 } \\
\text { 지출액 평균 비중 }\end{array}$ \\
\hline \multirow{4}{*}{ 업종 } & 관광 인증 모텔업 & 1억 5,939만 원 & $8.3 \%$ \\
\cline { 2 - 4 } & 민박업 & 2,244 만 원 & $3.1 \%$ \\
\cline { 2 - 4 } & 게스트하우스 & 3,086만 원 & $11.8 \%$ \\
\cline { 2 - 4 } & 산림휴양림업 & 6,732 만 원 & $8.5 \%$ \\
\cline { 2 - 4 } & 레지던스호텔 & 2억 1,106만 원 & $16.8 \%$ \\
\cline { 2 - 4 } & 기타 관광 숙박시설 운영업 & 4,230만 원 & $6.3 \%$ \\
\hline \multirow{2}{*}{ 전체 } & & 6,878 만 원 & $5.5 \%$ \\
\hline
\end{tabular}

관광활동이 중요하다는 의견은 56.5\%(중요하다 $37.7 \%+$ 매우 중요하다 $18.8 \%$ ), 향후 확대 의향은 $22.5 \%$ (그렇다 $19.1 \%$ + 매우 그렇다 $3.4 \%$ )로 조사되었다.

〈표 4-46〉 관광활동 중요성 및 향후 확대 의향

\begin{tabular}{|c|c|c|c|c|c|c|c|c|}
\hline \multirow[b]{2}{*}{ 구분 } & \multirow{2}{*}{$\begin{array}{l}\text { 전혀 } \\
\text { 중요하 } \\
\text { 지 않다 }\end{array}$} & \multirow{2}{*}{$\begin{array}{l}\text { 중요하 } \\
\text { 지 않다 }\end{array}$} & \multirow{2}{*}{$\begin{array}{l}\text { 보통 } \\
\text { 이다 }\end{array}$} & \multirow{2}{*}{$\begin{array}{l}\text { 중요 } \\
\text { 하다 }\end{array}$} & \multirow{2}{*}{$\begin{array}{l}\text { 매우 } \\
\text { 중요 } \\
\text { 하다 }\end{array}$} & \multicolumn{3}{|c|}{ 종합평가 } \\
\hline & & & & & & $\begin{array}{c}\text { 중요하지 } \\
\text { 않음 }\end{array}$ & 보통 & 중요함 \\
\hline 관광활동 중요성 & 3.8 & 13.2 & 26.6 & 37.7 & 18.8 & 16.9 & 26.6 & 56.5 \\
\hline \multirow[b]{2}{*}{ 구분 } & \multirow{2}{*}{$\begin{array}{l}\text { 전혀 } \\
\text { 그렇지 } \\
\text { 않다 }\end{array}$} & \multirow[b]{2}{*}{$\begin{array}{l}\text { 그렇지 } \\
\text { 않다 }\end{array}$} & \multirow[b]{2}{*}{$\begin{array}{l}\text { 보통 } \\
\text { 이다 }\end{array}$} & \multirow[b]{2}{*}{ 그렇다 } & \multirow[b]{2}{*}{$\begin{array}{l}\text { 매우 } \\
\text { 그렇다 }\end{array}$} & \multicolumn{3}{|c|}{ 종합평가 } \\
\hline & & & & & & $\begin{array}{c}\text { 중요하지 } \\
\text { 않음 }\end{array}$ & 보통 & 중요함 \\
\hline $\begin{array}{l}\text { 관광활동 } \\
\text { 확대 의향 }\end{array}$ & 22.7 & 40.5 & 14.3 & 19.1 & 3.4 & 63.2 & 14.3 & 22.5 \\
\hline
\end{tabular}

본 조사 결과를 '제 3절' 에서 기술한 표본설계에 입각하여 추정된 관련 업종별 조사 결과에 적용할 경우 보다 정확한 관광산업 시장 규모를 산출할 수 있다. 단, 본 조사 결과를 어느 정도 수준까지 반영할 지에 대해서는 추가적인 논의가 필요하 다. 보다 층을 세분화(예: 해당 업종 기준 종사자 규모별 또는 내/외국인별로 세분화 하여 결과 적용)하여 결과를 반영하기 위해서는 우선 신뢰도를 담보할 수 있는 충분 한 표본크기 확보가 전제되어야하기 때문이다. 
이와 같은 조사 방식을 통해 관광산업 요소비중을 파악할 필요가 있는 업종은 시 범조사를 통해 진행한 업종 외에도 상당수가 존재한다. 관련 업종들을 모두 포괄하 기 위해서는 무엇보다 조사 대상이 될 업종을 선별하는 과정이 선행되어야 한다고 여겨지며, 이를 위해 기존 품목분석(통계청 사업체총조사 결과 중 각 사업체별 주사 업, 부사업 정보를 검토하여 관광산업 식별 여부 판단) 결과 관광산업 식별 비중이 상대적으로 낮은 사업체 현황을 살펴보았다(표 4-47,4-48).

검토 결과 관광산업 식별비중이 $20 \%$ 미만인 사업체 수(분류정보의 부족으로 관 광사업체 식별이 어려운 사업체 포함)는 총 640,966 개소(88.7\%)이며, 총 종사자수 는 2,403,344명(82.0\%)에 해당된다. 이를 좀 더 세부적으로 살펴보면, $10 \%$ 미만의 사업체 수는 총 174,774 개소(24.2\%), 총 종사자수는 $1,129,631$ 명(38.5\%)에 해당 되며, 10 20\% 미만의 사업체 수는 466,192개소(64.5\%), 총 종사자수는 1,273,713 명(43.5\%)에 해당된다. 전체 모집단에서 관련 사업체 수가 차지하는 비중을 고려할 때 해당 사업체들은 관광산업 요소비중 파악을 위한 조사가 이루어져야 할 최우선 대상이 되어야할 것으로 여겨진다. 업종별로는 ‘레저 및 스포츠용품 소매업’, ‘택시 운송업’, ‘기타 관광 레크레이션 교육기관' 등의 경우 관광산업 식별이 어려운 업종, '관광 전문 교육기관(고등학교)', '레저용 의복 소매업', '시내외버스운송업‘ 등의 경 우 관광산업 식별 비중이 다른 업종 대비 상대적으로 낮은 수준으로 파악되었다. 단, 본 검토 결과는 분류정보의 부족, 연구자의 주관적 판단 개입 가능성 등 정확한 분류가 어렵다는 점을 감안한 결과이므로 최종적인 관광산업 요소비중 파악을 위한 조사 대상 업종은 관심 업종별 파일럿 테스트, 가용 예산/시간 등을 복합적으로 고 려하여 신중히 결정할 필요가 있다고 여겨진다. 예를 들어 관광산업 식별 비중이 낮은 업종(예: 관광산업 식별비중 $20 \%$ 미만)의 경우 매년 사전 조사 형태로 요소비 중을 파악하여 추정 결과에 적용하되 관광산업 식별 비중이 상대적으로 높은 업종 의 경우 매년 조사가 아닌 적정 주기별 요소비중 산출을 통해 추정 결과에 적용하는 방식이다. 특히 분류정보의 부족으로 명확한 식별비중 파악이 어려운 일부 업종의 경우 관광산업 포함 여부를 결정하기 위한 명확한 기준 정립이 선행되어야 하며, 정립된 기준을 어느 수준까지 충족할 경우 관광산업으로 포함시킬지 등에 대해서도 지속적인 논의가 필요하다고 여겨진다. 
〈표 4-47〉 관광산업특수분류 중분류별 관광산업 식별 비중과 변동계수 현황

\begin{tabular}{|c|c|c|c|c|c|c|}
\hline \multirow{2}{*}{ 대분류 } & \multirow{2}{*}{ 중분류 } & \multicolumn{2}{|c|}{ 사업체수 } & \multicolumn{3}{|c|}{ 종사자수 } \\
\hline & & 관광산업 & 비중 & 총합 & 평균 & 변동계수 \\
\hline \multirow{9}{*}{$\begin{array}{l}\text { 핵심 } \\
\text { 관광 } \\
\text { 산업 }\end{array}$} & 관광 쇼핑업(도매업 제외) & 1,237 & $83.4 \%$ & 6,453 & 5.2 & 4.68 \\
\hline & 관광 운수업 & 1,420 & $90.9 \%$ & 59,330 & 41.8 & 9.86 \\
\hline & 관광 숙박업 & 24,107 & $76.3 \%$ & 109,991 & 4.6 & 7.32 \\
\hline & 관광 음식점 및 주점업 & 1,468 & $5.9 \%$ & 9,962 & 6.8 & 3.08 \\
\hline & 여행사 및 여행보조 서비스업 & 6,780 & $67.1 \%$ & 33,066 & 4.9 & 3.72 \\
\hline & 국제회의업a & 219 & $64.6 \%$ & 3,559 & 16.3 & 3.52 \\
\hline & 문화, 오락 및 레저 스포츠산업 & 7,391 & $93.3 \%$ & 103,278 & 14.0 & 4.18 \\
\hline & 카지노업a & 16 & $100.0 \%$ & 8,728 & 545.5 & 1.40 \\
\hline & 소계 & 42,638 & $54.9 \%$ & 334,367 & 7.8 & 10.93 \\
\hline \multirow{5}{*}{$\begin{array}{l}\text { 상호 } \\
\text { 의존 } \\
\text { 관광 } \\
\text { 산업 }\end{array}$} & 관광 건설업 & 192 & $7.5 \%$ & 2,684 & 14.0 & 1.36 \\
\hline & 관광 및 레저용품 소매업 & 3,962 & $16.1 \%$ & 6,374 & 1.6 & 0.87 \\
\hline & 관광보험및금융서비스업 & 511 & $15.6 \%$ & 1,029 & 2.0 & 2.57 \\
\hline & 레저장비업 & 4,268 & $95.5 \%$ & 15,347 & 3.6 & 2.99 \\
\hline & 소계 & 8,933 & $25.6 \%$ & 25,434 & 2.8 & 2.92 \\
\hline \multirow{7}{*}{$\begin{array}{l}\text { 부분 } \\
\text { 적용 } \\
\text { 관광 } \\
\text { 산업 }\end{array}$} & 관광 비인증 쇼핑업 & 5 & $0.0 \%$ & 22 & 4.4 & 1.25 \\
\hline & 부분관광 운송업 & 1,138 & $20.7 \%$ & 22,866 & 20.1 & 3.21 \\
\hline & 부분관광 숙박업 & 15,604 & $85.5 \%$ & 41,285 & 2.6 & 1.87 \\
\hline & 부분관광 음식점 및 주점업 & 77,393 & $17.8 \%$ & 159,816 & 2.1 & 0.80 \\
\hline & 부분관광 공연장업 & 337 & $75.1 \%$ & 1,030 & 3.1 & 1.91 \\
\hline & 부분관광 기타 서비스업 & 424 & $19.5 \%$ & 6,422 & 15.1 & 1.85 \\
\hline & 소계 & 94,901 & $16.4 \%$ & 231,441 & 2.4 & 3.29 \\
\hline \multirow{5}{*}{$\begin{array}{l}\text { 관광 } \\
\text { 지원 } \\
\text { 산업 }\end{array}$} & 관광 연구 개발업 & 26 & $12.8 \%$ & 847 & 32.6 & 1.68 \\
\hline & 관광 공공기관 & 193 & $5.6 \%$ & 13,546 & 70.2 & 3.27 \\
\hline & 관광 교육서비스업 & 155 & $0.6 \%$ & 1244 & 8.0 & 4.63 \\
\hline & 관광 단체 & 206 & $100.0 \%$ & 741 & 3.6 & 1.91 \\
\hline & 소계 & 580 & $1.8 \%$ & 16,378 & 28.2 & 4.87 \\
\hline \multicolumn{2}{|r|}{ 전체 } & 147,052 & $20.3 \%$ & 607,620 & 4.1 & 11.50 \\
\hline
\end{tabular}

※ 비중: 전체 사업체 중에서 품목분석을 통해 관광산업으로 식별되는 사업체의 비중 
〈표 4-48〉 관광산업특수분류 소분류별 관광산업 식별 비중 현황

\begin{tabular}{|c|c|c|c|c|c|c|c|c|}
\hline \multirow{2}{*}{ 대분류 } & \multirow{2}{*}{ 중분류 } & \multirow{2}{*}{ 소분류 } & \multicolumn{3}{|c|}{ 사업체수 } & \multicolumn{3}{|c|}{ 종사자수 } \\
\hline & & & 관광산업 & 비중 & 전체 & 관광산업 & 비중 & 전체 \\
\hline \multirow{33}{*}{$\begin{array}{l}\text { 핵심 } \\
\text { 관광 } \\
\text { 산업 }\end{array}$} & \multirow{4}{*}{$\begin{array}{c}\text { 관광 } \\
\text { 쇼핑업 } \\
\text { (도매업 } \\
\text { 제외) }\end{array}$} & 면세점 & 43 & $100 \%$ & 43 & 3,595 & $100 \%$ & 3,595 \\
\hline & & $\begin{array}{c}\text { 외국인전용 관광기념품 } \\
\text { 판매업a }\end{array}$ & 1,064 & $92.4 \%$ & 1,152 & 2,432 & $95.5 \%$ & 2,547 \\
\hline & & 관광 인증 쇼핑업 & 130 & $45.1 \%$ & 288 & 426 & $43.6 \%$ & 976 \\
\hline & & 소계 & 1,237 & $83.4 \%$ & 1,483 & 6,453 & $90.7 \%$ & 7,118 \\
\hline & \multirow{9}{*}{$\begin{array}{c}\text { 관광 } \\
\text { 운수업 }\end{array}$} & 관광 철도운송업 & . & & 109 & & & 2,951 \\
\hline & & 시내순환 관광업a & 2 & $100 \%$ & 2 & 4 & $100 \%$ & 4 \\
\hline & & 전세버스 운송업 & 1,180 & $99.8 \%$ & 1,182 & 27,645 & $99.8 \%$ & 27,694 \\
\hline & & 관광궤도업 & 18 & $94.7 \%$ & 19 & 527 & $99.4 \%$ & 530 \\
\hline & & 관광 유람선업a & 100 & $100 \%$ & 100 & 1,138 & $100 \%$ & 1,138 \\
\hline & & 크루즈업a & 14 & $77.8 \%$ & 18 & 142 & $57.7 \%$ & 246 \\
\hline & & 관광 항공 정기운송업 & 105 & $79.5 \%$ & 132 & 29,868 & $91.6 \%$ & 32,607 \\
\hline & & 관광 항공 부정기운송업 & 1 & $100 \%$ & 1 & 6 & $100 \%$ & 6 \\
\hline & & 소계 & 1,420 & $90.9 \%$ & 1,563 & 59,330 & $91.0 \%$ & 65,176 \\
\hline & \multirow{15}{*}{$\begin{array}{c}\text { 관광 } \\
\text { 숙박업 }\end{array}$} & 관광 호텔업a & 817 & $100 \%$ & 817 & 47,381 & $100 \%$ & 47,381 \\
\hline & & 가족 호텔업a & 10 & $100 \%$ & 10 & 243 & $100 \%$ & 243 \\
\hline & & 호스텔업a & 151 & $95.0 \%$ & 159 & 718 & $90.2 \%$ & 796 \\
\hline & & 휴양콘도미니엄업a & 311 & $100 \%$ & 311 & 16,718 & $100 \%$ & 16,718 \\
\hline & & 관광 펜션업a & 10,035 & $100 \%$ & 10,035 & 20,545 & $100 \%$ & 20,545 \\
\hline & & 산림휴양림업 & 31 & $100 \%$ & 31 & 133 & $100 \%$ & 133 \\
\hline & & 게스트하우스 & 909 & $100 \%$ & 909 & 1,663 & $100 \%$ & 1,663 \\
\hline & & 레지던스 호텔 & 32 & $100 \%$ & 32 & 189 & $100 \%$ & 189 \\
\hline & & 관광 인증 모텔업 & . & & 6,078 & & & 22,298 \\
\hline & & 민박업 & 9,977 & $100 \%$ & 9,977 & 17,140 & $100 \%$ & 17,140 \\
\hline & & $\begin{array}{c}\text { 외국인 관광 도시민박업 } \\
\text { (홈스테이)a }\end{array}$ & 23 & $100 \%$ & 23 & 43 & $100 \%$ & 43 \\
\hline & & 자동차 야영장업a & 860 & $100 \%$ & 860 & 2,349 & $100 \%$ & 2,349 \\
\hline & & 한옥체험업a & 152 & $100 \%$ & 152 & 331 & $100 \%$ & 331 \\
\hline & & 기타 관광 숙박시설 운영업 & 799 & $36.1 \%$ & 2,215 & 2,538 & $52.8 \%$ & 4,810 \\
\hline & & 소계 & 24,107 & $76.3 \%$ & 31,609 & 109,991 & $81.7 \%$ & 134,639 \\
\hline & \multirow{5}{*}{$\begin{array}{l}\text { 관광 } \\
\text { 음식점 } \\
\text { 및 } \\
\text { 주점업 }\end{array}$} & 관광 식당업a & 624 & $4.2 \%$ & 14,707 & 6,398 & $5.2 \%$ & 123,662 \\
\hline & & 관광 유흥음식점업a & 482 & $5.1 \%$ & 9,536 & 1,365 & $5.3 \%$ & 25,985 \\
\hline & & 관광 극장유흥업a & 56 & $54.4 \%$ & 103 & 1,293 & $70.5 \%$ & 1,835 \\
\hline & & 외국인전용 유흥음식점업a & 306 & $93.0 \%$ & 329 & 906 & $78.7 \%$ & 1,151 \\
\hline & & 소계 & 1,468 & $5.9 \%$ & 24,675 & 9,962 & $6.5 \%$ & 152,633 \\
\hline
\end{tabular}




\begin{tabular}{|c|c|c|c|c|c|c|c|c|}
\hline \multirow{2}{*}{ 대분류 } & \multirow{2}{*}{ 중분류 } & \multirow{2}{*}{ 소분류 } & \multicolumn{3}{|c|}{ 사업체수 } & \multicolumn{3}{|c|}{ 종사자수 } \\
\hline & & & 관광산업 & 비중 & 전체 & 관광산업 & 비중 & 전체 \\
\hline & \multirow{5}{*}{$\begin{array}{c}\text { 여행사 } \\
\text { 및 여행 } \\
\text { 보조 } \\
\text { 서비스업 }\end{array}$} & 일반 여행업a & 4,262 & $56.2 \%$ & 7,578 & 20,223 & $54.6 \%$ & 37,013 \\
\hline & & 국외 여행업 & 837 & $100 \%$ & 837 & 3,783 & $100 \%$ & 3,783 \\
\hline & & 국내 여행업a & 713 & $100 \%$ & 713 & 3,560 & $100 \%$ & 3,560 \\
\hline & & 여행보조 및 예약 서비스업 & 968 & $99.7 \%$ & 971 & 5,500 & $99.7 \%$ & 5,514 \\
\hline & & 소계 & 6,780 & $67.1 \%$ & 10,099 & 33,066 & $66.3 \%$ & 49,870 \\
\hline & \multirow{3}{*}{$\begin{array}{c}\text { 국제 } \\
\text { 회의업a }\end{array}$} & 국제회의 기획업a & 217 & $64.4 \%$ & 337 & 3,523 & $75.3 \%$ & 4,677 \\
\hline & & 국제회의 시설업a & 2 & $100 \%$ & 2 & 36 & $100 \%$ & 36 \\
\hline & & 소계 & 219 & $64.6 \%$ & 339 & 3,559 & $75.5 \%$ & 4,713 \\
\hline & \multirow{17}{*}{$\begin{array}{l}\text { 문화, } \\
\text { 오락 및 } \\
\text { 레저 } \\
\text { 스포츠 } \\
\text { 산업 }\end{array}$} & 박물관 운영업(미술관 포함) & 1,379 & $100 \%$ & 1,379 & 12,811 & $100 \%$ & 12,811 \\
\hline & & 사적지 관리 운영업 & 216 & $100 \%$ & 216 & 2,822 & $100 \%$ & 2,822 \\
\hline & & 식물원, 동물원 운영업 & 169 & $100 \%$ & 169 & 3,265 & $100 \%$ & 3,265 \\
\hline & & 자연공원 운영업 & 391 & $100 \%$ & 391 & 9,191 & $100 \%$ & 9,191 \\
\hline & & 기타 관광지 운영업 & 15 & $88.2 \%$ & 17 & 145 & $97.3 \%$ & 149 \\
\hline & & 종합유원시설업a & 15 & $46.9 \%$ & 32 & 6,977 & $87.0 \%$ & 8,016 \\
\hline & & 일반유원시설업 & 151 & $73.3 \%$ & 206 & 1,639 & $95.2 \%$ & 1,721 \\
\hline & & 기타유원시설업a & 1,288 & $96.5 \%$ & 1,335 & 3,821 & $96.1 \%$ & 3,974 \\
\hline & & 농어촌 체험 및 생태 관광업 & 46 & $100 \%$ & 46 & 389 & $100 \%$ & 389 \\
\hline & & 관광 공연시설 운영업 & 53 & $48.2 \%$ & 110 & 2,457 & $56.1 \%$ & 4,379 \\
\hline & & 경주장 운영업 & 15 & $100 \%$ & 15 & 4,175 & $100 \%$ & 4,175 \\
\hline & & 골프장 운영업 & 433 & $100 \%$ & 433 & 44,837 & $100 \%$ & 44,837 \\
\hline & & 스키장 운영업 & 2 & $100 \%$ & 2 & 585 & $100 \%$ & 585 \\
\hline & & 낚시장 운영업 & 892 & $100 \%$ & 892 & 1,656 & $100 \%$ & 1,656 \\
\hline & & $\begin{array}{l}\text { 수상 오락 서비스업 } \\
\text { (유원시설 제외) }\end{array}$ & 598 & $100 \%$ & 598 & 2,117 & $100 \%$ & 2,117 \\
\hline & & 오락 및 관광체험시설 운영 & 1,728 & $83.1 \%$ & 2,080 & 6,391 & $80.4 \%$ & 7,951 \\
\hline & & 소계 & 7,391 & $93.3 \%$ & 7,921 & 103,278 & $95.6 \%$ & 108,038 \\
\hline & \multirow{3}{*}{$\begin{array}{l}\text { 카지 } \\
\text { 노업a }\end{array}$} & 외국인 전용 카지노업 & 15 & $100 \%$ & 15 & 5,579 & $100 \%$ & 5,579 \\
\hline & & 내국인 출입 카지노업 & 1 & $100 \%$ & 1 & 3,149 & $100 \%$ & 3,149 \\
\hline & & 소계 & 16 & $100 \%$ & 16 & 8,728 & $100 \%$ & 8,728 \\
\hline \multirow{5}{*}{$\begin{array}{l}\text { 상호 } \\
\text { 의존 } \\
\text { 관광 } \\
\text { 산업 }\end{array}$} & \multirow{5}{*}{$\begin{array}{l}\text { 관광 } \\
\text { 건설업 }\end{array}$} & 상업 및 휴양 건물 건설업 & 123 & $100 \%$ & 123 & 1,970 & $100 \%$ & 1,970 \\
\hline & & 관광용지 개발조성공사 & 4 & $80.0 \%$ & 5 & 8 & $80.0 \%$ & 10 \\
\hline & & $\begin{array}{c}\text { 관광지, 관광단지 또는 } \\
\text { 관광특구 }\end{array}$ & 27 & $1.1 \%$ & 2,363 & 228 & $2.1 \%$ & 10,707 \\
\hline & & $\begin{array}{l}\text { 관광 관련 기타 } \\
\text { 토목시설물 건설 }\end{array}$ & 38 & $57.6 \%$ & 66 & 478 & $78.1 \%$ & 612 \\
\hline & & 소계 & 192 & $7.5 \%$ & 2,557 & 2,684 & $20.2 \%$ & 13,299 \\
\hline
\end{tabular}




\begin{tabular}{|c|c|c|c|c|c|c|c|c|}
\hline \multirow{2}{*}{ 대분류 } & \multirow{2}{*}{ 중분류 } & \multirow{2}{*}{ 소분류 } & \multicolumn{3}{|c|}{ 사업체수 } & \multicolumn{3}{|c|}{ 종사자수 } \\
\hline & & & 관광산업 & 비중 & 전체 & 관광산업 & 비중 & 전체 \\
\hline & \multirow{5}{*}{$\begin{array}{c}\text { 관광및 } \\
\text { 레저용품 } \\
\text { 소매업 }\end{array}$} & 레저용 의복 소매업 & 296 & $1.6 \%$ & 18,004 & 852 & $2.0 \%$ & 43,127 \\
\hline & & 레저 및 스포츠용품 소매업 & & & 2,959 & & & 4,705 \\
\hline & & $\begin{array}{c}\text { 자전거 및 기타 운송장비 } \\
\text { 소매업 }\end{array}$ & 3,449 & $100 \%$ & 3,449 & 5,051 & $100 \%$ & 5,051 \\
\hline & & $\begin{array}{l}\text { 관광용 가방 및 기타 } \\
\text { 가죽제품 소매업 }\end{array}$ & 217 & $99.5 \%$ & 218 & 471 & $99.6 \%$ & 473 \\
\hline & & 소계 & 3,962 & $16.1 \%$ & 24,630 & 6,374 & $11.9 \%$ & 53,356 \\
\hline & \multirow{4}{*}{$\begin{array}{c}\text { 관광보험 } \\
\text { 및 } \\
\text { 금융 } \\
\text { 서비스업 }\end{array}$} & 여행자 보험업 & 2 & $0.1 \%$ & 2,759 & 24 & $0.0 \%$ & 83,125 \\
\hline & & 여행자 수표 발행 & 21 & $77.8 \%$ & 27 & 287 & $85.7 \%$ & 335 \\
\hline & & 환전소 & 488 & $100 \%$ & 488 & 718 & $100 \%$ & 718 \\
\hline & & 소계 & 511 & $15.6 \%$ & 3,274 & 1,029 & $1.2 \%$ & 84,178 \\
\hline & \multirow{7}{*}{$\begin{array}{l}\text { 레저 } \\
\text { 장비업 }\end{array}$} & 사진기 및 사진용품 소매업 & 330 & $100 \%$ & 330 & 739 & $100 \%$ & 739 \\
\hline & & 레저장비 임대업 & 990 & $97.4 \%$ & 1,016 & 3,362 & $98.6 \%$ & 3,411 \\
\hline & & 운송장비 임대업 & 58 & $32.6 \%$ & 178 & 140 & $35.2 \%$ & 398 \\
\hline & & 캠핑카 임대업 & 30 & $96.8 \%$ & 31 & 62 & $98.4 \%$ & 63 \\
\hline & & 관광용 자동차 임대업 & 23 & $60.5 \%$ & 38 & 54 & $27.0 \%$ & 200 \\
\hline & & 일반 자동차 임대업 & 2,837 & $98.7 \%$ & 2,874 & 10,990 & $99.0 \%$ & 11,101 \\
\hline & & 소계 & 4,268 & $95.5 \%$ & 4,467 & 15,347 & $96.4 \%$ & 15,912 \\
\hline \multirow{17}{*}{$\begin{array}{l}\text { 부분 } \\
\text { 적용 } \\
\text { 관광 } \\
\text { 산업 }\end{array}$} & \multirow{2}{*}{$\begin{array}{c}\text { 관광 } \\
\text { 비인증 } \\
\text { 쇼핑업 } \\
\end{array}$} & 관광 비인증 쇼핑업 & 5 & $0.0 \%$ & 116,409 & 22 & $0.0 \%$ & 478,771 \\
\hline & & 소계 & 5 & $0.0 \%$ & 116,409 & 22 & $0.0 \%$ & 478,771 \\
\hline & \multirow{8}{*}{$\begin{array}{l}\text { 부분관광 } \\
\text { 운송업 }\end{array}$} & 도시간 철도 운송업 & 129 & $100 \%$ & 129 & 3,290 & $100 \%$ & 3,290 \\
\hline & & 도시내 철도 운송업 & 784 & $99.7 \%$ & 786 & 15,864 & $97.4 \%$ & 16,293 \\
\hline & & 관광보조 버스 운송업 & 20 & $40.8 \%$ & 49 & 992 & $91.3 \%$ & 1,087 \\
\hline & & 시내외버스 운송업 & 3 & $0.7 \%$ & 413 & 696 & $3.7 \%$ & 18,580 \\
\hline & & 택시 운송업 & . & & 3,910 & . & & 5,336 \\
\hline & & 수상운송업 & 108 & $100 \%$ & 108 & 648 & $100 \%$ & 648 \\
\hline & & 내항-내륙 여객선 운송업 & 94 & $100 \%$ & 94 & 1,376 & $100 \%$ & 1,376 \\
\hline & & 소계 & 1,138 & $20.7 \%$ & 5,489 & 22,866 & $49.1 \%$ & 46,610 \\
\hline & \multirow{3}{*}{$\begin{array}{c}\text { 부분 } \\
\text { 관광 } \\
\text { 숙박업 }\end{array}$} & 청소년수련원 & 507 & $100 \%$ & 507 & 8,266 & $100 \%$ & 8,266 \\
\hline & & 관광 비인증 모텔업 & 15,097 & $85.1 \%$ & 17,739 & 33,019 & $83.7 \%$ & 39,429 \\
\hline & & 소계 & 15,604 & $85.5 \%$ & 18,246 & 41,285 & $86.6 \%$ & 47,695 \\
\hline & \multirow{4}{*}{$\begin{array}{c}\text { 부분관광 } \\
\text { 음식점 } \\
\text { 및 } \\
\text { 주점업 }\end{array}$} & 관광 일반음식점업 & 1 & $0.0 \%$ & 348,878 & 10 & $0.0 \%$ & $1,029,571$ \\
\hline & & 비알콜 관광 음료점업 & 50 & $76.9 \%$ & 65 & 424 & $31.8 \%$ & 1,335 \\
\hline & & 기타 관광 주점업 & 77,342 & $88.9 \%$ & 86,968 & 159,382 & $86.9 \%$ & 183,315 \\
\hline & & 소계 & 77,393 & $17.8 \%$ & 435,911 & 159,816 & $13.2 \%$ & $1,214,221$ \\
\hline
\end{tabular}




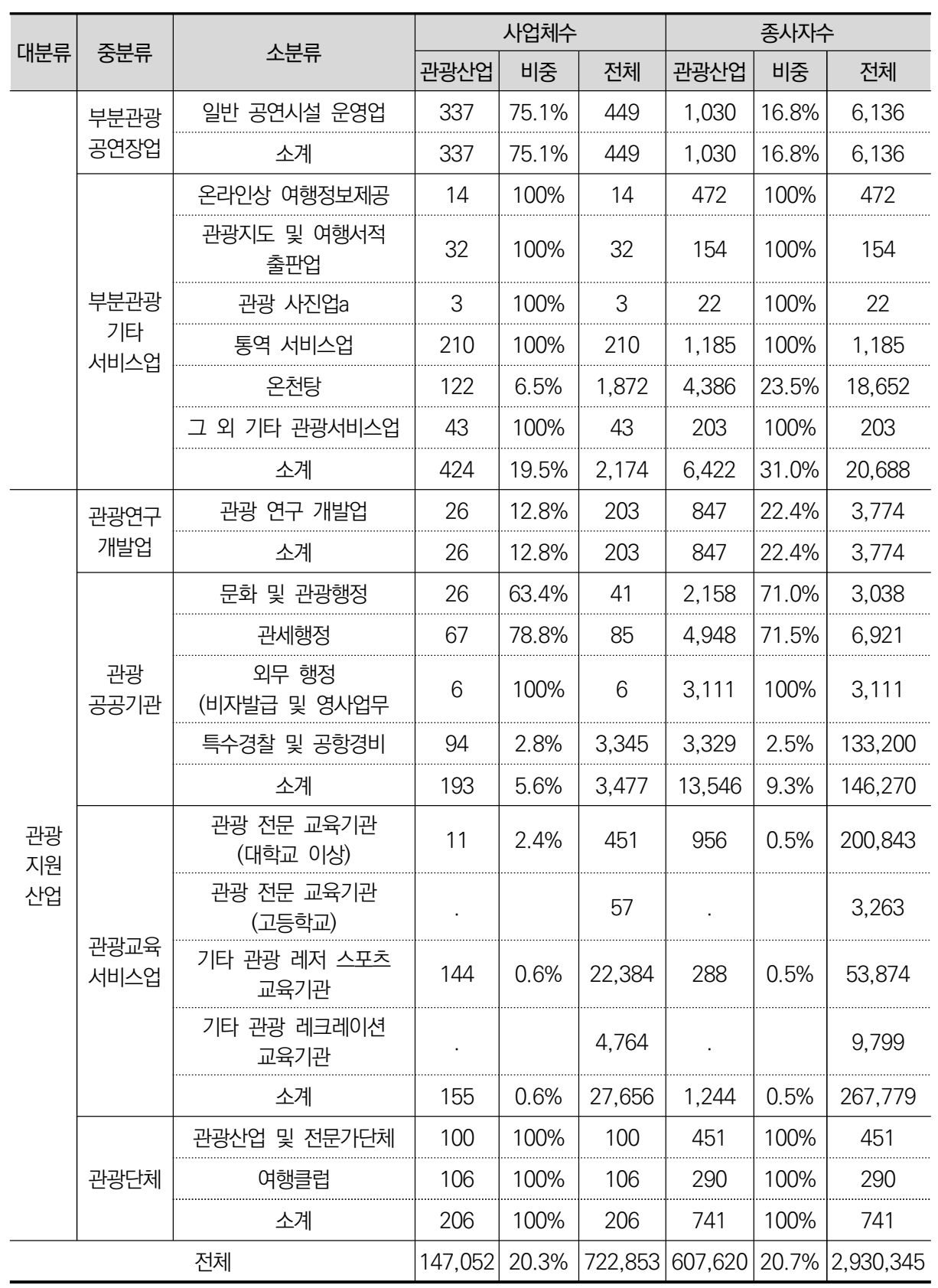

※ 비중: 전체 사업체 중에서 품목분석을 통해 관광산업으로 식별되는 사업체의 비중 

관광산업특수분류 개정안에 기초한 관광산업통계 생산방안 연구

제5장 결론 및 제언 



\section{제1절 결론}

\section{1. 기존 관광산업 분류 및 통계의 한계}

국가 및 세계 경제에서 차지하는 관광산업의 중요성이 증대되면서 다양한 관광산 업 육성 정책이 추진되고 있다. 한정된 예산과 인력을 투입하여 관광산업의 정책효 과를 극대화하기 위해서는 정책 대상인 관광산업의 범위가 명확해야 할 것이다. 하 지만 최근 관광활동의 범위 확대 및 트렌드가 변화되면서 관광산업의 범위 또한 기 존의 전통적인 산업을 넘어 점차 확대되고 있다. 특히 다양한 영역간 융·복합이 강 조되면서 관광분야와 타 분야간의 융·복합 현상도 증가하는 등 관광산업의 범위는 확대됨과 동시에 더욱 모호해 지고 있다.

이러한 상황 속에서 기존 관광산업 분류는 몇몇 한계를 갖고 있다.

첫째, 관광산업의 범위를 과소 추정했을 가능성이 매우 크다. 그동안 관광산업 정 책 및 관광산업 통계(예: 관광사업체통계) 등의 주요 대상은 관광진흥법에서 규정하 고 있는 관광사업체였다. 관광진흥법에서 규정하고 있는 관광산업은 관광활동과 관 련성이 높은 영역을 중심으로 구성되어 있는데 관광활동과 직·간접적 관련성이 있 으나 누락된 영역이 존재한다. 그 결과 문화체육관광부 등 관광정책 수립의 주체들 이 추진하고 있는 관광산업의 정책대상 역시 현실적인 관광산업을 충분히 반영하고 있지 못하다. 관광산업은 여행업을 비롯하여 숙박, 교통, 식음, 문화오락, 쇼핑 등 다양한 산업영역이 복잡하게 연계되어 있는 특성을 갖는다. 따라서 바람직한 관광 산업 육성 정책을 추진하기 위해서는 관광활동과 관련 있는 다양한 영역을 종합적 으로 고려한 정책의 마련 및 추진이 필요하다. 하지만 관광산업 정책의 대상이 관광 활동과 관련성 높은 영역에 한정되다 보니 관광산업 정책의 확장 등에 한계가 존재 하는 상황이다. 나아가 상호 협력해야 할 산업영역에서의 정책들이 서로 엇박자를 보이는 문제가 발생할 가능성도 있다. 
둘째, 관광산업특수분류의 한계가 존재한다. 앞서 언급한 관광산업의 과소 추정 문제를 완화하고 보다 실제에 가까운 관광산업의 범위를 설정하기 위하여 관광산업 특수분류 체계를 마련하여 활용하고 있다. 관광산업특수분류는 세계관광기구 (WTO; World Tourism Organization)와 유엔통계위원회가 공동으로 작성한 국 제관광표준분류(Standard International Classification of Tourism Activities) 를 기초로 2000년에 최초 제정되었으며, 2차 개정까지 이루어졌다.

관광산업의 범위가 관광진흥법상 관광산업 중심으로 설정되어 과소 추정되는 한 계를 보완하고 보다 현실적인 관광산업의 범위를 설정하기 위해 마련된 관광산업특 수분류는 오히려 관광산업의 범위를 과대 추정할 가능성이 높다는 한계를 갖고 있 다. 다양한 산업 중 일반적으로 관광활동과 관련성이 있는 산업을 관광산업특수분 류에 포함하다 보니 관광활동과 밀접한 관련성이 없는 경제활동까지 포함하게 되는 것이다. 예를 들어 '음식점업'을 관광산업특수분류에 포함하게 되면 관광활동과 관 련 없는 일상적인 음식점 소비활동도 관광산업에 포함되며 그 결과 관광산업의 범 위가 과대 추정되는 문제가 발생되는 것이다. 이러한 이유로 인해서 관광산업특수 분류는 마련되어 있으나 아직까지도 활용도는 낮은 상황이다.

관광활동의 범위가 확장되고 다양화 되면서 관광산업 범위도 점차적으로 확장되 고 있다. 하지만 현재의 관광산업 범위를 규정할 수 있는 분류체계(관광진흥법상 분 류체계, 관광산업특수분류체계)는 실제 관광산업을 과소추정하거나 과대 추정할 가 능성이 높은 상황이다. 이에 실제 관광산업의 규모를 보다 정확하게 반영할 수 있도 록 관광산업 분류를 개선하는 노력이 필요하다. 뿐만 아니라 개정된 관광산업 분류 체계를 활용하여 관광산업 규모와 같은 기초적인 통계를 생산하는 등 관광산업 정 책의 대상을 명확히 하고 종합적인 관점에서 관광산업을 육성시킬 수 있는 정책을 마련할 필요가 있겠다.

\section{2. 관광산업특수분류 개정}

본 연구에서는 기존 관광산업특수분류에 대한 개정을 크게 두 가지 관점에서 접 근하였다. 
첫째는 관광산업적 관점에서의 접근이다. 관광산업 환경 변화, 관광진흥법 개정 내용, 한국표준산업분류 10 차 개정 내용, 향후 통계 조사 방안 등을 고려하여 관광 산업특수분류 개정 방안을 도출하였다. 그리고 관광산업특수분류에서 관광진흥법상 의 관광산업을 구별할 수 있도록 구성하였다.

둘째는 분류체계 관점에서의 접근이다. 관광산업특수분류는 활용도를 제고하기 위하여 한국표준산업분류와의 연계성을 확보할 필요가 있다. 관광산업특수분류를 한국표준산업분류와 연계함으로써 국제표준산업분류, 산업연관표와의 연계가 가능 해지며, 관광산업특수분류를 활용한 관광산업 표본틀 갱신시 시의성 있는 표본틀 구축이 가능해진다. 따라서 관광산업특수분류는 한국표준산업분류의 세세분류(5자 리 숫자)와 연계가 가능하도록 한국표준산업분류의 산업 특성 및 세부 품목 분석을 통해 연계표를 작성하였다. 좀 더 구체적으로 살펴보면 한국표준산업분류와의 연계 표 작성시 관광산업특수분류와 한국표준산업분류가 일대일로 연계되는 경우와 그 렇지 않는 경우로 구분하였다. 관광산업특수분류의 분류 구조와 부호 체계는 한국 표준산업분류체계 기준을 준용하였다. 분류구조는 대분류(1자리 숫자 사용), 중분류 (2자리 숫자 사용), 소분류(2자리 숫자 사용), 세분류(2자리 숫자 사용)의 4단계로 구성하여 총 7자리의 코드를 부여하였다. 중분류 이하의 분류는 01부터 99까지를 부여하며, 향후 분류가 추가될 것을 고려하여 분류별 사이에 번호 여백을 두었다. 관광산업특수분류 개정을 위해 국내외 사례분석, 전문가 자문회의(1차), 전문가 설문조사(2차) 등을 진행하였다. 관광산업특수분류 개정 과정을 좀 더 구체적으로 살펴보면 우선 국내외 사례분석을 통해 관광산업특수분류 1 차 개정(안)을 도출하였 다. 이때는 현재의 관광산업특수분류의 핵심관광산업을 토대로 관광진흥법상의 관 광산업분류와 관광위성계정 권고안(TSA: RMF 2008)의 관광상품분류 등을 함께 비교·분석하였다. 둘째, 1 차 개정(안)에 대해 전문가 자문회의를 실시하고 1 차 개정 (안)을 수정·보완한 2차 개정(안)을 도출하였다. 셋째, 관광산업분류, 관광산업 파급 효과 분석 등과 관련한 전문가들을 대상으로 2 차에 걸친 전문가 의견조사를 실시하 였으며 조사결과 바탕으로 관광산업특수분류 개정에 대한 타당도 및 신뢰도를 검증 하였다. 마지막으로 실제 관광산업특수분류 개정에 관여하는 통계청의 의견수렴을 통해 최종 관광산업특수분류 개정(안)을 확정하였다. 
〈표 5-1〉 관광산업특수분류 개정 절차

\begin{tabular}{|c|c|c|}
\hline & 구분 & 내용 \\
\hline \multicolumn{2}{|c|}{ 관광산업특수분류 개정(안) 도출 } & 국내외 사례분석을 통해 관광산업특수분류 1차 개정(안) 도출 \\
\hline \multicolumn{2}{|c|}{ 1차 전문가 자문회의 } & $\begin{array}{l}1 \text { 차 개정(안)을 기준으로 전문가 자문회의 실시 } \\
1 \text { 차 개저(아)으 스저.보와하 2 차 개저(아) 도츠 }\end{array}$ \\
\hline \multirow{4}{*}{ 델파이 조사 } & 사전 준비 & 델파이 조사 전문가 패널 선정 \\
\hline & 1차 델파이 조사 & $\begin{array}{l}2 \text { 차 개정(안)을 기준으로 델파이 조사 진행 } \\
2 \text { 차 개정(안)을 수정·보완한 } 3 \text { 차 개정(안) 도출 }\end{array}$ \\
\hline & 2차 델파이 조사 & 3차 개정(안)을 기준으로 델파이 조사 진행 \\
\hline & 타당도 및 신뢰도 검증 & 도출된 분류에 대한 타당도 및 신뢰도 검증 \\
\hline \multicolumn{2}{|c|}{ 2차 전문가 자문회의(예정) } & $\begin{array}{l}\text { 관광산업특수분류 개정(안) 최종 수정·보완 } \\
\text { 통계청 기준과 의견 수렴 }\end{array}$ \\
\hline \multicolumn{2}{|c|}{ 관광산업특수분류 개정(안) 마련 } & 최종 관광산업특수분류 개정(안) 도출 및 개정 \\
\hline
\end{tabular}

개정된 관광산업특수분류는 기존 분류체계와 동일하게 관광산업을 핵심관광산 업, 상호의존 관광산업, 부분적용 관광산업, 관광 지원산업으로 구분하고 있다. 핵 심 관광산업은 전적으로 관광객에 의존하는 산업으로 주로 관광진흥법에서 규정한 관광산업을 포함하고 있다. 구체적으로는 관광 쇼핑업, 관광 운수업, 관광 숙박업, 관광 음식점 및 주점업, 여행사 및 여행보조 서비스업, 국제회의업, 문화·오락 및 레저 스포츠산업, 카지노업 등이 해당한다. 상호의존 관광산업은 원래 관광산업은 아니지만 핵심 관광산업을 보조하기 위해 동반되는 산업으로 관광 건설업, 관광 및 레저용품 소매업, 관광 금융 및 보험업, 레저장비업 등을 포함한다. 부분적용 관광 산업은 부분적으로 관광객에 의존하는 산업으로 관광 비인증 쇼핑업, 부분관광 운 송업, 부분관광 숙박업, 부분관광 음식점 및 주점업, 부분관광 공연장업, 부분관광 기타 서비스업 등을 포함하고 있다. 마지막으로 관광 지원산업은 관광산업을 지원 하기 위한 부문으로 관광관련 관광 연구개발업, 관광 공공기관, 관광 교육서비스업, 관광단체 등을 포함하고 있다. 
〈표 5-2〉 관광산업특수분류 상 세부 관광산업 분류

\begin{tabular}{|c|c|}
\hline 구분 & 정의 \\
\hline $\begin{array}{l}\text { 핵심 } \\
\text { 관광산업 }\end{array}$ & $\begin{array}{l}\text { 전적으로 관광객에 의존하는 산업으로 관광 쇼핑업, 관광 운수업, 관광 숙박업, 관광 음식점 } \\
\text { 및 주점업, 여행사 및 여행보조 서비스업, 국제회의업, 문화·오락 및 레저 스포츠산업, 카지노 } \\
\text { 업을 포함하며, 주로 관광진흥법에서 규정한 관광산업을 포함함 }\end{array}$ \\
\hline $\begin{array}{l}\text { 상호의존 } \\
\text { 관광산업 }\end{array}$ & $\begin{array}{l}\text { 원래 관광산업은 아니지만 핵심 관광산업을 보조하기 위해 동반되는 산업으로 관광 건설업, } \\
\text { 관광 및 레저용품 소매업, 관광 금융 및 보험업, 레저장비업을 포함함 }\end{array}$ \\
\hline $\begin{array}{l}\text { 부분적용 } \\
\text { 관광산업 }\end{array}$ & $\begin{array}{l}\text { 부분적으로 관광객에 의존하는 산업으로 관광 비인증 쇼핑업, 부분관광 운송업, 부분관광 숙 } \\
\text { 박업, 부분관광 음식점 및 주점업, 부분관광 공연장업, 부분관광 기타 서비스업을 포함함 }\end{array}$ \\
\hline $\begin{array}{l}\text { 관광 } \\
\text { 지원산업 }\end{array}$ & $\begin{array}{l}\text { 관광산업을 지원하기 위한 부문으로 관광관련 관광 연구 개발업, 관광 공공기관, 관광 교육서 } \\
\text { 비스업, 관광단체를 포함함 }\end{array}$ \\
\hline
\end{tabular}

개정된 관광산업특수분류는 다음과 같다. 핵심 관광산업은 면세업, 관광 쇼핑업 (도매업 제외), 관광운수업, 관광숙박업, 관광휴양업, 관광 음식점 및 주점업, 여행 사 및 여행 보조 서비스업, 국제회의업, 문화, 오락 및 레저 스포츠산업, 카지노업 등 기존 8 개의 중분류 산업에서 10 개 중분류로 세분된다. 상호의존 관광산업은 관 광 건설업, 관광 및 레저용품 소매업, 관광 보험 및 금융서비스업, 레저장비업 등 4 개 중분류 산업으로 세분되며, 부분적용 관광산업은 관광 비인증 쇼핑업, 부분관 광 운송업, 부분관광 숙박업, 부분관광 음식점 및 주점업, 부분관광 공연장업, 부분 관광 기타 서비스업 등 6 개 중분류 산업으로 세분된다. 마지막으로 관광 지원산업 은 관광 연구 개발업, 관광 공공기관, 관광 교육서비스업, 관광 단체 등 4 개 중분류 산업으로 세분된다. 각 중분류 산업에는 소분류 및 세분류 산업들로 다시 세분화되 는 구조이다. 본 연구에서는 아래의 〈표 5-3〉과 같이 관광산업특수분류 3차 개정안 을 재구성하였다. 상호의존 관광산업에서 핵심관광산업으로의 이동이 검토된 '여행 자 보험업, '캠핑카 임대업', '관광용 자동차 임대업'과 부분 관광산업에서 '온라인 상 여행정보제공' 업종의 경우 최종 이동확정이 결정된 이후 핵심관광산업의 중분 류와 소분류상의 적용 기준에 대한 검토가 필요하다. 특히나 타 대분류에서 이동된 업종의 경우 관광관련 비중이 높지 않을 수 있기 때문에 이 부분을 보완할 관광비 (Tourism Ratio)조사 등 별도의 방안을 강구해야 할 것이다. 
〈표 5-3〉 관광산업특수분류 핵심관광산업 3차 개정(안)

\begin{tabular}{|c|c|c|}
\hline 대분류 & 중분류 & 세분류 \\
\hline \multirow{10}{*}{$\begin{array}{l}\text { 핵심 } \\
\text { 관광산업 }\end{array}$} & 면세업 & 관광면세점, 일반면세점, \\
\hline & $\begin{array}{l}\text { 관광 쇼핑업 } \\
\text { (도매업 제외) }\end{array}$ & 관광기념품 판매업 \\
\hline & 관광운수업 & $\begin{array}{l}\text { 철도여객운송업, 시내순환 관광업, 전세버스 운송업, 관광궤도업, } \\
\text { 관광유람선업, 크루즈업, 항공여객운송업 }\end{array}$ \\
\hline & 관광숙박업 & $\begin{array}{l}\text { 관광호텔업, 수상관광호텔업, 한국전통호텔업, 가족호텔업, } \\
\text { 소형호텔업, 의료관광호텔업, 호스텔업, 휴양콘도미니엄업, } \\
\text { 관광펜션업, 산림휴양림업, 게스트하우스, 레지던스 호텔, 민박업, } \\
\text { 외국인 관광도시 민박업, 자동차 야영장업, 일반 야영장업, } \\
\text { 안옥체험업, 기타 관광숙박시설 운영업 }\end{array}$ \\
\hline & 관광휴양업 & 전문휴양업, 일반휴양업 \\
\hline & 관광 음식점 및 주점업 & $\begin{array}{l}\text { 관광식당업, 관광유흥음식점업, 관광 극장유흥업, 관광 공연장업, } \\
\text { 외국인전용유흥음식점업, }\end{array}$ \\
\hline & $\begin{array}{c}\text { 여행사 및 여행 보조 } \\
\text { 서비스업 }\end{array}$ & $\begin{array}{l}\text { 일반여행업, 국외여행업, 국내여행업, 국내외여행업, 여행보조 및 } \\
\text { 예약 서비스업, 관광사진업 }\end{array}$ \\
\hline & 국제회의업 & 국제회의 기획업, 국제회의 시설업 \\
\hline & $\begin{array}{c}\text { 문화, 오락 및 레저 } \\
\text { 스포츠산업 }\end{array}$ & $\begin{array}{l}\text { 박물관 및 사적지 관리 운영업, 식물원/동물원 및 자연공원 운영업, } \\
\text { 유원시설업, 농어촌 체험 및 생태 관광업, 관광 공연장업, 관광 레저 } \\
\text { 스포츠시설 운영업, 기타 분류 안 된 오락 관련 서비스업 }\end{array}$ \\
\hline & 카지노업 & 외국인 전용 카지노업, 내국인 출입 카지노업 \\
\hline
\end{tabular}

\section{3. 관광산업통계 생산 방안}

관광산업특수분류를 개정한 핵심 목적은 보다 현실적인 관광산업을 분류하고 그 규모 등을 파악하는데 활용하기 위함이다. 그동안 관광사업체조사 등 주요 관광산 업 통계는 대부분 관광진흥법에서 규정하고 있는 관광사업체를 중심으로 생산되었 다. 이러한 방법은 모집단이 명확하다는 장점이 있지만 전체 관광산업의 규모와 특 성을 파악하는데 한계가 있었다. 이에 본 연구에서는 개정된 관광산업특수분류를 활용하여 관광산업통계를 보다 현실적으로 생산하는 방안에 대한 검토를 실시하였 다. 주요 내용은 관광산업 통계 생산을 위한 표본 설계(모집단 설정, 적정 표본 크기 결정, 표본 층화), 모수 추정(모수 추정식, 가중치, 무응답 대체) 등이다. 다만 개정 
된 관광산업특수분류 역시 앞으로 지속적인 보완이 필요하며, 이번 연구에서 검토 한 관광산업통계 생산방안 역시 즉각 적용하여 도출하기 보다는 시범조사 등의 단 계별 점검 및 개선과정을 거쳐 안정적인 도입을 검토해야 할 것이다.

관광산업특수분류 체계를 활용한 관광산업통계의 목표 모집단은 전국 17 개 지방 자치단체에서 관광산업특수분류 코드가 적용되는 모든 사업체가 된다. 통계 조사를 위한 조사 모집단은 『전국사업체조사』결과 중에서 주사업과 부사업 중에서 관광산 업과 관광산업특수분류를 하나라도 영위하는 모든 사업체가 된다. 관광산업특수분 류 개정안에 따라 관광산업통계를 생산하기 위한 단계별 조사모집단을 구분해 보면 다음과 같다.

- 1 단계: 관광산업특수분류 > 핵심관광산업 > 'a' 코드 기준 (단, 부분적용산업의 3 개 사업체 포함)

- 2단계: 관광산업특수분류 > 핵심관광산업 전체 사업체

- 3단계: 관광산업특수분류 > 품목분석 구분 사업체

- 4단계: 관광산업특수분류 > 전체 사업체

각 단계별 모집단 사업체의 현황을 도식화하면 다음과 같다.

[그림 5-1] 관광산업의 단계별 조사모집단 구성

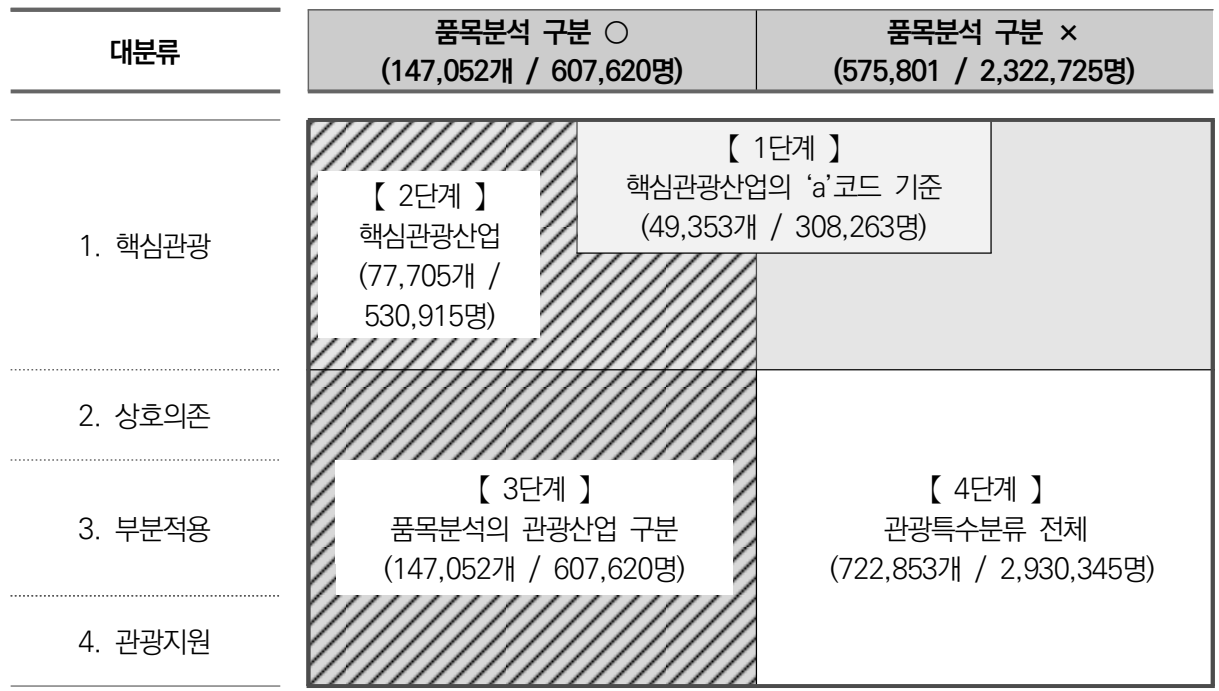


관광산업의 단계별 조사 모집단 현황을 살펴보면 관광산업특수분류 > 핵심관광산 업 > 'a' 코드 기준(1단계) 수는 총 49,353개소, 관광산업특수분류 상 핵심관광산업 (2단계) 수는 총 77,705 개소이다. 관광산업특수분류 상 관광산업 품목분석 구분 사 업체(3단계) 수는 총 147,052 개소이며, 관광산업특수분류 전체사업체(4단계) 수는 총 722,853 개소이다.

〈표 5-4〉 모집단 사업체 수 현황

(단위: 개소)

\begin{tabular}{|c|c|c|}
\hline 구분 & 모집단 수 & 세부 내용 \\
\hline $\begin{array}{c}\text { 관광산업특수분류 > } \\
\text { 핵심관광산업 > 'a' 코드 기준 } \\
\text { (1단계) }\end{array}$ & 49,353 & 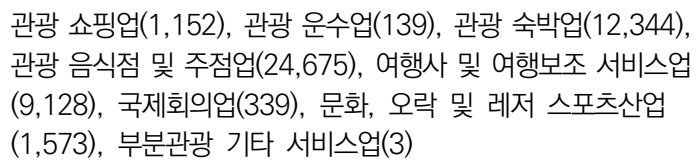 \\
\hline $\begin{array}{c}\text { 관광산업특수분류 > } \\
\text { 핵심관광산업 전체 사업체 } \\
\text { (2단계) }\end{array}$ & 77,705 & $\begin{array}{l}\text { 관광 쇼핑업(1,483), 관광 운수업(1,563), 관광 숙박업 } \\
\text { (31,609), 관광 음식점 및 주점업(24,675), 여행사 및 } \\
\text { 여행보조 서비스업(10,099), 국제회의업(339), } \\
\text { 문화, 오락 및 레저 스포츠산업(7,921), 카지노업(16) }\end{array}$ \\
\hline $\begin{array}{l}\text { 관광산업특수분류 > } \\
\text { 품목분석 구분 사업체 } \\
\text { (3단계) }\end{array}$ & 147,052 & $\begin{array}{l}\text { 핵심 관광산업(42,638), 상호의존 관광산업(8,933), 부분적용 } \\
\text { 관광산업(94,901), 관광 지원산업( } 580)\end{array}$ \\
\hline $\begin{array}{l}\text { 관광산업특수분류 } \\
\text { 전체 사업체 } \\
\text { (4단계) }\end{array}$ & 722,853 & $\begin{array}{l}\text { 핵심 관광산업(77,705), 상호의존 관광산업(34,928), 부분적용 } \\
\text { 관광산업(578,678), 관광 지원산업(31,542) }\end{array}$ \\
\hline
\end{tabular}

본 연구에서는 관광산업특수분류 > 핵심관광산업 > 관광진흥법상 관광사업체에 해당되는 'a' 업종과 실제 관광사업체조사에 포함된 동일한 업종명의 사업체 수를 비교분석하여 데이터 활용성을 검토하였다. 분석결과 관광산업특수분류 핵심관광산 업에서 ' $\mathrm{a}$ '코드를 부여받은 업종과 실제 관광사업체조사의 동일 업종 간에는 많은 차이가 있는 것으로 나타났다. 관광산업특수분류에 사용된 모집단이 2017년 전국 사업체조사이며 관광사업체조사에 사용된 모집단이 2018년 기준 모집단임에 따라 발생되는 시차의 차이를 감안하더라도 ' $a$ '코드를 부여받은 핵심관광산업을 관광진 흥법상 관광사업체로 가정하여 분석하기에는 무리가 있다. 이에 기존조사의 시계열 적 연장과 확대된 차원에서의 관광산업통계 조사를 위해서는 2 개의 모집단 구성 및 차별화된 분석방법 마련이 필요할 것으로 판단된다. 
〈표 5-5〉 관광진흥법 관광사업체 VS 관광산업특수분류 핵심산업 ' $a$ '코드

\begin{tabular}{|c|c|c|c|c|c|}
\hline \multicolumn{3}{|c|}{ 관광진흥법 관광사업체 } & \multirow{2}{*}{ 모집단 } & \multirow{2}{*}{$\begin{array}{c}\text { 관광산업특수분류 } \\
\text { (핵심산업) }\end{array}$} & \multirow{2}{*}{ 모집단 } \\
\hline 대분류 & 중분류 & 소분류 & & & \\
\hline \multirow{4}{*}{ 여행업 } & 일반여행업 & & 5,738 & 일반 여행업a & 7,578 \\
\hline & 국외여행업 & & 5,544 & 국외 여행업a & 837 \\
\hline & 국내여행업 & . & 2,640 & 국내 여행업a & 713 \\
\hline & 국내외여행업 & & 5,117 & & \\
\hline \multirow{8}{*}{$\begin{array}{l}\text { 관광 } \\
\text { 숙박업 }\end{array}$} & \multirow{7}{*}{ 호텔업 } & 관광호텔업 & 1,043 & 관광 호텔업a & 817 \\
\hline & & 수상관광호텔업 & - & 수상관광 호텔업a & \\
\hline & & 한국전통호텔업 & 9 & 한국전통 호텔업a & \\
\hline & & 가족호텔업 & 160 & 가족 호텔업a & 10 \\
\hline & & 호스텔업 & 638 & 호스텔업a & 159 \\
\hline & & 소형호텔업 & 33 & & \\
\hline & & 의료관광호텔업 & - & & \\
\hline & 휴양콘도 미니엄업 & & 227 & 휴양콘도미니엄업a & 311 \\
\hline \multirow{7}{*}{$\begin{array}{c}\text { 관광객이용 } \\
\text { 시설업 }\end{array}$} & 전문휴양업 & & 99 & & \\
\hline & 종합휴양업 & & 34 & & \\
\hline & \multirow{2}{*}{ 야영장업 } & 일반야영장업 & 1,910 & & \\
\hline & & 자동차야영장업 & 426 & 자동차야영장업a & 860 \\
\hline & 관광유람선업 & & 48 & 관광 유람선업a & 100 \\
\hline & 관광공연장업 & & 7 & 관광공연시설 운영업 & 110 \\
\hline & $\begin{array}{l}\text { 외국인관광 } \\
\text { 도시민박업 }\end{array}$ & & 1,799 & $\begin{array}{l}\text { 외국인 관광 } \\
\text { 도시민박업a }\end{array}$ & 23 \\
\hline \multirow{2}{*}{ 국제회의업 } & 국제회의시설업 & . & 13 & 국제회의시설업a & 2 \\
\hline & 국제회의기획업 & & 873 & 국제회의기획업 $a$ & 337 \\
\hline 카지노업 & & & 17 & 카지노업a & 16 \\
\hline \multirow{3}{*}{$\begin{array}{l}\text { 유원 } \\
\text { 시설업 }\end{array}$} & 종합유원시설업 & & 49 & 종합유원시설업a & 32 \\
\hline & 일반유원시설업 & & 416 & 일반유원시설업a & 206 \\
\hline & 기타유원시설업 & & 2,535 & 기타유원시설업a & 1,335 \\
\hline \multirow{6}{*}{$\begin{array}{c}\text { 관광 } \\
\text { 편의 } \\
\text { 시설업 }\end{array}$} & 관광유흥 음식점업 & & 10 & 관광유흥 음식점업a & 9,489 \\
\hline & 관광극장유흥업 & & 110 & 관광극장유흥업a & 103 \\
\hline & $\begin{array}{c}\text { 외국인전용 } \\
\text { 유흥음식점업 }\end{array}$ & & 358 & $\begin{array}{c}\text { 외국인전용 } \\
\text { 유흥음식점업a }\end{array}$ & 329 \\
\hline & 관광식당업 & & 1,617 & 관광 식당업a & 14,707 \\
\hline & 관광순환버스업 & & 58 & 시내순환 관광업a & 2 \\
\hline & 관광사진업 & & 17 & & 3 \\
\hline
\end{tabular}




\begin{tabular}{|c|c|c|c|c|c|}
\hline \multicolumn{3}{|c|}{ 관광진흥법 관광사업체 } & \multirow{2}{*}{ 모집단 } & \multirow{2}{*}{$\begin{array}{l}\text { 관광산업특수분류 } \\
\text { (핵심산업) }\end{array}$} & \multirow{2}{*}{ 모집단 } \\
\hline 대분류 & 중분류 & 소분류 & & & \\
\hline & $\begin{array}{l}\text { 여객자동차 } \\
\text { 터미널시설업 }\end{array}$ & & 2 & & - \\
\hline & 관광펜션업 & . & 564 & 관광펜션업a & 10,035 \\
\hline & 관광궤도업 & 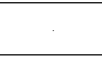 & 16 & 관광궤도업a & 19 \\
\hline & 한옥체험업 & 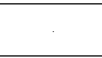 & 1,284 & 한옥체험업a & 152 \\
\hline & 관광면세업 & & 41 & 면세점 & 43 \\
\hline
\end{tabular}

주1: 관광산업특수분류 'a' 코드 사업체는 품목분석을 하지 않은 사업체 수임

주2: 관광공연장업은 관광진흥법상 관광사업체에 포함되지만 관광산업특수분류에서의 핵심산업인 관광공연시설 운영업은 'a'코드를 부여받지 않음

모집단 현황을 확인했다면 그 다음으로 적정 표본크기를 결정하여야 한다. 본 연구 에서는 적정 표본크기 산출을 위해 네이만배분법과 비례배분법을 통해 신뢰수준 $95 \%$ 에서 목표허용오차수준을 목표허용오차 $\pm 1 \% \mathrm{p} \sim 10 \% \mathrm{p}$ 를 기준으로 적정표본수를 산출하였다. 목표허용오차가 $\pm 5 \%$ 일 경우 1 단계(핵심관광산업의 ' $a$ '코드) 사업체는 4,060 개소, 2단계(핵심 관광산업 전체)는 4,917개소, 3 단계(품목분석의 관광산업 구 분) 사업체는 5,474 개소, 4단계(관광특수분류 전체)사업체는 7,003개소의 표본이 요 구되는 것으로 산출되었다. 향후 효율적인 관광산업통계 생산을 위해서는 조사예산 및 조사방법 등과 오차수준을 고려한 보다 현실적인 설정이 필요할 것이다.

〈표 5-6〉네이만배분법에 의한 적정 표본수 산정 결과

\begin{tabular}{c|c|c|c|c}
\hline \multirow{2}{*}{$\begin{array}{c}\text { 상대오차 } \\
\text { 수준 }\end{array}$} & \multicolumn{2}{|c|}{ 핵심 산업 } & \multicolumn{2}{c}{ 전체 산업 } \\
\cline { 2 - 5 } & $\begin{array}{c}\text { 1단계 } \\
\text { 햄심관상업의 } \\
\text { 'a'코드 }\end{array}$ & $\begin{array}{c}\text { 2단계 } \\
\text { 핵심관광산업 전체 }\end{array}$ & $\begin{array}{c}\text { 3단계 } \\
\text { 품목분석의 관광산업 } \\
\text { 구분 }\end{array}$ & $\begin{array}{c}\text { 4단계 } \\
\text { 관광특수분류 전체 }\end{array}$ \\
\hline $1 \%$ & 35,454 & 45,693 & 41,605 & 43,999 \\
\hline $2 \%$ & 15,733 & 17,984 & 15,357 & 15,431 \\
\hline $3 \%$ & 8,601 & 9,759 & 8,983 & 9,879 \\
\hline $4 \%$ & 5,576 & 6,501 & 6,604 & 7,915 \\
\hline $5 \%$ & 4,060 & 4,917 & 5,474 & 7,003 \\
\hline $6 \%$ & 3,204 & 4,035 & 4,853 & 6,506 \\
\hline $7 \%$ & 2,675 & 3,495 & 4,476 & 6,206 \\
\hline $8 \%$ & 2,327 & 3,142 & 4,230 & 6,011 \\
\hline $9 \%$ & 2,086 & 2,899 & 4,061 & 5,878 \\
\hline $10 \%$ & 1,912 & 2,724 & 3,940 & 5,782 \\
\hline
\end{tabular}


모수추정을 위한 조사 기본 가중치는 설계가중치, 무응답 보정 가중치, 사후층화 가중치를 반영하였다. 관광산업으로 식별이 가능한 산업의 비중은 사업체 수 기준 으로 $20.3 \%$ 수준이다. 사업체 수를 기준으로 관광산업특수분류의 대분류별 관광산 업 비율을 살펴보면 핵심 관광산업은 $54.9 \%$, 상호의존 관광산업은 $25.6 \%$, 부분적 용 관광산업은 $16.4 \%$, 관광 지원산업은 $1.8 \%$ 로 분석되었다. 관광산업 비율이 비교 적 높은 산업에 대해서는 표본조사를 통해 추정한 결과에 관광산업 비율을 적용하 여 최종 결과를 추정할 수 있다. 하지만 관광산업 비율이 낮은 산업에 대해서는 추 가 조사를 통한 보완이 필요할 것으로 판단된다. 다만 관광산업 비율에 사용된 품목 분석의 경우 통계청의 전국사업체조사 자료를 바탕으로 연구자들이 what, how, who의 사업체별 응답항목을 확인하여 작성된다. 이렇게 도출된 결과는 전국사업체 조사에서 제공하는 정보의 미흡 및 연구자의 주관적인 생각이 반영되었기 때문에 이 부분에 대한 종합적인 검토는 필요하다. 이를 보완하기 위해 본 연구에서는 조사 기본 가중치와 함께 관광산업 비율(ratio) 가중치 반영을 검토하였으며 기존 품목분 석의 결과를 재검증하기 위한 자료로 활용이 가능할 것으로 판단된다.

마지막으로 무응답 대체 방안은 다음과 같다. 무응답은 단위 무응답과 항목 무응 답으로 구분하여 검토하였다. 단위 무응답은 응답거절 등으로 인하여 모든 항목에 응답이 되지 않은 경우 또는 조사가 이루어졌다 하더라도 총매출액을 포함한 핵심 조사항목을 응답하지 않은 경우 등이 해당된다. 항목 무응답은 대부분의 항목에 응 답하였으나 특정 항목에 응답하지 않은 경우이다. 이처럼 무응답 유형별로 무응답 을 처리하는 절차를 제안하였다. 본 연구에서는 무응답대체 방법론들을 층에 따라 혼용하는 방법을 고려하여 적용하는 방안을 제안하였다. 즉 어떤 층에는 평균 대체 를 사용하고 어떤 층에는 예측평균 매칭 대체를 사용하는 방법을 적용할 수 있다. 또한 항목이 범주형일 경우에는 회귀분석 대신에 판별분석을 사용한다. 대체 방법 의 선택을 위해 과거의 보고된 경험을 참조하거나 모의분석을 통해 가장 적합한 방 법을 찾아야 할 것이다. 


\section{제2절 정책 제언}

국가 및 지역 차원에서 관광산업의 중요성이 강조되면서 다양한 관광산업 정책을 적극적으로 추진하고 있지만 정책 대상이 되는 관광산업의 분류 및 범위 등에 대해 서는 명확한 기준이 마련되어 있지 않은 상황이다. 이러한 한계를 보완하고자 본 연구에서는 관광환경 변화, 관광진흥법 개정, 한국표준산업분류 변화 등을 고려한 관광산업특수분류 개정(안) 도출방안을 마련하였다. 그리고 개정된 관광산업특수분 류를 활용한 관광산업통계 생산가능성을 검토하였다.

관광산업은 태생적으로 다양한 산업 영역이 복잡하게 연계되어 있으며, 관광객과 비관광객을 구분하여 제품과 서비스를 공급하지는 않는다. 즉 매우 다양한 관광관 련 산업들이 관광객과 비관광객 모두에게 동일한 제품과 서비스를 제공하는 특성이 있기 때문에 관광산업을 명확하게 분류하는 것은 매우 어려운 일이다. 특히 내·외국 인들의 관광활동이 다양해지면서 관광과 관련된 새로운 제품과 서비스가 빠르게 등 장하는 현실은 관광산업 분류를 더욱 어렵게 하고 있다.

이러한 어려운 상황 속에서 관광산업 분류를 정비하고 이에 기반을 둔 관광산업 통계생산방안을 마련한 것은 의미 있는 연구라 할 수 있다. 본 연구를 통해서 그동 안 관광산업 분류 및 관광산업통계 생산의 한계를 부분적으로 보완했지만 여전히 해결해야 할 과제들은 많이 남아 있다. 따라서 현실을 보다 잘 반영하여 관광산업을 분류하고 관광산업의 규모를 보다 정확하게 측정하기 위한 노력은 앞으로도 계속되 어야 할 것이다. 본 연구에서는 앞서 제시된 내용을 바탕으로 다음과 같은 정책적 제언을 도출하였다. 


\section{1. 관광산업 분류 관련 제언}

\section{가. 실제 관광산업을 반영할 수 있는 관광산업특수분류 개선 지속 추진}

관광산업의 범위가 확장되고 타 산업과의 경계가 모호해 지는 등 앞으로도 관광 산업의 변화는 지속될 것으로 예상된다. 이러한 변화 등을 고려할 때 관광진흥법에 서 규정하고 있는 미시적인 관광산업보다는 관광산업특수분류를 중심으로 한 거시 적 차원의 관광산업의 범위를 설정하는 것이 바람직할 것으로 판단된다. 이를 위해 서는 관광산업특수분류에 대한 지속적인 보완 및 개선이 뒷받침되어야 한다.

현재 관광산업특수분류에 있어 가장 큰 어려움은 각 산업들과 관광과의 관련 정 도를 객관적으로 판단할 수 있는 기준이 부족하다는 점이다. 예를 들어 쇼핑업을 핵심 관광산업, 상호의존 관광산업, 부분적용 관광산업 중 하나로 분류하고자 할 경 우 이를 결정할 수 있는 객관적인 기준 자료가 미흡한 현실이다. 현재는 관련 분야 전문가들의 의견을 반영하여 분류를 설정하고 있지만 전문가들의 의견도 상이한 경 우가 발생할 수 있다. 각 산업과 관광과의 관련 정도를 확인할 수 있는 객관적인 기준 자료가 미흡하기 때문에 동일한 제품 또는 서비스를 제공하는 업종들이 관광 산업특수분류상 여러 대분류로 분할되는 경우도 있다. 쇼핑업의 경우 기존 2 차 개 정에서는 관광인증을 받은 시설은 "핵심 관광산업 - 관광쇼핑업 - 관광인증 쇼핑업" 으로 분류되었으며 관광인증을 받지 않은 시설은 "부분적용 관광산업 - 관광비인증 쇼핑업”으로 분류되었다. 관광인증은 사업자가 선택적으로 신청하면 정부 등에서 평가한 후 일정한 기준에 부합되면 부여받는 조건이다. 이러한 인증은 일정 기간(1 년, 2년 등)이 지나면 효력이 종료되며, 효력 종료시 인증을 재신청하지 않으면 인 증시설이 비인증 시설이 되는 상황이다. 즉 그 사업체가 생산 및 공급하는 제품이나 서비스는 변함이 없는데 인증 여부에 따라 관광산업특수분류에서 대분류 등이 조정 될 수 있다. 만약 여러 대형 쇼핑시설들이 인증 기간이 종료되었으나 재인증을 신청 하지 않을 경우 핵심 관광산업의 쇼핑업 매출액은 감소하는 대신 부분적용 관광산 업의 쇼핑업 매출액은 증가할 것이다. 이러한 결과를 두고 핵심 관광산업 중 쇼핑업 의 매출이 감소했다고 해석한다면 이는 현실을 왜곡하는 큰 문제가 될 수 있다. 실 제 쇼핑업 경제활동의 성장 또는 침체가 아니라 단순히 인증 여부 변동에 따라 결과 
가 변화하는 문제가 발생할 수 있는 것이다.

이에 본 연구에서는 관광산업특수분류에서 인증과 관련된 업종은 핵심관광산업 에서 제외하는 방안을 제시하였다. 다른 예로 식음료업을 살펴보면 관광식당업, 관 광주점업은 핵심 관광산업이며, 부분관광 음식점업, 부분관광 주점업은 부분적용 관광산업으로 분류된다. 음식점 중 관광진흥법에 근거하여 관광식당업으로 지정받 은 경우 핵심 관광산업으로 분류하고 있으나 실제 관광진흥법에 등록된 관광식당업 은 18 년 기준 1,617 개인 반면 관광산업특수분류 핵심산업에 포함된 관광식당업은 14,693 으로 거의 10 배 정도의 차이가 발생된다.

이러한 이유는 관광산업특수분류에 포함된 관광식당업은 한국표준산업분류 상 ‘한식 음식점업’과 ‘외국인 음식점업’을 모두 포괄하고 있기 때문이다. 관광진흥법 에서는 관광식당업을 식품위생 법령에 따른 일반음식점 영업의 허가를 받은 자가 관광객이 이용하기 적합한 음식 제공시설을 갖추고 관광객에게 특정 국가의 음식을 전문적으로 제공하는 업으로 정의하고 있다.

관광식당업의 지정 기준24)은 조리관련 인적 요건, 외국어 병기 메뉴판 구비, 화 장실 시설 등이다. 따라서 관광객의 이용이 많지 않더라도 관광식당업으로 지정받 아 핵심 관광산업으로 분류될 수 있는 상황이다. 반면 관광객의 이용 비중이 높으나 관광식당업으로 지정받지 않은 경우에는 부분적용 관광산업으로 분류된다. 이처럼 실제 관광객의 이용 수준과 상관없이 관광산업특수분류의 대분류가 결정될 가능성 도 존재한다. 이러한 한계를 보완하기 위해서는 각 산업영역에서 관광의 비중이 차 지하는 비율(ratio)을 파악하는 것이 필요하다. 이와 관련해서는 이후에 좀 더 자세 하게 논의하고자 한다.

한편 관광산업 통계조사 등에 있어 관광산업특수분류 활용도를 제고하기 위해서 도 관광산업특수분류의 분류 기준을 지속적으로 정비할 필요가 있다. 관광산업특수 분류를 활용하여 관광산업 통계조사를 실시하고자 할 경우 관광산업특수분류를 근

24) 관광진흥법 시행규칙 별표 2에서 규정하고 있는 관광식당업의 지정 기준은 한국 전통음식을 제공하는 경우에는 「국가기술자격법」에 따른 해당 조리사 자격증 소지자를 둘 것, 특정 외국의 전문음식을 제공하 는 경우에는 3 개 요건(해당 외국에서 전문조리사 자격을 취득한 자, 「국가기술자격법」에 따른 해당 조리 사 자격증 소지자로서 해당 분야에서의 조리경력이 3년 이상인 자, 해당 외국에서 6 개월 이상의 조리교육 을 이수한 자) 중 1 개 이상의 요건을 갖춘 자를 둘 것, 최소 한 개 이상의 외국어로 음식의 이름과 관련 정보가 병기된 메뉴판을 갖추고 있을 것, 출입구가 각각 구분된 남·녀 화장실을 갖출 것 등이다 
거로 모집단을 설정하고 모집단 명부 등을 작성하여야 한다.

모집단 명부를 활용하기 위해서는 두 가지 방안이 있다. 첫 번째는 기존에 통계청 에서 작성한 전국사업체조사의 모집단 명부를 활용하는 방법이다. 다만 통계청 모 집단 자료를 활용할 경우 조사시기와 약 2 년 정도의 시간적 차이가 발생되어 현실 적인 모집단 명부로 보이는 어려울 수 있다. 두 번째는 지방행정인허가 데이터 (LOCAL DATA)를 기반으로 지자체와 협회 등 관련 업종 관리주체를 통해 모집단 명부를 작성하는 방법이다.

모집단 명부 작성 등을 위해서는 지자체 등 사업 등록 및 관리 주체들이 각 사업 체에 대한 기초 정보 등을 체계적으로 관리하고 있어야 한다. 하지만 현재의 관광산 업특수분류를 기반으로 조사 모집단을 확정하고 모집단 명부 등을 작성하기 위해서 는 여러 기관으로부터 사업체 정보를 확보하여 정리해야 하는 상황이다.

앞서 언급했던 것과 같이 쇼핑업의 경우 관광인증을 받은 시설은 "핵심 관광산업 - 관광쇼핑업 - 관광인증 쇼핑업” 으로, 관광인증을 받지 않은 시설은 “부분적용 관 광산업 - 관광비인증 쇼핑업” 으로 분류된다. 이해를 위해 쇼핑업 중 쇼핑센터(근거 법: 유통산업발전법)를 예로 설명해 보겠다.

쇼핑센터는 유통산업발전법에 근거하여 기초지자체(특별자치시장·시장·군수·구 청장)에 등록하여야 한다. 따라서 쇼핑센터에 대한 기초적인 정보는 기초지자체가 관리하게 된다. 한편 그 쇼핑센터에 대한 관광인증 사업은 주로 중앙 정부 또는 광 역지자체가 실시한다. 기초지자체가 실시한다 하더라도 문화관광 관련부서에서 실 시하게 된다. 따라서 특정 쇼핑센터에 대한 사업 등록 정보는 기초지자체에서 확인 하고 그 쇼핑센터가 관광인증을 받았는지는 다른 기관 또는 기초지자체 내 다른 부 서에서 확인해야 하는 상황이 될 수 있다. 이처럼 관광산업특수분류를 활용하여 조 사 모집단을 정의하고 조사를 위한 모집단 명부 등을 작성하는데 혼란과 어려움이 발생한다면 관광산업특수분류의 활용도는 감소할 수밖에 없을 것이다.

이상에 살펴본 바와 같이 관광산업특수분류를 작성하고 활용하는데 어려움이 존 재하는 것이 현실이다. 하지만 앞으로 지속적인 연구 등을 통해서 관광산업특수분 류의 세부 분류 체계 등을 보다 명확하게 정리할 필요가 있다. 이러한 과정에서 각 산업들과 관광과의 관련 정도를 판단할 수 있는 보다 명확하고 객관적인 분류 기준 자료 생산이 우선적으로 검토되어야 할 것이다. 


\section{나. 관광산업특수분류 기준 자료로서 정교한 관광비(Tourism Ratio) 도출}

앞서 언급한 것과 같이 좀 더 정확한 관광산업특수분류를 위해서는 각 산업들과 관광과의 관련 정도를 파악할 수 있는 객관적인 자료가 필요하다. 즉 각 산업들의 생산활동 결과(예: 매출액) 중 관광과 관련된 비중을 의미하는 관광비(Tourism Ratio)를 추정할 필요가 있다.

한국표준산업분류 등에서 산업은 '유사한 성질을 갖는 산업활동에 주로 종사하는 생산단위의 집합' 으로, 산업활동은 '각 생산단위가 노동, 자본, 원료 등 자원을 투입 하여, 재화 또는 서비스를 생산 또는 제공하는 일련의 활동과정' 으로 정의된다. 그 리고 산업분류는 '생산단위(사업체단위, 기업체단위 등)가 주로 수행하는 산업활동 을 분류 기준과 원칙에 맞춰 그 유사성에 따라 체계적으로 유형화 한 것' 으로 정의 된다. 즉 산업분류는 '경제적 특성이 동일하거나 유사성을 갖는 산업활동의 집합 (group)'이다. 한국표준산업분류는 이러한 정의와 원칙에 따라 우리나라 산업을 분 류한 자료이다.

하지만 관광산업 분류에 있어서는 경제적 특성이 동일하거나 유사성을 갖는 산업 활동의 집합이라는 기준에 앞서 산업활동의 결과물(제품, 서비스 등)을 소비하는 주 체가 누구인지를 우선적으로 고려해야 한다.

기본적으로 관광산업 여부를 판단하는 1 차적 기준은 산업활동 결과물의 이용 대 상이 관광객인지 아닌지라 할 수 있다. 동일한 장소에서 동일한 서비스를 이용할 경우라도 관광객이 이용한다면 관광서비스로 볼 수 있지만 지역 주민 등 비관광객 이 이용한다면 관광서비스로 볼 수 없는 특성이 있는 것이다.

서울시의 한 식당에서 관광객이 식사를 한다면 관광서비스가 되지만 식당 주변 직장인이 식사를 한다면 관광서비스라 할 수 없다. 즉 어떠한 산업의 산업활동 결과 물을 이용하는 사람이 관광객이라면 관광산업의 성격을 갖게 되는 것이다. 최근 관 광활동이 양적으로 증가하고 그 범위가 확대되면서 전 산업영역이 관광활동과 관련 성을 갖고 있다고 해도 과언이 아닌 상황이다. 다만 전체 산업활동 결과 중 관광객 이 이용하는 비중 즉 관광비(Tourism Ratio)에는 차이가 존재하게 되는데 그 비중 이 높은 산업일수록 핵심적인 관광산업이라 할 수 있을 것이다.

만약 한국표준산업분류의 모든 산업을 대상으로 관광비를 도출할 수 있다면 이를 
근거로 핵심 관광산업, 상호의존 관광산업, 부분적용 관광산업 등을 보다 객관적으 로 분류할 수 있을 것이다. 예를 들어 관광비가 $50 \%$ 이상인 산업은 핵심 관광산업, $30 \%$ 이상 $50 \%$ 미만인 산업은 상호의존 관광산업, $10 \%$ 이상 $30 \%$ 이하인 산업 은 부분적용 관광산업으로 분류하는 방식이다.

하지만 현재 각 산업들의 관광비에 대한 추정은 체계적으로 이루어지고 있지 못 하다. 따라서 앞으로는 각 산업들의 관광비를 추정하는 방법에 대한 연구를 진행할 필요가 있다. 한국표준산업분류의 전 산업을 대상으로 관광비를 추정할 수 있다면 가장 이상적이겠으나 이는 상당히 어려운 작업이 될 것이다.

본 연구에서는 일반적으로 주요 관광산업으로 인식되고 있는 숙박업을 대상으로 관광비(Tourism Ratio) 추정을 위한 시범조사를 실시하였으나 업종별, 규모별로 관광비 추정의 접근방식이 달라질 수 있기 때문에 향후 시범조사를 수정 및 보완하 여 단계적으로 확장해 나가는 방식이 현실적인 접근이라 판단된다.

\section{다. 관광비 도출 방안}

각 산업들의 관광비를 도출하는 방법으로 우선 각 산업들을 대상으로 직접 관광 비를 조사하는 방법을 생각할 수 있다. 이러한 방식은 각 산업의 관광비 도출에 초 점을 두고 조사가 설계되고 진행되기 때문에 충실한 결과를 도출할 수 있을 것으로 기대된다. 하지만 관광비 도출을 위한 별도조사에 많은 예산과 시간 등이 투입되어 야 한다. 만약 관광비를 매년 도출해야 한다면 조사 역시 매년 실시되어야 할 것이 다. 이처럼 관광비 도출을 위하여 전 산업을 대상으로 직접 조사를 실시하는 것은 현실적으로 어렵고 비효율적일 것으로 판단된다.

현실성 및 효율성 차원에서 접근하면 전체 산업 또는 각 산업을 대상으로 정기적 으로 실시하고 있는 기존 통계조사와 연계하여 관광비를 도출하는 방법을 검토해 볼 수 있다. 시범조사 또는 새로운 통계 생산을 위하여 기존 통계조사에 일부 문항 을 추가하거나 조정하는 방식의 접근 사례들이 존재한다. 서비스업조사의 경우 숙 박업 등의 공유경제 활동 파악을 위해 시험 조사 성격으로 관련 문항을 추가하여 조사를 실시한 사례가 있다. 운수업조사의 경우 물류산업통계 개발을 목적으로 조 사 대상 사업의 종류를 추가 또는 세분하거나 일부 업종의 매출액 구성비를 추가하 
여 조사를 한 사례도 있다. 따라서 기존 산업통계 조사에 관광비를 파악할 수 있는 문항을 추가하는 방식의 개선을 검토해 볼 수 있을 것이다.

〈표 5-7〉 통계 생산 등을 위한 기존 통계조사 조정 사례

\begin{tabular}{|c|c|c|}
\hline 조사 명칭 & 조사 항목 조정 내역 & 조사 항목 조정 목적 \\
\hline 서비스업 조사 & 공유경제 활동 여부 파악 문항 추가(숙박업 등) & 시험 조사 \\
\hline 운수업 조사 & $\begin{array}{l}\text { 사업 종류 추가 } \\
\text { - } 49219 \text { 기타 도시 정기 육상 여객 운송업 } \\
\text { - } 49239 \text { 기타 부정기 여객 육상 운송업 } \\
\text { - } 52995 \text { 물류장비 임대업 } \\
\text { - } 52996 \text { 물류정보처리 서비스업 } \\
\text { - } 52997 \text { 물류컨설팅 관련 서비스업 } \\
\text { 사업 종류 세분 } \\
\text { - } 52931 \text { 공항 운영업 } \\
\text { - } 52939 \text { 기타 항공 운송지원 서비스업 } \\
\text { 물류산업 신성장 업종별 매출액 구성비 추가 } \\
\text { - 물류장비 임대업 매출액 구성비 } \\
\text { - 물류정보처리 서비스업 매출액 구성비 } \\
\text { - 물류컨설팅관련 서비스업 매출액 구성비 }\end{array}$ & 물류산업통계 개발 \\
\hline
\end{tabular}

우선은 전국 사업체를 대상으로 매년 실시되고 있는 '전국사업체조사'와 연계하 는 방안을 검토해 볼 수 있다. 전국사업체조사는 전국의 지역별 사업체의 규모 및 분포를 파악하여 정부의 정책 수립 및 평가, 기업의 경영 계획 수립 및 학술 연구 등의 기초자료로 활용하고 다른 통계조사의 모집단 명부로 활용하기 위한 목적으로 매년 실시되는 조사이다. 이 조사에서는 사업의 종류별 매출액 비중을 조사하고 있 는데 이를 활용하여 관광비를 도출하는 방안을 검토해 볼 수 있다. 한편 전국사업체 조사에서는 전체 응답 사업체들에게 프랜차이즈관련 사업체 여부를 조사하고 하고 있다. 또한 식·음료품 제조업(산업분류가 10,11 인 사업체)만을 대상으로는 원재료 로 쌀 소비여부를 파악하는 문항을 조사하고 있다. 이러한 사례를 고려해 보면 각 응답 사업체들의 관광비를 확인할 수 있는 문항25)을 추가하는 방식도 검토 가능할 것으로 판단된다.

25) 예를 들어 '연간 매출액 중 관광관련 매출액 비중'을 파악하는 방식이다. 
〈표 5-8〉 전국사업체조사 개요 및 관광비 조사 방안

\begin{tabular}{|c|c|}
\hline 구분 & 세부 내용 \\
\hline 작성 기관 & 통계청 \\
\hline 작성 유형 & 조사통계 \\
\hline 조사 대상 범위 & $\begin{array}{l}\text { - 모든 사업체를 대상으로 하되 다음 사업체는 제외 } \\
\text { - 개인이 경영하는 농림·어업사업체(법인 및 비법인 단체가 경영하는 사업체는 } \\
\text { 조사대상) } \\
\text { - 국방 및 가사서비스업 } \\
\text { - 국제기구 및 외국기관 } \\
\text { - 고정설비가 없거나 영업장소가 일정치 않은 간이 판매상 }\end{array}$ \\
\hline 조사 대상 지역 & 전국 \\
\hline 조사 단위 & 사업체 \\
\hline 조사 주기 & 1년 \\
\hline 관광비 도출 방안 & $\begin{array}{l}\text { - 기존 문항 활용 방안: 조사중인 사업의 종류 } \\
\text { - 주사업, 부사업 } 1, \text { 부사업 } 2 \text {, 부사업 } 3 \text { 별 매출액 비중 문항을 활용하는 방안 } \\
\text { - 신규 문항 추가 방안: 연간 매출액 중 관광관련 매출액 비중 조사 문항 추가 } \\
\text { - 프랜차이즈관련 사업체 여부 문항 조사 중 } \\
\text { - 산업분류가 } 10,11(\text { 식.음료품 제조업)인 사업체인 경우 원재료로 쌀 소비여부 } \\
\text { 문항 추가 조사 중 }\end{array}$ \\
\hline
\end{tabular}

전국사업체조사는 모든 사업체를 대상으로 조사가 이루어지기 때문에 관광비를 파악할 수 있는 문항이 추가된다면 가장 좋은 방안이 될 것이다. 만약 전국사업체조 사와 같이 전 사업체를 대상으로 하는 조사와 연계한 관광비 파악이 불가능하다면 일반적으로 관광과 관련 정도가 높다고 볼 수 있는 산업을 대상으로 실시되고 있는 조사와 연계하여 관광비를 조사하는 방안을 검토해 볼 수 있다. 우선 여러 관광산업 영역을 포함하고 있는 서비스업조사와 연계하는 방안이다. 서비스업조사는 서비스 업 부문에 대한 산업구조와 경영 실태 등을 종합적으로 파악하여 각종 정책 수립 및 관련 분야의 연구 분석을 위한 기초자료 제공을 목적으로 매년 실시되는 조사이 다. 서비스업조사 대상 중 도매 및 소매업, 숙박 및 음식점업, 예술/스포츠 및 여가 관련 서비스업 등은 관광과 관련이 높은 산업이다. 모든 조사 대상에게 공통적으로 적용해 볼 수 있는 관광비 조사 방법은 현재 조사중인 사업의 종류(주사업, 부사업 1 , 부사업 2, 부사업 3)별 매출액 비중 문항을 활용하는 방안이다. 다음으로 도매 및 소매업, 숙박업, 전문·과학-기술 서비스업(사진촬영 및 처리업)의 경우 현재 매 
출액 비중을 세분하는 문항이 조사되고 있는데 이와 같이 관광비를 파악할 수 있는 문항을 추가하는 방안을 검토해 볼 수 있다. 마지막으로 음식점 및 주점업, 부동산, 사업지원·임대, 교육서비스, 예술·스포츠·여가, 수리·개인서비스업 등은 관광비 문 항을 추가하는 방안을 검토해 볼 수 있다.

〈표 5-9〉서비스업조사 개요 및 관광비 조사 방안

\begin{tabular}{|c|c|}
\hline 구분 & 세부 내용 \\
\hline 작성 기관 & 통계청 \\
\hline 작성 유형 & 조사통계 \\
\hline 조사 대상 범위 & $\begin{array}{l}\text { E. 수도, 하수 및 폐기물 처리, 원료 재생업 } \\
\text { G. 도매 및 소매업(47920 노점 및 유사 이동 소매업, } 47999 \text { 그외 기타 무점포 } \\
\text { 소매업 제외) } \\
\text { I. 숙박 및 음식업점(56142 이동 음식업 제외) } \\
\text { J. 정보통신업(61 우편 및 통신업 제외) } \\
\text { L. 부동산업 } \\
\text { M. 전문, 과학 및 기술서비스업(70 연구개발업 제외) } \\
\text { N. 사업시설관리 및 사업지원 및 임대 서비스업 } \\
\text { P. 교육서비스업(851 } 854 \text { 제외, 855 } 857 \text { 일반 교습학원 및 기타교육기관 등만 조사) } \\
\text { Q. 보건업 및 사회복지 서비스업 } \\
\text { R. 예술, 스포츠 및 여가관련 서비스업 } \\
\text { S. 협회 및 단체, 수리 및 기타 개인서비스업(94 협회 및 단체 제외) }\end{array}$ \\
\hline 조사 대상 지역 & 전국 \\
\hline 조사 단위 & 약 200천개 사업체 \\
\hline 조사 주기 & 1년 \\
\hline 관광비 도출 방안 & $\begin{array}{l}\text { - 공통 적용 가능 방식: 조사중인 사업의 종류(주사업, 부사업 } 1 \text {, 부사업 2, 부사업 } \\
\text { 3)별 매출액 비중 문항을 활용하는 방안 } \\
\text { - 도매 및 소매업: 조사중인 상품 판매처별 매출액 구성비(본지점간 이동, 도매업자 } \\
\text { 등), 상품판매 유형별 매출액 구성비(매장판매, 방문판매 등) 문항과 같이 관광비 문 } \\
\text { 항을 추가하는 방안 } \\
\text { - 숙박업: 조사중인 유형별 매출액(객실료 수입액, 음식료 수입액 등) 문항과 같이 관 } \\
\text { 광비 문항을 추가하는 방안 } \\
\text { - 음식점 및 주점업 / 부동산 / 사업지원·임대 / 교육서비스 / 예술·스포츠·여가 / } \\
\text { 수리·개인서비스업: 관광비 문항을 추가하는 방안 } \\
\text { - 전문·과학·기술 서비스업(사진촬영 및 처리업): 조사중인 고객유ㅎㅕㅕ별 매출액 구성비 } \\
\text { (개인, 기업, 정부 등) 문항과 같이 관광비 문항을 추가하는 방안 }\end{array}$ \\
\hline
\end{tabular}


다음으로 관광과 관련 정도가 높은 식음료, 운수 등 각 산업별 조사와 연계하는 방안이다. 첫째, 외식업체경영실태조사와 연계하는 방안이다. 외식업체경영실태조 사는 외식업체의 세부적인 경영실태 조사 정보를 제공함으로써 외식업체의 경영 개 선을 위한 정책 사업을 개발하고 주기적인 정보 제공을 통해 외식업의 무분별한 진 입을 방지하고 경영 개선을 유도하기 위해 필요한 통계를 제공하기 위한 목적으로 매년 실시되고 있다. 현재 외식업체경영실태조사에서는 판매유형(음식점 내, 배달, 테이크아웃)별 매출액 비중을 조사하고 있다. 이와 유사하게 관광비를 파악할 수 있 는 문항을 추가하는 방안을 검토해 볼 수 있다.

〈표 5-10〉외식업체경영실태조사 개요 및 관광비 조사 방안

\begin{tabular}{|c|c|}
\hline 구분 & 세부 내용 \\
\hline 작성 기관 & 농림축산식품부 \\
\hline 작성 유형 & 조사통계 \\
\hline 조사 대상 범위 & 9차 한국표준산업분류 기준 숙박및 음식점업 중 음식점업(56)에 해당되는 모든 사업체 \\
\hline 조사 대상 지역 & 전국 \\
\hline 조사 단위 & $\begin{array}{l}\text { - 2016년 기준 전국사업체조사의 음식점업(56)에 속한 } 657,086 \text { 개 사업체를 모집단 } \\
\text { 으로 구분함(단독사업체와 본사, 지사(점) 등도 모집단에 포함함) } \\
\text { - 단독사업체: } 639,127 \text { 개소 } \\
\text { - 본사, 본점: } 1,056 \text { 개소 } \\
\text { - 공장, 지사, 영업소: } 16,903 \text { 개소 }\end{array}$ \\
\hline 조사 주기 & 1년 \\
\hline 관광비 도출 방안 & $\begin{array}{l}\text { - 조사중인 총 매출액 대비 판매유형별 매출액 비중(음식점 내, 배달, 테이크아웃) 문 } \\
\text { 항과 같이 관광비 문항을 추가하는 방안 }\end{array}$ \\
\hline
\end{tabular}

둘째, 운수업조사와 연계하는 방안이다. 운수업조사는 운수업 및 물류산업 부문 의 구조와 분포 및 경영실태 등을 종합적으로 파악하기 위하여 매년 실시되고 있다. 운수업조사는 일반 조사와 개인 조사(개인택시 등)로 구분된다. 일반조사의 경우 일 부 산업(물류장비 임대업, 물류정보처리 서비스업, 물류컨설팅 관련 서비스업)을 대 상으로 매출액의 세부 항목별 구성비를 조사하고 있다. 이와 같이 관광비를 파악할 수 있는 문항을 추가하는 방안을 검토해 볼 수 있다. 한편 개인 조사에는 매출액 구성비 관련 문항이 없으며, 관광비를 파악할 수 있는 문항을 추가하는 방안을 검토 해 볼 수 있다. 
〈표 5-11〉 운수업조사 개요 및 관광비 조사 방안

\begin{tabular}{|c|c|}
\hline 구분 & 세부 내용 \\
\hline 작성 기관 & 통계청 \\
\hline 작성 유형 & 조사통계 \\
\hline 조사 대상 범위 & 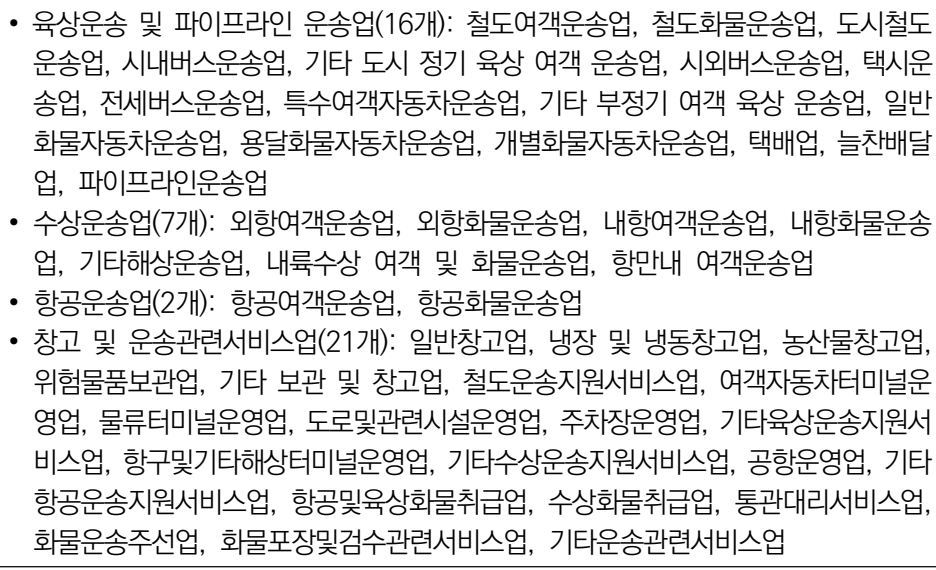 \\
\hline 조사 대상 지역 & 전국 \\
\hline 조사 단위 & 기업체(표본 수 약 10,000개 업체) \\
\hline 조사 주기 & 1년 \\
\hline 관광비 도출 방안 & $\begin{array}{l}\text { - 운수업 일반: 일부 산업(물류장비 임대업, 물류정보처리 서비스업, 물류컨설팅 관련 } \\
\text { 서비스업)의 매출액에 대해 세부 항목별 구성비를 조사하는 문항과 같이 관광비 문 } \\
\text { 항을 추가하는 방안 } \\
\text { - 운수업 개인(개인택시, 용달화물자동차, 개별화물자동차): 관광비 문항을 추가하는 } \\
\text { 방안 }\end{array}$ \\
\hline
\end{tabular}

셋째, 건설업조사와 연계하는 방안이다. 건설업조사는 우리나라 건설업부문의 구 조 및 산업활동 실태를 파악하여 정책 수립에 필요한 기초자료를 제공하기 위해 매 년 실시되고 있는 조사이다. 건설업조사에서는 공종별 총공사 금액, 당년도 기성액 등을 조사하고 있다. 공종세분류 중 관광과 관련 있는 부문은 토목 분야의 공항 (251), 건축 분야의 호텔·숙박시설(432), 전통양식건축(441), 기타문화재·유적건물 (442), 공연·집회장소(450), 전시시설(452), 마지막으로 조경공사 분야의 수목원 (610), 공원조성공사(611) 등이다. 따라서 전체 공사 금액 중 관광과 관련 있는 공 종의 공사비 비율 등을 관광비로 활용하는 방안을 검토해 볼 수 있다. 
〈표 5-12〉 건설업조사 개요 및 관광비 조사 방안

\begin{tabular}{c|l}
\hline 구분 & \multicolumn{1}{c}{ 세부 내용 } \\
\hline 작성 기관 & 통계청 \\
\hline 작성 유형 & 조사통계 \\
\hline 조사 대상 범위 & 기업체 \\
\hline 조사 대상 지역 & 전국 \\
\hline 조사 단위 & 기업체(약 7만 5천여개 기업체) \\
\hline 조사 주기 & 1년 \\
\hline 관광비 도출 방안 & 총 공사 금액 중 관광과 관련 있는 공종의 금액을 관광비로 활용하는 방안 \\
\hline
\end{tabular}

넷째, 농림어업조사와 연계하는 방안이다. 농림어업조사는 전국의 농림어가의 규 모, 인구, 분포 및 경영 형태를 파악하여 농림어업 농산촌 정책의 수립 및 평가를 위한 기초자료 제공을 목적으로 매년 실시되고 있는 조사이다. 농림어업조사는 농 가, 임가, 해수면 어업가, 내수면 어업가로 구분하여 조사가 이루어진다. 농가 조사 의 경우 현재 조사중인 지난 1 년간 농업관련 사업 문항의 농촌관광 사업(주말농원, 민박 등) 응답 비율을 활용하여 관광비를 추정하는 방안, 연간 매출액 중 관광관련 매출액 비중 조사 문항을 추가하는 방안 등을 검토해 볼 수 있다. 해수면 어가 조사 의 경우 현재 조사중인 지난 1 년간 어업관련 사업 문항의 어촌관광 사업(민박 등) 및 낚시안내업 응답 비율을 활용하여 관광비를 추정하는 방안, 연간 매출액 중 관광 관련 매출액 비중 조사 문항을 추가하는 방안 등을 검토해 볼 수 있다. 임가 및 내수 면 어가 조사의 경우 현재 관광관련 문항이 없기 때문에 연간 매출액 중 관광관련 매출액 비중 조사 문항을 추가하는 방안 등을 검토해 볼 수 있다. 
〈표 5-13〉 농림어업조사 개요 및 관광비 조사 방안

\begin{tabular}{|c|c|}
\hline 구분 & 세부 내용 \\
\hline 작성 기관 & 통계청 \\
\hline 작성 유형 & 조사통계 \\
\hline 조사 대상 범위 & 가구 \\
\hline 조사 대상 지역 & 전국 \\
\hline 조사 단위 & $\begin{array}{l}\text { - 2019년 조사: } 45,320 \text { 개 농림어가( } 45,320 \text { 개 농가, 4,486개 임가, 4,513개 해수면 } \\
\text { 어가, } 706 \text { 개 내수면 어가) } \\
\text { - 농가. 임가 중복: } 3,108 \text { 개 가구 }\end{array}$ \\
\hline 조사 주기 & 1년 \\
\hline 관광비 도출 방안 & $\begin{array}{l}\text { - 농가 } \\
\text { - 기존 문항 활용 방안: 조사중인 지난 } 1 \text { 년간 농업관련 사업 문항의 농촌관광 사업 } \\
\text { (주말농원, 민박 등) 응답 비율을 활용하는 방안 } \\
\text { - 신규 문항 추가 방안: 연간 매출액 중 관광관련 매출액 비중 조사 문항 추가 } \\
\text { - 임가: 연간 매출액 중 관광관련 매출액 비중 조사 문항 추가 } \\
\text { - 해수면 어가 } \\
\text { - 기존 문항 활용 방안: 조사중인 지난 } 1 \text { 년간 어업관련 사업 문항의 어촌관광 사업 } \\
\quad \text { (민박 등), 낚시안내업 응답 비율을 활용하는 방안 } \\
\text { - 신규 문항 추가 방안: 연간 매출액 중 관광관련 매출액 비중 조사 문항 추가 } \\
\text { - 내수면 어가: 연간 매출액 중 관광관련 매출액 비중 조사 문항 추가 }\end{array}$ \\
\hline
\end{tabular}

\section{라. 지역별 관광비 활용}

만약 각 산업과 관광과의 관련 정도를 파악할 수 있는 관광비가 추정된다면 지역 (예; 광역지자체)별로 각 산업별 관광비를 활용할 필요가 있다. 전국단위로 각 산업 별 관광비를 추정한다면 이는 산업별 평균 관광비의 개념이 될 것이다. 하지만 광역 지자체별로 지역경제에서 관광산업이 차지하는 비중이 상이하며 또한 특화된 세부 관광산업도 상이할 가능성이 높다. 따라서 각 지역별 관광비를 적용하여 관광산업 의 규모를 추계하고 지역 관광산업의 구조를 분석할 필요가 있다.

지역별·산업별 관광비를 활용할 경우 각 지역의 관광산업 구조, 특화 관광산업 등을 보다 명확하게 파악할 수 있을 것이다. 이러한 기초 자료는 지역의 관광산업 경쟁력을 키우기 위한 관광산업 정책 수립에 도움을 줄 수 있을 것이다. 타 지역에 비해 상대적으로 관광비가 높은 산업 또는 관광비가 낮은 산업 등을 명확하게 확인 할 수 있기 때문에 보다 효율적인 관광산업 정책 수립에도 기여할 것으로 기대된다. 


\section{2. 관광산업통계 생산 관련 제언}

\section{가. 관광산업특수분류를 활용한 관광산업 통계 생산 방안 지속 개선}

그동안 대표적인 관광산업 통계인 관광사업체조사 등은 관광진흥법에서 제시하 고 있는 관광사업체를 모집단으로 생산되었다. 이러한 방식은 모집단이 명확하다는 장점은 있으나 관광산업의 현실적인 범위를 제대로 반영하지 못하고 있다는 한계를 갖고 있다. 이러한 한계를 완화하기 위하여 본 연구에서는 관광산업특수분류를 개 정하였고 이를 활용하여 관광산업통계 생산방안을 검토하였다. 앞으로 종합적이고 체계적인 관광산업 육성정책 수립 및 추진을 위해서는 관광진흥법의 관광산업을 포 함한 미시적 차원의 통계 생산과 더불어 관광산업특수분류에 기반을 둔 거시적 차 원의 관광산업통계 생산방안 마련이 필요할 것이다.

본 연구에서는 실제 거시적 차원의 관광산업통계 생산 준비 차원에서 관광산업특 수분류를 활용한 통계생산방안을 검토하였다. 따라서 향후에는 실제 관광산업통계 조사가 관광산업특수분류에 기반하여 실시될 수 있도록 보다 심도 있는 연구와 시 범 조사 등이 이루어져야 할 것이다. 또한 앞서 언급한 것과 같이 개정된 관광산업 특수분류 보완 및 개선 등과 함께 관광산업통계 생산 방안도 보완 및 개선이 함께 이루어져야 할 것이다. 관광산업특수분류를 활용한 관광산업통계 생산의 실효성을 제고하기 위해서는 관광산업특수분류를 보완 및 개선과 동시에 관광산업통계 생산 가능성도 함께 검토해야 할 것이다.

\section{나. 다양한 관광산업통계 생산 방안 검토}

관광진흥법에서 규정하고 있는 관광산업의 범위와 관광산업특수분류에서 제시된 관광산업의 범위 사이에는 상당히 큰 차이가 존재한다. 본 연구에서 검토한 자료에 의하면 핵심관광산업에서 관광진흥법상 관광사업체를 포괄하는 'a' 코드 관광사업체 수는 49,353개소인 반면 관광산업특수분류 4 개 분류에 모두 포함된 관광사업체 수 는 722,853 개에 이른다. 따라서 관광산업통계 조사의 모집단을 관광진흥법상 관광 사업체에서 관광산업특수분류로 조정하기 위해서는 상당히 많은 예산 및 시간과 노 력 등이 필요할 것으로 예상되며, 모집단 확인 등 실무적인 차원에서도 많은 어려움 
이 발생할 것으로 예상된다. 따라서 관광산업 통계 조사의 기반을 관광진흥법상 관 광산업에서 관광산업특수분류로 한 번에 변경하는 것은 현실적으로 어려울 것으로 예상된다. 따라서 관광산업통계 조사의 기반이 관광진흥법상 관광산업에서 관광산 업특수분류로 자연스럽게 변경될 수 있는 다양한 방안을 검토할 필요가 있다.

첫째, 관광산업통계 조사의 대상을 관광산업특수분류로 하되 단계적으로 조사 대 상을 확대하는 방안이다. 즉 1 차적으로는 핵심 관광산업을 대상으로 관광산업 통계 조사를 실시한 후 통계생산 방법을 보완 및 개선하면서 상호의존 관광사업, 부분적 용 관광산업, 관광 지원사업 등으로 조사 범위를 단계적으로 확대하는 방안이다. 이 처럼 관광산업 통계 조사의 대상을 관광산업특수분류 전체로 단계적으로 확대한다 면 조사과정에서의 시행착오 등을 지속적으로 개선하면서 보다 완성도 있는 관광산 업통계 조사를 실시할 수 있을 것이다.

둘째, 관광산업통계 조사를 이원화 하는 방안이다. 관광산업특수분류로 관광산업 통계 조사의 대상을 확대한다 하여도 관광산업특수분류의 모든 범위가 관광산업 정 책대상이 되기는 어려울 것이다. 따라서 관광산업특수분류의 대분류 중 관광산업 정책의 대상이 되는 주요 영역에 대해서는 실태조사를 실시하고 기타 대분류 영역 에 대해서는 핵심 정보를 추계하는 방식을 검토해 볼 수 있다. 예를 들면 관광산업 정책의 주요 대상이 될 가능성이 높은 핵심 관광산업에 대해서는 대면 조사 등을 통해 다양한 내용에 대한 실태조사를 실시하는 방안이다. 핵심 관광산업 이외의 상 호의존 관광산업, 부분적용 관광산업, 관광 지원산업 등에 대해서는 사업체 수를 파 악하고, 관광비 등을 적용한 매출액 또는 종사자 수 추정 등 핵심적인 기초 정보를 생산하는 방안이다. 이처럼 관광산업통계를 이원화 한다면 관광산업 정책 수립에 필요한 기초적인 정보들을 보다 효율적으로 생산할 수 있을 것으로 기대된다.

\section{다. 관광산업특수분류를 활용한 관광위성계정 작성}

관광산업에 대한 명확한 분류 기준을 설정하기 어렵기 때문에 관광관련 산업통계 가 국민계정 내에 존재함에도 불구하고 관광산업통계를 분리 추출하는데 어려움이 존재한다. 관광지출 측면에서 관광객의 지출항목에서 관광산업의 규모를 추정할 수 있지만 분류의 한계로 인해 국민계정과 연계하는데 어려움이 존재하는 것이다. 이 
러한 한계를 보완하기 위하여 국민계정 내에 관광산업으로 분류되지 않은 관광산업 의 규모를 분석하기 위해 관광위성계정 작성이 시도되고 있다. 관광위성계정은 수 요 및 공급과 관련된 관광 관련 자료를 폭넓게 조정하는 개념적인 체계로 관광산업 의 규모를 추정하는데 활용된다. 따라서 국가 전체 경제측면에서 보다 관광산업의 규모와 그 위상을 파악하기 위해서 현재 관광위성계정 추정 연구가 다양하게 수행 되고 있다.

관광위성계정 작성을 위해서는 수요측면 및 공급측면에 대한 통계자료와 산업연 관표 등 다양한 기초통계가 필요하다. 관광산업특수분류에서 제시된 업종들은 관광 위성계정에서 제시된 소비자 관광상품을 대부분 포함하고 있는 상황이다. 관광산업 특수분류의 관광산업 대분류는 핵심 관광산업, 상호의존 관광산업, 부분적용 관광 산업, 관광 지원산업이다. 한편 관광위성계정 작성과 관련된 관광상품 분류는 주로 TSA:RMF 2008(Tourism Satellite Account: Recommended Methodological Framework 2008)을 적용하고 있다. TSA:RMF 2008에서 제시하고 있는 관광상 품 대분류는 핵심 관광상품, 관광관련 상품, 기타 상품 분류이며, 우리나라에서 작 성했던 한국 관광위성계정의 관광상품 대분류는 핵심 관광상품, 관광관련 상품, 기 타 관광상품이다. 따라서 관광산업특수분류를 활용하여 관광산업통계를 생산한다면 관광위성계정의 공급부문 작성을 위한 기초자료로 활용될 수 있을 것이다. 관광산 업특수분류가 좀 더 체계화 된다면 관광위성계정 작성과의 연계성도 제고될 수 있 을 것으로 기대된다.

\section{라. 관광산업특수분류를 활용한 관광산업통계 생산 협력 체계 구축}

관광산업의 범위가 점점 확장되고 타 산업과의 경계도 모호해지는 현상은 앞으로 도 지속될 것으로 전망된다. 따라서 관광산업특수분류에 포함되는 산업의 범위도 점점 확대될 가능성이 높다. 이는 관광산업이 문화체육관광부 뿐만 아니라 거의 대 부분의 정부 부처 업무 영역과 관련될 가능성이 높다는 의미이기도 하다. 앞으로 점점 확대되는 관광산업의 변화를 반영하여 관광산업특수분류를 보완 및 개정하고 이를 활용한 관광산업 통계를 생산하기 위한 범 부처차원의 협력체계 구축이 필요 할 것이다. 특히나 앞서 제시한 관광비(Tourism Ratio) 도출을 위한 기존 통계조 
사 활용가능성 검토 등에서는 관련 부처와의 업무 협력이 더욱 필요해 보인다. 나아 가 종합적이고 체계적인 관광산업 육성 정책 수립 및 추진을 위해서도 부처간 협력 체계 구축이 필요한 상황이다. 내부적으로도 보다 시의성 있고 활용성이 높은 통계 생산을 위한 협력체계 마련이 필요하다. 현재 관광사업체조사는 문화체육관광부 관 광산업정책과가 진행하고 있다. 최근에는 문체부 내에 정책분석팀이 신설되어 효율 적 업무진행을 위한 협업이 더욱 중요해졌다. 정책분석팀은 문화체육관광부와 그 소속기관·공공기관의 통계·공공데이터·빅데이터에 관한 기획, 예산 검토·조정·작 성, 활용 기반 구축 및 관리 총괄하는 업무를 수행한다. 향후 관광산업정책과 및 정 책분석팀과 긴밀한 협의를 통해 관광산업통계의 확대 및 부처별 협력체계 구축을 위한 다양한 노력이 필요할 것이다. 


\section{참고문헌}

- 문화체육관광부(2008), 『2007년 기준 관광사업체 기초통계조사」.

- 문화체육관광부(2009), 『2008년 기준 관광사업체 기초통계조사』.

- 문화체육관광부(2010), 『2009년 기준 관광사업체 기초통계조사』.

- 문화체육관광부(2011), 『2010년 기준 관광사업체 기초통계조사』.

- 문화체육관광부(2012), 『2011년 기준 관광사업체 기초통계조사』.

- 문화체육관광부(2012), 『관광산업특수분류』.

- 문화체육관광부(2013), 『2012년 기준 관광사업체 기초통계조사」.

- 문화체육관광부(2014), 『2013년 관광사업체 기초통계조사』.

- 문화체육관광부(2015), 『2014년 관광사업체 기초통계조사』.

- 문화체육관광부(2016), 『2015년 관광사업체 기초통계조사』.

- 문화체육관광부(2017), 『2016년 관광사업체 기초통계조사』.

- 문화체육관광부(2018), 『2017년 관광사업체 기초통계조사』.

- 문화체육관광부(2018), 『관광사업 분류체계 연구』.

- 문화체육관광부(2019), 『2018 관광사업체조사」.

- 문화체육관광부(2020), 『2019 콘텐츠산업 통계조사』.

- 문화체육관광부, 『2016년도 문화체육관광분야 사업체 표본틀 구축』.

- 문화체육관광부, 『2017년도 문화체육관광분야 사업체 표본틀 구축』.

- 산업연구원(2016), 『관광산업 통계기반 개선사업 연구』.

- 이종성(2001), 델파이 방법. 교육과학사.

- 진영(1998), 네이만배분법과 수정절사법의 효율성 비교. 통계청「통계분석연구」, 제3권 2호, 77-99.

- 통계청(2008), 『한국표준산업분류』.

- 통계청(2012), 『관광사업체기초통계조사 품질개선 컨설팅 최종결과보고서: 관광산 업 특수분류체계 개선」.

- 통계청(2017), 『한국표준산업분류』. 
- 통계청(2015), 『2014년 기준 전국사업체조사 보고서』.

- 통계청(2016), 『2015년 기준 전국사업체조사 보고서』.

- 통계청(2017), 『2016년 기준 전국사업체조사 보고서』.

- 통계청(2018), 『2017년 기준 전국사업체조사 보고서』.

- 한국관광공사(2017), 『MICE산업분류 구축방안 연구』.

- 한국관광협회중앙회(2018), 『문화체육관광 위성계정 구축방안 연구』.

- 한국문화정보원(2015), 『문화체육관광 국가승인통계 표본설계 및 추정 방안 연구․

- 한국저작권위원회(2013), 『한국의 저작권산업 경제 기여도 조사』.

- 한국저작권위원회(2018), 『한국의 저작권산업 경제 기여도 조사』.

- 한국콘텐츠진흥원(2010), 『중국 문화산업진출 Guidebook』.

- BrocNhoff, K. (1975), The performance of forecasting groups in computer dialog and face-to-face discussion. The Delphi method: Techniques and applications, 291-321.

- Dalkey, N. C. (1969), The Delphi method: An experimental study of group opinion (No. RM-5888-PR). RAND CORP SANTA MONICA CALIF.

- Delbecq, A. L., Van de Ven, A. H., \& Gustafson, D. H. (1975), Group techniques for program planning: A guide to nominal group and Delphi processes. Scott, Foresman.

- Hidiroglou, M. A. (1986), The construction of a self-representing stratum of large units in survey design. The American Statistician, 40(1), 27-31.

- Hansen, M. H., Hurwiz, W. N. and Madow, W. G.(1953), Sample Survey Methods \& Theory Vol.2, New York: John Wiley.

- Lawshe, C. H. (1975), A quantitative approach to content validity. Personnel psychology, 28(4), 563-575.

- Lohr, S. L. (2009), Sampling: design and analysis. Nelson Education.

- Rowe, G., \& Wright, G. (2001), Expert opinions in forecasting: the role of the Delphi technique. In Principles of forecasting (pp. 125-144). Springer, Boston, MA.

- UNWTO(1994), 『Recommendations on Tourism Statistics」.

- UNWTO(2008), Global Meeting Initiative Vol 1.

- UNWTO(2018), ${ }^{『}$ Methodological Notes to the Tourism Statistics Database 
- United Nations (2008), Tourism Satellite Account: Recommended Methodological Framework 2008.

- United Nations(2010), International Recommendations for Tourism Statistics 2008(IRTS 2008).

- United Nations and World Tourism Organization(1994), Recommendations on Tourism Statistics.

- World Intellectual Property Organization(2003), Guide on Surveying the Economic, Contribution of the Copyright-Based Industries. 



\section{ABSTRACT}

\section{Production Plan Study of Tourism Industry Statistics Based on the Revised Special Classification of Tourism Industry}

This study was promoted to underestimate the problem of underestimating the tourism industry, the limitations of the existing tourism industry special classification system, to prepare an internationally comparable industry classification, and to accurately estimate the size of the tourism industry. Therefore, the purposes of this study are as follows. First, the third amendment to the special classification of the tourism industry is drawn. Through this, a comprehensive concept of tourism industry is defined in the existing micro-level tourism industry, and a plan to separately deduce the industry subject to policy support by the Ministry of Culture, Sports and Tourism is proposed. Second, a survey group is derived for each stage applying the "tourism industry special classification". A sample frame for the survey is presented based on the National Statistical Office's national business survey population. Review the contents of "item analysis" to accurately derive the tourism industry and grasp the structure of the raw data of the national business survey. Through this, we derive a population by stage that can be surveyed by applying the special classification of the tourism industry. Third, a survey plan for tourism industry statistics applying 'special classification for tourism industry' is prepared. The scope of tourism industry research is expanded by reorganizing the consultation of tourism company research, which was investigated through the definition of the existing Tourism Promotion Act, into a broader research method applying a special classification system for the tourism industry. The implications through

this study are as follows. First, it is necessary to continue to improve the special classification of the tourism industry that can reflect the actual tourism 
industry. Changes in the tourism industry are expected to continue in the future, with the scope of the tourism industry expanding and the blurring of the boundaries with other industries. Considering these changes, it is considered to be more desirable to set the scope of the tourism industry at a macro level focusing on the special classification of the tourism industry rather than the microscopic tourism industry stipulated in the Tourism Promotion Act. To this end, continuous supplementation and improvement of the special classification of the tourism industry must be supported. Second, it is necessary to derive elaborate tourism ratio as the standard data for special classification of the tourism industry. For accurate tourism industry special classification, objective data that can grasp the degree of relationship between each industry and tourism are needed. In other words, it is necessary to estimate the tourism ratio, which means the proportion related to tourism among the results of each industry's production activities (eg, sales). Third, it is necessary to prepare a method for producing statistics for the tourism industry using the special classification of the tourism industry. In order to establish and promote a comprehensive and systematic tourism industry promotion policy, it is necessary to prepare a macro level tourism industry statistics production plan based on the tourism industry special classification as well as micro-level statistics production including the tourism industry under the Tourism Promotion Act. Fourth, it is necessary to establish a cooperation system for the production of statistics in the tourism industry. The phenomenon that the scope of the tourism industry is gradually expanding and the boundaries with other industries are blurred is expected to continue in the future. Therefore, there is a high possibility that the range of industries included in the special classification of the tourism industry will gradually expand. This also means that the tourism industry is highly likely to be related not only to the Ministry of Culture, Sports, and Tourism, but also to the work area of most government departments. It is necessary to establish a cooperative system at the ministry level, in order to supplement and revise the tourism industry special classification to reflect the expanding tourism industry in the future, and to produce tourism industry statistics using this.

\section{Keywords}

Tourism Industry Special Classification, Tourism Industry Statistics 
관광산업특수분류 개정안에 기초한 관광산업통계 생산방안 연구

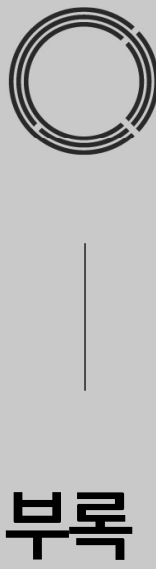





\section{【부록】전문가 의견 조사지 \& 관광요소비중 조사 설문지}

\section{관광산업통계 생산을 위한 관광산업특수분류 개정안 도출 설문지}

안녕하십니까?

본 조사는 '관광산업특수분류 개정안에 기초한 관광산업통계 생산방안 연구'를 통해 정확한 관광산업통 계 생산을 위한 관광산업특수분류 개정안을 제시하고자 실시하고 있습니다, 응답해 주신 사항은 익명으로 처리되며, 연구 이외의 목적에는 이용되지 않습니다. 바쁘신 와중에 설문에 참여해 주셔서 진심으로 감사드립니다.

연구자: 권태일 연구위원(02-2669-8902, tikwon@kcti.re.kr)

\begin{tabular}{|c|c|c|}
\hline 구분 & (1) 학계 $\quad$ (2) 관련 기관 $\quad$ (3) 정부기관 \\
\hline 연락처 & & \\
\hline E-mail & & \\
\hline
\end{tabular}

\section{관광산업특수분류}

관광산업특수분류는 세계관광기구(UNWTO)와 유엔통계위원회가 공동으로 작성한 관광활동의 국제표준 분류(SICTA)를 기초로 국내 산업의 특성을 반영하여 2000년에 제정되었습니다.

관광산업특수분류에서 관광산업은 크게 핵심관광산업을 중심으로 관광산업에 대한 기여도와 역할에 따라 상호의존 관광산업, 부분적용 관광산업, 관광지원산업으로 구분하고 있습니다.

\begin{tabular}{|c|c|}
\hline 구분 & 정의 \\
\hline 핵심관광산업 & $\begin{array}{l}\text { 전적으로 관광객에 의존하는 산업으로 관광 쇼핑업, 관광 운수업, 관광 숙박업, 관광 음 } \\
\text { 식점 및 주점업, 여행사 및 여행보조 서비스업, 국제회의업, 문화·오락 및 레저 스포츠산 } \\
\text { 업, 카지노업을 포함하며, 주로 관광진흥법에서 규정한 관광산업을 포함함 }\end{array}$ \\
\hline $\begin{array}{l}\text { 상호의존 } \\
\text { 관광산업 }\end{array}$ & $\begin{array}{l}\text { 원래 관광산업은 아니지만 핵심 관광산업을 보 } \\
\text { 건설업, 관광 및 레저용품 소매업, 관광 금융 }\end{array}$ \\
\hline $\begin{array}{l}\text { 부분적용 } \\
\text { 관광산업 }\end{array}$ & $\begin{array}{l}\text { 부분적으로 관광객에 의존하는 산업으로 관광 비인증 쇼핑업, 부분관광 운송업, 부분관 } \\
\text { 광 숙박업, 부분관광 음식점 및 주점업, 부분관광 공연장업, 부분관광 기타 서비스업을 } \\
\text { 포함함 }\end{array}$ \\
\hline 간광 ᄌ & $\begin{array}{l}\text { 관광산업을 지원하기 위한 부문으로 관광관련 관광 연구 개발업, 관광 공공기관, 관광 } \\
\text { 교육서비스업, 관광단체를 포함함 }\end{array}$ \\
\hline
\end{tabular}

본 조사에서는 핵심관광산업에 해당하는 산업을 파악하고자 2012년에 마지막으로 개정된 관광산업특수분 류를 기준으로 핵심관광산업, 상호의존 관광산업, 부분적용 관광산업에 포함되는 각각의 산업이 산업 환경 변화 등에 따라 현재에는 관광핵심산업에 어느 정도 포함되는지를 살펴보고자 합니다. 


\section{I. 관광산업특수분류 관광핵심산업}

관광산업특수분류의 관광핵심산업입니다. 관광핵심산업에 해당하는 정도를 체크 $(\boldsymbol{v})$ 해 주시기 바랍니다. 분류에서 $\mathrm{a}$ 는 관광진흥법상의 관광사업을 의미합니다.

\begin{tabular}{|c|c|c|c|c|c|c|c|c|c|}
\hline \multicolumn{3}{|c|}{ 구분 } & \multicolumn{3}{|c|}{ 관광핵심산업은 아니다 — } & \multirow{2}{*}{$\begin{array}{l}\text { 보통 } \\
\text { (4) }\end{array}$} & \multicolumn{3}{|c|}{$\rightarrow$ 관광핵심산업이다 } \\
\hline \multirow{3}{*}{$\begin{array}{l}\text { 관광 쇼핑업 } \\
\text { (도매업 제외) }\end{array}$} & \multicolumn{2}{|l|}{ 면세점 } & (1) & (2) & (3) & & (5) & (6) & (7) \\
\hline & \multicolumn{2}{|c|}{ 외국인전용 관광기념품 판매업 } & (1) & (2) & (3) & (4) & (5) & (6) & (7) \\
\hline & \multicolumn{2}{|c|}{ 관광 인증 쇼핑업 } & (1) & (2) & (3) & (4) & (5) & (6) & (7) \\
\hline \multirow{8}{*}{$\begin{array}{l}\text { 관광 } \\
\text { 운수업 }\end{array}$} & \multicolumn{2}{|c|}{ 관광 철도운송업 } & (1) & (2) & (3) & (4) & (5) & (6) & (7) \\
\hline & \multirow{3}{*}{$\begin{array}{c}\text { 관광 } \\
\text { 도로운송업 }\end{array}$} & 시내순환 관광업a & (1) & (2) & (3) & (4) & (5) & (6) & (7) \\
\hline & & 전세버스 운송업 & (1) & (2) & (3) & (4) & (5) & (6) & (7) \\
\hline & & 관광궤도업a & (1) & (2) & (3) & (4) & (5) & (6) & (7) \\
\hline & \multirow{2}{*}{$\begin{array}{c}\text { 관광 } \\
\text { 수상운송업 }\end{array}$} & 관광 유람선업a & (1) & (2) & (3) & (4) & (5) & (6) & (7) \\
\hline & & 크루즈업a & (1) & (2) & (3) & (4) & (5) & (6) & (7) \\
\hline & \multirow{2}{*}{$\begin{array}{c}\text { 관광 } \\
\text { 항공운송업 }\end{array}$} & 관광 항공 정기운송업 & (1) & (2) & (3) & (4) & (5) & (6) & (7) \\
\hline & & 관광 항공 부정기운송업 & (1) & (2) & (3) & (4) & (5) & (6) & (7) \\
\hline \multirow{16}{*}{$\begin{array}{l}\text { 관광 } \\
\text { 숙박업 }\end{array}$} & \multirow{5}{*}{ 호텔업 } & 관광 호텔업a & (1) & (2) & (3) & (4) & (5) & (6) & (7) \\
\hline & & 수상관광 호텔업a & (1) & (2) & (3) & (4) & (5) & (6) & (7) \\
\hline & & 한국전통 호텔업a & (1) & (2) & (3) & (4) & (5) & (6) & (7) \\
\hline & & 가족 호텔업a & (1) & (2) & (3) & (4) & (5) & (6) & (7) \\
\hline & & 호스텔업a & (1) & (2) & (3) & (4) & (5) & (6) & (7) \\
\hline & \multicolumn{2}{|c|}{ 휴양콘도미니엄업a } & (1) & (2) & (3) & (4) & (5) & (6) & (7) \\
\hline & \multicolumn{2}{|c|}{ 관광 펜션업a } & (1) & (2) & (3) & (4) & (5) & (6) & (7) \\
\hline & \multirow{9}{*}{$\begin{array}{l}\text { 일반 관광 } \\
\text { 숙박업 }\end{array}$} & 산림휴양림업 & (1) & (2) & (3) & (4) & (5) & (6) & (7) \\
\hline & & 게스트하우스 & (1) & (2) & (3) & (4) & (5) & (6) & (7) \\
\hline & & 레지던스 호텔 & (1) & (2) & (3) & (4) & (5) & (6) & (7) \\
\hline & & 관광 인증 모텔업 & (1) & (2) & (3) & (4) & (5) & (6) & (7) \\
\hline & & 민박업 & (1) & (2) & (3) & (4) & (5) & (6) & (7) \\
\hline & & 외국인 관광 도시민박업a & (1) & (2) & (3) & (4) & (5) & (6) & (7) \\
\hline & & 자동차 야영장업a & (1) & (2) & (3) & (4) & (5) & (6) & (7) \\
\hline & & 한옥체험업a & (1) & (2) & (3) & (4) & (5) & (6) & (7) \\
\hline & & 기타 관광 숙박시설 운영업 & (1) & (2) & (3) & (4) & (5) & (6) & (7) \\
\hline \multirow{5}{*}{$\begin{array}{c}\text { 관광 음식점 } \\
\text { 및 주점업 }\end{array}$} & \multicolumn{2}{|c|}{ 관광 식당업a } & (1) & (2) & (3) & (4) & (5) & (6) & (7) \\
\hline & \multirow{4}{*}{$\begin{array}{l}\text { 관광 } \\
\text { 주점업 }\end{array}$} & 관광 유흥음식점업a & (1) & (2) & (3) & (4) & (5) & (6) & (7) \\
\hline & & 관광 극장유흥업a & (1) & (2) & (3) & (4) & (5) & (6) & (7) \\
\hline & & 관광 공연장업a & (1) & (2) & (3) & (4) & (5) & (6) & (7) \\
\hline & & 외국인전용 유흥음식점업a & (1) & (2) & (3) & (4) & (5) & (6) & (7) \\
\hline
\end{tabular}




\begin{tabular}{|c|c|c|c|c|c|c|c|c|c|}
\hline \multicolumn{3}{|c|}{ 구분 } & \multicolumn{3}{|c|}{ 관광핵심산업은 아니다 - } & \multirow{2}{*}{$\begin{array}{l}\text { 보통 } \\
\text { (4) }\end{array}$} & \multicolumn{3}{|c|}{$\rightarrow$ 관광핵심산업이다 } \\
\hline \multirow{4}{*}{$\begin{array}{l}\text { 여행사 및 여행 } \\
\text { 보조 서비스업 }\end{array}$} & \multirow{3}{*}{ 여행업 } & 일반 여행업a & (1) & (2) & (3) & & (5) & (6) & (7) \\
\hline & & 국외 여행업a & (1) & (2) & (3) & (4) & (5) & (6) & (7) \\
\hline & & 국내 여행업a & (1) & (2) & (3) & (4) & (5) & (6) & (7) \\
\hline & \multicolumn{2}{|c|}{ 여행보조 및 예약 서비스업 } & (1) & (2) & (3) & (4) & (5) & (6) & (7) \\
\hline \multirow{2}{*}{ 국제회의업 } & \multicolumn{2}{|c|}{ 국제회의 기획업a } & (1) & (2) & (3) & (4) & (5) & (6) & (7) \\
\hline & \multicolumn{2}{|c|}{ 국제회의 시설업 } & (1) & (2) & (3) & (4) & (5) & (6) & (7) \\
\hline \multirow{16}{*}{$\begin{array}{l}\text { 문화, 오락 및 } \\
\text { 레저 스포츠산업 }\end{array}$} & \multirow{2}{*}{$\begin{array}{c}\text { 박물관 및 } \\
\text { 사적지 } \\
\text { 관리 운영업 }\end{array}$} & 박물관 운영업(미술관 포함) & (1) & (2) & (3) & (4) & (5) & (6) & (7) \\
\hline & & 사적지 관리 운영업 & (1) & (2) & (3) & (4) & (5) & (6) & (7) \\
\hline & \multirow{3}{*}{$\begin{array}{l}\text { 식물원, } \\
\text { 동물원 및 } \\
\text { 자연공원 } \\
\text { 운영업 }\end{array}$} & 식물원, 동물원 운영업 & (1) & (2) & (3) & (4) & (5) & (6) & (7) \\
\hline & & 자연공원 운영업 & (1) & (2) & (3) & (4) & (5) & (6) & (7) \\
\hline & & 기타 관광지 운영업 & (1) & (2) & (3) & (4) & (5) & (6) & (7) \\
\hline & \multirow{3}{*}{ 유원시설업 } & 종합유원시설업a & (1) & (2) & (3) & (4) & (5) & (6) & (7) \\
\hline & & 일반유원시설업a & (1) & (2) & (3) & (4) & (5) & (6) & (7) \\
\hline & & 기타유원시설업 & (1) & (2) & (3) & (4) & (5) & (6) & (7) \\
\hline & \multicolumn{2}{|c|}{ 농어촌 체험 및 생태 관광업 } & (1) & (2) & (3) & (4) & (5) & (6) & (7) \\
\hline & \multicolumn{2}{|c|}{ 관광 공연장업a } & (1) & (2) & (3) & (4) & (5) & (6) & (7) \\
\hline & \multirow{5}{*}{$\begin{array}{l}\text { 관광 레저 } \\
\text { 스포츠시설 } \\
\text { 운영업 }\end{array}$} & 경주장 운영업 & (1) & (2) & (3) & (4) & (5) & (6) & (7) \\
\hline & & 골프장 운영업 & (1) & (2) & (3) & (4) & (5) & (6) & (7) \\
\hline & & 스키장 운영업 & (1) & (2) & (3) & (4) & (5) & (6) & (7) \\
\hline & & 낚시장 운영업 & (1) & (2) & (3) & (4) & (5) & (6) & (7) \\
\hline & & 수상 오락 서비스업 & (1) & (2) & (3) & (4) & (5) & (6) & (7) \\
\hline & $\begin{array}{c}\text { 기타 분류 } \\
\text { 안 된 오락 } \\
\text { 관련 서비스업 }\end{array}$ & 오락 및 관광체험시설 운영 & (1) & (2) & (3) & (4) & (5) & (6) & (7) \\
\hline \multirow{2}{*}{ 카지노업 } & \multicolumn{2}{|c|}{ 외국인 전용 카지노업a } & (1) & (2) & (3) & (4) & (5) & (6) & (7) \\
\hline & \multicolumn{2}{|c|}{ 내국인 출입 카지노업a } & (1) & (2) & (3) & (4) & (5) & (6) & (7) \\
\hline
\end{tabular}

관광산업특수분류 관광핵심산업에 대한 의견을 기입하여 주십시오.

세부 산업의 추가, 산업의 제외(이동), 산업의 세분화 등 구체적으로 기입하여 주십시오. 


\section{II. 관광산업특수분류 상호의존 관광산업}

관광산업특수분류의 상호의존 관광산업입니다. 관광핵심산업에 해당하는 정도를 체크( $\boldsymbol{V})$ 해 주시기 바랍니다.

\begin{tabular}{|c|c|c|c|c|c|c|c|c|c|}
\hline & 구분 & & 관광학 & 업은 & 다 — & 보통 & & 핵심 & \\
\hline & 과과 거므조하거서어 & 상업 및 휴양건물 건설업 & (1) & (2) & (3) & (4) & (5) & (6) & (7) \\
\hline & டО டこலᄇடこ甘 & 수송시설물 건설업(티미널) & (1) & (2) & (3) & (4) & (5) & (6) & (7) \\
\hline & & 관광용지 개발조성 공사 & (1) & (2) & (3) & (4) & (5) & (6) & (7) \\
\hline 관광 건설업 & 관광 토목건설업 & $\begin{array}{l}\text { 관광지, 관광단지 또는 } \\
\text { 관광특구 조경 건설업 }\end{array}$ & (1) & (2) & (3) & (4) & (5) & (6) & (7) \\
\hline & & $\begin{array}{l}\text { 관광 관련 기타 토목 } \\
\text { 시설물 건설업 }\end{array}$ & (1) & (2) & (3) & (4) & (5) & (6) & (7) \\
\hline & 레저용 의복 소매업 & 레저용 의복 소매업 & (1) & (2) & (3) & (4) & (5) & (6) & (7) \\
\hline 관광 및 & $\begin{array}{c}\text { 레저 및 스포츠용품 } \\
\text { 소매업 }\end{array}$ & $\begin{array}{l}\text { 레저 및 스포츠용품 } \\
\text { 소매업 }\end{array}$ & (1) & (2) & (3) & (4) & (5) & (6) & (7) \\
\hline $\begin{array}{l}\text { 레저용품 } \\
\text { 소매업 }\end{array}$ & $\begin{array}{c}\text { 자전거 및 기타 운송장비 } \\
\text { 소매업 }\end{array}$ & $\begin{array}{l}\text { 자전거 및 기타 운송장비 } \\
\text { 소매업 }\end{array}$ & (1) & (2) & (3) & (4) & (5) & (6) & (7) \\
\hline & $\begin{array}{c}\text { 관광용 가방 및 기타 } \\
\text { 가죽제품 소매업 }\end{array}$ & $\begin{array}{l}\text { 관광용 가방 및 기타 가죽 } \\
\text { 제품 소매업 }\end{array}$ & (1) & (2) & (3) & (4) & (5) & (6) & (7) \\
\hline 과광 보험 및 & 여행자 보험업 & 여행자 보험업 & (1) & (2) & (3) & (4) & (5) & (6) & (7) \\
\hline 금융 & 그이배서어 & 여행자 수표 발행 & (1) & (2) & (3) & (4) & (5) & (6) & (7) \\
\hline & ㅁㅇ이밉 & 환전소 & (1) & (2) & (3) & (4) & (5) & (6) & (7) \\
\hline & $\begin{array}{c}\text { 사진기 및 사진용품 } \\
\text { 소매업 }\end{array}$ & $\begin{array}{l}\text { 사진기 및 사진용품 } \\
\text { 소매업 }\end{array}$ & (1) & (2) & (3) & (4) & (5) & (6) & (7) \\
\hline & 게저 미 오자탑 이대어 & 레저장비 임대업 & (1) & (2) & (3) & (4) & (5) & (6) & (7) \\
\hline 레저장비업 & 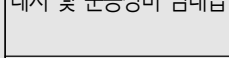 & 운송장비 임대업 & (1) & (2) & (3) & (4) & (5) & (6) & (7) \\
\hline & & 캠핑카 임대업 & (1) & (2) & (3) & (4) & (5) & (6) & (7) \\
\hline & 자동차 임대업 & 관광용 자동차 임대업 & (1) & (2) & (3) & (4) & (5) & (6) & (7) \\
\hline & & 일반 자동차 임대업 & (1) & (2) & (3) & (4) & (5) & (6) & (7) \\
\hline
\end{tabular}

관광산업특수분류 상호의존 관광산업에 대한 의견을 기입하여 주십시오.

관광핵심산업으로 이동되어야 하는 산업에 대해 구체적으로 기입하여 주십시오. 


\section{III. 관광산업특수분류 부분적용 관광산업}

관광산업특수분류의 부분적용 관광산업입니다. 관광핵심산업에 해당하는 정도를 체크( $\boldsymbol{v})$ 해 주시기 바랍니다

\begin{tabular}{|c|c|c|c|c|c|c|c|c|c|}
\hline & 구분 & & 관광핵 & 업은 & 다 — & 보통 & & 핵심 & \\
\hline $\begin{array}{c}\text { 관광 비인증 } \\
\text { 쇼핑업 }\end{array}$ & 관광 비인증 쇼핑업 & 관광 비인증 쇼핑업 & (1) & (2) & (3) & (4) & (5) & (6) & (7) \\
\hline & & 도시간 철도 운송업 & (1) & (2) & (3) & (4) & (5) & (6) & (7) \\
\hline & & 도시내 철도 운송업 & (1) & (2) & (3) & (4) & (5) & (6) & (7) \\
\hline & 부분관광 육상운송업 & 관광보조 버스 운송업 & (1) & (2) & (3) & (4) & (5) & (6) & (7) \\
\hline $\begin{array}{l}\text { 무분놘팡 } \\
\text { 우소언 }\end{array}$ & & 시내외버스 운송업 & (1) & (2) & (3) & (4) & (5) & (6) & (7) \\
\hline & & 택시 운송업 & (1) & (2) & (3) & (4) & (5) & (6) & (7) \\
\hline & ㅂㅂㅂㅂ과과 사잇ㅅㅇㅓ & 수상운송업 & (1) & (2) & (3) & (4) & (5) & (6) & (7) \\
\hline & Tㄴㄴㄴㅇㅇ TO늡ㅂ & 내항.내륙 여객선 운송업 & (1) & (2) & (3) & (4) & (5) & (6) & (7) \\
\hline 부분관광 & 청소년수련원 & 청소년수련원 & (1) & (2) & (3) & (4) & (5) & (6) & (7) \\
\hline 숙박업 & 관광 비인증 모텔업 & 관광 비인증 모텔업 & (1) & (2) & (3) & (4) & (5) & (6) & (7) \\
\hline 부부과과 & 부분관광 음식점업 & 관광 일반음식점업 & (1) & (2) & (3) & (4) & (5) & (6) & (7) \\
\hline 음식점 및 & ㅂㅂ버과과 즈저어 & 비알콜 관광 음료점업 & (1) & (2) & (3) & (4) & (5) & (6) & (7) \\
\hline & Tㄴㄴㄴㅇㅜ Tㅁㅂ & 기타 관광 주점업 & (1) & (2) & (3) & (4) & (5) & (6) & (7) \\
\hline $\begin{array}{l}\text { 부분관광 } \\
\text { 공연장업 }\end{array}$ & 부분관광 공연장업 & 일반 공연시설 운영업 & (1) & (2) & (3) & (4) & (5) & (6) & (7) \\
\hline & & 온라인상 여행정보제공 & (1) & (2) & (3) & (4) & (5) & (6) & (7) \\
\hline 부분관광 기타 & 관광 정보 서비스업 & $\begin{array}{l}\text { 관광지도 및 여행서적 } \\
\text { 출판업 }\end{array}$ & (1) & (2) & (3) & (4) & (5) & (6) & (7) \\
\hline 서비스업 & 전문기술 서비스업 & 통역 서비스업 & (1) & (2) & (3) & (4) & (5) & (6) & (7) \\
\hline & 기타 과과 서비시어 & 온천탕 & (1) & (2) & (3) & (4) & (5) & (6) & (7) \\
\hline & & 그 외 기타 관광서비스업 & (1) & (2) & (3) & (4) & (5) & (6) & (7) \\
\hline
\end{tabular}

관광산업특수분류 부분적용 관광산업에 대한 의견을 기입하여 주십시오.

관광핵심산업으로 이동되어야 하는 산업에 대해 구체적으로 기입하여 주십시오. 


\section{IV. 관광진흥법상 관광사업 반영}

관광진흥법상 관광사업을 반영한 관광산업분류입니다. 관광핵심산업에 해당하는 정도를 체크( $\boldsymbol{\sim})$ 해 주시기 바랍니다.

\begin{tabular}{|c|c|c|c|c|c|c|c|c|c|}
\hline \multicolumn{3}{|c|}{ 구분 } & \multicolumn{3}{|c|}{ 관광핵심산업은 아니다 $\leftarrow$} & \multirow{2}{*}{$\begin{array}{l}\text { 보통 } \\
\text { (4) }\end{array}$} & \multicolumn{3}{|c|}{$\rightarrow$ 관광핵심산업이다 } \\
\hline \multirow{3}{*}{ 관광숙박업 } & \multirow{2}{*}{ 호텔업 } & 소형호텔업 & (1) & (2) & (3) & & (5) & (6) & (7) \\
\hline & & 의료관광호텔업 & (1) & (2) & (3) & (4) & (5) & (6) & (7) \\
\hline & 일반 관광 숙박업 & 일반 야영장업 & (1) & (2) & (3) & (4) & (5) & (6) & (7) \\
\hline $\begin{array}{l}\text { 여행사 및 } \\
\text { 여행보조 } \\
\text { 서비스업 }\end{array}$ & $\begin{array}{c}\text { 관광관련 전문기술 } \\
\quad \text { 서비스업 }\end{array}$ & 관광 사진업 & (1) & (2) & (3) & (4) & (5) & (6) & (7) \\
\hline 전문 및 & 전문휴양업 & 전문휴양업 & (1) & (2) & (3) & (4) & (5) & (6) & (7) \\
\hline 종합휴양업 & 종합휴양업 & 종합휴양업 & (1) & (2) & (3) & (4) & (5) & (6) & (7) \\
\hline
\end{tabular}

\section{V. 기타 의견}

관광산업특수분류 전반에 대해 제언해 주실 사항이 있으시면 기입하여 주십시오.

․ㅗㄴ 조사에 협조하여 주심에 깊이 감사드립니다. 


\section{관광산업특수분류 관광숙박업 요소비중 조사}

안녕하십니까? 귀 사의 무궁한 발전을 기원합니다.

한국문화관광연구원에서는 국내 관광산업의 실태를 파악하고자 각 사업체를 대상으로 사업운영에 있어 관광산업이 차지하고 있는 비중을 조사하고 있습니다. 본 조사의 결과는 국내 관광산업의 규모와 경제 적 기여도를 산출하는 기초 자료로 활용될 예정입니다.

바쁘시고 번거로우시겠지만 잠시만 시간을 내시어 조사에 협조해 주시면 대단히 감사하겠습니다.

응답하신 내용은 통계법 제33조 및 제34조에 의해 비밀이 철저히 보장되며, 반드시 통계작성 목적으 로만 사용하여 귀사에 피해가 가는 일이 없도록 할 것을 약속드립니다.

2020년 8월

연구자: 권태일 연구위원(02-2669-8902, tikwon@kcti.re.kr)

면접원 기입란: 면접원이 기입하는 부분입니다.

\begin{tabular}{|c|c|}
\hline 표본번호 & 업종 \\
\hline & $\begin{array}{ll}\text { (1) 관광 인증 모텔업 (2) 민박업 (3) 게스트하우스 (4) 산림휴양림업 } \\
\text { (5) 레지던스호텔 } & \text { (6) 기타 관광숙박시설 운영업 }\end{array}$ \\
\hline
\end{tabular}

※ 본 설문지는 재무에 관련된 내용으로 구성되어 있으므로, 해당 내용을 잘 파악하고 있는 관리 책임자급 또는 기업 대표님께서 작성해 주시면 감사하겠습니다.

\begin{tabular}{|c|c|c|c|c|}
\hline \multirow{2}{*}{ 작성자 } & 성명 & & 직위 & \\
\cline { 2 - 6 } & e-mail & \multirow{2}{*}{$@$} & $\begin{array}{c}\text { 직통 } \\
\text { 번호 }\end{array}$ & $(\quad)$ \\
\hline
\end{tabular}

※ 2019년 12월 31일 기준으로 작성해 주십시오.

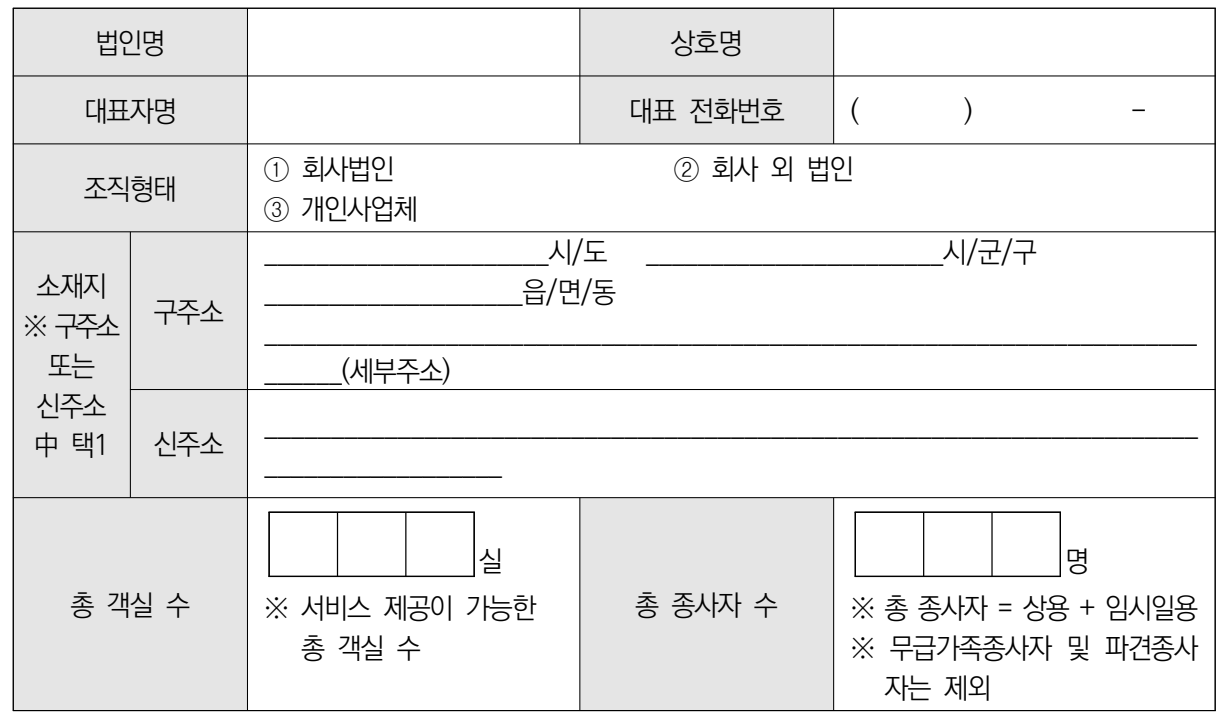


※ 지금부터는 「관광활동」과 관련된 귀사의 현황에 대하여 여쭈어 보겠습니다.

\section{관광산업이란?}

우리나라 통계청에서는 관광산업은 "일상 생활권을 벗어나 이루어지는 쇼핑, 식음료, 숙박, 교통, 위락 등과 관련된 재화와 서비스를 생산하는 단위의 집합”으로 정의하고 있습니다.

자료: 통계청(2012) 관광사업체기초통계조사 품질개선 컨설팅 최종결과보고서: 관광산업 특수분류체계 개선

본 조사에서의 관광활동은 "일상 생활권을 벗어난 고객이 관광 및 여가/휴식의 목적으로 숙박을 하는 행위"로 정의하고 있습니다.

- 관광활동 인정 목적: 관광(단체여행 및 동호회 활동 등 단체관광 포함), 여가/휴식(게임·영화 감상 등 놀이활동)

- 관광활동 불인정 목적: 비즈니스(출장 등), 파티, 이벤트 활동, 시험공부(스터디) 등

\section{I. 매출액 부분}

1. 귀사의 2019년 총 매출액은 얼마입니까?

\begin{tabular}{|c|c|c|c|c|c|c|c|}
\hline \multirow{2}{*}{ 2019년 총 매출액 } & 백억 & 십억 & 억 & 천만 & 백만 & 십만 & - \\
\cline { 2 - 8 } & & & & & & & 원 \\
\hline
\end{tabular}

※ 매출액 $=$ 판매가격 * 판매량

※ 2019년 12월 31일 결산 기준으로 응답해 주십시오.

2, 귀사는 2019년 매출액 중 관광활동에 의한 매출액이 있습니까?

※ 상단의 관광활동에 대한 내용을 자세히 읽어보시고 응답해 주십시오.

(1) 있음 문2-1로 이동

(2) 없음 문3으로 이동

2-1. 귀사의 2019년 총 매출액 중 관광활동과 관련된 매출액 비중은 얼마입니까?

2019년 전체 매출액 中

관광활동 매출액 비중

※ 2019년 총 1 억의 매출액을 올리고, 이 중 관광활동과 관련한 매출액이 5 천만 원인 경우 $50.0 \%$ 로 응답해 주십시오.

※ 응답은 소수점 첫째자리까지 응답해 주십시오.

2-2. 귀사의 2019년 관관활동 매출액 중 내국인과 외국인 매출액 비중은 각각 어떻게 됩니까?

\begin{tabular}{|c|c|c|c|c|c|c|}
\hline \multicolumn{5}{|c|}{ 구분 } & \multicolumn{5}{|c|}{ 비중 } \\
\hline 관광활동 매출액 중 내국인 비중 (A) & & & &. & & $\%$ \\
\hline 관광활동 매출액 중 외국인 비중 (B) & & & &. & & $\%$ \\
\hline 합계 (A+B) & 1 & 0 & 0 &. & 0 & $\%$ \\
\hline
\end{tabular}

※ 2019년 관광활동 매출액 5 천만 원 $(50 \%)$ 중 내국인 대상 매출액이 3천만 원인 경우 $60.0 \%$, 외국인 대상 매출액이 2 천만 원인 경우 $40.0 \%$ 로 응답해 주십시오.

※ 내국인 매출액 비중(A)과 외국인 매출액 비중(B)의 합은 $100 \%$ 가 되어야 함

※ 응답은 소수점 첫째자리까지 응답해 주십시오. 
2-3. 귀사의 2019년 관관활동 매출액 중 단체여행(Package)과 개별여행(FIT) 매출액 비중은 각각 어떻게 됩니까?

\begin{tabular}{|c|c|c|c|c|c|c|}
\hline 구분 & \multicolumn{5}{|c|}{ 비중 } \\
\hline 관광활동 매출액 중 단체여행 비중 (A) & & & &. & $\%$ \\
\hline 관광활동 매출액 중 개별여행 비중 (B) & & & &. & $\%$ \\
\hline 합계 (A+B) & 1 & 0 & 0 &. & 0 & $\%$ \\
\hline
\end{tabular}

※ 2019년 관광활동 매출액 5 천만 원(50\%) 중 내국인 대상 매출액이 3천만 원인 경우 $60.0 \%$, 외국인 대상 매출액이 2천만 원인 경우 $40.0 \%$ 로 응답해 주십시오.

※ 내국인 매출액 비중(A)과 외국인 매출액 비중(B)의 합은 $100 \%$ 가 되어야 함

※ 응답은 소수점 첫째자리까지 응답해 주십시오.

\section{II. 지출액 부분}

3, 귀사의 2019년 총 지출액은 얼마입니까?

\begin{tabular}{|l|l|l|l|l|l|l|c|}
\hline \multirow{2}{*}{ 2019년 총 지출액 } & 백억 & 십억 & 억 & 천만 & 백만 & 십만 & - \\
\cline { 2 - 8 } & & & & & & & 원 \\
\hline
\end{tabular}

※ 지출액이란 관리비, 인건비, 광고비, 영업비 등 서비스 제공을 위해 사용하는 모든 비용을 의미함

※ 2019년 12월 31일 결산 기준으로 응답해 주십시오.

4. 귀사는 2019년 지출액 중 관광활동에 의한 지출액이 있습니까?
(1) 있음 문4-1로 이동
(2) 없음 문5로 이동

4-1. 귀사의 2019년 총 지출액 중 관광활동과 관련된 지출액 비중은 얼마입니까?

\begin{tabular}{|c|l|l|l|l|l|l|}
\hline $\begin{array}{c}\text { 2019년 전체 지출액 中 } \\
\text { 관광활동 지출액 비중 }\end{array}$ & & & & & & $\%$ \\
\hline
\end{tabular}

※ 2019년 총 2천만 원 지출액을 사용하고, 이 중 관광활동과 관련한 지출액이 1천만 원인 경우 $50.0 \%$ 로 응답해 주십시오.

※ 응답은 소수점 첫째자리까지 응답해 주십시오.

\section{III. 관광활동 수요}

5. 매출이나 지출 등을 고려했을 때, 귀사에 관관활동이 얼마나 중요하다고 생각하십니까?
(1) 전혀 중요하지 않다
(2) 중요하지 않다
(3) 보통이다
(4) 중요하다
(5) 매우 중요하다

6. 귀사는 향후 관광활동을 통한 사업을 확대하실 의향이 있습니까?
(1) 전혀 그렇지 않다
(2) 그렇지 않다
(3) 보통이다
(4) 그렇다
(5) 매우 그렇다 


\section{참고. 관광산업특수분류와 한국표준산업분류 연계표}

\section{I. 관광산업특수분류 관광핵심산업}

\begin{tabular}{|c|c|c|c|}
\hline \multicolumn{3}{|c|}{ 관광산업특수분류명 } & 한국표준산업분류명 \\
\hline \multirow{3}{*}{$\begin{array}{c}\text { 관광 } \\
\text { 쇼핑업 } \\
\text { (도매업 } \\
\text { 제외) } \\
\end{array}$} & \multicolumn{2}{|l|}{ 면세점 } & 면세점 \\
\hline & \multicolumn{2}{|c|}{ 외국인전용 관광기념품 판매업 } & 기념품, 관광 민예품 및 장식용품 소매업 \\
\hline & \multicolumn{2}{|l|}{ 관광 인증 쇼핑업 } & 종합 소매업 \\
\hline \multirow{8}{*}{$\begin{array}{l}\text { 관광 } \\
\text { 운수업 }\end{array}$} & \multicolumn{2}{|l|}{ 관광 철도운송업 } & 철도 여객운송업 \\
\hline & \multirow{3}{*}{$\begin{array}{c}\text { 관광 } \\
\text { 도로운송업 }\end{array}$} & 시내순환 관광업a & 시내버스 운송업 \\
\hline & & 전세버스 운송업 & 전세버스 운송업 \\
\hline & & 관광궤도업a & 기타 부정기 여객 육상 운송업 \\
\hline & \multirow{2}{*}{$\begin{array}{c}\text { 관광 } \\
\text { 수상운송업 }\end{array}$} & 관광 유람선업a & $\begin{array}{l}\text { 내항 여객 운송업 } \\
\text { 내륙 수상 여객 및 화물 운송업 }\end{array}$ \\
\hline & & 크루즈업a & 외항 여객 운송업 \\
\hline & \multirow{2}{*}{ 관광 항공운송업 } & 관광 항공 정기운송업 & 항공 여객 운송업 \\
\hline & & 관광 항공 부정기운송업 & 항공 여객 운송업 \\
\hline \multirow{16}{*}{$\begin{array}{l}\text { 관광 } \\
\text { 숙박업 }\end{array}$} & \multirow{5}{*}{ 호텔업 } & 관광 호텔업a & 호텔업 \\
\hline & & 수상관광 호텔업a & 호텔업 \\
\hline & & 한국전통 호텔업a & 호텔업 \\
\hline & & 가족 호텔업a & 휴양 콘도 운영업 \\
\hline & & 호스텔업a & 기타 일반 및 생활 숙박시설 운영업 \\
\hline & \multicolumn{2}{|l|}{ 휴양콘도미니엄업a } & 휴양 콘도 운영업 \\
\hline & \multicolumn{2}{|l|}{ 관광 펜션업a } & 기타 일반 및 생활 숙박시설 운영업 \\
\hline & \multirow{9}{*}{$\begin{array}{c}\text { 일반 관광 } \\
\text { 숙박업 }\end{array}$} & 산림휴양림업 & 기타 일반 및 생활 숙박시설 운영업 \\
\hline & & 게스트하우스 & 민박업 \\
\hline & & 레지던스 호텔 & 기타 일반 및 생활 숙박시설 운영업 \\
\hline & & 관광 인증 모텔업 & 여관업 \\
\hline & & 민박업 & 민박업 \\
\hline & & 외국인 관광 도시민박업a & 민박업 \\
\hline & & 자동차 야영장업a & 기타 일반 및 생활 숙박시설 운영업 \\
\hline & & 한옥체험업 & 민박업 \\
\hline & & 기타 관광 숙박시설 운영업 & $\begin{array}{l}\text { 기타 일반 및 생활 숙박시설 운영업 } \\
\text { 청소년 수련시설 운영업 }\end{array}$ \\
\hline
\end{tabular}




\begin{tabular}{|c|c|c|c|}
\hline \multicolumn{3}{|c|}{ 관광산업특수분류명 } & 한국표준산업분류명 \\
\hline \multirow{5}{*}{$\begin{array}{l}\text { 관광 } \\
\text { 음식점 } \\
\text { 및 } \\
\text { 주점업 }\end{array}$} & \multicolumn{2}{|l|}{ 관광 식당업a } & $\begin{array}{l}\text { 한식 음식점업 } \\
\text { 외국식 음식점업 }\end{array}$ \\
\hline & \multirow{4}{*}{$\begin{array}{l}\text { 관광 } \\
\text { 주점업 }\end{array}$} & 관광 유흥음식점업a & 일반유흥 주점업 \\
\hline & & 관광 극장유흥업a & 무도유흥 주점업 \\
\hline & & 관광 공연장업a & 주점업 \\
\hline & & 외국인전용 유흥음식점업a & 주점업 \\
\hline \multirow{4}{*}{$\begin{array}{l}\text { 여행사 } \\
\text { 및 여행 } \\
\text { 보조 } \\
\text { 서비스업 }\end{array}$} & \multirow{3}{*}{ 여행업 } & 일반 여행업a & 여행사업 \\
\hline & & 국외 여행업a & 여행사업 \\
\hline & & 국내 여행업a & 여행사업 \\
\hline & \multicolumn{2}{|c|}{ 여행보조 및 예약 서비스업 } & 기타 여행보조 및 예약 서비스업 \\
\hline \multirow{2}{*}{$\begin{array}{l}\text { 국제회의 } \\
\quad \text { 업 }\end{array}$} & \multicolumn{2}{|l|}{ 국제회의 기획업a } & 전시, 컨벤션 및 행사 대행업 \\
\hline & \multicolumn{2}{|l|}{ 국제회의 시설업 } & 전시, 컨벤션 및 행사 대행업 \\
\hline \multirow{16}{*}{$\begin{array}{c}\text { 문화, } \\
\text { 오락 및 } \\
\text { 레저 } \\
\text { 스포츠산 } \\
\text { 업 }\end{array}$} & \multirow{2}{*}{$\begin{array}{c}\text { 박물관 및 } \\
\text { 사적지 } \\
\text { 관리 운영업 }\end{array}$} & 박물관 운영업(미술관 포함) & 박물관 운영업 \\
\hline & & 사적지 관리 운영업 & 사적지 관리 운영업 \\
\hline & \multirow{3}{*}{$\begin{array}{c}\text { 식물원, } \\
\text { 동물원 및 } \\
\text { 자연공원 } \\
\text { 운영업 }\end{array}$} & 식물원, 동물원 운영업 & 식물원 및 동물원 운영업 \\
\hline & & 자연공원 운영업 & 자연공원 운영업 \\
\hline & & 기타 관광지 운영업 & 기타 유사 여가관련 서비스업 \\
\hline & \multirow{3}{*}{ 유원시설업 } & 종합유원시설업a & 유원지 및 테마파크 운영업 \\
\hline & & 일반유원시설업a & 유원지 및 테마파크 운영업 \\
\hline & & 기타유원시설업a & 기타 오락장 운영업 \\
\hline & \multicolumn{2}{|c|}{ 농어촌 체험 및 생태 관광업 } & $\begin{array}{l}\text { 청소년수련시설 운영업 } \\
\text { 자연공원 운영업 }\end{array}$ \\
\hline & \multicolumn{2}{|l|}{ 관광 공연장업a } & 공연시설 운영업 \\
\hline & \multirow{5}{*}{$\begin{array}{c}\text { 관광 레저 } \\
\text { 스포츠시설 운영업 }\end{array}$} & 경주장 운영업 & 경주장 및 동물경기장 운영업 \\
\hline & & 골프장 운영업 & 골프장 운영업 \\
\hline & & 스키장 운영업 & 스키장 운영업 \\
\hline & & 낚시장 운영업 & 낚시장 운영업 \\
\hline & & 수상 오락 서비스업 & $\begin{array}{l}\text { 그 외 기타 스포츠시설 운영업 } \\
\text { 기타 수상오락 서비스업 }\end{array}$ \\
\hline & $\begin{array}{c}\text { 기타 분류 안 된 오락 } \\
\text { 관련 서비스업 }\end{array}$ & 오락 및 관광체험시설 운영 & 그 외 기타 분류 안된 오락 관련 서비스업 \\
\hline \multirow{2}{*}{ 카지노업 } & \multicolumn{2}{|c|}{ 외국인 전용 카지노업a } & 기타 사행시설 관리 및 운영업 \\
\hline & \multicolumn{2}{|c|}{ 내국인 출입 카지노업a } & 기타 사행시설 관리 및 운영업 \\
\hline
\end{tabular}




\section{II. 관광산업특수분류 상호의존 관광산업}

\begin{tabular}{|c|c|c|c|}
\hline \multicolumn{3}{|c|}{ 관광산업특수분류명 } & 한국표준산업분류명 \\
\hline \multirow{5}{*}{$\begin{array}{l}\text { 관광 } \\
\text { 건설업 }\end{array}$} & \multirow{2}{*}{ 관광 건물종합건설업 } & 상업 및 휴양건물 건설업 & $\begin{array}{l}\text { 사무·상업용 및 공공기관용 건물 건설업 } \\
\text { 기타 비주거용 건물 건설업 }\end{array}$ \\
\hline & & 수송시설물 건설업(터미널) & 기타 비거주용 건물 건설업 \\
\hline & \multirow{3}{*}{ 관광 토목건설업 } & 관광용지 개발조성 공사 & 지반조성 건설업 \\
\hline & & $\begin{array}{l}\text { 관광지, 관광단지 또는 } \\
\text { 관광특구 조경 건설업 }\end{array}$ & 조경 건설업 \\
\hline & & $\begin{array}{l}\text { 관광 관련 기타 토목시설물 } \\
\text { 건설업 }\end{array}$ & 기타 토목시설물 건설업 \\
\hline \multirow{4}{*}{$\begin{array}{c}\text { 관광 및 } \\
\text { 레저용품 } \\
\text { 소매업 }\end{array}$} & 레저용 의복 소매업 & 레저용 의복 소매업 & $\begin{array}{l}\text { 셔츠 및 블라우스 소매업 } \\
\text { 기타 의복 소매업 }\end{array}$ \\
\hline & $\begin{array}{c}\text { 레저 및 스포츠용품 } \\
\text { 소매업 }\end{array}$ & 레저 및 스포츠용품 소매업 & $\begin{array}{l}\text { 운동 및 경기용품 소매업 } \\
\text { 게임용구, 인형 및 장난감 소매업 }\end{array}$ \\
\hline & $\begin{array}{l}\text { 자전거 및 기타 } \\
\text { 운송장비 소매업 }\end{array}$ & $\begin{array}{l}\text { 자전거 및 기타 운송장비 } \\
\text { 소매업 }\end{array}$ & 자전거 및 기타 운송장비 소매업 \\
\hline & $\begin{array}{l}\text { 관광용 가방 및 기타 } \\
\text { 가죽제품 소매업 }\end{array}$ & $\begin{array}{l}\text { 관광용 가방 및 기타 가죽 } \\
\text { 제품 소매업 }\end{array}$ & 가방 및 기타 가죽제품 소매업 \\
\hline \multirow{3}{*}{$\begin{array}{c}\text { 관광 } \\
\text { 보험 및 } \\
\text { 금융 } \\
\text { 서비스업 }\end{array}$} & 여행자 보험업 & 여행자 보험업 & 손해 보험업 \\
\hline & \multirow{2}{*}{ 금융서비스업 } & 여행자 수표 발행 & 그 외 기타 금융지원 서비스업 \\
\hline & & 환전소 & 그 외 기타 금융지원 서비스업 \\
\hline \multirow{6}{*}{$\begin{array}{l}\text { 레저 } \\
\text { 장비업 }\end{array}$} & $\begin{array}{l}\text { 사진기 및 사진용품 } \\
\text { 소매업 }\end{array}$ & 사진기 및 사진용품 소매업 & 사진기 및 사진용품 소매업 \\
\hline & \multirow{2}{*}{$\begin{array}{l}\text { 레저 및 운송장비 } \\
\text { 임대업 }\end{array}$} & 레저장비 임대업 & 스포츠 및 레크리에이션 용품 임대업 \\
\hline & & 운송장비 임대업 & 기타 운송장비 임대업 \\
\hline & \multirow{3}{*}{ 자동차 임대업 } & 캠핑카 임대업 & 자동차 임대업 \\
\hline & & 관광용 자동차 임대업 & 자동차 임대업 \\
\hline & & 일반 자동차 임대업 & 자동차 임대업 \\
\hline
\end{tabular}




\section{III. 관광산업특수분류 부분적용 관광산업}

\begin{tabular}{|c|c|c|c|}
\hline \multicolumn{3}{|c|}{ 관광산업특수분류명 } & 한국표준산업분류명 \\
\hline $\begin{array}{l}\text { 관광 } \\
\text { 비인증 } \\
\text { 쇼핑업 }\end{array}$ & 관광 비인증 쇼핑업 & 관광 비인증 쇼핑업 & 소매업; 자동차 제외 \\
\hline \multirow{7}{*}{$\begin{array}{l}\text { 부분관광 } \\
\text { 운송업 }\end{array}$} & \multirow{5}{*}{ 부분관광 육상운송업 } & 도시간 철도 운송업 & 철도 여객 운송업 \\
\hline & & 도시내 철도 운송업 & 도시철도 운송업 \\
\hline & & 관광보조 버스 운송업 & 기타 도시 정기 육상 여객 운송업 \\
\hline & & 시내외버스 운송업 & $\begin{array}{l}\text { 시내버스 운송업 } \\
\text { 시외버스 운송업 }\end{array}$ \\
\hline & & 택시 운송업 & 택시 운송업 \\
\hline & \multirow[b]{2}{*}{ 부분관광 수상운송업 } & 수상운송업 & 항만 내 여객 운송업 \\
\hline & & 내항-내륙 여객선 운송업 & $\begin{array}{l}\text { 내항 여객 운송업 } \\
\text { 내륙 수상 여객 및 회물 운송업 }\end{array}$ \\
\hline \multirow{2}{*}{$\begin{array}{l}\text { 부분관광 } \\
\text { 숙박업 }\end{array}$} & 청소년수련원 & 청소년수련원 & 청소년 수련시설 운영업 \\
\hline & 관광 비인증 모텔업 & 관광 비인증 모텔업 & 여관업 \\
\hline \multirow{3}{*}{$\begin{array}{c}\text { 부분관광 } \\
\text { 음식점 } \\
\text { 및 } \\
\text { 주점업 }\end{array}$} & 부분관광 음식점업 & 관광 일반음식점업 & $\begin{array}{l}\text { 한식 음식점업 } \\
\text { 외국식 음식점업 }\end{array}$ \\
\hline & \multirow[t]{2}{*}{ 부분관광 주점업 } & 비알콜 관광 음료점업 & $\begin{array}{l}\text { 커피전문점 } \\
\text { 기타 비알코올 음료점업 }\end{array}$ \\
\hline & & 기타 관광 주점업 & 주점 및 비알콜음료점업 \\
\hline $\begin{array}{l}\text { 부분관광 } \\
\text { 공연장업 }\end{array}$ & 부분관광 공연장업 & 일반 공연시설 운영업 & 공연시설 운영업 \\
\hline \multirow{5}{*}{$\begin{array}{c}\text { 부분관광 } \\
\text { 기타 } \\
\text { 서비스업 }\end{array}$} & \multirow[b]{2}{*}{ 관광 정보 서비스업 } & 온라인상 여행정보제공 & 데이터베이스 및 온라인정보 제공업 \\
\hline & & $\begin{array}{l}\text { 관광지도 및 여행서적 } \\
\text { 출판업 }\end{array}$ & 일반 서적 출판업 \\
\hline & 전문기술 서비스업 & 통역 서비스업 & 번역 및 통역 서비스업 \\
\hline & \multirow[b]{2}{*}{ 기타 관광 서비스업 } & 온천탕 & 욕탕업 \\
\hline & & 그 외 기타 관광서비스업 & $\begin{array}{l}\text { 그 외 기타 달리 분류되지 않은 개인 } \\
\text { 서비스업 }\end{array}$ \\
\hline
\end{tabular}



집필내역

연구책임

권태일 한국문화관광연구원 연구위원: 제1장 제5장, 연구총괄

관광산업특수분류 개정안에 기초한 관광산업통계 생산방안 연구

발행인 김대관

발행처 한국문화관광연구원

서울시 강서구 금낭화로 154

전화 02-2669-9800 팩스 02-2669-9880

http://www.kcti.re.kr

인쇄일 2020년 10월 19일

발행일 2020년 10월 19일

인쇄인 (사)한국장애인이워크협회 일자리사업장

I S B N 978-89-6035-829-493300

DOI https://doi.org/10.16937/kcti.rep.2020.e19 


\section{Production Plan Study of Tourism Industry Statistics Based on the Revised Special Classification of Tourism Industry}

\section{口访占}

아래의 DOl 또는 QR코드를 통해

口. 이보고서를 무료로 다운로드할 수 있습니다

https://doi.org/10.16937/kcti.rep.2020.e19
KWON TAE IL

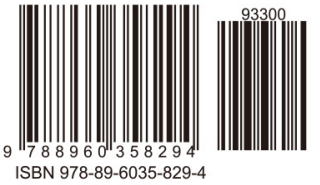

